\title{
LAURA DEGASPARE MONTE MASCARO
}

\section{O Papel da literatura na Promoção e EfetivaÇão DOS Direitos HuManos}

Dissertação apresentada à Faculdade de Direito da Universidade de São Paulo - USP, Departamento de Filosofia e Teoria Geral do Direito para obtenção do Título de Mestre, sob orientação do Prof. Dr. Ari Marcelo Solon.

SÃO PAULO 


\section{LAURA DEGASPARE MONTE MASCARO}

\section{O Papel da literatura na Promoção e efetivação DOS DIREITOS HuMANOS}

Dissertação apresentada à Faculdade de Direito da Universidade de São Paulo - USP, Departamento de Filosofia e Teoria Geral do Direito para obtenção do Título de Mestre, sob orientação do Prof. Dr. Ari Marcelo Solon.

SÃo PAULO 
Mascaro, Laura Degaspare Monte

O papel da literatura na promoção e efetivação dos direitos

humanos./ Laura Degaspare Monte Mascaro. - São Paulo, 2011.

$x ; 215 f$.

Dissertação (Mestrado) - Universidade de São Paulo. Faculdade de Direito. Departamento de Filosofia e Teoria Geral do Direito.

Título em inglês: The role of literature in promoting and effecting human rights.

1. Literatura. 2. Direitos humanos. 3. Liberdade e autenticidade.

4. Formação. 5. Compreensão. 6. Hermenêutica. 7. Discurso e Diálogo.

8. Tradição. 


\section{LAURA DEGASPARE MONTE MASCARO}

\section{O Papel da literatura na Promoção e Efetivação dos Direitos Humanos}

Local de aprovação:

Data de aprovação:

\section{BANCA EXAMINADORA}

Prof. Dr. ARI MARCELO SOLON

InSTITUIÇÃO: FACULDADE DE DiREITO DA UnIVERSIDADE DE SÃo PAUlO

PROF. (A) DR. (A)

InSTITUIÇÃO: FACULDADE DE DiREITO DA UnIVERSIDADE DE SÃo PAUlO

Prof. (A) DR. (A)

INSTITUIÇÃO: 
DEDICATÓRIA

Ao Pedro,

que me ensinou que o caminho do amor é a vida.

Aos meus pais,

que me ensinaram que o caminho da vida são as palavras. 


\section{AgradeCIMENTOS}

Gostaria de expressar os meus sinceros agradecimentos a todos aqueles que de alguma maneira contribuíram no planejamento e execução deste trabalho, permitindo que fosse possível sua conclusão.

\section{Agradeço, particularmente, às seguintes pessoas:}

Ao meu orientador, Professor Ari Marcelo Solon, apanhador no campo de centeio, por ter me ensinado o caminho do verdadeiro logos.

À Professora Claudia Perrone-Moisés, por seu carinho, exemplo e ensinamentos.

Ao Professor Guilherme Assis de Almeida, pela contribuição inestimável a este trabalho.

Ao Professor Antonio Candido, pelo apoio e por ter dito o que muitas vezes não consegui dizer.

À Professora Leyla Perrone-Moisés, por compartilhar seu conhecimento, mesmo que à distância.

Ao Professor Carlos Minchilo, por seu incentivo.

Aos alunos, que me ensinaram que o caminho da compreensão e da transformação é a generosidade.

A Maria Teresa Zavitoski, pela carinhosa amizade e colaboração a esta dissertação.

A Frederico Diehl, por seu apoio e criteriosa revisão deste trabalho.

Aos meus amigos, por estarem sempre ao meu lado e compartilharem minhas alegrias.

E, por fim, a Clarice Lispector, Jorge Luis Borges, Níkos Kazantzákis, Alberto Moravia, Martin Heidegger, Ferreira Gullar, e a tantos outros escritores e poetas, por terem me permitido ver. 
Esta é uma questão não menos pungente porque a levantem com insolência tantos ignorantes ou porque a respondam apologeticamente tantos tolos. A função da poesia é a invocação religiosa da Musa; seu uso é a experiência de uma mistura de exaltação e horror que a presença dela excita. Mas, "hoje"? A função e o uso permanecem os mesmos, apenas sua aplicação se alterou. Outrora, esta fora um alerta ao homem de que deveria viver em harmonia com a familia das criaturas viventes dentre as quais ele nasceu, por obediencia aos desejos da dona da casa; atualmente, trata-se de um lembrete e que desprezou o aviso e virou a casa de cabeça para baixo por meio de voluntariosas experiências na filosofia, na ciência e na indústria, acarretando a ruína para si e para sua família. O termo "hoje" significa uma civilização na qual os principais símbolos da poesia estão desonrados. (...) Na atual civilização, a Lua é desprezada como o satélite apagado da Terra e a mulher, considerada como "contingente auxiliar do estado". Nela, o dinheiro compra quase qualquer coisa, exceto a verdade, e qualquer um, exceto o poeta possuido pela verdade.

Robert Graves (2003, p. 17) 


\section{SUMÁRIO}

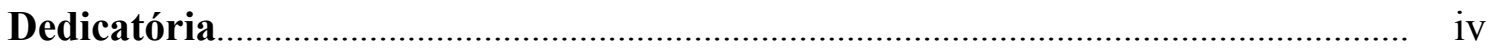

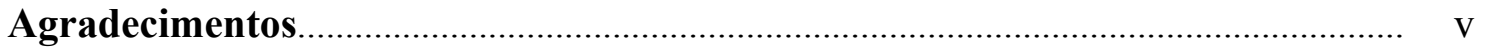

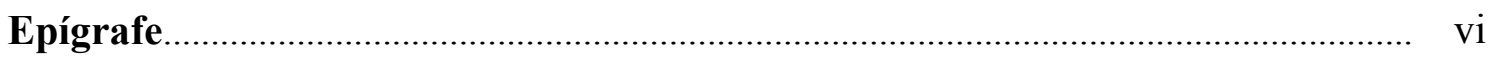

Resumo

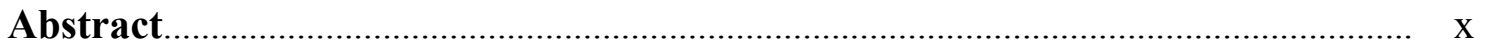

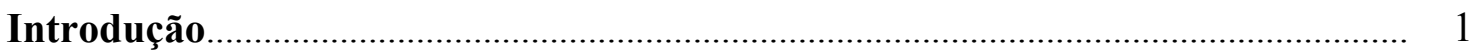

Capítulo I - Um Projeto de Ressignificação dos Direitos Humanos......................... 6

1. O ser humano existente como fundamento dos direitos humanos......................... 12

2. A tarefa de repensar os direitos humanos a partir de uma filosofia da

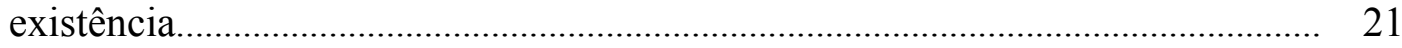

2.1 Liberdade e Igualdade.................................................................................. 33

3. O exemplo literário de $A$ invenção de Morel...................................................... $\quad 50$

4. A promoção e efetivação dos direitos humanos por meio da literatura................. 52

Capítulo II - A Literatura como Fonte de Humanização e Autenticidade............. 60

1. A literatura sob o domínio da opinião pública e a tênue separação da literatura

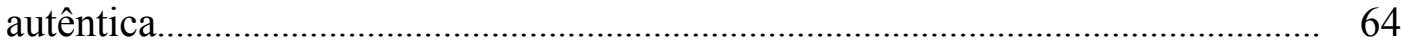

$1.1 \mathrm{O}$ escritor e a obra literária autênticos........................................................... 64

1.2 O público e a interpretação autêntica............................................................ 73

$1.3 \mathrm{O}$ exemplo da Faculdade de Direito.................................................................. 77

2. A literatura na relação do homem como o mundo: construção de uma visão de mundo e de si próprio................................................................................. 82

2.1 Literatura e Humanidade......................................................................... 82

2.2 Visão de Mundo e Horizonte........................................................................... 86

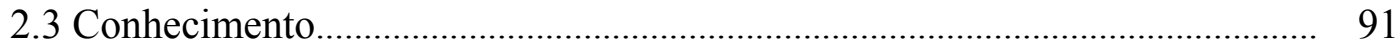

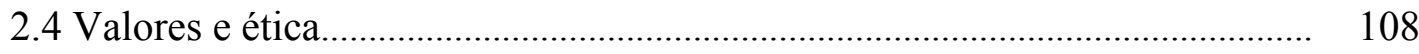


Capítulo III - Em busca do outro ........................................................................... 114

1. A literatura como discurso ................................................................................ 117

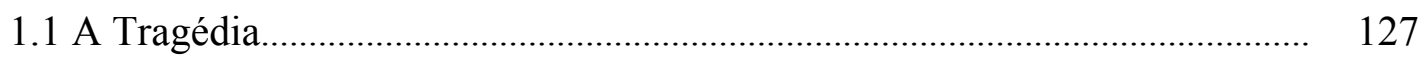

2. A função social da obra literária e do escritor......................................................... 132

3. O escritor e o público......................................................................................... 137

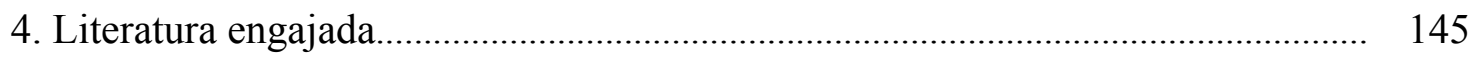

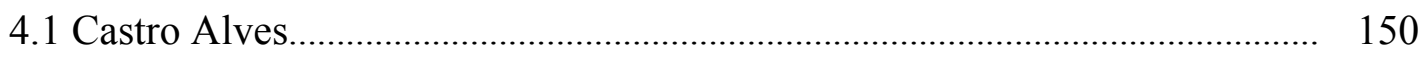

5. O modo de ser dialógico da literatura..................................................................... 153

6. A incapacidade para o diálogo e $O$ Túnel ............................................................ 165

Capítulo IV - A literatura no tempo.......................................................................... 167

1. Temporalidade da Arte e da Literatura................................................................ 174

2. Literatura e escrita como construção e reificação................................................... 176

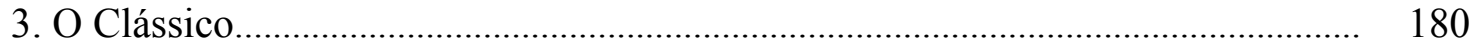

4. Literatura e Tradição.......................................................................................... 184

5. Ocasionalidade versus Permanência: o imediato e o mediato............................... 190

6. Uma crítica ao esquecimento: o direito à memória no Brasil................................ 195

Conclusão

Referências Bibliográficas................................................................................ 209

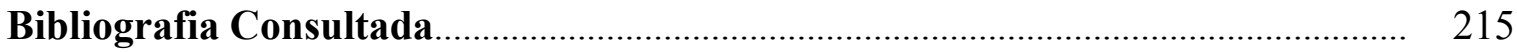




\section{RESUMO}

OBJETIVO: Pretendeu-se, primeiramente, realizar uma proposta de ressignificação dos direitos humanos, interpretando a liberdade e a igualdade a partir da filosofia da existência, de uma forma sensível à essência existencial do homem; traduzindo, assim, a liberdade e a igualdade em autenticidade, cuidado e preocupação com o outro. Em um segundo momento, pretendeu-se analisar o papel da literatura enquanto forma de promoção dos direitos humanos, por sua capacidade formadora e de efetivação dos direitos humanos, permitindo a experiência da liberdade, da autenticidade e do reconhecimento na vida de cada um. MATERIAL E MÉTODOS: Trata-se de trabalho teórico em sentido estrito. O material corresponde a toda a bibliografia que foi percorrida utilizando-se primordialmente o método hermenêutico. Não se pretendeu exaurir o exame da bibliografia de algum autor específico, mas sim se buscou realizar uma abordagem seletiva dos autores e obras, na medida de sua contribuição para o tema e visão propostos. O tema proposto suscita uma abordagem interdisciplinar que muitas vezes encontra-se no limite entre os direitos humanos, a filosofia e a literatura. Por esse motivo, foi necessário percorrer a bibliografia de forma a propiciar uma conexão harmoniosa das idéias trazidas pelos textos, conexão esta que só é possível a partir de uma abordagem dialógica e criativa. Por conta disso, textos teóricos e literários puderam dialogar e se validarem mutuamente. CONCLUSÕES: Conclui-se que a literatura atua por meio de seu modo de ser como um acontecimento e uma experiência que se incorpora na existência dos escritores e leitores como forma: (i) de entendimento do mundo e formação da personalidade autêntica, bem como da ética humana; (ii) de discurso e de diálogo com o outro e com a tradição, através da fusão de horizontes e do compartilhamento de visões de mundo. Deste modo, a literatura possui um papel formador da personalidade, da ética e do modo de ser dos indivíduos muito importantes para que estes sejam capazes de estar no mundo e compartilhá-lo de um modo autêntico, a partir de uma compreensão e apreensão dos direitos humanos que faça sentido em sua existência. 


\begin{abstract}
GOAL: Firstly, this work intended to re-signify human rights, by interpreting freedom and equality from existentialism philosophy grounds, in a way that is sensitive to the existential essence of man; meaning that freedom and equality could be translated in authenticity and concern for others. Secondly, the present work intended to analyze the role of literature in promoting human rights, by its educational capacity, and of effecting these rights, by allowing the experience of freedom, authenticity and recognition into the life of those who come into contact with it. MATERIAL AND METHODS: The present work is strictly theoretical research. The material corresponds to the bibliography read principally under the hermeneutical method. We had no intention of going through the entire work of any specific author, but to accomplish a selective approach of the authors and their work, in terms of their contribution to the theme and perspective here adopted. The proposed theme raises an interdisciplinary approach which many times can find itself at the frontier between human rights, philosophy and literature. For this reason it has been necessary to examine the bibliography in a manner that allows a harmonious connection between the ideas brought by the texts, only possible by means of a creative and dialogical approach. Thus, theoretical and literary texts could dialogue and validate themselves mutually. CONCLUSIONS: We could conclude that literature acts by its way of being as an event and experience that is incorporated in the existence of writers and readers, as a way: (i) of understanding the world and building authentic personality and human ethics; (ii) of discourse and dialogue with another and with tradition, by the fusion of horizons and sharing of world views. Therefore, literature plays an important role in forming personality, ethics and the way of being of individuals, so that people are able to be-in- the-world and share it in an authentic manner, by allowing the comprehension and understanding of human rights in a familiar way, which makes sense in their existence.
\end{abstract}




\section{INTRODUÇ̃̃O}

O Papel da literatura na Promoção e Efetivação dos DiReitos Humanos 
A temática da linguagem e da literatura é de extrema importância para se pensar criticamente o direito na atualidade e efetivá-lo. A filosofia do direito se depara com o desafio de uma produção intelectual que busque promover e efetivar os direitos positivados com base não só na relação normativa, mas em seu conteúdo axiológico que contemple as necessidades humanas. Esse mesmo movimento é seguido pelos direitos humanos, que, após sua positivação - que trouxe não os únicos possíveis direitos do homem, mas sim os direitos do homem histórico, tal como esse se configurava na mente dos redatores da Declaração de Direitos do Homem - encontram-se em um momento de promoção e de efetivação de sua aplicação. Todavia, essa efetivação pode acontecer em diversas esferas, inclusive pela vida de cada um dos seres humanos contemplados por esses direitos e em suas formas de atuação na sociedade, através de um conceito amplo de ação política.

Nesse sentido, a Declaração Universal dos Direito Humanos não é dirigida exclusivamente aos Estados, mas sim a todos os indivíduos e a todas as entidades da sociedade, rompendo com a divisão entre Estado e sociedade civil erigida pelos direitos humanos do homem burguês na Revolução Francesa. Com isso, confiam que a Declaração possa ter como principal propósito a educação dos indivíduos e das instituições em direitos humanos, tornando-se um instrumento que estabelecesse seus princípios.

Assim, estabelecer que todos os seres humanos têm direito à educação não é suficiente se não delinearmos o espírito dessa educação. Para tanto, devemos recorrer à própria Declaração que, aponta para o desenvolvimento do ser humano em primeiro lugar, fortalecendo-se sua personalidade, o respeito aos direitos humanos e às liberdades fundamentais.

Tendo isso em mente, o trabalho se propõe, em primeiro lugar, a realizar uma proposta de interpretação da liberdade e da igualdade que regem os direitos humanos, tendo sido positivadas logo no artigo $1^{\mathrm{o}}$ da Declaração Universal dos Direitos Humanos, por meio de uma filosofia da existência ${ }^{1}$. Isso porque a filosofia do direito precisa olhar além do conceito de sujeito de direito herdado do positivismo jurídico para que possa (re)pensar e ressignificar o direito e a justiça. Dessa maneira, introduzir a questão de quem nós somos na e para a filosofia do direito é crucial (CHUEIRI, 2004, p. 61).

\footnotetext{
${ }^{1}$ As teorias de Martin Heidegger, Hans-Georg Gadamer (especialmente sua abordagem hermenêutica de Verdade e Método) e Hannah Arendt (partindo, em especial, da obra A condição Humana) servirão de guia para a reflexão aqui pretendida.
} 
Faremos, portanto, uma proposta de ressignificação desses direitos, sendo que só há direito quando ele se aplica e sua aplicação atende ao horizonte compreensivo, temporal e histórico (MAMAN, 2003, p.108). Somente a partir do diálogo com a tradição dos direitos humanos que nos fala, principalmente, por meio da Declaração Universal dos Direitos Humanos é que poderemos realizar uma interpretação atenta à passagem do tempo e à contingência humana.

Desse modo, a validade dos direitos humanos e, conseqüentemente, sua efetividade, somente serão possíveis a partir da superação da distância do tempo através de uma atualização conforme a sensibilidade do presente. Isso coloca o intérprete mais próximo dos direitos humanos (MAMAN, 2003, p. 110), que serão recriados por cada intérprete e se farão presentes em todos os tempos. Somente assim sua perenidade e universalidade serão garantidas, acompanhando o movimento histórico humano.

Repensar o passado e a tradição que fala por meio desses direitos e, a partir de certo desprendimento, conferir aos direitos humanos um projeto de sentido adequado ao ser humano existente são, em si, formas de exercer a liberdade humana a caminho de uma ética mais autêntica e adequada aos homens de nosso tempo.

A questão que deverá surgir a partir desse empreendimento hermenêutico é acerca do impacto que a interpretação realizada causa na forma como se promove os direitos humanos em questão. De fato, em decorrência do preceituado no parágrafo pragmático da Declaração Universal dos Direitos Humanos, a interpretação proposta nos conduzirá ao entendimento do espírito da educação como formação (bildung); o que implica compreender a promoção dos direitos humanos de uma forma integrada à vida dos indivíduos, ao seu caminho, à sua autenticidade e à sua forma de compreensão e atuação no mundo, quer no exercício da vita contemplativa, quer no exercício da vita activa. Assim, a promoção por meio da formação consiste em uma busca ética, mais do que doutrinária ou educativa em um sentido estrito.

Vale reiterar, portanto, a relevância do trabalho em prol dos direitos humanos $a$ fortiori, ou seja, sua promoção e efetivação posteriormente à positivação internacionalmente reconhecida (BOBBIO, 2004). E conforme se propõe no presente trabalho, a literatura assume um papel não absoluto ou conclusivo, é claro, mas muito importante para a afirmação desses direitos na vida de cada pessoa, uma vez que "uma nova forma de (re)pensar o direito (no campo da filosofia do direito) precisa levar em conta a imaginação literária, salientando a cumplicidade entre direito e literatura. Filosofia 
do direito e teoria geral do direito não podem apenas pressupor, mas também comprometerem-se com os cruzamentos e entrelaçamentos que estão na base de seus problemas" (tradução livre da autora) (CHUEIRI, 2004, p. 60).

Cabe ressaltar, preliminarmente, que trabalharemos em um primeiro momento com um conceito de literatura bastante amplo, extraído do texto de Antonio Candido intitulado $O$ direito à literatura.

Contudo, à medida que as questões forem sendo desenvolvidas na dissertação, serão explorados aspectos da literatura complementares a esse conceito, mesmo porque, importa mais a nós descrever a forma como a literatura acontece e se insere no mundo da existência, do que fixar um conceito fechado de literatura. A literatura, portanto, por ser produto humano, também é um conceito em formação à medida de sua existência. Assim, a determinação de sua valência ontológica própria somente pode acontecer na medida em que formos trabalhando com esse conceito e testando seus limites.

Nesse sentido, uma das propostas desta dissertação é analisar como a literatura é em si uma experiência compreensiva e a forma como colabora para a construção de um horizonte de entendimento do mundo muito mais fundamental do que a conceituação do mundo e a cognição proporcionada pelas ciências.

Pretende-se, assim, demonstrar como a literatura forma e humaniza não somente quando é uma literatura engajada ou social, mas principalmente quando a representação nela realizada consegue operar um crescimento no mundo. A partir dessa representação, tanto o escritor produz uma obra autêntica e exerce sua autenticidade, quanto o leitor tem a oportunidade, trazendo essa representação à vida, de recriá-la autenticamente e conhecer a si mesmo, na medida em que vive a experiência da literatura e é interpelado por aquela representação.

A literatura, ainda, pode ter o papel de veicular discursos que legitimam e fazem compreender as idéias dos homens e povos que os proferem. Assim, ela traz a surpresa e a inovação que carregam todos os homens enquanto seres únicos e originais. Neste âmbito, a literatura pode proporcionar e manter espaços políticos livres e democráticos. Uma vez garantida, todos os homens podem ter acesso a ela e dela se valerem para revelarem sua existência e sua singularidade. A literatura vem a serviço das pessoas isoladas do convívio social, ou das esferas políticas oficiais, correndo por fora e acima, disseminando discursos. A própria literatura pretende ser investigada, aqui, como um espaço político independente. 
Entendemos, ainda, que a outra face do discurso, essencial à sua realização plena, é o diálogo que ocorre na compreensão de uma obra literária e que proporciona o reconhecimento e a fusão de horizontes do leitor com a obra e com o outro.

Por fim, pretendemos discutir a dimensão que envolve o modo de ser temporal da literatura. Assim, mostraremos que a literatura não paira acima e fora do tempo, mas sim dentro dele, como parte da história e como construção humana. O fato de a literatura ser uma construção humana que tende a ser perene leva-a a transcender a existência finita dos homens e a situação originária em que foi criada, passando, desse modo, a integrar o horizonte móvel da tradição. Dialogamos com a tradição que fala por meio da literatura e assim podemos projetar nosso futuro e nossa liberdade de maneira enraizada, com o conhecimento do passado, construindo nossa própria visão sobre ele e, assim, nos libertando.

Assim, buscaremos concluir, na esteira do raciocínio que investiga a literatura como fonte do reconhecimento do outro e como possível estímulo para a pré-ocupação conosco e com o outro, como se dá o simultâneo abandono de uma reflexão ética no espaço público e em muitos espaços privados, e a perda do hábito literário enquanto fonte primária da educação humanista e sensível (MATOS, 2006). Desse modo, como é possível pretender que a educação atue como fonte de promoção dos direitos humanos sem que esta inclua a literatura em toda sua dimensão desveladora, dialógica e temporal? 
Capítulo I

Um Projeto de RessignificaÇão dos Direitos Humanos 


\section{Canção da Infância}

Quando a criança era criança,

Era o tempo para essas perguntas:

Por que eu sou eu, e não você?

Por que estou aqui, e não lá?

Quando o tempo começou, e onde o espaço termina?

Não é a vida sob o sol apena um sonho?

Não é o que vejo, ouço e cheiro somente uma ilusão de um mundo anterior ao mundo?

Dados os fatos do mal e das pessoas.

O mal realmente existe?

Como pode ser que eu, quem eu sou,

Não existia antes de eu vir a ser,

e que, algum dia, quem eu sou não será mais quem eu sou?

(tradução livre da autora) ${ }^{2}$.

(HANDKE, 1987).

Proclamada pela Assembléia Geral das Nações Unidas em 10 de dezembro de 1948, em Paris, a Declaração Universal dos Direitos Humanos declarou, pela primeira vez em nível internacional, como um padrão comum de realização para todos os povos e nações, os direitos humanos e liberdades fundamentais; noções até então difusas, tratadas apenas de maneira não-uniforme, em declarações e legislações nacionais (ALVES, 1994).

\footnotetext{
${ }^{2}$ Do poema Song of Childhood (Lied Vom Kindsein) que Peter Handke escreveu para o filme Asas do Desejo (Der Himmel über Berlin) de 1987.
} 
A Declaração Universal dos Direitos Humanos, resultante da percepção política de que as atrocidades do totalitarismo representavam uma ruptura inédita da tradicional preocupação ética com o bom governo, assinala o início desse direcionamento no campo dos valores no plano internacional. Seria, portanto, a primeira resposta jurídica da comunidade internacional à constatação de que o direito ex parte populi de todo ser humano à hospitalidade universal (negado em larga escala, na prática, pela existência de refugiados, apátridas, deslocados, campos de concentração e pelo genocídio) só seria possível se o direito a ter direitos tivesse uma tutela internacional reconhecida do ponto de vista da humanidade. Foi assim que começou efetivamente a ser restringida, em matéria de direitos humanos, a razão de Estado e corroída a competência reservada da soberania dos governantes (ALVES, 1994).

Essa emergência dos direitos humanos nas relações internacionais após a Segunda Guerra Mundial é tida como uma verdadeira revolução, visto que teria colocado o indivíduo no primeiro plano do direito internacional, sendo que antes esse domínio era reservado exclusivamente aos Estados. Norberto Bobbio (2004, p. 51) percebe que a Declaração Universal representa o início de um processo pelo qual os direitos humanos deixam de ser direitos do cidadão nacional para se tornarem direitos do "cidadão do mundo". Bobbio (2004, p. 69), ainda, em suas reflexões político-filosóficas a respeito do mundo moderno identifica na crescente importância atribuída ao tema dos direitos humanos o principal sinal de progresso moral da humanidade ${ }^{3}$.

O processo de asserção dos direitos humanos passou por algumas etapas. A primeira, de proteção internacional (internacionalização) desses direitos, deu-se com a fase legislativa de elaboração dos instrumentos internacionais de proteção (Declarações Universal e Americana de 1948), também marcada pela gradual afirmação da capacidade de agir dos órgãos de supervisão internacionais e pela cristalização da capacidade processual internacional dos indivíduos. A segunda etapa consistiu na passagem da internacionalização à globalização (I Conferência Mundial, de Teerã, 1968) dos direitos humanos. Da globalização passou-se à indivisibilidade, no período que se estende da I à II Conferência Mundial de Direitos Humanos (1968-1993), que constitui a terceira etapa, da aceitação da indivisibilidade dos direitos humanos, com a implementação dos tratados e instrumentos de proteção (em níveis global e regional), tidos como essencialmente complementares. Além disso, pode-se ainda mencionar uma quarta fase, que seria a de

\footnotetext{
${ }^{3} \mathrm{O}$ conceito de "progresso moral da humanidade" será discutido mais adiante no presente trabalho.
} 
onipresença dos direitos humanos, tendo em vista que os direitos humanos permeiam todas as áreas da atividade humana e o quotidiano da vida de cada um (ALVES, 1994). É nessa quarta fase que procuraremos lançar foco no presente trabalho: veremos que a atuação da literatura é costurada na formação, nas experiências e na visão de mundo das pessoas, de forma a fazer de suas vidas a própria efetivação dos direitos humanos.

Agora, relativamente ao problema do fundamento dos direitos humanos, vejamos o que Bobbio (2004, p. 36) apresenta. Argumente ele que esse não é um problema de direito positivo, mas sim de direito racional ou crítico. $\mathrm{Na}$ verdade, encontrar fundamentos ou aduzir motivos para justificar a escolha por um determinado direito é um meio adequado pra obter para eles um mais amplo reconhecimento. Por isso, por tempos foi sustentada uma idéia de que existiria um fundamento absoluto para todos os direitos humanos, sendo que diante desse fundamento irresistível a mente se dobraria necessariamente. Esse pensamento foi comum durante séculos para os jusnaturalistas, que supunham ter colocado certos direitos acima da possibilidade de qualquer refutação, derivando-os diretamente da natureza humana. No entanto, para Bobbio (2004, p. 37), toda busca do fundamento absoluto hoje é infundada.

Bobbio (2004, pp. 35-44) elabora alguns argumentos que sustentam ser ilusória e inalcançável a busca por um fundamento absoluto dos direitos humanos. Em primeiro lugar, "direitos humanos" é uma expressão muito vaga, sendo que as definições são tautológicas na maioria das vezes. Além disso, quando se empregam termos avaliativos, com referência ao conteúdo, esses são interpretados de modo diverso conforme a ideologia assumida pelo intérprete. Essas contradições vêm à tona no momento da aplicação dos conceitos. Os valores últimos fundamentos dos direitos humanos não possuem em si uma justificativa - o que se faz é assumi-los. Assumir implica renúncias recíprocas, uma obra de conciliação, em que entram em jogo preferências pessoais, opções políticas e orientações ideológicas.

Os direitos humanos constituem, ainda, uma classe variável. O elenco dos direitos humanos modificou-se e continua a se modificar, com a mudança das condições históricas. Isso provaria que não existem direitos humanos por natureza. Além de tudo, a classe dos direitos humanos é também muito heterogênea. Entre os direitos compreendidos na própria Declaração Universal dos Direitos Humanos há pretensões muito diversas entre si e até, em algumas situações concretas, incompatíveis. As razões que valem para sustentar algumas pretensões não valem para sustentar outras; por esse motivo, para Bobbio (2004, p. 39), 
seria muito mais adequado falar em fundamentos dos direitos humanos conforme o direito cujas boas razões desejam-se defender.

$\mathrm{Na}$ época em que a Declaração Universal dos Direitos Humanos estava sendo elaborada, a UNESCO realizou uma pesquisa com os principais intelectuais do mundo para descobrir qual seria o fundamento filosófico dos direitos humanos. Como não houve nenhum consenso, os estudiosos que editaram e interpretaram os resultados da pesquisa ficaram convencidos de que a questão filosófica na Declaração Universal dos Direitos Humanos não deve atingir um consenso doutrinário, mas antes deve atingir um acordo em relação aos direitos e às ações para a promoção e defesa dos direitos, que podem ser justificadas a partir de embasamentos doutrinários completamente divergentes (MORSINK, 1999, p. 301).

Acreditamos, contudo, ser importante que essa questão não seja encoberta pelo véu do esquecimento, sempre se discutindo filosoficamente, e não dogmaticamente, a visão do humano que embasa os direitos humanos, como também a forma como se dará sua aplicação e efetivação. É legítimo, portanto, questionar se a fundamentação dos direitos humanos que tem sido buscada não parte de uma visão dos seres humanos e de sua essência que permanece conectada a uma visão subjetivista e cartesiana dos homens.

Reconhecemos que a questão do fundamento dos direitos humanos é extremamente sensível e, por conseguinte, procuraremos abrir espaço para a reflexão, sem a pretensão de se chegar a uma resposta definitiva, a partir da discussão filosófica acerca desse fundamento e de seus impactos na significação, promoção e efetivação dos direitos humanos.

A mudança da perspectiva na fundamentação dos direitos humanos, conforme veremos, a partir da comparação dos direitos humanos definidos na Revolução Francesa (MARX, 1975) e dos direitos humanos declarados após os adventos totalitaristas da Segunda Guerra Mundial (BOBBIO, 2004; LAFER; 1988; MORSINK, 1999), relaciona-se com o modo com o homem passou a relacionar-se com a verdade e com o mundo ao longo do tempo (HEIDEGGER, 2008c).

Evidentemente que o modo de ser do ser humano é histórico e, portanto, contempla a cultura e os valores que se modificam, inclusive em virtude de rupturas periódicas com a tradição e de tentativas de repensar esta tradição. Nesse sentido é que os direitos humanos são uma classe mutável, derivados de escolhas contextuais. Por conta disso, um elenco de valores positivados em dado momento histórico passa por diversas crises de significação 
ao longo do tempo e do processo que leva à sua realização plena, mesmo porque esse processo pode ser bastante longo e sempre está sendo reiterado ou reconstruído.

Todavia, não se deve relegar a questão da fundamentação dos direitos humanos à posição de tabu, devendo ser retomada a cada tempo de modo filosófico, mesmo que não seja possível alcançar uma fundamentação definitiva. A discussão acerca da fundamentação é importante para que a tarefa hermenêutica possa ser cumprida, e para que ocorra uma promoção dos direitos humanos sensível ao presente.

O trabalho buscará, portanto, neste primeiro capítulo propor um repensar da tradição dos principais valores que regem os direitos humanos, em especial a liberdade e a igualdade, a partir de uma filosofia da existência.

Relativamente à visão do humano, a fenomenologia existencial servirá de guia para a reflexão aqui pretendida, tendo em vista que oferece uma proposta para a difícil questão de como se fundamentar direitos humanos com base em um ser humano histórico e contingente.

Em um segundo momento, este capítulo se propõe a repensar o passado e a tradição que carregam esses direitos e conferir aos direitos humanos um projeto de sentido adequado ao ser humano existente. Explicar-se-á, ainda, que essa própria ressignificação é uma forma de exercer a liberdade humana a caminho de uma ética mais autêntica e adequada aos homens de nosso tempo; que pode contribuir, portanto, para a superação da crise de significação em que se encontram os valores dos direitos humanos na atualidade, uma crise que prejudica inclusive a sua exeqüibilidade. 


\section{O SER HUMANO EXISTENTE COMO FUNDAMENTO DOS DIREITOS HUMANOS}

A filosofia do direito é um dos principais caminhos pelos quais pode ser realizar a busca pelo fundamento dos direitos humanos, enquanto atenta para o conteúdo axiológico dos direitos positivados. Para Martin Heidegger, filosofar é transcender, significando um reiterado perguntar-se sobre o ser do ente. O filosofar pergunta sobre aquilo que já compreendemos (pré-compreendemos). Assim, abandonar a investigação pelo fundamento dos direitos humanos seria deixar-se tomar pelas insinuações da mais tenaz opositora da filosofia: a suposta auto-evidência das coisas. A investigação filosófica, ao contrário da científica $^{4}$, busca entender o ente em sua totalidade, busca o ser do ente (HEIDEGGER, 2008b, p. 232).

A existência de todas as instituições de que fazemos parte, enquanto Estado ou indivíduo, implicam o compartilhamento de uma cultura e de uma linguagem filosófica, comprometendo-se a tornar possível, por meio da educação, em primeiro lugar, o acesso a essa linguagem e a essa cultura. Todos os Estados que aderem às cartas dessas instituições, como, por exemplo, à Carta das Nações Unidas (1945), se comprometem a reconhecer e a difundir certa filosofia do direito, e, nesse caso, dos direitos humanos. Fazer parte dessas instituições é um ato filosófico que nos engaja filosoficamente com a filosofia. Resta saber, contudo, de que forma essa filosofia será pensada: de maneira dogmática ou autenticamente filosófica (DERRIDA, 2002)

Quaisquer questões relacionadas aos direitos humanos, quer sejam relativas à ecologia, à bioética, à inseminação artificial, de direito doméstico ou internacional, sempre tocam na relação do eu com o outro, nos valores de sujeito e objeto, de subjetividade, de identidade, de pessoalidade. Assim, é impossível dissociar a discussão dos direitos humanos da filosofia. Os direitos humanos dependem da filosofia e não somente dos progressos científicos e tecnológicos, devendo ser promovida uma política do pensamento que não se submeta nem ao positivismo nem ao cientificismo, sequer ao epistemologismo; e que redescubra, com base em novos desafios, na relação do pensamento com a ciência,

\footnotetext{
${ }^{4}$ Uma ciência do ente na totalidade é essencialmente impossível. A ciência é conhecimento do ente e não do ser e sempre conhecimento do ente no sentido de uma área demarcada e não do ente na totalidade. Nem o ser como tal e nem o ente na totalidade como tal, nem a conexão interna entre ser e ente são jamais acessíveis a uma ciência ou a todas elas em conjunto. O fato é que somente com base nessa inacessibilidade e nesse círculo assim limitado é que a ciência pode empreender suas investigações.
} 
mas também com a religião, bem como com o direito e com a ética, a experiência do respeito mútuo, sempre em conjunto com a autonomia irredutível.

Os recursos direcionados ao ensino e à pesquisa em geral dirigem-se - por ser lucrativo, útil e urgente - à ciência aplicada, à técnica econômica, ou até mesmo à ciência militar. Mas quanto mais esse imperativo se impõe, muitas vezes visando ao desenvolvimento, mais a filosofia torna-se urgente, inclusive para a crítica à própria filosofia, que, tantas vezes, em nome do positivismo técnico, econômico, militar, ou mesmo em nome do pragmatismo ou realismo, tende a reduzir o campo e as chances de uma filosofia autêntica, aberta e sem limite (DERRIDA, 2002).

Todavia, ainda pode-se perguntar se a investigação pelo fundamento último dos direitos humanos já não foi anteriormente empreendida. De fato, diversas reflexões nessa temática já foram realizadas, antes mesmo de existir o conceito de direitos humanos como o conhecemos hoje. Contudo, tendo em vista que essa investigação deve seguir o caminho da filosofia, deve-se ter em mente que na filosofia nenhum resultado pode ser registrado como definitivo, sendo que o caminho importa mais do que o destino, e por essa razão ela também nunca se torna obsoleta. Segundo Heidegger (2008b, p. 241):

\begin{abstract}
o trabalho científico de alguém sempre pode ser fundamentalmente defendido por um outro; as descobertas científicas de alguém também poderiam ter sido feitas por um outro. Isso nunca se dá dessa forma na filosofia; cada um é, nesse caso, um todo único. Por isso o filosofar só se torna vivo e efetivo quando é uma vez mais desperto por outros de maneira originária e autônoma e, nesse sentido, repetido. Quando é autêntica, porém, a repetição renovadora nunca é uma mera cópia.
\end{abstract}

Por conseguinte, a investigação filosófica pelo fundamento dos direitos humanos deve ser renovada sempre de maneira autêntica e viva, sabendo-se que nunca se chegará a um resultado, mas que a filosofia continuará a sua busca na existência de outros filósofos.

De acordo com Fábio Konder Comparato (2006, p. 457), foi sobre a concepção medieval de pessoa que se iniciou a elaboração do princípio da igualdade essencial de todo ser humano, não obstante a miríade de diferenças individuais e grupais, de ordem biológica ou cultural. Essa igualdade de essência da pessoa forma o núcleo do que se veio denominar, nos tempos modernos, direitos humanos. Seriam, assim, direitos comuns a toda espécie humana, resultantes de sua própria natureza, não sendo meras criações do poder político. 
Talvez devêssemos recorrer à própria Declaração Universal dos Direitos Humanos para nos elucidar como era vista a fundamentação dos direitos humanos naquele dado momento. Acerca do Preâmbulo e do artigo $1^{\circ}$ da Declaração Universal dos Direitos Humanos podemos fazer algumas considerações.

Em primeiro lugar fica claro que, independentemente das orientações ideológicas dos elaboradores da Declaração Universal dos Direitos Humanos, todos concebiam os direitos humanos como algo inerente aos seres humanos; e não como algo atribuído em virtude de motivos estranhos à humanidade, como as convenções sociais, atos de governos, ou decisões tomadas por parlamentos ou cortes (MORSINK, 1999, pp. 282-284).

Ao mesmo tempo em que é verdade que os filósofos jusnaturalistas dos séculos XVII e XVIII presumiram ter encontrado uma base sólida para uma moralidade universal e, ao mesmo tempo, secular, o secularismo envolvido tratava-se de uma mistura onde a natureza e a razão ainda estavam próximas do Deus de onde emanavam. Embora a Declaração Universal dos Direitos Humanos não faça referência nem a Deus ou à natureza, isso não significa que a Declaração não seja baseada em noções iluministas de moralidade (MORSINK, 1999, pp. 282-284).

A maioria dos elaboradores da Declaração sentiu-se à vontade para abdicar da referência à natureza no artigo $1^{\mathrm{o}}$ somente porque as palavras inalienável, inerente e nascem ainda ancoravam os direitos que proclamavam na natureza humana. Todavia, é evidente que como a palavra natureza ou a expressão natureza humana não foram utilizadas na Declaração, o título Direitos Humanos é muito mais adequado ao texto do que a expressão direitos naturais. A nova denominação cumpre o mesmo papel, sem a carga metafísica extra que vem vinculada ao discurso dos direitos naturais (MORSINK, 1999, pp. 282-284).

Uma das conseqüências da não utilização da palavra natureza seria de que não podemos abordar algumas palavras-chave do Iluminismo (inalienável, inerente, nascimento) dentro da categoria estrita da tradição racionalista ocidental. Os elaboradores da Declaração vinham dos mais variados tipos de tradição ideológica e filosófica e, mesmo assim, nenhum deles pensava que os direitos humanos deveriam ser atrelados a qualquer característica específica ou grupo de características. A razão e a consciência seriam, antes, para os declarantes, meios pelos quais podemos apreender que as pessoas possuem direitos humanos. E esse conhecimento é que nos deveria fazer agir com espírito de fraternidade em relação ao outro (MORSINK, 1999, pp. 296-302). 
Existem, portanto, duas formas de se olhar para a expressão razão e consciência, uma do domínio do ser (essencialmente, não ontologicamente) e outra no domínio do saber. A primeira forma faz da consciência e da razão atributos essenciais para um membro da família dos seres humanos; não os apresentar torna esse pertencimento questionável. Essa, portanto, é a visão essencialista da natureza humana, que considera razão e consciência a essência do que significa ser humano. Nessa visão, sempre existirá o risco de haver um regime que obste as pessoas de se tornarem membros da humanidade por não raciocinarem "propriamente" ou por suas consciências não serem "como deveriam", que era justamente a forma como os nazistas racionalizavam o holocausto. Assim, é importante que não se interprete a Declaração de 1948 de uma forma estritamente essencialista. A melhor forma de se interpretar o artigo $1^{\circ}$ da Declaração seria a partir do prisma ontológico e epistemológico (MORSINK, 1999, pp. 296-302).

Nessa segunda forma de leitura, razão e consciência aparecem como formas, modos de se perceber que precisamos estar atentos e abertos para o outro com espírito de fraternidade. São formas com que desvelamos a ética contida nos artigos da Declaração Universal dos Direitos Humanos (MORSINK, 1999, pp. 296-302).

Tanto o secularismo como o não essencialismo demonstram que os declarantes de 1948 não seguiram cegamente o precedente iluminista, mas seguiram, em alguma medida, seu próprio curso. Por conseguinte, a mera crítica ao Iluminismo de maneira alguma invalida a Declaração Universal dos Direitos Humanos. Os críticos que interpretam os artigos da Declaração de forma estritamente essencialista ou racionalista empreendem uma interpretação muito limitada do documento (MORSINK, 1999, pp. 296-302).

Uma forma de se escapar à fórmula essencialista, é, conforme propusemos, investigar como a liberdade e a igualdade dos seres humanos podem ser vistas de uma perspectiva em grande medida existencialista. Nesse sentido, a investigação do fundamento dos direitos humanos internacionalmente enunciados na Declaração Universal dos Direitos Humanos, tendo como valor-fonte o próprio ser humano, que teria como base a concepção de dasein enquanto ser humano existente.

Desde a transformação da essência da verdade da $\alpha \lambda \varepsilon \eta \theta \varepsilon ı \alpha^{5}$ (aletheị̣ para a veritas, a verdade como correção e certeza, em detrimento da aletheia primordial, "a totalidade dos entes, nesse meio tempo, tem se transformado de tal maneira que entes como

\footnotetext{
${ }^{5}$ Verdade enquanto encobrimento e desencobrimento do ser.
} 
um todo, e por isso também o homem, não mais são determinados com base na essência da aletheia" (HEIDEGGER, 2008c, p. 94). Assim, a forma como se passou a determinar o ser humano deixou de ter por base a aletheia, o homem em sua relação essencial com o ser dos entes, passando-se a conceber o homem a partir do humanismo. Não é à toa que Heidegger (2005, p. 21) critica enfaticamente o que chamamos de humanismo:

O Primeiro humanismo, o romano, e todos os tipos de humanismo que, desde então até o presente têm surgido, pressupõem como óbvia a 'essência' mais universal do homem. O homem é tomado como animal rationale.

Considerando que a visão estritamente essencialista e racionalista dos direitos humanos compactua com o humanismo, referida visão estaria fundamentalmente comprometida com a metafísica tradicional; que, por sinal, está alheia à questão do ser dos entes. A pergunta que se faz em relação ao primeiro humanismo descrito é se a essência do homem como tal deveria repousar na dimensão da animalitas. Dessa forma, o homem estaria sendo posicionado como um ente, entre outros, quando, em vez disso deveria ser investigado como um ente em uma relação única com o ser: a da existência. Somente assim se estaria caminhando para a humanitas. Inclusive, porque é a existência humana que torna possível a própria razão ${ }^{6}$, não da forma como a conhecemos no conhecimento científico,

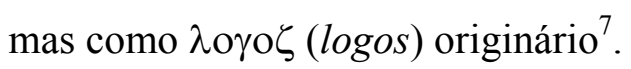

Para Heidegger, portanto, aquilo que tradicionalmente chamamos de essência do homem reside em sua existência (HEIDEGGER, 2005, pp. 21-25). A tarefa do pensamento seria a partir de um novo impulso suscitar a humanitas do homo humanus e a partir daí encontrar sua fundamentação. Esse novo, e, no entanto, tão originário impulso, aborda o ser humano em sua relação com a aletheia, sendo aquele o ente que emerge de si mesmo,

\footnotetext{
${ }^{6} \mathrm{O}$ descobrir do descoberto, que em Aristóteles ainda permeia a essência da teknè. Todavia, transforma-se juntamente com a essência da verdade em um auto-ajustar calculista da ratio. Esta surge da essência da verdade como correção no sentido do auto-ajustar-se indicador, garantia da segurança da dominação. $\mathrm{O}$ "tomar como verdadeiro" da ratio torna-se uma segurança de amplo alcance e antecipatória. Ratio passa a ser a ação de calcular, sendo o auto-ajustamento para o que é correto. A ratio é uma facultas animi, um poder do espírito humano, cujo ato transcorre no interior do homem e diferenciada da ratio está a res, a coisa. Agora, o que está completamente ausente aqui é o espaço essencial da aletheia, o não-encobrimento das coisas e o comportamento revelador do homem (HEIDEGGER, 2008c, pp. 79 e 80).

${ }^{7} \mathrm{O}$ logos originário não se trata de uma disciplina acadêmica ou de uma atividade científica, sendo o próprio pensar, que não é propositivo. Seria uma manifestação do próprio ser enquanto o falar originário, que não se dá pelo enunciado, mas por meio de um apanhar das coisas que as desvela, que as agrupa, em um jogo do dito com o não dito, do desvelado com o encoberto, do tangível e do inefável. Assim, logos originário se encontra na técnica do discurso, propositiva, enunciativa, mas em algo que se aproxima do discurso poético. Não há, assim, distinção entre o ser e o pensar originário, entre o sujeito pensante e o objeto pensado: "pensar é a atenção para o essencial. Em tal atenção essencial reside o saber essencial.(...) Ele se volta para o que o ente é no seu fundamento - para o ser." (HEIDEGGER, 2008c, p. 16)
} 
de tal modo que neste desabrochar, e em favor dele, recebe a palavra ${ }^{8}$. Na palavra ${ }^{9}$ o homem se relaciona com o todo em meio ao qual ele vive. O ente vivente que é o homem é determinado pelo desabrochar e abrir-se. Essa determinação grega da essência do homem logo foi transformada pela interpretação romana: o ente vivente se tornou animal e se tornou ratio, sendo, no pensamento moderno, a razão a essência da subjetividade, isto é, da egoidade do homem (HEIDEGGER, 2008c).

É necessário apontar, contudo, a existência de um fantasma a rondar tal caminho do pensamento: teme-se que falar contra o humanismo redunde em uma defesa do inumano e uma glorificação da barbárie. Todavia, como se sabe, é justamente a metafísica que funda o humanismo, baseada na dicotomia sujeito/objeto, a base para que a maior barbárie presenciada pela humanidade existisse.

Assim, as tentativas de entender o homem por seu ser e de construção ontológica do dasein são realizadas por Heidegger em Ser e Tempo. Neste ponto, buscaremos sucintamente descrever alguns momentos pertinentes (2008a, p. 69) inicia o § 9 de Ser e Tempo com as linhas gerais de sua ontologia da vida humana:

Somos, nós mesmos, os entes a ser analisados. O ser é meu em cada caso. Esses entes, em seu ser, se comportam em relação ao seu ser. Como entes como tal ser, eles são lançados sobre o seu próprio ser. O ser é o que é uma questão para cada um desses entes (tradução livre da autora) ${ }^{10}$.

Pode-se extrair da definição de dasein que os seres humanos têm uma experiência de si próprios que precede a cognição de que todas as experiências são suas. Assim, o dasein se comporta com relação ao seu ser, ou seja, a "essência" do ente humano repousa no seu existir (Weise-zu-sein). Heidegger pretende redirecionar nosso entendimento do que é ser uma pessoa da reflexão e da autoconsciência para como vivemos nossas vidas.

Muitos que não são afeitos às discussões tradicionais acerca da identidade do indivíduo recorrem à filosofia moral, que está preocupada com quem nós somos na medida

\footnotetext{
${ }^{8}$ A essência própria da palavra é que ela deixa os entes aparecerem no seu ser e preserva o que aparece, isto é, o descoberto como tal. O ser se manifesta primordialmente na palavra (HEIDEGGER, 2008c, p. 114).

${ }^{9}$ A essência do homem, portanto, reside no relacionar-se com os entes como tais, pela palavra. Assim como o ser do homem, a essência da palavra é fundada na essência da verdade e a ela pertence; a palavra verdadeira no sentido da aletheia é o mito e a épica (HEIDEGGER, 2008c).

${ }^{10}$ Segue a versão em inglês na qual o texto foi originalmente lido e a partir de cuja interpretação foram extraídas as conclusões presentes neste trabalho: "We are ourselves the entities to be analyzed. The being is in each case mine. These entities, in their being, comport themselves towards their being. As entities with such being, they are delivered over to their own being. Being is that which is an issue for every such entity" (HEIDEGGER, 2008a, p. 69).
} 
em que estamos envolvidos no mundo de forma prática. Todavia, a filosofia moral tradicional, especialmente em Kant, está associada à noção de subjetividade, em que a personalidade moral tem uma unidade lógica, que seria a unidade do agente que é constituída a partir da consciência de sua responsabilidade. Na filosofia moral, portanto, teríamos consciência de quem nós somos por meio da experiência da imputação, da responsabilização (BLATTNER, 2006).

Heidegger, contudo, deseja explorar uma forma mais fundamental de autoconsciência ou descerramento ${ }^{11}$ : um senso de identidade que subjaz à consciência das convicções, dos compromissos, dos pensamentos e das responsabilidades. Desse modo, ser uma pessoa significa projetar alguém a ser, motivo pelo qual nosso ser é uma questão para nós. Nossa vida importa para nós, nos preocupa, mesmo quando a negligenciamos, enquanto que entes não humanos não têm preocupação alguma com coisa alguma; não podem sequer experimentar sua existência como relevante ou irrelevante.

Viver a vida é responder à questão da identidade. Todavia, não confrontamos a questão de quem somos nós refletindo sobre nós mesmos, mas simplesmente vivendo uma vida humana, experimentando. Assim, estamos sempre respondendo à questão da identidade conforme vivemos as possibilidades da vida humana. Nosso auto-entendimento, portanto, é incorporado muito mais no modo como vivemos do que como pensamos ou falamos sobre nossas vidas. Quem nós somos precede e é mais fundamental do que pelo que somos responsáveis. Dessa forma, não há objeção alguma para o desenvolvimento de uma filosofia ética que seja simpática a Heidegger.

Como a questão da identidade está incorporada em como vivemos, não podemos evitá-la simplesmente não pensando ou falando sobre isso. Mais do que isso, a questão da identidade permeia também a nossa relação com os outros: na medida em que me preocupo com quem eu sou também me preocupo com o quem os outros são. Veremos a relação da questão da existência e da identidade com a forma como somos com-os-outros com maior profundidade quando for estabelecido a seguir como se firma a interdependência entre a liberdade e a igualdade.

Conseqüentemente, o homem sobre o qual se estabelecem as bases dos direitos humanos é um ente contingente e vulnerável. Essa contingência do ser é um aspecto da derrelicção com que o dasein vem e está no mundo. Somente pode o homem ser o que ele

\footnotetext{
${ }^{11}$ Heidegger prefere usar a palavra "descerramento" a "autoconsciência" ou "subjetividade" precisamente para evitar as acepções tradicionais de tais termos, calcadas em uma forma de má-subjetividade. Estou descerrado para mim porque me preocupo com quem eu sou.
} 
faticamente é no contexto cultural, social, histórico e lingüístico em que ele se encontra ${ }^{12}$. Assim, a estrutura existencial - determinada pela finitude - torna possível na mesma medida em que limita todo o projetar (GADAMER, 2007a, p. 353). Hans-Georg Gadamer, em seu texto Poema y diálogo, menciona o seguinte poema de Ernst Meister (1911-1979) (MEISTER, [S. d.] apud GADAMER, 1993, p. 151):

Totalmente apartado do bosque e do desejo, o que preocupa o animal

que tem o espírito como dupla galharda?

Uma coisa é verdade: o preocupa seu caminho, falando, é certo, quando tropeça com as esquinas do ar soberano, sua projeção mortal (tradução livre da autora) ${ }^{13}$.

No poema fica claro que o homem se apresenta como um animal totalmente alijado do reino animal. Abandonou o bosque, seu refúgio, e o desejo, que o domina sem questioná-lo, para viver em meio a preocupações. A segunda estrofe trata de quais são essas preocupações e a angustiante situação do homem, quando fora dos caminhos naturais do desejo. O homem expõe-se ao aberto e, assim, à estrutura da pergunta, à duvida. Estamos constantemente expostos a essa situação chamada preocupação.

A angústia pode ser vista como a descoberta da contingência pelo homem, a descoberta de que sua vida não possui um sentido último, mas sim o sentido que ele próprio imprime a ela na medida em que vive, na medida em que escolhe os caminhos e os segue. Essa escolha, na realidade, é o que vem dar significação a todo o resto e não o contrário. Contudo, a vulnerabilidade é mais angustiante ainda do que a contingência, tendo em vista que podemos a qualquer momento ser roubados do que somos pelo mundo, ou podemos morrer para quem havíamos sido ${ }^{14}$.

\footnotetext{
${ }^{12}$ Chamaremos esse contexto de "situação existencial".

${ }_{13}$ A tradução foi realizada a partir da tradução espanhola disponível em Poema y dialogo.

${ }^{14} \mathrm{O}$ mundo pode roubar quem nós somos por não permitir mais que persigamos aquela possibilidade que escolhêramos ou por não permitir que sejamos do modo que somos. Por outro lado, na depressão, ou morte
} 
Dadas a contingência e a vulnerabilidade como características desse ente humano existente, compreende-se como é da própria essência dos direitos humanos a possibilidade de interpretações contingenciais e flexíveis ao longo do tempo e do espaço, que, no entanto, se fazem atuais a cada presente e que dialogam com a tradição. Mesmo porque, apesar de o homem ser contingente e ter consciência de sua situação existencial finita, ele é o único que consegue elevar-se, em certa medida, acima do mundo que o circunda. Ele pode ampliar sua visão de mundo, explorar as possibilidades, que são um misto de sua capacidade de criação e do próprio mundo, e encontrar caminhos para que seu ser perdure para além de sua existência. Além disso, o próprio relacionar-se com as outras pessoas e outros tempos carrega a possibilidade de levar sua identidade para além de si próprio e entrar em contato com outros horizontes.

Assim, a universalidade dos direitos humanos repousa justamente em sua relatividade, tendo em vista a fluidez e capacidade de mudança e superação do mundo circundante desse ser humano que serve de fundamento para esses direitos. A tensão entre o universalismo e o reconhecimento da diversidade cultural no mundo é dissolvida a partir do momento que se reconhece que o modo de ser diversificado e autêntico é o que há de mais universal nos seres humanos. 


\section{A TAREFA DE REPENSAR OS DIREITOS HUMANOS A PARTIR DE UMA FILOSOFIA DA EXISTENNCIA}

A fenomenologia existencial pode contribuir para o diálogo com a tradição dos direitos humanos e para sua constante reinterpretação e recriação. A teoria existencial pode colaborar para se ter uma visão mais hermenêutica dos valores fonte dos direitos humanos, lidando com as dificuldades de sua defesa em um contexto em que os paradigmas morais sofrem uma crise de significação, sendo que o único que encontra certa legitimidade é o próprio paradigma dos direitos humanos. Assim, essa legitimidade somente se sustentará na medida em que houver um olhar hermenêutico adequado sobre esses direitos, que pode propiciar o surgimento de uma nova forma de abordagem e promoção mais igualitária, livre e autêntica.

A primeira questão que emerge para a caracterização dessa crise de significação dos valores seria a forma como encaramos hoje os dísticos do discurso moderno. Será que os enxergamos da mesma forma que os filósofos da Revolução Francesa?

Karl Marx, em sua obra de 1843, denominada A questão judaica, versa sobre os direitos humanos como direitos históricos, de um homem burguês. Com o surgimento do Estado laico e democrático, que relega a religião para o meio dos elementos da sociedade civil, surgem os direitos humanos como uma nova ordem incontestável frente à laicização da sociedade. Segundo Bruno Bauer (1843 apud MARX, 1975, p. 21), são direitos históricos:

A idéia dos direitos humanos só foi descoberta no mundo cristão no último século. Não é uma idéia inata ao homem; pelo contrário, foi conquistada na luta contra as tradições históricas em que o homem, até agora, foi educado. Por conseguinte, os direitos humanos também não são nenhum dom da natureza, nenhum dote da história passada, mas o prêmio da luta contra o acidente do nascimento e contra os privilégios que a história até agora transmitiu de geração a geração. Constituem resultados da cultura e só pode possuí-los quem os mereceu e ganhou.

O ser humano titular dos direitos humanos, justamente por possuir uma essência ligada à existência e ao caminho trilhado por meio de suas ações e escolhas, é um homem que se situa em um momento e em uma comunidade política. O modo de ser dos direitos 
humanos também segue sua situação existencial ${ }^{15}$, tendo em vista que as decisões são necessariamente tomadas na situação que se nos apresenta, quer sejam elas pautadas pelo superficial ou inautêntico, quer sejam pelas determinações profundas da autenticidade. Assim sendo, para Heidegger, é na realidade englobante - realidade social, econômica e política, situação histórica concreta - que o homem existe como dasein.

Vejamos como, de acordo com Sartre, o homem burguês concebia os direitos humanos naquele contexto. Segundo ele (SARTRE, 2006, p. 90), reconhece-se o burguês pelo fato de ele negar a existência das classes sociais e especialmente da burguesia. $\mathrm{O}$ burguês demonstra, pela análise, que todos os homens são semelhantes porque são os elementos invariantes das combinações sociais, e cada um deles, independentemente de seu lugar na escala, contém a natureza humana por inteiro. A partir daí, as desigualdades aparecem como acidentes fortuitos e passageiros, que não podem alterar as características permanentes do átomo social. Não há proletariado, há apenas proletários, cada um isolado na sua natureza humana, e que não estão unidos entre si por uma solidariedade interna, mas somente por vínculos externos de semelhança. O chefe burguês acreditaria tanto em liberdade humana quanto o cientista acredita no milagre.

Houve uma tentativa de universalização do modo de conhecer e relacionar-se com o mundo e com os outros - de forma egoísta e interessada - do membro da sociedade burguesa que necessitava, naquele momento, de determinados direitos humanos, com uma determinada significação. A justificativa para a universalização pretendida repousava na natureza humana que estaria na base de todos os seres humanos, de forma isolada e independente. Entretanto, em nossa visão, a essência humana repousaria justamente na relação do homem com o ser e na existência, o que não se compatibiliza com direitos de um homem universal e atemporal, desvinculado do mundo e do tempo.

O próprio Marx (1975, p. 25) opera uma crítica aos direitos humanos de liberdade, igualdade, segurança e propriedade, supostamente universais, para identificá-los como os direitos humanos burgueses, concluindo que:

Nenhum dos supostos direitos humanos vai além do homem egoísta, do homem enquanto membro da sociedade civil; quer dizer, enquanto indivíduo separado da comunidade, confinado a si próprio, ao seu

\footnotetext{
${ }^{15}$ Que será nesse ponto entendida como conjunto de relações nas quais o ente humano existente se encontra no mundo e com os outros, como entes lançados no mundo com o destino certo da morte. Daí as mudanças no modo com qual o homem se relaciona com a verdade do ser (as "viradas históricas", por exemplo). Esse encontrar-se em situação é sempre um estado de "lançado ao mundo", abandonado a um determinismo que pode impedir ou não as ações humanas, já que sempre é possível trabalhar para mudar uma situação (MAMAN, 2003, p. 82).
} 
interesse privado e ao seu capricho pessoal. O homem está longe de, nos direitos humanos, ser considerado como um ser genérico; pelo contrário, a própria vida genérica - a sociedade - surge como sistema externo ao indivíduo, como limitação da sua independência original. O único laço que os une é a necessidade natural, a carência e o interesse privado, a preservação da sua propriedade e das suas pessoas egoístas.

Marx chega até mesmo a mencionar o "homem verdadeiro e autêntico" que é tomado pelos modernos como o homem burguês (bourgeois), mas que, todavia, deveria ser identificado como o homem cidadão (citoyen). A cidadania, portanto, é reduzida a um meio para a preservação dos direitos humanos egoísta. Além disso, vincular o pleito dos direitos humanos à cidadania apresenta um risco de se obstar a realização deles; risco que adquire concretude principalmente após a Primeira Guerra Mundial, conforme diagnostica Hannah Arendt (2007b, p. 327) em sua obra As origens do Totalitarismo acerca dos apátridas:

A segunda perda sofrida pelas pessoas destituídas de seus direitos foi a perda da proteção do governo, e isso não significava apenas a perda da condição legal no próprio país, mas em todos os países. Os tratados de reciprocidade e os acordos internacionais teceram uma teia em volta da terra, que possibilita ao cidadão de qualquer país levar consigo a sua posição legal, para onde quer que vá (...). No entanto, quem está fora dessa teia está fora de toda legalidade.

Retornando a Marx (1975, pp. 28-30), pode-se dizer que ocorre, portanto, a abolição do caráter político da sociedade civil, que passa a reivindicar privilégios por meio da titularidade dos direitos humanos, em vez de buscar se inserir politicamente no Estado de Direito. Foi cindida a sociedade, portanto, na vida civil e individual e na vida política que preserva os interesses gerais ${ }^{16}$ do povo, sem qualquer permeabilidade entre esses dois mundos.

Já em 1948, contudo, essa concepção dos direitos humanos começa a mudar e o paradigma do homem burguês egoísta e vinculado à sociedade somente na medida de seus interesses começa a ser transformado. Dentre os redatores da Declaração Universal dos Direitos Humanos, Peng Chung Chang esforçou-se para adicionar à idéia de razão a idéia que em tradução literal do chinês significaria "mente de dois homens", cujo equivalente em português ou inglês não existe. Tentaram traduzir essa expressão pelo que em inglês chama-se sympathy, mas referida palavra está longe de sequer tangenciar a expressão chinesa, porquanto é imbuída de subjetivismo (MORSINK, 1999, pp. 296-302).

\footnotetext{
${ }^{16}$ Que preservam a aparência de um conteúdo geral.
} 
Com a percepção de que entre 1789 e 1948 a modernidade não foi capaz de realizar aquilo que havia prometido, sendo que o século XX trouxe experiências, em particular o totalitarismo, nas quais os limites entre o aceitável e o inaceitável desbordaram amplamente daquilo que nos parecia razoável, uma nova forma de pensar o ser humano e sua relação com o mundo tornou-se uma tarefa premente a ser empreendida pela filosofia. A ciência e a técnica enaltecidas pelos modernos, que buscavam basear toda forma de conhecimento e de decisão nesses pilares, foram utilizadas para a legitimação das mais brutais irracionalidades. Heidegger (2008b, p. 171), em 1928, fazendo uma reflexão sobre a crise da ciência, já antecipava esses acontecimentos:

O ser-aí científico não é necessariamente culto, tampouco precisa ser complicado. Portanto, o ser-aí científico não é necessariamente um ser-aí com uma posição hierárquica elevada e não exclui a barbárie. Apesar da ciência, ou quiçá justamente com seu auxílio, tem-se expandido entre nós uma barbárie anônima que talvez só seja pressentida por poucos, pois a maioria se sente bem nessa barbárie. Não é preciso desejar a volta das diligências para poder ver o que uma técnica, impossível sem a ciência, é capaz de produzir hoje para o embrutecimento interior e para a degradação do gosto.

Assim Heidegger defende-se contra as acusações de que o discurso contra o humanismo baseado na metafísica tradicional seria a afirmação da desumanidade e da barbárie. A razão que no humanismo tradicional diferenciaria os homens dos outros entes não humanos, capaz de objetivar, conhecer e dominar todos os entes, a razão universal que fundamenta igualmente a ciência, bem como a "razão de Estado" e a legalidade - que pretendiam ter a mesma objetividade de uma ciência -, enfim, a racionalidade moderna, foi em nome dela que muitas atrocidades ocorreram e que o terror na burocracia e na ideologia se fizeram per leges (LAFER, 1988, pp. 80-114). Foi nesse momento que o Estado conservou a aparência de defensor de um conteúdo geral e assumiu o controle não só da política e da administração, mas também o controle da sociedade civil e dos indivíduos. É certo que a crítica realizada por Marx à divisão da política e da sociedade civil é extremamente pertinente, contudo, a forma como os Estados totalitaristas eliminaram essa barreira provou-se autoritária e irracional. Em vez de a sociedade civil participar da política e das decisões estatais, a administração invadiu a sociedade civil, colocando os indivíduos à sua mercê.

A "razão de estado" foi responsável pela separação de todo patrimônio e tradição ética conquistados até então da esfera pública. Apartaram-se a religião política oficial do 
culto privado, em seguida os padrões éticos gerais do campo das atividades econômicas. Sob a égide das pretensões científicas, o positivismo jurídico passou a sustentar que a moral em seu conjunto nada tinha a ver com o direito considerado em sua essencial pureza e que era possível praticar, de modo juridicamente inatacável, atos de claro aviltamento da pessoa humana (COMPARATO, 2006, p. 364).

Nesse momento observou-se a consumação da completa ruptura da modernidade com a antiguidade clássica, tendo em vista que na antiguidade era impensável que as autoridades alterassem as normas da moralidade tradicional e as regras do culto religioso; havia uma íntima relação da esfera pública com a privada, todavia no sentido de os costumes e tradições ancestrais vigorarem nos dois âmbitos e não no sentido de uma "razão de estado" prevalecer em ambos.

O totalitarismo empreendeu a destruição das estruturas mentais e institucionais de todo um povo, acompanhada da tentativa de reconstrução, a partir dessa terra arrasada, de mentalidades e instituições inteiramente novas. Pode se imaginar o que essa destruição e reconstrução das estruturas sob a égide de um positivismo deva ter causado no campo da ética individual e da moral coletiva.

A obra de Arendt (2007a) Eichmann em Jerusalém: um relato sobre a banalidade do mal retrata como Adolf Eichmann ${ }^{17}$ (1906-1962) encarnava o modelo de virtude para o Estado nazista que consistia na capacidade de repetição maquinal de fórmulas ideológicas, sendo elogiável tão só aquele que se deixa conduzir, mecanicamente, pela obediência cega ao chefe. No vácuo deixado pela moral e pela religião, por conseguinte, introduziu-se a ideologia $^{18}$ veiculada pela propaganda de Estado e pela gigantesca regulamentação destinada aos funcionários do regime. Paradoxalmente, sob a aparência de um sistema racional da forma mais pura, ergueu-se uma máquina burocrática, capaz de impetrar os mais extremos atos de barbárie, cuja complexidade desafiava toda compreensão da lógica (COMPARATO, 2006, p. 369).

Um dos principais fundamentos do regime totalitário foi a oposição entre o Estado burocrático e a totalidade do povo; a perseguição aos inimigos do regime era ferrenha e o povo inteiro tornou-se suspeito, sendo mantido sob vigilância e completa submissão. Como conseqüência, elaborou-se uma política radical de isolamento de cada indivíduo baseada na

\footnotetext{
${ }^{17}$ Foi o funcionário responsável por grande parte da logística de extermínio de milhões de pessoas durante o Holocausto, organizando a identificação e transporte de pessoas para os diversos campos de concentração.

${ }^{18}$ Entendida como explicação dogmática e oni-abrangente do homem e do mundo. Tal ideologia era variável ao sabor das circunstâncias do momento.
} 
delação sistemática. Nas palavras de Comparato (2006, p. 369), “essa coleção de indivíduos, obrigatoriamente separados uns dos outros - porque todos são traidores em potencial (o crime de intenção) -, forma uma massa uniforme, composta de unidades iguais, perfeitamente fungíveis e, portanto, suscetíveis de extermínio em massa". Novamente, aparece aqui o isolamento e a uniformidade, que nada mais são do que a radicalização do conceito de "das Man" (the Anyone, impessoal) cunhado por Heidegger, que será explorado mais adiante.

Dessas fissuras da modernidade, em especial o advento totalitarista, que provocaram um verdadeiro desconcerto epistemológico, e um hiato significativo entre passado e futuro, surge o discurso pós-moderno. Arendt possui uma preocupação com o tema da ruptura, isto é, com a brecha entre o passado e o futuro trazida pelo esfacelamento da tradição intelectual que não tem categorias suficientemente abrangentes para lidar de maneira apropriada com o ineditismo das experiências políticas do século XX (LAFER, 1995, p. 49). Portanto, ela cultiva o compreender como uma forma de reconstrução de um entendimento a respeito do mundo e de nós mesmos, ou seja, com superação desse abismo de significação (ARENDT, 1953 apud LAFER 1988, p. 84):

A compreensão, como algo distinto da informação correta e do conhecimento científico, é um processo complicado que nunca produz resultados inequívocos. É uma atividade sem fim, por meio da qual, em constante mudança e variação, nos ajustamos e nos reconciliamos com a realidade, isto é, nós tentamos estar à vontade no mundo.

O horizonte compreensivo dos modernos baseava-se essencialmente na razão, que era una e absoluta, o que fazia com que todas as concepções modernas fossem universalistas. Nesse sentido, o raciocínio lógico poderia operar alheio ao mundo e à experiência e, por esse motivo, seria incapaz de compreensão. Se o raciocínio lógico é abandonado a si mesmo, torna-se estéril, uma vez que as nuances da realidade não são levadas em conta (LAFER, 1988). Portanto, a interpretação dos direitos humanos e de sua situação jurídica pede, sempre, um olhar compreensivo e hermenêutico. A partir dessas considerações, pretende-se fazer uma proposta de significação dos principais valores dos direitos humanos, que exige que não se perca de vista a efetividade desses direitos, sendo que só há direito quando ele se aplica e sua aplicação atende ao horizonte compreensivo, temporal e histórico (MAMAN, 2003, p. 108). Segundo Jeannette Antonios Maman (2003, p. 109): 
A compreensão histórica mobiliza o passado para projetar o futuro. É nesse sentido que Heidegger afirma que o passado caminha a nossa frente. Entendemos por falar sobre o falado e trazê-lo para o presente, ao seu encontro com a realidade histórica. É a concordância entre interlocutores ou entre texto e realidade que torna a situação dialógica possível.

Assim, os direitos humanos, que são inicialmente vistos como um rol de preceitos morais vinculados a um momento histórico e determinado contexto ${ }^{19}$, devem ser compreendidos historicamente de modo que sua interpretação lhes dê validez jurídica em sua aplicação atual. Sendo a validez e a efetividade dos direitos humanos o que se busca em um contexto intensamente fragmentado como a pós-modernidade, creio que seja legítima a construção de uma nova interpretação que ressignifique esses valores para melhor validá-los.

Primeiramente, devemos fazer uma crítica ao conceito de valor. Heidegger afirma que tudo que é caracterizado como valor tem sua dignidade roubada, porque aquilo que é valorizado é admitido como objeto de avaliação pelo homem; assim, todo valorizar, mesmo quando positivo, é uma subjetivação, em que o que é valorizado é convertido em objeto e em instrumento. Assim, o empenho em demonstrar a objetividade do valor possui uma base completamente corrompida pela subjetividade. Dessa forma, pensar contra os valores estanques, contra os valores convertidos em conceitos à semelhança dos científicos, não significa propagar que algo seja destituído de valor e que não tem importância alguma, mas sim propor uma compreensão desse ente frente ao ser e não como objeto (HEIDEGGER, 2005, pp. 62-63). Seria, portanto, nesse sentido que vemos a possibilidade de repensar e ressignificar os valores dos direitos humanos, enxergando no ato de interpretá-los um momento não de conceituação, mas de liberdade e de ressurgimento do pensar.

Dessa forma, um sistema de valores deve ser encarado com cautela, uma vez que pode acabar equiparando-se a um sistema técnico e estável, que confere segurança e ordenação ao planejar e ao agir humanos. Segurança, contudo, artificial e distante da compreensão do mundo. Todavia, "não seria conveniente poupar e garantir os laços estabelecidos, ainda que somente consigam manter a unidade do ser humano precariamente e apenas na situação de hoje?" (HEIDEGGER, 2005, p. 69). Talvez. Todavia, por quanto tempo o pensar pode esquivar-se de enfrentar o ser e mantê-lo no esquecimento?

19 Uma vez positivados, os valores ficam suscetíveis a interesses e à força, perdendo a flexibilidade necessária para a sua aplicação justa. 
No lugar de um sistema de valores teria lugar, portanto, a ética originária, ou seja, aquela que pensa o homem enquanto alguém que existe. Todavia, seria possível extrair dessa forma de pensar o humano, indicações para a vida ativa? Segundo Heidegger (2005, p. 76), essa forma de pensar não é nem teórica e nem prática, porque não chega a um resultado ou produz um efeito. É um processo contínuo e em constante movimento no tempo, em que os valores éticos serão definidos em cada presente pelo diálogo com o outro e com a tradição, e pela abertura às possibilidades do mundo. Assim, somente a partir da existência e da busca pela identidade autêntica é que o homem pode decidir acerca daquelas ordens que se devem tornar lei e regra para ele. Porque somente assim essas determinações éticas terão a possibilidade de sustentarem-se e vincularem verdadeiramente. Nas palavras de Heidegger (2005, p. 80): “[d]e outra maneira toda lei permanece apenas um artifício da razão humana."

De nossa parte, buscaremos discutir os direitos humanos de forma a dialogar com sua tradição e seus conceitos na tentativa de abrir as possibilidades de criação de uma ética para cada indivíduo; mesmo porque a validade e, conseqüentemente, a efetividade dos direitos humanos somente existirá se iluminarmos e inserirmos esses direitos em uma compreensão para além de seus valores inertes, trazendo-os à vida.

A redação da Declaração Universal dos Direitos Humanos não reflete o ponto de vista particular de um povo ou de um grupo, ou sequer expressa uma doutrina política ou sistema filosófico, sendo o resultado de uma cooperação moral e intelectual; um universo construído conjuntamente a partir da compreensão e dos horizontes de um grande número de nações que conseguiram estar ali abertas para o diálogo. Os redatores estabeleceram a declaração como o chão comum em que devem ser travados diálogos entre as comunidades e nações, tal como caminhos conjuntos e próprios. A declaração seria, portanto, o palco em que os seres humanos se formarão e alcançarão a compreensão e a ética.

A partir dessa orientação, é preciso encontrar nos conceitos fechados, que se dão pela forma enunciativa, e nos direitos humanos o que ainda os resta de inefável e aprender a lidar com o não-dito, como na enunciação poética. É claro que no tempo presente ainda subsistem os mesmos direitos humanos criticados por Marx, todavia, o homem egoísta deve ser ultrapassado, o que não é feito pela interpretação e aplicação que foram dadas aos direitos humanos ao longo dos séculos XVIII, XIX e grande parte do século XX. Os direitos humanos possuem um caráter polissêmico, do qual são extraídos os seus valores ao longo da história. A questão é que a força da ideologia burguesa seria tão poderosa que 
para a maior parte das pessoas a significação dos direitos humanos e de seus valores já teria sido completamente preenchida pelas inúmeras reflexões que foram feitas ao longo da história, não restando qualquer espaço a ser explorado. Contudo, como visto, para a filosofia e para a ética, não existem resultados, como nas ciências. É necessário que os pensamentos dialoguem e se renovem.

No existencialismo de $O$ ser e o nada (SARTRE, 2008), a liberdade é exercida à medida que existe um projeto a ser realizado, sendo que este projeto é definido a partir de uma nadificação do estado real das coisas, ou seja, o projeto deve ser possível, realizável, mas não consumado. Para que essa possibilidade seja percebida é necessário que haja um enfoque não no que se é, ou no que existe, mas, sim, no não-ser. Desse modo, a realidade deve ser vista sempre como insuficiente, possível de ser melhorada ou transformada, com a perspectiva de uma ação que venha a realizar o nada que está latente. Segundo Sartre (2008, p. 538):

Enquanto imerso na situação histórica, o homem sequer chega a conceber as deficiências e faltas de uma organização política ou econômica determinada, não porque 'está acostumado', como tolamente se diz, mas porque apreende-a em sua plenitude de ser e nem mesmo é capaz de imaginar que possa ser de outro modo (...); pelo contrário, é a partir do dia em que se pode conceber outro estado de coisas que uma luz nova ilumina nossas penúrias e sofrimentos e decidimos que são insuportáveis.

Desse modo, somente a partir do desprendimento de si e do mundo é que podemos posicionar nossa situação como insuficiente ou, no limite, como fonte de um sofrimento insuportável. Esse sentimento de precariedade com relação ao mundo vivido, ao que é, se transforma, a partir do desprendimento e da transcendência para o futuro, rumo a uma possibilidade, pode ser tido como o móbil ${ }^{20}$ para a ação. Evidente que o que chamamos de "sentimento de precariedade" possui a gênese no nada, todavia, pode manifestar-se como diversas espécies de sentimentos, os mais particulares.

Para a consciência, essa identificação do nada significa a possibilidade permanente de efetuar uma ruptura com o próprio passado, de desprender-se dele para poder considerálo à luz de um não-ser e conferir-lhe a significação que tem a partir do projeto de um sentido que não tem. Assim, em caso algum o passado pode espontaneamente produzir um ato, ou seja, o posicionamento de um fim que se volta sobre ele para iluminá-lo; a

\footnotetext{
${ }^{20}$ Para Sartre (2008), móbil é o elemento subjetivo, o conjunto dos desejos, emoções e paixões que nos impele a executar certo ato. Referido móbil, contudo, somente adquire significado a partir de um projeto futuro.
} 
nadificação é parte indispensável para o posicionamento de um fim e nem se diga que a condição indispensável para toda a ação é a liberdade do ser atuante.

$\mathrm{Na}$ teoria existencialista de Ser e Tempo, o passado é visto de forma muito semelhante. Para Heidegger, o passado é a experiência vivida. Em sua teoria, desprende-se do passado no "deixar para trás", sendo que se opera uma desconstrução do passado para que se possa entendê-lo de outra forma, desconstruindo-se para construir. Contudo, Heidegger entende que a ruptura com o passado não se dá de maneira tão radical, tendo em vista que ele considera a tradição e as escolhas passadas como possíveis determinantes das escolhas futuras. Isso ele denomina destino. Assim, a partir de uma escolha passada já se delinearam alguns caminhos possíveis e só podemos escolher dentre esses caminhos já delineados. Por outro lado, o ser é dotado de historicidade, o que implica dizer que no mundo da vida, sendo este o mundo vivido, já experienciado e, portanto, limitado, encontra-se a tradição. Dessa forma, a tradição é situação existencial e também condição existencial. Temos imagens mentais de muitas coisas (representação mental), que já passaram para o conhecimento como tradição.

A tradição nada mais é do que uma experiência vivida, mas não por nós que estamos vivendo a tradição de agora. Para se possa tomar consciência dessa tradição e se relacionar com ela de forma livre, é preciso trazê-la para o presente através de sua interpretação e dialogar com ela. Nesse diálogo, a tradição será constituída como um tu e assim como em um diálogo, os horizontes do presente e do passado estarão fundidos. É possível, portanto, retirar-se e relacionar-se livremente com a tradição ${ }^{21}$, uma vez que ignorar a influência que a autoridade da tradição possui sobre nossas ações seria submeterse cegamente a ela. Não se trata de elaborar uma nova representação, mas sim de repensar os fenômenos, o que nos fará procurar uma nova significação que se faz presente no agora. É possível, portanto, superar de alguma forma do destino que nos foi delineado por outros no passado e talvez por nós mesmos no presente ${ }^{22}$. A historicidade da existência humana em toda sua mobilidade do relembrar e do esquecer, o fato de o homem pertencer e fazer a história, é justamente a condição de possibilidade de atualização do passado.

\footnotetext{
${ }^{21}$ Esse retirar-se, para Heidegger, pode ser considerado como um distanciamento para a compreensão do todo.

$22 \mathrm{O}$ único destino do qual não se pode de forma alguma escapar, que não foi definido por nosso passado é a morte, que também é uma possibilidade, não constituindo um fim, ou um fato. Todavia é uma possibilidade própria, pois diz respeito ao próprio ser do homem individualmente considerado, isolando-o consigo mesmo; insuperável, sendo a renúncia da existência a si mesma. Viver para a morte é compreender a impossibilidade da existência.
} 
Lançado na existência, na situação de derrelicção, o homem precisa projetar individualmente e coletivamente, tendo em vista que sua existência é ser-no-mundo-comos-outros. Isso significa que o que se chama de estar-lançado e o projeto pertencem-se mutuamente. $\mathrm{O}$ futuro passa a ser uma expectativa, sendo que o passado lhe dá um esboço dos valores e das diretrizes que podem guiar o futuro. O homem, portanto, é um ente que ao compreender sua existência, passa a se preocupar com seus objetivos. Tendo em vista o encontro com a experiência do passado, ele passa a projetar seu futuro. Por esse motivo Heidegger afirma que o passado caminha à nossa frente. Segundo Maman (2003, p. 54):

\begin{abstract}
Nossa existência é temporal, a história é o conteúdo fático, feito de acontecimentos que se situam nessa experiência humana, que tem uma memória ou presença do passado e uma projeção para o futuro - não é a história do ponto de vista transcendental, é a história efeitual. Passa-se daí à contemplação do mundo como conjunto de entes subsistentes que se põem diante de nós. Primeiro víamos e vemos o mundo como um conjunto de utensílios, totalidade dos entes.
\end{abstract}

Para Heidegger, portanto, os entes adquirem sentido para o ser humano existente na medida em que se inscrevem num sistema de significações, em um sistema de projetos ("afim-de") e motivações (“por-causa-de") que se articula significativamente.

Retornando ao pensamento de Sartre sobre o mesmo problema, tem-se que assim como o futuro retorna ao presente e ao passado para iluminá-los, também é o conjunto de meus projetos que retrocede para conferir ao móbil, como visto anteriormente, sua estrutura de móbil. É somente porque escapo ao Em-si, nadificando-me rumo às minhas possibilidades, que este Em-si pode adquirir o valor de motivo ou móbil. Dessa forma, há uma alteração de significação nas representações de si mesmo, do presente e do passado. O distanciamento para Sartre também existe à medida que o não-existente refere-se ao eu mesmo enquanto transcendência, eu mesmo fora de mim. Assim, "estou condenado a existir para sempre para-além de minha essência (...): estou condenado a ser livre" (SARTRE, 2008, p. 543).

Analisando o passado em que a barbárie encontrou seu ápice sem precedentes sob o prisma das teorias existencialistas foi que Arendt elaborou uma ressignificação desse passado, cogitando um futuro, valeu-se da tradição da filosofia e dos direitos humanos para superá-la. Arendt trata de uma ruptura que se dá com o advento dos regimes totalitaristas, que surge provocando um hiato, desconcerto epistemológico. Tudo isso porque a lógica do razoável que permeia o paradigma da Filosofia do Direito não pode dar conta da não- 
razoabilidade característica das experiências totalitárias. As experiências totalitárias tiveram berço na própria modernidade, surgindo como desdobramento inesperado de seus valores. $\mathrm{O}$ campo de concentração, símbolo do totalitarismo no século XX, base do modelo de organização da sociedade totalitária, torna vã e descabida a discussão acerca dos critérios de Justiça. Assim, o ineditismo desta ruptura está no fato de que o totalitarismo é uma proposta de organização da sociedade que escapa ao bom senso dos critérios de justiça, baseando-se no pressuposto de que os seres humanos são e devem ser supérfluos (LAFER, 1988).

Essa superfluidade da pessoa humana contesta frontalmente a idéia do valor da pessoa humana enquanto "valor-fonte" de todos os outros valores políticos, sociais e econômicos e, assim sendo, como fundamento da legitimidade da ordem jurídica, seja no âmbito do paradigma do Direito Natural, seja no âmbito da Filosofia do Direito (LAFER, 1988).

A ruptura totalitária, ainda, destrói a possibilidade de uma vida pública autêntica na medida em que promove o isolamento dos indivíduos, culminando na desolação. A ruptura totalitária obsta a vida privada, exacerba o desenraizamento e dificulta o pensamento (LAFER, 1988). Além disso, a utilização e glorificação da violência desmedida pelo Estado e pelos cidadãos representavam um sintoma da severa frustração da faculdade de agir no mundo moderno e contemporâneo; que tem suas raízes na burocratização da vida pública, na vulnerabilidade dos grandes sistemas e na monopolização do poder que seca as autênticas fontes criativas. Quem perde a capacidade de agir em conjunto, sejam governantes ou governados, dificilmente resiste à tentação da dominação pela violência (LAFER, 1995, p. 51).

A reconstrução dos direitos humanos inspirada no pensamento de Arendt refere-se aos direitos que devem ser tutelados porque podem impedir a reconstituição de um Estado totalitário de natureza. São direitos que garantem a sobrevivência e a participação do/no espaço público e combatem o isolamento. Nesse caso, a ruptura com o passado e a atribuição de novos significados ao passado totalitário a partir de uma reconstrução das idéias dos direitos humanos e de um ideal de valorização da pessoa humana foram frutos principalmente dos eventos históricos que provocaram um hiato, um vácuo conceitual temporário. Todavia, referido hiato possibilitou que houvesse um relativo distanciamento, a formulação necessária de novas representações a partir de novos fins, em vista do nada que havia se tornado evidente naquele momento de vazio epistemológico. Em suma, foi uma oportunidade para que a liberdade se desenvolvesse em sua plenitude, em que os 
conceitos de liberdade, igualdade, autoridade, dignidade e do próprio ser humano tiveram de ser reformulados, em um diálogo com a tradição que partiu da crítica à modernidade e do resgate à antiguidade.

A partir da ruptura totalitária, passam a surgir diversas bandeiras, cujo colorido denuncia a hipocrisia dos universais modernos. A ontologia fundamental de Heidegger supera a crítica de Kant a partir de uma análise abrangente do ser humano, de uma compreensão temporal e histórica, escapando à universalidade da razão (MAMAN, 2003, p. 84). O ano de 1968 foi marcado pelo pensamento a partir de fragmentos e da desconstrução das metanarrativas do discurso moderno. Passa-se a repensar, portanto a história dos legados da vida moderna. A partir da fragmentariedade e da desconstrução desse legado, constrói-se o pensamento acerca do curso da civilização guiado principalmente pela liberdade.

\subsection{LIBERDADE E IGUALDADE}

A breve elucidação acerca da temática da liberdade humana feita anteriormente foi necessária para a sugestão da necessidade de uma interpretação e de um olhar hermenêutico sobre os direitos humanos; em especial sobre os direitos positivados no artigo $1^{\mathrm{o}}$ da Declaração Universal dos Direitos Humanos, que servem de base à compreensão de todos os outros, como uma parte importantíssima a significar o todo. A fenomenologia existencial pode ser utilizada aqui, em outro patamar, para esboçar a significação que vem adquirir a liberdade como direito humano dentro da proposta hermenêutica pretendida neste trabalho.

Assim, a primeira pergunta que se deveria fazer seria a seguinte: com base em quê o homem realiza um determinado projeto. Na situação de derrelicção, ou seja, lançado na existência, o homem deve projetar ${ }^{23}$. Seu passado e a sua situação existencial lhe fornecem um esboço do que deve fazer no futuro. Todavia, essa tensão provocada pela incerteza do caminho a ser escolhido não exclui o outro, muito pelo contrário. O cuidado de si abarca o outro, tendo em vista que o indivíduo reconhece a si mesmo no outro, reconhece o outro como pessoa.

\footnotetext{
${ }^{23}$ Seu projeto é de vida individual e coletiva, uma vez que existir é ser-no-mundo-com-os-outros.
} 
Aristóteles (2008, p. 26) em sua sistemática dissertação sobre a ética diria que essa preocupação advém do fato de o homem ser um "animal político". Para ele, quando o homem busca a felicidade pode fazê-lo através da auto-suficiência, contudo, "por autosuficiente não entendemos aquilo que é suficiente para um homem isolado, para alguém que leva uma vida solitária, mas também para os pais, os filhos, a esposa, e em geral para os seus amigos e concidadãos (...)". Para ele, portanto, a felicidade é algo absoluto e autosuficiente, a finalidade da ação. Vale lembrar, contudo, que o pensamento dos antigos propunha a solução do "homem como animal social" na medida em que a liberdade se realizava na polis, justamente no exercício social e político. O público e o privado não eram distintos ou segregados e o nomos regulava igualmente com minúcia todos os aspectos da vida social. A ética dos antigos, portanto, jamais se concebeu como fundada na vontade humana ${ }^{24}$ (COMPARATO, 2006, p. 63).

A liberdade dos antigos, portanto, jamais poderia ser recepcionada pelo homem moderno, cujo projeto concentra-se primordialmente em fruir tranquilamente sua "independência privada". A independência individual é mais do que a busca deliberada pela felicidade, torna-se uma necessidade e não deveria ser sacrificada em prol do estabelecimento de uma vontade política. Por conseguinte, o homem moderno abdica de seu direito de participar do poder político e o coloca nas mãos dos "depositários da autoridade". A felicidade buscada pelo homem moderno divide-se em duas frentes: a busca incessante pela independência privada e a segurança que lhe será concedida pelo Estado de Direito. Todavia, a busca pela independência individual é ilusória, visto que a própria concepção do indivíduo é muito frágil e duvidosa. Por outro lado, ao colocar sua a realização de sua felicidade nas mãos do Estado, o homem entrega-se como vida nua, que demanda um vínculo de nacionalidade (AGAMBEN, 2007).

\footnotetext{
${ }^{24}$ Não podemos entender de um modo preciso a posição do espírito grego e sua relação com a questão filosófica da individualidade e com o Estado se adotarmos um ponto de vista estritamente moderno. A vivacidade espontânea, a sutil mobilidade, a íntima liberdade, não têm suas raízes no cultivo da subjetividade, como atualmente acontece. Muito antes de terem delineado a idéia da individualidade, os gregos já consideravam as coisas do mundo numa perspectiva tal que nenhuma delas lhes parecia isolada do resto, mas sempre como um todo ordenado em conexão viva (JAEGER, 1986, p. 8). A tendência do espírito grego para a clara apreensão do real, tendência patente em todas as esferas da vida radica-se na concepção do ser como estrutura natural, originária e orgânica. A polis, por conseguinte, era essencialmente vinculada ao espírito grego e, portanto, ao ser, sendo o ser do homem vinculado às características do homem como ser político. Assim, a formação pessoal dos homens impulsionava o espírito comum.
} 
Relativamente ao conceito de indivíduo, remetemo-nos a um personagem/divindade evocado por Nietzsche ao tratar das forças que se opõem e em vão buscam equilíbrio em uma luta simbólica retratada pelas tragédias. A figura de Apolo representa a experiência onírica: um traço marcante e indispensável dessa experiência é a linha delicada que a imagem onírica não pode ultrapassar, isto é, "aquela limitação mensurada, aquela liberdade em face das emoções mais selvagens, aquela sapiente tranqüilidade do deus plasmador" (NIETZSCHE, 1992, p. 29). E assim poderia valer com relação a Apolo, em um sentido excêntrico, aquilo que Schopenhauer (1819 apud NIETZSCHE, 1992, p. 30) observou a respeito do homem colhido no véu de Maia, na primeira parte de $O$ mundo como vontade e representação:

Tal como, em meio ao mar enfurecido que, ilimitado em todos os quadrantes, ergue e afunda vagalhões bramantes, um barqueiro está sentado em seu bote, confiando na frágil embarcação; da mesma maneira, em meio a um mundo de tormentos, o mundo individual permanece calmamente sentado, apoiado e confiante no principium individuationis.

Da mesma forma, Schopenhauer descreve o terror que nos toma ao sermos desviados do princípio absoluto da razão quando experimentamos as formas cognitivas da aparência fenomenal. Esse desvio seria uma visão da essência do dionisíaco que é trazido a nós pela analogia com a embriaguez, ocasionando uma ruptura do frágil principium individuationis. Todavia, esse olhar, essa abertura, não deveria ser tido como um desvio, mas sim como o verdadeiro conhecimento, sendo que o que distingue o homem é ele próprio ser tocado pelo ser, de tal maneira que no mostrar-se do homem, no seu ver e na sua vista, o próprio extraordinário aparece (HEIDEGGER, 2008c).

Dando continuidade a nossa explicação acerca da liberdade e de sua interdependência com a igualdade, passo a uma breve explicação de como a fenomenologia existencial de Heidegger encara a ruptura do principium individuationis. Para Heidegger, referida ruptura não é concebível, tendo em vista que o indivíduo não aparece encerrado em sua mônada. Ele encontra-se já transcendente, para fora dela. Por isso, não seria necessário que houvesse uma ruptura desse princípio, tendo em vista que o indivíduo não seria assim configurado. O dasein de Heidegger é projetado para fora de si e esse "sair em direção a" perfaz sua essência. O rompimento de Heidegger com a tradição filosófica, nesse sentido, é primordial. Mais especificamente o rompimento com a relação sujeito-objeto. 
Primeiramente, é preciso clarificar qual é o conceito de sujeito com o qual Heidegger realiza uma ruptura. A argumentação acerca do caráter subjetivo da verdade não pode esconder que sua base é totalmente frágil; e isso porque o conceito de sujeito permanece indeterminado. No sentido tradicional, que é pressuposto na argumentação usual, "o sujeito é um eu inicialmente encapsulado em si e cindido de todos os outros entes, um eu que se comporta de maneira bastante auto-efervescente no interior de sua cápsula. Denominamos essa concepção do mero sujeito a má subjetividade" (HEIDEGGER, 2008b, p. 120). Esse conceito não traz consigo, como se verá a seguir, "senão um fantasma e uma construção arbitrária de um eu” (HEIDEGGER, 2008b, p. 121).

A própria essência da verdade impele-nos para uma revisão do conceito de sujeito. O pertencimento da verdade ao sujeito compreendido como dasein pode se tornar justamente a ocasião para determinar pela primeira vez o conceito de sujeito de modo correto. Assim, o desvelamento do ente pertence essencialmente ao sujeito; isto é, pertence essencialmente ao sujeito o fato de ele não estar encapsulado em si, mas sempre já ser junto ao ente. Para Heidegger, portanto, a essência originária da verdade não parte do enunciado que estabelece uma relação sujeito-objeto, mas precede essa relação na medida em que parte da permanência junto ao ente, o que significa que o ser-aí (dasein) é primordialmente uma imanência para outro ente. Dessa concepção parte o desvelamento, que é o conceito substituto de consciência e de compreensão utilizados pela tradição filosófica, ou seja, em vez de falar do ser humano como consciente ou de sua intencionalidade, Heidegger afirma que o mundo é desvelado para nós e por nós. Esse desvelamento desdobra-se em três componentes, que, contudo, ganharão maior destaque nos capítulos posteriores: disposição, entendimento e discurso.

Pode-se afirmar, portanto, que a tese do $\S 13$ de Ser e Tempo é de que a cognição é fundada no ser-no-mundo. Isso significa que tanto a familiaridade, enquanto uma forma de pré-cognição é mais fundamental do que a cognição, como a cognição não é autosuficiente, mas sim derivada de uma forma de familiaridade. $\mathrm{O}$ ser humano que existe estando inserido no-mundo não é o sujeito cognoscente de um objeto. Tendo em vista que estamos imersos no mundo em que vivemos, experimentamos o mundo como nosso. $\mathrm{O}$ mundo não se apresenta como um objeto de estudo e conhecimento, mas antes como um "meio social".

A tradição filosófica teria, portanto, compreendido erroneamente a experiência humana pela imposição de um esquema relacional nos moldes do sujeito-objeto como 
estrutura externa da consciência. $\mathrm{O}$ ser humano individual tem sido tradicionalmente compreendido como um animal racional, ou seja, um animal com poderes cognitivos, em particular o poder de representar o mundo à sua volta; disso decorre que a noção de que os seres humanos são o centro da experiência subjetiva tem sido amplamente aceita. A tradição equivocou-se, mais especificamente, em ter interpretado a subjetividade por meio de conceitos de "interno" e "externo", "representação" e "objeto". Essa linguagem, que oferece uma descrição distorcida de nossas experiências, sugere um abismo entre o sujeito e o objeto, que deve ser superado por uma conquista cognitiva. Além disso, o vocabulário que retrata a experiência subjetiva domina a filosofia moderna desde Descartes, passando por Kant, até Husserl.

Essa forma de cognição somente faria sentido, na concepção heideggeriana, em um contexto em que houvesse uma deficiência no nosso ser-no-mundo, em uma situação em que a nossa familiaridade normal com o mundo tivesse se tornado problemática. $\mathrm{O}$ isolamento do mundo, portanto, não é comum, mas sim uma forma não usual de ser-nomundo. Normalmente, estamos familiarizados com o mundo e as coisas que nos circundam não apresentam qualquer problema para nós. A linguagem de "interior" e "exterior" não retrata minimamente esse tipo de experiência.

Heidegger oferece uma descrição alternativa de experiência. Ele argumenta que a nossa experiência fundamental do mundo é de familiaridade. Não temos a experiência de nós mesmos como sujeitos superiores e em oposição a objetos, mas sim a experiência de estar em casa, em um mundo que já compreendemos. Essa compreensão é relativa a uma verdade primordial $^{25}$ que reside na função descobridora e reveladora de nossa familiaridade, anterior a qualquer verdade enunciativa. Agimos em um mundo no qual nos encontramos imersos. Quem nós somos não pode ser desenredado do mundo a nossa volta. Assim sendo, somos o que importa para nós em nossa vivência, somos implicados no mundo. A face existencialista da verdade primordial seria a confrontação do ser humano com a face mais elementar de seu ser, ou seja, com o tipo de ente que esse ser humano é: com o modo de ser desse ente que é um ser humano existente (dasein). Como veremos mais adiante, essa confrontação abre caminho para a autenticidade e o empoderamento de nosso próprio ser.

De forma análoga, normalmente nossa interação com os outros não apresenta dificuldades, isso porque o próprio dasein é um-com-o-outro. Segundo Heidegger (2008b,

\footnotetext{
${ }^{25}$ É a verdade relacionada à pré-cognição do mundo e de nós mesmos como inseridos no mundo com o outro, em oposição à verdade enunciativa e conceitual. Essa verdade será explorada no segundo capítulo.
} 
p. 151), fatos do ser-um-com-o-outro sempre foram conhecidos, sendo que o próprio Aristóteles falava do homem como um ser vivo que deve ser em comunidade. Também o ser-um-com-o-outro não se trata de uma relação entre sujeitos. A relação de troca entre sujeitos foi colocada pela primeira vez por Leibniz em sua Monadologia. Todavia, Leibniz expressa essa questão nos moldes do conceito tradicional de sujeito. Ele apresenta uma interpretação monadológica do sujeito, sendo que o intercâmbio possível entre os homens seria uma questão de relação entre as substâncias em geral:

Toda mônada singulariza como tal a si mesma; toda mônada é a cada vez por si, na medida em que "forma" o todo. Mesmo os seres-aí [dasein], mesmo os homens são tomados como mônadas. Formando a si mesmas, as mônadas não carecem de recepção, sua essência não inclui nenhuma receptividade oriunda de fora. Mônadas não tem janelas porque não precisam de nenhuma janela; não precisam de nenhuma janela porque têm tudo em si, porque são pura e simplesmente fechadas, porque não são abertas. Não carecem de nenhum intercâmbio, nenhuma relação com os outros. (...) Em contrapartida, a empatia dá uma janela às mônadas (sem grifos no original) (HEIDEGGER, 2008b, p. 153).

Em contrapartida, a concepção de Heidegger da relação entre os homens é de que o sujeito não precisaria de uma janela, uma vez que este já se encontra projetado para fora. A empatia, portanto, só existe quando há uma deficiência no ser-um-com-o-outro, quando há indiferença ou alguma calosidade na relação entre os homens. Como na tradição filosófica os dois sujeitos (o eu e o outro) são subdeterminados como sujeitos parciais, para conceber uma comunicação entre esses dois sujeitos é necessário buscar um expediente mais rico. Dessa forma, "a subdeterminação da subjetividade provoca uma superdeterminação da relação entre sujeito e sujeito" (HEIDEGGER, 2008b, p. 149).

O conceito tradicional de sujeito que foi aqui problematizado pressupõe a separação da existência humana em diversos âmbitos: sujeito-objeto, sujeito-sujeito, sujeito-mundo, público-privado. A visão do indivíduo como sujeito traz consigo a fragilidade do principium individuationis. Outro personagem mitológico que representa muito bem a ruptura desse princípio e o extravasamento do sujeito, sua imanência, é Narciso. A introdução do narcisismo na psicanálise é decisiva, sendo que o narcisismo, aparentemente uma retirada egoísta ante a realidade, é aqui representado como a unicidade com o universo: para além de todo o auto-erotismo imaturo, o narcisismo significa um relacionamento fundamental com a realidade. O narcisismo primário abrange o meio, integrando o ego narcisista e o mundo objetivo. Assim, para a psicanálise, a relação 
antagônica entre ego e realidade externa é apenas uma forma e um estágio ulteriores da relação entre ego e realidade, sendo precedida pelo fundamental sentimento oceânico. (MARCUSE, 1968, p. 153). Ao contrariar a separação do objeto do sujeito, Narciso nos traz uma reflexão interessante: como pode o "egoísmo" aparente coexistir com uma irrupção para o mundo e para o outro? A resposta de tal questão pode colaborar para a resposta de em que moldes se dá o ser-um-com-o-outro para Heidegger. Essa resposta também demonstrará a vinculação essencial da liberdade com a igualdade.

Devemos definir primordialmente o ser-um-com-o-outro como um compartilhamento da verdade ${ }^{26}$. Tendo em vista o ser humano como ente que possui um ser essencialmente descobridor, os outros entes (sejam entes por si subsistentes, ou entes à mão ou o outro dasein) estão para ele e são por ele desvelados. Contudo, o próprio dasein como tal está desvelado em seu ser junto aos entes. Como já explicado, o dasein não é de modo algum algo que se manteria inicial e ocasionalmente em uma esfera chamada interna. Assim, o próprio dasein está manifesto; o dasein é descerrado ${ }^{27}$ por si mesmo, mesmo que um outro dasein não o apreenda faticamente, mesmo que ele esteja faticamente isolado. Essa manifestação do dasein e do ente que está junto a ele, dentro da esfera de imanência de seu $a i$, acontece de modo essencial, e não de modo ocasional e ulterior. Na medida em que o dasein existe, ele já foi arrancado de seu velamento. O dasein, porém, não é desvelado isoladamente, ele carrega consigo um círculo do descoberto. Onde quer que esteja, sempre se movimenta em tal círculo. Dessa forma, nas palavras de Heidegger (2008b, p. 145):

\begin{abstract}
Na presença de um outro ser-aí, o ser aí não está com esse outro porque os dois possuem a mesma constituição. Eles estão, sim, muito mais um com o outro porque são seres-aí, porque eles, na medida em que são, trazem consigo um aí e, dessa forma, como entes que trazem consigo necessariamente um aí, entram no círculo do outro, de modo que compartilham esse círculo.
\end{abstract}

A metáfora que utilizaremos para ilustrar o círculo de manifestação é a música. Cada músico em uma orquestra, por exemplo, está junto a seu instrumento, sendo que o instrumento que lhe é familiar se desvela para ele em seu uso. Ao mesmo tempo, o resultado desse desvelamento é expresso na melodia que ambos, músico descobridor e instrumento descoberto, irrompem. Essa irrupção do dasein junto ao instrumento musical é o seu descerramento, e, nessa metáfora será identificado com a música. E cada músico

${ }^{26} \mathrm{O}$ compartilhamento de uma tal verdade não significa que outros necessariamente dela se apropriem de modo expresso.

${ }^{27} \mathrm{O}$ desvelamento do dasein é denominado descerramento. 
irradia um som diferente que se mistura e se amplia com círculo sonoro de outros músicos, formando o todo, uma música única. Para esse exemplo é adequada uma passagem do livro A Parte e o Todo de Heisenberg ${ }^{28}$ (1996, p. 286):

Von Holst buscou sua viola, sentou-se entre os dois rapazes e juntou-se a eles na execução da Serenata em ré maior, uma obra da juventude de Beethoven. Ela é transbordante de alegria e força vital; a confiança na ordem central dissipa a covardia e o cansaço. Enquanto eu ouvia, fortaleceu-se minha conviç̧ão de que, avaliadas pela escala temporal humana, a vida, a música e a ciência prosseguiriam para sempre, ainda que nós mesmos não sejamos mais do que os visitantes transitórios, ou, nas palavras de Niels Bohr, simultaneamente expectadores e atores do grande derma da vida (sem grifos no original).

Dessa forma, o ser-um-com-o-outro é um modo fundamental de ser do dasein, sendo que a distância espacial fática dos lugares em que ou eu e o tu mantêm-se é absolutamente superável. Além do ser-um-com-o-outro como compartilhamento da verdade como desvelamento, temos o que Heidegger chama de cuidado. Quando confrontamo-nos com a questão de nossa identidade, estamos também frente à questão da identidade dos outros, ou melhor, não posso desemaranhar quem eu sou de quem os outros à minha volta são. Evidentemente, que existem graus de intimidade no cuidado com os outros maiores ou menores. Pode ser que nos comprometamos profundamente ou estejamos indiferentes, tendo em vista que cuidado, aqui, não significa particularmente preocupação. Comparato (2006, pp. 461-462) também não deixa de lado essa questão ao tratar da ética:

O homem jamais pode sentir-se e enxergar-se como um ser isolado do mundo. Em reação contra a tendência a um certo solipsismo da filosofia pós-medieval, a partir do cogito cartesiano, o pensamento filosófico, desde Hegel, não cessa de focalizar a realidade essencialmente relacional da vida; implícita na estrutura do próprio vocábulo consciência: saber conjunto, cum + scientia (sem grifos no original).

Desse modo, quem os outros são é uma questão em aberto que importa para como alguém vive sua própria vida. Conforme vivemos nossas vidas, nos engajamos com pessoas e o modo como elas se compreendem não é irrelevante para nós. Sem contar que em geral "a presença fática está no mundo comum, descoberto pela medianidade. Numa primeira aproximação, "eu" não "sou" no sentido de $\operatorname{mim}^{29}$ mesmo e sim os outros nos moldes do impessoal.” (HEIDEGGER, 2008d, p. 187). Assim, o descerramento em que nos

\footnotetext{
${ }^{28}$ Werner Karl Heisenberg (1901-1976) foi o físico alemão formulador do Princípio da Incerteza.

${ }^{29}$ Optei substituir a palavra "si" da tradução da edição aqui apontada para adequar-se melhor à tradução para a língua inglesa de John Macquarrie e Edward Robinson, que parece ser mais adequada, qual seja, "my own self".
} 
concebemos como filhos, alunos, advogados, professores está enredado, como visto, com o descerramento de nossos pais, professores, clientes, alunos. Conforme sustentamos quem somos e como somos, também sustentamos quem os outros são e como são. Assim, meu eu não é independente dos eus de outros à minha volta. Esse fenômeno pode ser chamado de imersão no mundo social (BLATTNER, 2006), o que não se confunde com o comunitarismo.

É inevitável tratar da relação entre homens sem abordar um tema que tem sido reiteradamente discutido na filosofia, especialmente no âmbito da ética: a comunidade. Essa questão, porém, em geral não é colocada como sendo da metafísica do dasein. Como dissemos, em geral, não nos encontramos isolados dos outros, mas sim imersos no mundo, com os outros. Compartilhamos o horizonte social que torna o que fazemos inteligível mutuamente e percebemos os outros também em termos de suas motivações e ações. Aliás, nossas motivações e ações estão entrelaçadas, sendo que ser quem eu sou é agir para que outros sejam quem eles são também. Segundo Heidegger (2008a, p. 160) "por ser-com, Dasein 'é' essencialmente por-causa-de outros" (tradução livre da autora) ${ }^{30}$. Assim, simplesmente porque o dasein é no-mundo, ele é-com. E justamente porque e na medida em que sua vida importa para ele próprio, a vida dos outros importa para ele. Como dissemos, Heidegger chama esse importar-se consigo próprio e, em última instância, com os outros de cuidado. É importante ressaltar, no entanto, que o cuidado não se refere a um estado emocional específico como a preocupação ou a devoção. Os outros são importantes para nós na medida em que vivemos nossas vidas.

Vale ressaltar que o intuito de Heidegger com Ser e Tempo não é ético, sequer político, mas sim ontológico. Assim, o comunitarismo ontológico significaria que ser um ser humano é ser membro de uma comunidade ${ }^{31}$. Para os propósitos desse trabalho poderia parecer à primeira vista muito conveniente adotar o comunitarismo ontológico, contudo, não acreditamos que o propósito de Heidegger em Ser e Tempo e mais especificamente com o ser-um-com-o-outro fosse este. O mundo compartilhado de Heidegger não é necessariamente uma comunidade nesse sentido. O comunitarismo ontológico seria um entendimento pouco profundo do ser-um-com-o-outro, uma vez que o que se compartilha é mais universal do que referências específicas de uma determinada comunidade política ${ }^{32}$.

\footnotetext{
${ }^{30}$ Segue a versão em inglês na qual o texto foi originalmente lido e a partir de cuja interpretação foram extraídas as conclusões presentes neste trabalho: "as being-with, Dasein 'is' essentially for-the-sake-of others" (HEIDEGGER, 2008b, p. 160).

${ }^{31} \mathrm{O}$ conceito de comunitarismo ontológico é desenvolvido por Charles Taylor, sendo que, para Taylor, uma comunidade é um grupo social constituído por significados comuns, por um comprometimento com os mesmos pontos de referência, como a liberdade, por exemplo, para os americanos.

${ }^{32}$ Assim, pessoas que se encontram faticamente isoladas também são-com-os-outros, uma vez que o ser-um-como-outro não equivale ao ser-aí fático dos outros. Estar sozinho é, portanto um modo específico de ser-um-com-ooutro. O ser-um-com-o-outro não advém pela primeira vez ao dasein por meio de uma parição fática dos outros.
} 
O comunitarismo, nesse sentido, pode não ser necessário, mas é evidente que para que a comunidade e a sociedade humanas sejam possíveis em suas diversas variações, estágios e graus de autenticidade, duração e fugacidade, é necessário que o dasein como tal seja por si mesmo um ser-com (HEIDEGGER, 2008b, p. 150). A imersão no mundo social é um pressuposto mais profundo e amplo para a noção de comunidade.

Por conseguinte, a imersão do eu no mundo social não é uma tese a respeito da interdependência física de substâncias, mas sim uma tese fenomenológica de como estou descerrado para mim mesmo. Contudo, a imersão no mundo social ocorre em geral na medianidade, que Heidegger (2008d, p. 87) descreve como: "o modo indeterminado em que, numa primeira aproximação e na maior parte das vezes, ele [dasein] se dá". Medianidade constitui um pano de fundo que não só é típico da vida humana, mas em termos do qual as condições excepcionais da vida humana fazem sentido, como, por exemplo, o isolacionismo que em geral se dá por conta de uma reação contra o modo de vida dos outros, que é tipicamente padronizado. Mesmo o isolacionismo envolve o cuidado com os outros, tendo em vista que é motivado por uma reação contra os outros, leva em conta os outros como entes humanos que influem na existência desse alguém em questão.

Além de tudo, a imersão no mundo social que se dá na medianidade exige certa abdicação da individualidade e da liberdade, porque não possuo a mim mesmo, mas antes estou disperso no público. Heidegger contrapõe essa dispersão à autenticidade, que constitui um empoderamento de si mesmo. Simplesmente por sermos humanos, temos de realizar a escolha entre a dispersão e a autenticidade. Desse modo, em geral o mundo compartilhado que Heidegger descreve é compartilhado não por pessoas definidas, mas por pessoas que estão aí no cotidiano. Assim, os outros são no cotidiano o neutro, o impessoal.

O horizonte social compartilhado, o ser-com, não é constituído de um grupo definido, mas por uma estrutura social que articula o contexto referencial da significância do mundo. Assim, o modo como as coisas estão em questão para nós é governado pelos padrões sociais em que vivemos. Tudo que está dentro desse padrão é imediatamente entendido por nós e tudo que foge a esse comportamento típico requer interpretação, como se tivéssemos uma série de expectativas e tudo que as quebra nos pega desprevenidos.

Qualquer forma de desvio, portanto, é conspícua e nos perturba. Em geral tentemos a suprimir o desvio. Contudo, no ser-com público e medíocre, a supressão de desvios significa a sujeição aos outros e dos outros. Assim, estamos tão sujeitos às tentativas de supressão dos 
desvios por parte de outros que acabamos por suprimir os desvios de nós mesmos. Desse modo, desembocamos na normalidade que a vida humana adquire, na medianidade.

O predomínio da medianidade pela supressão do desvio reduz a ocorrência de comportamentos bizarros, mas também inibe a conquista e a grandeza:

Toda primazia é silenciosamente esmagada. Tudo que é originário se vê, da noite para o dia, nivelado como algo de há muito conhecido. O que se conquista com muita luta torna-se banal. Todo segredo perde sua força. $\mathrm{O}$ cuidado da medianidade desvela também uma tendência essencial da presença, que chamaremos de nivelamento de todas as possibilidades do ser (HEIDEGGER, 2008d, p. 184).

O fenômeno do nivelamento nem sempre é silencioso, mas às vezes muito barulhento e violento também. As mesmas forças que tornam a vida humana reconhecível para nós e nos permite um mútuo entendimento sem grandes dificuldades geram uma forma de conformismo e supressão social. Segundo o pensamento de Zygmunt Bauman (1998, p. 21):

\begin{abstract}
No mundo moderno, notoriamente instável e constante apenas em sua hostilidade a qualquer coisa constante, a tentação de interromper o movimento, de conduzir a perpétua mudança a uma pausa, de instalar uma ordem segura contra todos os desafios futuros, torna-se esmagadora e irresistível. (...) $\mathrm{O}$ mundo retratado nas utopias era também, pelo que se esperava, um mundo transparente - em que nada obscuro ou impenetrável se coloca no caminho do olhar; um mundo em que nada estragasse a harmonia; nada 'fora do lugar'; um mundo sem 'sujeira'. Um mundo sem estranhos.
\end{abstract}

A supressão dos estranhos e diferentes foi violenta em muitos momentos, que são identificados como momentos em que houve completa desconsideração dos direitos humanos, como nos regimes totalitaristas, na formação dos modernos Estados-nação após a Primeira Guerra Mundial e mais recentemente na Guerra da Bósnia (limpeza étnica) e em outros conflitos como o Genocídio em Ruanda (somente para citar alguns exemplos emblemáticos). Vejamos a interpretação de Arendt (2007b, p. 335) que muito contempla a teoria de Heidegger:

A razão pela qual comunidades políticas altamente desenvolvidas como as antigas cidades-Estados ou os modernos Estados-nações, tão freqüentemente insistem na homogeneidade étnica é que esperam eliminar, tanto quanto possível, essas distinções e diferenciações naturais e onipresentes que, por si mesmas, despertam silencioso ódio, desconfiança e discriminação, porque mostram com impertinente clareza aquelas esferas onde o homem não pode atuar e mudar à vontade, isto é, 
os limites do artifício humano. O "estranho" é um símbolo assustador pelo fato da diferença em si, da individualidade em si, e evoca essa esfera onde o homem não pode atuar nem mudar e na qual tem, portanto, uma definida tendência a destruir. (...) Sem dúvida, onde quer que a vida pública e a sua lei da igualdade se imponham completamente, onde quer que uma civilização consiga eliminar ou reduzir ao mínimo o escuro pano das diferenças, o seu fim será a completa petrificação; será punida, por assim dizer, por haver esquecido que o homem é apenas o senhor, e não o criador do mundo.

Desse modo, se a violação a direitos humanos é identificada com a completa supressão das diferenças que emanam dos indivíduos e dos povos, pode-se afirmar, por conseguinte, que o ideal de igualdade não se realiza com a supressão das diferenças. Nas palavras de Comparato (2006, p. 369):

Como bem salientou Hannah Arendt, o ideal burguês da igualdade formal perante a lei, levado às suas últimas conseqüências, preparou de certa forma a massificação geral da sociedade, em que as diferenças de gênero, raça, tradição cultural ou nacionalidade são inteiramente apagadas, para que o Leviatã pudesse, doravante, torturar e matar a seu bel-prazer, como divindades de antanho.

Nesse sentido, como pensar o conceito de igualdade em um contexto em que os estranhos multiplicam-se e desdobram-se em diversas categorias? Assim, como continuamos a entender nossas vidas mesmo quando o senso de comunidade se desintegra ou é muito fluido? Como fazemos sentido para nós mesmos e partilhamos da inteligibilidade do que está em jogo nesse contexto?

Primeiramente, a igualdade não requer, embora freqüentemente envolva, um senso de comunitarismo. Nesse sentido, o mundo não precisa ser nosso, mas sim compartilhado no sentido de um ser-com visto anteriormente. Em segundo lugar, é preciso que os indivíduos sejam capazes de identificar o outro como parte da mesma humanidade que eles próprios e como entes que possuem uma importância para a determinação de quem eles próprios são. Em terceiro lugar, como quem, em geral, vive na medianidade não é um indivíduo autônomo, mas um integrante do impessoal, é necessário que se permita que o outro seja autêntico em sua existência, ou seja, o direito da igualdade encontra sua realização justamente por permitir o direito à liberdade, que possui sua expressão máxima na autenticidade. Por outro lado, o próprio caminho para a identidade autêntica passa pela igualdade. 
Da fundamental imersão no mundo social extrai-se que, quando nos concebemos como seres humanos, devemos conceber outros seres humanos como parte da mesma humanidade que nós, porque nosso ser implica em suas vidas na mesma medida em que o ser dos outros implica nas nossas. Essa mútua implicação e o compartilhamento do mundo e da verdade criam o conceito de uma condição humana compartilhada pelos mais e pelos menos favorecidos. Todos eles vivem no-mundo-com os outros.

Existem diversas maneiras de se experimentar os outros, o tu. Primeiramente, o outro não é um objeto, mas se comporta ele mesmo, como vimos, com relação ao mundo, por isso mesmo a própria experiência do tu difere das demais experiências porque este possui o caráter de pessoa semelhante ao do eu. Um dos tipos de experiência é o conhecimento do outro como um meio para nossos fins. A esse respeito escreve Heidegger (2008a, p. 82):

(...) até os entes que não são destituídos de mundo - o próprio Dasein, por exemplo - estão presentes à mão 'no' mundo, ou, mais precisamente, podem ser tomados meramente como entes à mão. Pra tanto, deve-se ignorar ou deixar de ver o estado existencial de ser-em. Mas o fato de o Dasein ser tomado como algo que está à mão e unicamente à mão, não é para ser confundido com um modo de "ser simplesmente dado" que é próprio do Dasein (tradução livre da autora) ${ }^{33}$.

Segundo Gadamer (2007a, p. 468), esse comportamento com relação ao tu significa a referência ao egoísmo puro e simples, e não é isso, certamente que a dimensão ética do ser-um-com-o-outro preconiza. Assim, considerar alguém como um objeto físico, como um corpo somente, é desconsiderar seu estado existencial. Nesse caso, estar-se-ia deixando escapar o que faz daquela vida ser a vida que é. Pode-se ter uma atitude científicadescritiva que conhece as propriedades físicas e indiferentes das pessoas ou, uma atitude existencial, que conhece o modo como as pessoas são no mundo. Assim, a maneira adequada de se compreender uma pessoa no seu verdadeiro modo de ser, ou seja, não como um instrumento, seria semelhante à hermenêutica, ou seja, em um processo dialógico. Certamente que não tratamos aqui de uma compreensão científica, mas do cuidado e da preocupação que temos em nosso cotidiano, em nossa vida prática.

\footnotetext{
${ }^{33}$ Segue a versão em inglês na qual o texto foi originalmente lido e a partir de cuja interpretação foram extraídas as conclusões presentes neste trabalho: “(...) for even entities which are not worldless - Dasein itself, for example - are present-at-hand 'in' the world, or, more exactly, can be taken as merely present-athand. To do this, one must completely disregard or not see the existential state of being-in. But the fact that 'Dasein' can be taken as something which is present-at-hand and just present-at-hand, is not to be confused with a certain way of 'presence-at-hand' which is Dasein's own" (HEIDEGGER, 2008a, p. 82).
} 
Portanto, a segunda maneira de experimentar e compreender o tu consiste em reconhecê-lo como pessoa, em uma relação dialética. Assim, a relação eu-tu não seria imediata, mas sim reflexiva, ou seja, seria uma relação em que cada parte salta reflexivamente sobre a outra (GADAMER, 2007a, pp. 468-469). Esse salto, contudo, exige uma abertura para o outro; assim, na medida em que procuramos o reconhecimento do outro somos obrigados a reconhecê-lo. E esse reconhecimento e essa abertura são reflexivos porque sempre o conhecimento do outro acaba sendo um modo de referência a nós mesmos, uma vez que buscamos a nós mesmos no outro e compreendemos mais sobre nós. Assim, o caminho da liberdade e da autenticidade é trilhado a partir do outro.

No momento em que se percebe que, quando a relação com o tu perde aquele caráter útil e imediato da instrumentalidade, encontramos o caminho para nossa própria identidade autêntica, ficando fácil de conciliar nossa pretensão de liberdade e autenticidade à igualdade e ao reconhecimento do outro como pessoa. A busca de si mesmo passa, portanto, pelo reconhecimento do outro e é nesse sentido que liberdade e igualdade convergem.

Esse reconhecimento do outro como parte da mesma humanidade que nós mesmos impede que esse tu seja visto como supérfluo, como ocorreu no Holocausto, por exemplo. A própria forma como me comporto com relação ao outro e ele comporta-se em relação a mim está em questão para minha identidade. Desse modo, não posso simplesmente aniquilá-lo, utilizá-lo como instrumento, ou reduzi-lo a um objeto de cálculo - o que eu reconheço que o outro não é.

Heidegger desenvolve um ideal de vida humana - autenticidade - no qual vivemos de acordo com nossa estrutura ontológica subjacente. Na maior parte das vezes vivemos apartados de nós mesmos, não pertencemos a nós mesmos. A maioria das pessoas passa a vida toda sem ter de enfrentar a questão de se empoderar ou não da sua própria vida. Tendo sido despertado para o desafio existencial, contudo, não se pode retornar ingenuamente para o cotidiano.

A imersão no impessoal degrada não só o entendimento da vida e do mundo de outrem, mas também o entendimento de sua própria vida. Assim, o público

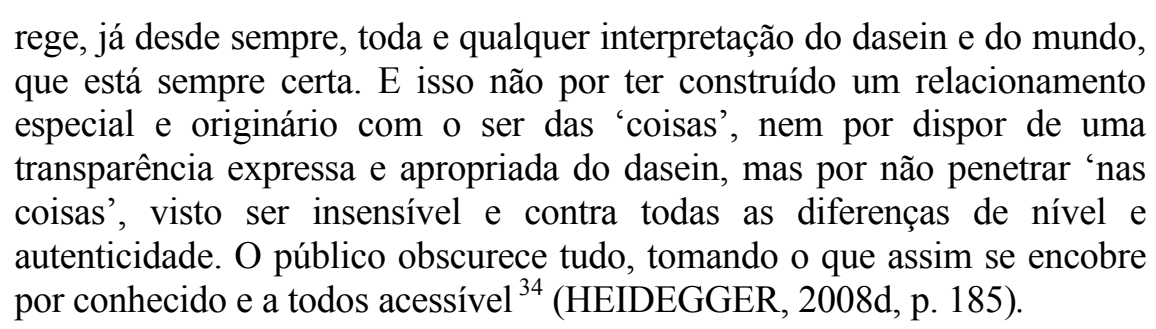

\footnotetext{
${ }^{34}$ Realizamos algumas alterações na tradução para o português para adequar-se melhor à tradução para a língua inglesa de John Macquarrie e Edward Robinson.
} 
Fica fácil de compreender, assim, o perigo que uma publicização de todas as instâncias da vida humana pode trazer. Fica fácil compreender como a população alemã, por exemplo, aderiu a práticas como a delação sistemática e à desconfiança mútua crônica. O apoio da população deu-se em parte porque a ideologia do partido foi incorporada ao público e à medianidade em substituição aos valores tradicionalmente construídos e em parte porque a grande massa do povo vivia no embrutecimento causado pelo impessoal e não tolerava manifestações de autenticidade. Conforme Comparato (2006, p. 372): “Característica marcante do Estado totalitário é a compactação da massa populacional num todo passivo e uniforme, com a conseqüente abolição não só da cidadania, mas da própria autonomia individual."

Quando somos despidos dessa confiança em um mundo que foi publicamente interpretado, somos deixados com o nosso ser-possível, ou seja, com nossa existência, com o chamado para tomarmos uma posição em quem nós somos. Todavia, para podermos responder à questão da identidade é preciso que estejamos envolvidos em um contexto social $^{35}$ com outros que estão igualmente constituindo a si mesmos conforme seguem determinadas possibilidades. O dasein, portanto, não pode ser alguém fora de um contexto social e a autenticidade somente é possível em um contexto dialógico. Maman (2003, pp. 58-59) possui um entendimento semelhante de que só uma sociedade igualitária em condições e oportunidades pode permitir o exercício da liberdade como forma de realização das potencialidades humanas. Assim, o homem livre não é aquele que possui a liberdade do século XVIII, quando o indivíduo é livre em contraposição ao poder e ao arbítrio do Estado. Na totalidade dessa liberdade, onde cada qual tem seu âmbito, ele e os outros decidem sobre o comum projeto de vida, no co-existir social, e onde também não se excluem os projetos individuais.

Enfrentar a vulnerabilidade humana frente a um mundo que pode nos roubar quem nós fôramos a ponto de nos "tornarmos impossíveis", ou pode desaprovar quem somos ou queremos nos tornar, requer uma coragem existencial. Existem muitas forças que nos prendem a quem temos sido ou a como temos vivido; e o impessoal é uma das maiores, tendo em vista que acomoda o dasein com relação ao seu ser, tornando a vida inautêntica mais fácil. Sustentar quem você é, quando seu modo de ser afasta-se das expectativas sociais dominantes significa divergir e o impessoal tentará suprimir o seu desvio, enquadrá-lo. Quando vacilamos em face das críticas às nossas decisões, perdemos poder

\footnotetext{
${ }^{35}$ Não necessariamente na medianidade.
} 
em relação a quem nós somos. O direito à liberdade deve ser entendido, portanto, como um direito à autenticidade.

Quando se garantem condições para o empoderamento (do seu próprio ser), quando são garantidas condições para a autenticidade que se insere em um contexto social de igualdade nos termos propostos, está-se realizando os direitos humanos à igualdade e à liberdade. Como visto anteriormente, a liberdade é essencial ao ser humano entendido como ente humano existente (dasein) e essa liberdade realiza-se na determinação da identidade à medida que vivemos nossas vidas. O ente humano existente, contudo, tem o modo de ser do ser-com, que determina que quem o dasein é, sua identidade, está entrelaçado com a identidade dos outros, porque estes partilham o mundo e a verdade. Contudo, o ser-com e a questão acerca da identidade podem ser definidos com base no cotidiano e no impessoal, o que limitaria consideravelmente as possibilidades de ser do dasein.

Os direitos humanos, portanto, consistiriam em promoção de condições e garantias legais para que o dasein pudesse escolher e realizar sua identidade em uma ampla gama de possibilidades, que comportasse também a escolha pela autenticidade, que seria o ideal de vida humano buscado por esses direitos. Os direitos à liberdade e à igualdade adquiririam um novo significado. A igualdade abandonaria o seu cerco formal para se concretizar materialmente. Todavia, essa concretização dependeria da abertura e reconhecimento do outro que se dá a partir do diálogo, e da conseqüente preocupação com ele. A liberdade, por seu turno, deixaria de partir do pressuposto da livre disposição da natureza e do outro, que conhecemos na medida em que pretendemos controlar, e tornar-se-ia a possibilidade de uma projeção de nossa própria identidade autêntica para além da opinião pública e das contingências. No entanto, a realização de nossa própria identidade rumo às possibilidades e acima do mundo circundante dependeria de alguns fatores. Primeiramente, da ampliação da compreensão e, portanto, do horizonte e da visão de mundo dos indivíduos, que refletiria diretamente na investigação acerca de sua identidade e do papel a ser desempenhado por estes no mundo, para além das possibilidades reservadas a eles pelo impessoal e pela opinião pública. Em segundo lugar, dependeria das devidas condições sociais e materiais para a realização desse projeto de identidade. Como diria Borges (2001, p. 113) em seu conto $O$ Zahir: 
Dobrei; a esquina me indicou, de longe, que o armazém estava fechado. $\mathrm{Na}$ rua Belgrano tomei um táxi. Insone, possesso, quase feliz, pensei que não existe nada menos material que o dinheiro, já que qualquer moeda (uma moeda de vinte centavos, digamos) é, a rigor, um repertório de futuros possíveis. O dinheiro é abstrato, repeti, o dinheiro é tempo futuro. Pode ser uma tarde nos arredores, pode ser música de Brahms, pode ser mapas, pode ser xadrez, pode ser café, pode ser as palavras de Epicteto, que ensinam o desprezo pelo ouro; é um Proteu mais versátil que o da ilha de Faros. É tempo imprevisível, tempo de Bérgson, não o duro tempo do Islã ou do Pórtico. Os deterministas negam que haja no mundo um único fato possível, id est um fato que pôde acontecer; uma moeda simboliza nosso livre-arbítrio (sem grifos no original).

É a partir dessa compreensão, portanto, que se propõem a promoção e efetivação dos direitos humanos, no sentido de possibilitar tanto o reconhecimento do outro e a fusão de horizontes que conduz a esse reconhecimento e a constituição autêntica dos indivíduos.

Arendt (2001) em sua obra $A$ condição humana consegue em certa medida realizar uma proposta de espaço político que garanta a autenticidade, a pluralidade e a igualdade da forma como esse trabalho se propõe a entender os direitos humanos - pensando na teoria de Heidegger de forma mais política. Ela baseou-se em um olhar fenomenológico da vita activa na polis grega para traçar uma teoria acerca de como se daria um espaço político livre e autêntico, em que imperasse a autenticidade e espontaneidade nas ações e discursos dos homens. Disso decorre que a ação política livre não teria uma finalidade determinada, mas seria delineada juntamente com os outros agentes em um espaço dialógico. A existência autêntica dos seres humanos se daria, portanto, na própria vida em comunidade, a partir de sua atuação nesse espaço político que, como veremos no terceiro capítulo pode ser bastante amplo e fluido. A liberdade e a autenticidade do homem se realizariam plenamente nesse âmbito porque o espaço político é o espaço do discurso, sendo que a linguagem é a morada do ser do humano. 


\section{O EXEMPLO LITERÁRIO DE $A$ INVENÇÃO DE MOREL}

Para ilustrar o pensamento desenvolvido no presente capítulo, optamos por uma reflexão guiada pela literatura. Utilizaremos uma obra literária que promove uma reflexão importante acerca do existencialismo e da liberdade dos homens frente a uma realidade dada. Na novela de Adolfo Bioy Casares (2006) intitulada A invenção de Morel, um fugitivo, refugiado em uma ilha aparentemente deserta assiste a uma revelação aterrorizante. Depois de presenciar, por reiteradas vezes, os habitantes da ilha repetirem suas ações, de forma idêntica, semanalmente, o narrador tenta desvendar o mistério da existência daquelas pessoas que não o vêem ou interagem com ele. Escondido em um dos salões da imensa construção que havia na ilha, ouve o discurso de Morel no momento em que expõe aos seus amigos o que engenhosamente construíra: uma máquina capaz de capturar a imagem, cheiro, tato, sons de uma determinada pessoa ou lugar e, projetando-a como um filme absolutamente idêntico e fiel, capaz de imortalizá-la para sempre. Parece uma invenção um tanto quanto benéfica, todavia, algumas inquietações permanecem:

Estava certo de que meus simulacros de pessoas careceriam de autoconsciência (como os personagens de um filme cinematográfico).

Tive uma surpresa: depois de muito trabalho, ao congregar esses dados harmonicamente, encontrei pessoas reconstruídas que desapareciam se eu desconectava o aparelho projetor, viviam apenas os momentos passados em que se gravara a cena e, ao terminá-los, voltavam a repeti-los, como se fossem partes de um disco ou de um filme que, uma vez terminado, tornasse a começar, mas que ninguém poderia distinguir das pessoas vivas (parecem circular em outro mundo, fortuitamente abordado pelo nosso). Se atribuímos consciência e tudo o que nos distingue dos objetos às pessoas que nos rodeiam, não poderemos negá-la àquelas criadas por meus aparelhos com nenhum argumento válido e exclusivo.

Congregados os sentidos surge a alma. Era de se esperar. (...)

Para fazer reproduções vivas, preciso de emissores vivos. Não crio vida. (...)

Aqui estaremos eternamente - mesmo que partamos amanhã -, repetindo consecutivamente os momentos desta semana e sem jamais poder sair da consciência que tivemos em cada um deles, pois assim nos gravaram os aparelhos; isso permitirá que nos sintamos numa vida sempre nova, pois não haverá outras recordações em cada momento da projeção salvo aquelas que tivemos no momento correspondente da gravação, e porque $o$ futuro, muitas vezes deixado para trás, manterá sempre seus atributos (CASARES, 2006, pp. 85-92). 
Assim, perguntamo-nos se a vida que levariam as pessoas imortalizadas pela invenção de Morel pode ser chamada de existência, uma vez que nela não há futuro, não há escolha, somente o passado imutável, impossível de ser lido à luz do futuro possível e não realizado. Perguntamo-nos ainda se a existência inautêntica não se assemelha muito à vida dessas imagens que repetem suas ações reiteradas vezes e não escapam ao seu destino, que ficará eternamente vinculado àquela semana vivida e gravada pela máquina.

E por fim, a rejeição da morte, que é a impossibilidade da existência, não seria uma vida inconsciente? Na novela, ao fugir da morte estava Morel precipitando-se justamente a ela, uma vez que encerrou a si próprio e aos seus amigos em uma vida imortal que não pode ser chamada de existência, sendo que o ser não corre livre, projetando-se às possibilidades. Condenou-o e aquelas pessoas à morte e não à vida eterna.

Com esse sucinto exemplo literário procurei mostrar como os indivíduos, embora conscientes, podem estar completamente alheios à sua existência e ao seu ser, enquanto presos ao cotidiano alienante, à medianidade e ao impessoal. 


\section{A PROMOÇ̃̃o E EFETIVAÇ̃̃o dOS DIREITOS HUMANOS POR MEIO DA LITERATURA}

A orientação teórica deste capítulo é que nos conduzirá na investigação ao papel da literatura na promoção e efetivação dos direitos humanos, iluminando-os e inserindo-os em uma compreensão para além de seus valores inertes, trazendo-os à vida: "O problema filosófico dos direitos do homem não pode ser dissociado do estudo dos problemas históricos, sociais, econômicos, psicológicos, inerentes à sua realização: o problema dos fins não pode ser dissociado do problema dos meios" (BOBBIO, 2004, p. 44).

É nesse sentido que o presente trabalho é proposto: no sentido de uma proposta de atualização hermenêutica necessária dos valores dos direitos humanos, que dão origem à sua cultura, e no sentido de uma investigação da literatura como parte dessa cultura enquanto parte da vida vivida e activa dos homens.

No entanto, é essencial que nos questionemos, neste ponto em que delineamos as bases teóricas que guiarão todo o trabalho, o seguinte: a partir do momento em que a Declaração Universal dos Direitos Humanos foi redigida, o que se esperava de seus destinatários?

Inicialmente, como diversos momentos do preâmbulo da Declaração fazem referência ao comprometimento dos Estados em relação aos direitos humanos estabelecido na Carta das Nações Unidas, esperava-se que o parágrafo pragmático da Declaração Universal dos Direitos Humanos orientasse à ação legislativa; como se a Declaração constituísse um padrão a ser seguido nas legislações e codificações por todos os Estadosmembros das Nações Unidas. No entanto, os redatores perceberam que seria mais adequado incorporar princípios relativos aos deveres dos Estados em um novo documento, mais apropriado. Os instrumentos que cumpriram esse papel foram o Pacto Internacional dos Direitos Civis e Políticos e o Pacto Internacional dos Direitos Econômicos, Sociais e Culturais. O fato de que a Declaração não seria legalmente vinculante para os governos fez com que fosse ainda mais necessário que exercesse sobre eles uma grande persuasão moral. Desse modo, a Declaração, em especial seu parágrafo operacional, não deveria ser endereçada aos Estados, mas sim a todos os indivíduos e todas as entidades de todas as sociedades (MORSINK, 1999, p. 320-328).

Abandonada a ação legislativa como o principal objetivo explícito da Declaração, era necessário que os redatores confiassem em seu propósito educativo como a principal razão 
para a proclamação do documento. A Declaração Francesa de 1789 também tinha como objetivo primário educar o povo francês para que dali para frente pudesse julgar se seu Estado ou governo desempenhava as funções para as quais havia sido instituído, qual seja, proteger os direitos humanos do povo francês. Dessa forma, pode-se dizer que a Declaração de 1948 é proclamada como um padrão para os objetivos educacionais explícitos, bem como para os objetivos legislativos nela implícitos (MORSINK, 1999, p. 320-328).

No que concerne à atribuição de direitos humanos inerentes, não há nada a ser atingido ou a ser objetivado, tendo em vista que as pessoas possuem esses direitos desde o nascimento. A Declaração pode servir de norte apenas para que esses direitos possam ser efetivados e gozados por todos os seres humanos. Assim, o documento deveria ser usado como um texto educacional que diria às pessoas os direitos humanos que elas já possuiriam (MORSINK, 1999, p. 320-328).

A conexão entre a Declaração Universal dos Direitos Humanos e a educação em direitos humanos é ainda maior do que a Resolução $\mathrm{n}^{\circ} 184^{36}$ sugere: não somente o artigo 26 da Declaração faz dos direitos humanos um objetivo educacional, mas a educação em direitos humanos em si é o primeiro e principal propósito da Declaração Universal como um todo. Acerca do artigo 26, podemos observar que segundo parágrafo é tão importante quanto o primeiro, tendo em vista que estabelece qual o espírito que governa a educação pretendida com a Declaração (NAÇÕES UNIDAS, 1948):

\section{Art. XXVI}

2. A instrução será orientada no sentido do pleno desenvolvimento da personalidade humana e do fortalecimento do respeito pelos direitos humanos e pelas liberdades fundamentais.

Não podemos deixar de mencionar, ainda, a recentíssima minuta de Declaração sobre Educação e Treinamento em Direitos Humanos da Organização das Nações Unidas ${ }^{37}$ (Recomendação $n^{\circ}$ 4/2 do Comitê de aconselhamento do Conselho de Direitos Humanos na ONU, de 29 de janeiro de 2010); elaborada a partir das Resoluções $n^{\mathbf{0}}$ 06/10, de 28 de setembro de 2007 e n 10/28 de 27 de março de 2009 do Conselho de Direitos Humanos. Esta minuta reforça ainda mais a interpretação da educação não somente como um direito

\footnotetext{
${ }^{36}$ Em março de 1993, a Comissão de Direitos Humanos recomendou que a ONU proclamasse uma década de educação em direitos humanos. A Assembléia Geral aceitou a idéia em dezembro de 1994 e adotou a Resolução no 184 que proclamou a década 1995-2005 como a Década das Nações Unidas para Educação em Direitos Humanos.

${ }^{37}$ Draft United Nations declaration on human rights education and training.
} 
humano, mas como um meio de promoção e garantia do respeito aos direitos humanos. A minuta faz referência explícita ao artigo 26 da Declaração Universal de Direitos Humanos e orienta os Estados a garantirem que a educação seja direcionada ao fortalecimento do respeito aos direitos humanos e às liberdades fundamentais. A educação em direitos humanos, conforme o preâmbulo da minuta, deve buscar o entendimento comum e a sensibilização a partir de uma visão que fortaleça o comprometimento universal com os direitos humanos.

Por conseguinte, estabelecer que todos os seres humanos têm direito à educação não é suficiente se não definimos o espírito dessa educação. Para que o objetivo de incorporar os direitos humanos enquanto ética na vida dos homens seja alcançado, o espírito mais adequado à sua educação consiste na formação (bildung), que, como o todo da Declaração Universal dos Direitos Humanos, em especial seu parágrafo $2^{\circ}$, coloca o desenvolvimento dos seres humanos em primeiro lugar.

Quando nos referimos à formação, tratamos de algo bem diverso da cultura no sentido de aperfeiçoamento de faculdades e de talentos, tendo em vista que falamos de algo mais elevado e mais íntimo, de um modo de ver e de conhecer o mundo, de uma visão que dissemina o empenho espiritual e moral na sensibilidade e no caráter. O resultado da formação, portanto, não se produz na forma de uma finalidade técnica, mas nasce do processo interior de formação, do devir e da ética.

Na formação, é possível apropriar-se totalmente daquilo que em que e através do que alguém é instruído. Nesse sentido, tudo que ele assimila, integra-se nele. Mas na formação aquilo que foi assimilado não é como um meio que perdeu sua função. Na formação adquirida nada desaparece, tudo é preservado. A formação é um conceito genuinamente histórico, e é justamente o caráter histórico da conservação o que importa para a compreensão da filosofia, da literatura e dos direitos humanos, uma vez que o ser do espírito humano está essencialmente vinculado à idéia de formação (GADAMER, 2007a, pp. 44-47).

Para os gregos, a formação dava-se por meio da paidéia ${ }^{38}$, em que a descoberta do homem não é a do eu subjetivo, mas sim uma empreendida por meio da educação de acordo com o autêntico ser do homem. O conceito socrático de fim da vida nos orienta para a verdadeira essência da educação, que é dar ao homem condições para alcançar o fim autêntico de sua vida, seus projetos, e isso não pode ser alcançado somente nos poucos

\footnotetext{
${ }^{38}$ Segundo Werner Jaeger (1986), era o processo de educação em sua forma verdadeira, a forma natural e genuinamente humana na Grécia antiga.
} 
anos de uma educação superior. Assim, a educação não deve restringir-se à infância e à juventude, devendo prolongar-se como formação durante toda a vida dos homens, convertendo-se na aspiração de uma ordenação filosófica consciente da vida, que se propõe a cumprir aquele destino. O homem, assim concebido, nasceu para a paidéia. Por isso, em contextos em que imperam forças que ameaçam violar a liberdade interior, a paidéia tornase um forte inviolável para a luta em prol dessa liberdade (JAEGER, 1986, p. 394).

Além disso, a formação pressupõe um alheamento, a busca de componentes alheios ao imediato e a nós próprios, com o reconhecimento e apropriação do que é estranho, reconhecendo nele o que é próprio, familiarizando-se com ele. "Eis o movimento fundamental do espírito, cujo ser é apenas o retorno a si mesmo a partir do ser-outro" (GADAMER, 2007a, p. 50).

Assim, cada indivíduo está sempre em processo de expansão, de superação da naturalidade através da formação, sendo que o mundo cresce e pluraliza-se humanamente em linguagem e costumes. O desafio proposto aos direitos humanos é o de fazer compreender essa diversidade e pluralidade, a partir de um conceito de educação que se incorpore permanentemente à vida e ao ser dos indivíduos, que não seja passageiro: a formação. Por conseguinte, o que perfaz a formação não é o alheamento como tal, mas sim o retorno a si, que pressupõe o alheamento.

Nesse sentido, portanto, a formação é uma elevação para o universal, todavia, não como a universalidade pretendida pela razão, mas como visão dos nossos fins privados com certo distanciamento, como os outros o vêem. Assim, os pontos de vista universais para os quais nos mantemos abertos na formação não se tratam da determinação do particular pelo universal, de uma fórmula ou método para se chegar à verdade, mas são, simplesmente, pontos de vista de possíveis outros, que alçam mais a universalidade ao comunitário do que a um padrão fixo de validade.

Concluindo, sendo a educação o caminho indicado pela Declaração Universal dos Direitos Humanos para a promoção desses direitos, propõe-se que ela seja empreendida como formação, que é apropriada pelos indivíduos e se incorpora em sua vita activa, na existência e na ética, contribuindo para que realizem sua liberdade e seus projetos de vida. Essa é a principal forma pela qual a efetivação dos direitos humanos deixará de ocorrer em uma plataforma teórica e formal, passando a incorporar-se nos indivíduos, através da vida que eles constroem e do seu modo de ser. 
Isso nos leva a perguntar: a literatura tem uma função formativa de tipo educacional? Sabemos que a instrução de tradição humanista sempre se baseou nas letras. Daí o elo entre formação do homem, humanismo, letras humanas e o estudo da língua e da literatura. Seja como for, sua função educativa é muito mais complexa do que pressupõe um ponto de vista estritamente pedagógico: A literatura pode formar, mas não segundo a pedagogia oficial, que
costuma vê-la ideologicamente como um veículo da tríade famosa - o
Verdadeiro, o Bom, o Belo, definidos conforme os interesses dos grupos
dominantes, para reforço de sua concepção de vida. Longe de ser um
apêndice da instrução moral e cívica (esta apoteose matreira do óbvio,
novamente em grande voga), ela age com o impacto indiscriminado da
própria vida e educa como ela - com altos e baixos, luzes e sombras
(CANDIDO, 2002, p. 83).

Assim, mesmo as obras consideradas indispensáveis para a educação formal nas escolas trazem freqüentemente o que as convenções desejariam banir. A formação proporcionada pela literatura autêntica é relacionada com a palavra e com linguagem e, portanto, com as concepções de mundo estranhas, sendo continuação de um processo de formação baseado na superação do mundo circundante e na familiarização com o outro, na construção de nossa própria liberdade ao conhecimento a partir do ser-outro, do reconhecimento.

Assim, a forma de realização dos direitos humanos pretendida pela Declaração Universal, em sua proposta formadora de cada indivíduo ou grupo, independentemente do Estado a que está vinculado, extrapola a imagem simplista de um Estado como organismo que estabelece as regras do jogo, que codifica, coage e sanciona, contribuindo para uma justiça dogmática. Essas técnicas limitadas dos Estados, que visam à instituição de obrigações, estão fadadas a atingir objetivos igualmente limitados (BOBBIO, 2007).

Dessa forma, a Declaração Universal dos Direitos Humanos orienta para uma nova forma de controle social, distinta daquelas ações de controle do Estado liberal clássico: o emprego cada vez mais difundido das técnicas de encorajamento em acréscimo, ou em substituição, às técnicas tradicionais de desencorajamento. Portanto, a promoção e a efetivação dos direitos humanos realizada por meio da formação e da literatura nos faz caminhar para o abandono da imagem tradicional do direito como ordenamento protetorrepressivo. 
A aplicação do direito não é meramente declaratória e reprodutiva de um direito positivo. Essa aplicação seria constitutiva e produtiva de um direito atualizado, que abarca o fato social e suas atualizações. O direito positivo contemporâneo deixou de ser um instrumento de controle social stricto sensu para se tornar um instrumento de direção social. Trata-se, portanto, de um direito promocional que almeja estimular comportamentos por meio de medidas diretas ou indiretas. Considerando também o critério da efetividade, um direito promocional não pode restringir-se ao alcance da validade formal; procurandose avaliar também a conduta dos destinatários das normas ${ }^{39}$.

Nesse ponto, o Estado adquire cada vez mais a função de promover, em vez de tutelar (ou garantir) coativamente os direitos, criando condições propícias para que o direito possa se efetivar. É importante ressaltar que a essência do poder seria estranha à polis grega. A essência do poder, como no pensamento moderno acerca do Estado, é fundada na pressuposição metafísica de que a essência da verdade transformou-se em certeza, isto é, na autocerteza da essência humana que se assegura em si mesma, e que a essência da verdade se baseia na subjetividade da consciência. Essa pressuposição é refletida na autoridade do Estado enquanto imperium, no sistema jurídico positivista, fechado, repressivo e que exige ações conformes. A efetivação dos direitos humanos aqui proposta, pelo contrário, não ocorre por meio do poder, ou sequer diretamente por intermédio da tutela do Estado, mas sim da própria vida e da palavra, porque só por meio da palavra o ser revela.

Sendo o sistema internacional de direitos humanos um sistema mais aberto do que fechado, em que ao jurista ${ }^{40}$ é atribuída a tarefa de colaborar com o legislador e com o juiz para a construção de um novo direito, não somente o jurista, mas todos que propõem formas de promoção e de efetivação dos direitos humanos devem poder colaborar com essa construção. Dessa forma, os direitos humanos passam a reconhecer que vivemos em uma sociedade em constante transformação, em que irrompem fatores que rapidamente tornam

\footnotetext{
${ }^{39}$ Para a diferenciação do que é ou não direito o critério da efetividade desempenha um importante papel. Essa importância destaca-se principalmente no Direito Internacional Público, que abrange os direitos humanos, tendo em vista a descentralização do poder que dá ensejo a diversos conflitos entre o fato e o direito.

${ }^{40}$ Nessa perspectiva, a tarefa do jurista não é mais a interpretação histórica de um direito já construído, mas a pesquisa de um direito em construção, não tanto a convalidação, com base em uma análise das fontes formais do direito que é, mas a legitimação, com base nos princípios materiais da justiça, do direito que deve ser. Esse questionamento das fontes formais do direito é acompanhado da importância cada vez maior dada às chamadas fontes extralegislativas (ou, até mesmo, extra-estatais). Um dos dogmas do positivismo jurídico em sentido estrito foi que a fonte principal do direito no Estado moderno fosse a lei, isto é, a norma presumidamente geral e abstrata posta por um órgão específica e exclusivamente competente. Assim, o direito passa a poder ser criado na existência de cada indivíduo.
} 
inadequados os modelos tradicionais, entre os quais está o conjunto de regras e valores transmitidos. Assim sendo, o referido sistema precisa permitir que incida sobre ele e em sua própria criação uma interpretação constante, criativa, que atente para a temporalidade da história e para o caminho da existência humana.

O que importa verdadeiramente compreender é que as boas leis não são capazes por si mesmas de tornar melhores o Estado ou os cidadãos. Caso contrário, seria fácil infundir, com a letra da lei, a determinação de um Estado a todos os restantes. A formação deve atuar por meio da livre vontade dos cidadãos e não por meio de um amontoado cada vez maior de leis especiais para cada setor da existência.

A promoção, por conseguinte, realiza-se quase sempre por medidas positivas, de estímulo ou incentivo. No caso, o ato de ler ou de escrever tanto já é a realização do próprio direito, como também uma forma de facilitar e viabilizar indiretamente a efetivação dos direitos humanos na vida dos leitores ou escritores. Indiretamente, ainda, reflete em todo espaço público, em toda a sociedade, tornando possível um espaço político, público, que comporta o discurso espontâneo e livre. A leitura e, especialmente, a escrita constituem formas de encorajamento, na medida em que incitam a transformação do status quo, a superação da realidade e sua transformação autêntica, mais do que a manutenção de comportamentos desejáveis e previsíveis.

É importante destacar que no caso da liberdade, contudo, é muito difícil enquadrá-la em um comportamento desejável a ser facilitado e estimulado. Talvez esse direito corresponda à autenticidade, enquanto comportamento autêntico. Mesmo porque se pode supor um tipo de sociedade em que a "promoção" por meio do condicionamento psicológico dos indivíduos seja tão ampla e eficaz a ponto de tornar supérflua aquela forma de controle considerada, em geral, mais intensa, que é, precisamente, o controle mediante o uso de meios coativos. Portanto, a literatura não pode ser considerada, de maneira alguma um instrumento de efetivação de direitos, mas sim um ente com um ser, realizado a partir dos indivíduos, que, por si só, é um acontecimento emancipador, formador e ético; algo que exprime o homem e depois atua na própria formação do homem (CANDIDO, 2002, p. 80).

Assim, é preciso saber que o povo histórico de poetas e pensadores que pensavam originariamente, autenticamente, já tem sido vitorioso e invencível. Isso enquanto a humanidade não sucumbe ao terrível - sempre ameaçador - desvio e desconhecimento de sua essência (HEIDEGGER, 2008c, p. 115). O destino de ter a palavra é uma distinção essencial da humanidade e pode, sim, ser realizado através da literatura. A literatura, 
portanto, é introduzida em nossa investigação como uma forma de rompimento da barreira entre o espaço político reservado ao âmbito estatal e a sociedade civil, sendo capaz de realizar na vita activa de todos os indivíduos o conhecimento, a autenticidade, o discurso, o diálogo com o outro e com a tradição, criando um espaço político amplo e livre.

$$
* * *
$$


Capítulo II

A Literatura como Fonte de HumanizaÇão e AutentiCidade 
Desordem

meu assunto por enquanto é a desordem

o que se nega

à fala

o que escapa

ao acurado apuro

do dizer

a borra

a sobra

a escória

a incúria

o não caber

( ...)

é próprio da palavra

não dizer

ou

melhor dizendo

só dizer

a palavra

é o não ser

isto porque

a coisa

(o ser)

repousa

fora de toda

fala

ou ordem sintática

e o dito (a

não coisa) é só

gramática

o jasmim, por exemplo,

é um sistema

como a aranha 
(diferente do poema)

o perfume

é um tipo de desordem

a que o olfato

põe ordem

e sorve

mas o que ele diz

excede à ordem

do falar

por isso

que

só

desordenando

a escrita

talvez se diga

aquela perfunctória

ordem

inaudita

(GULLAR, 2010, pp. 26-32).

Se os direitos humanos são entendidos como o empenho para que o homem se torne livre para a sua humanidade, para nela encontrar dignidade, então, delineiam-se também as vias de realização da humanidade e da liberdade (HEIDEGGER, 2005). Antonio Candido denomina esse processo de conquista da humanidade de humanização, que se realizaria a partir do exercício da reflexão, da aquisição do saber, da boa disposição em relação ao próximo, do afinamento das emoções, da capacidade de penetrar nos problemas da vida e do senso da beleza.

A proposta deste trabalho como um todo e, mais especificamente deste capítulo, é procurar traçar qual o papel da literatura na realização dessa humanização e, por conseguinte, da liberdade humana. A autenticidade, como esclarecido do capítulo anterior, é uma das expressões fundamentais da libertação do homem para sua humanidade, e as formas de realização da humanização, enumeradas por Candido, estimulam em maior ou menor medida a procura pela identidade e pela autenticidade. Veremos como a literatura, em seu modo de ser próprio, percorre os caminhos apontados para a humanização. 
Cabe ressaltar, preliminarmente, que trabalharemos num primeiro momento com um conceito de literatura bastante amplo, extraído do texto de Candido (2004, p. 174) intitulado $O$ direito à literatura:

Chamarei de literatura, da maneira mais ampla possível, todas as criações de toque poético, ficcional ou dramático em todos os níveis de uma sociedade, em todos os tipos de cultura, desde o que chamamos folclore, lenda, chiste, até as formas mais complexas e difíceis da produção escrita das grandes civilizações.

Contudo, à medida que as questões forem sendo desenvolvidas na dissertação, serão explorados aspectos da literatura complementares a esse conceito, mesmo porque importa mais a nós descrever a forma como a literatura acontece e se insere no mundo da existência do que fixar um conceito fechado de literatura. A literatura, portanto, por ser produto humano, também é um conceito em formação à medida de sua existência. Assim, a determinação de sua valência ontológica própria somente pode acontecer na medida em que formos trabalhando com esse conceito e testando seus limites.

Como se verá mais adiante existe uma contradição entre os aspectos universalistas e particularistas que orientam a classificação de determinada obra como literatura. Contudo, referida contradição assemelha-se muito àquela existente entre o universalismo e o relativismo nos direitos humanos. Em ambos os casos as incompatibilidades são ilusórias e devem ser superadas, assim como a parte e o todo devem se articular. Segundo Candido (2006a, p. 32), o contraditório é "o próprio nervo da vida".

Além disso, ressaltamos logo de partida que não somente a chamada literatura social, ou dita engajada, seria capaz de realizar a humanidade e liberdade do homem, apesar de se pensar quase que exclusivamente na literatura que parte de uma análise do universo social e que procura retificar suas iniqüidades ${ }^{41}$ quando se trata de uma realidade tão política e humanitária quanto a dos direitos humanos (CANDIDO, 2004, p. 180). Trataremos deste tipo literatura em alguns momentos, todavia, perceberemos que a definição da literatura social é mais adequada a uma perspectiva particularista, que parte da situação histórica e do contexto em que se insere o autor. Depararemo-nos também com vários níveis de ideologia que se pretendem expressar pela literatura, tanto as que influem na forma quanto nas temáticas.

${ }^{41}$ Diríamos no plano consciente do autor, quando este deseja expressamente assumir posição em face dos problemas, como uma função ideológica de sua literatura. 


\section{A literatura SOB O doMínio da OPINIÃo PÚbliCA E A TÊNUE SEPARAÇão da} LITERATURA AUTÊNTICA

Como todo processo comunicativo inter-humano, a produção literária é constituída de três elementos indissoluvelmente ligados: o autor, a obra e o público (CANDIDO, 2006b, p. 32). Desses três elementos extrai-se um quarto: o efeito da obra. A partir desses elementos, procuraremos refletir a respeito dos efeitos derivados da obra literária em seus dois momentos: o de criação e o de recepção.

Acerca do momento de criação refletiremos sobre a literatura enquanto expressão autêntica do artista. Já no momento de recepção o foco será sobre o papel da literatura na formação humanitária e autêntica dos leitores.

Por ser uma expressão de realidades profundamente radicadas no artista, a literatura extrapola a mera transmissão de noções e conceitos (CANDIDO, 2006b, p. 31). Nesse sentido, depende da intuição e da imaginação tanto em sua criação quanto em sua recepção para que se constitua em processos criativos e hermenêuticos autênticos. Todavia, é impossível deixar de perceber a interação da literatura com os valores sociais, ideologias e sistemas de comunicação aos quais recorre o artista, por um lado, e com o público atual ou prefigurado, por outro.

\subsection{O ESCRITOR E A OBRA LITERÁRIA AUTÊNTICOS}

Primeiramente, devemos refletir um pouco acerca da palavra "criação". A criação pressupõe que o criador torna existente aquilo que não existia antes. Remete, evidentemente, à criação divina, assim como Deus criou o mundo a partir do Verbo. $\mathrm{O}$ escritor cria, portanto, um novo mundo a partir de sua decisão de escrever e de sua imaginação (PERRONE-MOISÉS, L., 2006a, p. 100). Trata-se, como veremos mais adiante, do gênio criador. A relação do criador com o divino é aqui pretendida também porque, no pensamento grego originário, a deidade funda-se diretamente no extra-ordinário do ordinário, ou seja, no ser dos entes, sendo que tudo o que pertence ao aparecimento do ser é sempre à maneira do extra-ordinário. Assim, o escritor, quando cria, não cria pura e 
simplesmente um ente, mas, principalmente, constrói um caminho para que possamos chegar aos deuses por meio da palavra (HEIDEGGER, 2008c, pp. 176-177).

Por outro lado, uma importante expressão a ser considerada é a "representação literária", que ao contrário da expressão "criação do texto literário" conduz a algo anterior ao texto, preexistente: um mundo a ser representado. Representação, sem dúvida, é um dos conceitos mais antigos da teoria literária, remetendo à mimese de Aristóteles. A representação supõe assim, um real a ser imitado e transformado como ponto de partida. No entanto, conforme veremos, a literatura jamais consegue ser bem sucedida em representar esse mundo de uma maneira totalizante e, no entanto, acaba desvelando um mundo mais real do que aquele (PERRONE-MOISÉS, L., 2006a, p. 102).

Considerando a literatura como a criação de um mundo ou como a representação que parte do mundo, devemos refletir em que medida o modo de ser da literatura cumpre um ou outro papel. Por um lado, deve-se reconhecer a influência exercida pelo meio social $^{42}$ na obra literária e, por outro, para que a literatura não uma mera cópia e sim arte, $o$ representado (mundo, ideologia, realidade social) deve encontrar um crescimento do ser por meio da palavra escrita (GADAMER, 2007a, p. 201). A partir desse problema nos propomos a investigar como se dá a expressão autêntica do artista.

A atuação dos fatores sociais na criação varia conforme a arte considerada e a orientação geral seguida pelas obras. Assim, as forças sociais condicionantes guiam o escritor em maior ou menor grau (CANDIDO, 2006b, p. 35). Evidentemente que o escritor, como todos os homens, está em situação e é condicionado por ela; mas os seus escritos, como todo projeto humano, devem abranger, particularizar e superar essa situação, até mesmo explicando-a e desvelando-a.

De uma perspectiva sociológica, dir-se-ia que a arte é social porque depende da ação de fatores do meio, que se exprimem em diversos graus de sublimação; e, por outro lado, produz nos indivíduos um efeito que modifica sua conduta e concepção de mundo ou reforça neles o sentimento dos valores sociais. Isso decorreria do próprio modo de ser da obra de arte e independeria da consciência que possam ter os artistas e o público (CANDIDO, 2006b, p. 30).

\footnotetext{
${ }^{42}$ A influência da tradição histórica será abordada em outro capítulo, apesar de reconhecermos que o meio social é fruto também dessa tradição.
} 
Candido fala a respeito de três funções da literatura: a função total, a função social e a função ideológica ${ }^{43}$. Esta última trata de um caráter voluntário da criação e da recepção da obra literária e seria um desígnio consciente do autor, que pode ter base em um sistema de idéias, mas que muitas vezes é desmentido pela estrutura objetiva do que ele escreveu. No caso de haver esse tipo de motivação por parte do autor, a obra é dita interessada. Essa função é geralmente mais clara nas obras de cunho político, religioso ou filosófico (CANDIDO, 2006b, p. 56). Assim, há na literatura níveis de conhecimento intencional, isto é, planejados pelo autor e assimilados pelo receptor; é nesses níveis que o autor injeta as suas intenções de propaganda, ideologia, crença, revolta, adesão etc.

Nos casos em que existem conhecimentos intencionais explícitos (ou implícitos) na obra, os leitores têm a oportunidade de conhecer a sociedade e os sentimentos que a envolvem e de tomar posição em face deles (CANDIDO, 2004, p. 180). Candido bem menciona o exemplo de Castro Alves (1847-1871), autor de uma literatura de caráter ideológico abolicionista que conjuga o conteúdo e a organização formal, o que possibilita uma melhor expressão do sentimento que procura exprimir, juntamente com a natureza de sua posição política e humanitária.

Por outro lado, há a função social das obras, que consiste no papel que a obra desempenha nas relações sociais de determinado povo em determinado período, ao mesmo tempo em que satisfaz necessidades materiais e espirituais. Isso implica a manutenção ou transformação de certa ordem na sociedade. A função social, diferentemente da ideológica, é decorrente da própria "natureza" da obra, sem que haja qualquer intenção do autor em imprimir essa função. Sua inserção em um universo de valores culturais, conjuntamente com seu caráter de expressão e a comunicação que a viabiliza definem esse caráter da literatura (CANDIDO, 2006b, p. 55-56).

Contudo, apesar do influxo exercido pelos valores sociais, ideologias e sistemas de comunicação na obra literária - que nela se transmutam em conteúdo e forma ${ }^{44}$ - o impulso criador do artista é uno (CANDIDO, 2006b, p. 40). A Divina Comédia, por exemplo, teve por base conceitos teológicos, além de formalmente ser constituída por um determinado número de versos e cantos ritualístico, contudo, o crescimento dessa ideologia que foi

\footnotetext{
${ }^{43}$ Neste momento trataremos especificamente das funções ideológica e social. A função total será explicada em um momento mais oportuno.

${ }^{44}$ Conteúdo e forma, na realidade, são absolutamente interdependentes. No limite, a criação poética, onde a literatura alcança o auge de sua capacidade representativa, a palavra, é ao mesmo tempo forma e conteúdo. Aqui, portanto, a estética não se separa da lingüística (CANDIDO, 2006b, p. 32).
} 
possível na representação garantiu a autenticidade e perpetuação da obra. Isso significa que o artista criador é determinante para a literatura. Em alguns momentos, porém, a literatura é tão inautêntica, o escritor é a tal ponto identificado às aspirações e valores de seu tempo, que parece dissolver-se nele, perdendo sua identidade (CANDIDO, 2006b, p. 35). Mesmo porque sempre foi tática muito comum das elites ideológicas, tendo reconhecido o perigo, subvencionarem o artista para controlar-lhe o poder de destruição (SARTRE, 2006, p. 66).

Existem momentos em que, inclusive, a predominância da ideologia é mais valorizada do que a qualidade representativa das obras. Para o regime soviético a literatura autêntica era aquela que descrevia as lutas do povo, cantava a construção do socialismo ou celebrava a classe operária. Assim foi também nas décadas seguintes à independência do Brasil, em que a tentativa de criação de uma literatura nacional passava pela valorização da obra cuja temática e os cenários fossem particularmente brasileiros, em detrimento, algumas vezes, da imaginação do artista, da qualidade estética e de uma maior autenticidade da obra. Na efetivação dos direitos humanos também se corre esse risco, qual seja, de afirmar que a literatura só alcança a verdadeira função quando é social. Tais critérios não são de forma alguma suficientes para classificar uma obra literária como uma produção autêntica, mesmo porque ignoram o verdadeiro modo de ser da literatura que é gratuita e desinteressada (CANDIDO, 2004, p. 181).

Neste ponto, devemos destacar que há muito tempo se percebe que o domínio de determinadas formas de expressão reside, nos tempos modernos, na singular ditadura da opinião pública. A opinião pública é a instauração da dominação, com a objetivação de tudo, inclusive das manifestações artísticas. Por isso a linguagem é utilizada a serviço da mediação das vias de comunicação - nas quais se espraia a objetivação, com o acesso uniforme de tudo para todos - caindo sob a ditadura do impessoal. Ela decide previamente o que é compreensível e o que deve ser desprezado como incompreensível.

Leyla Perrone-Moisés (2006b) observa que entre 2001 e 2002 houve o "desaparecimento" da disciplina literatura no ensino médio de vários estabelecimentos brasileiros. Segundo os documentos do Ministério da Educação brasileiro, a área antes denominada Língua e Literatura passou a se chamar Linguagens, Códigos e suas Tecnologias, denotando que a literatura não é mais lida e estudada nas disciplinas e que a língua portuguesa foi reduzida a um mero código, equiparável aos códigos de trânsito. Além disso, o domínio desses códigos não mais é considerado como sendo da ordem do 
conhecimento, mas da tecnologia. Assim, a literatura foi absorvida pela técnica e é tida como instrumento de objetivação e controle da sociedade e da natureza.

Por outro lado, é oferecido ao aluno o incentivo à constituição de sua identidade. Todavia, para tanto, o "conservadorismo de determinados pontos de vista devem ser abandonados" e deve-se "procurar a herança do agora" (PERRONE-MOISÉS, L., 2006b, p. 21). Nas palavras de Leyla Perrone-Moisés (2006b, p. 21), "pobre aluno a quem não se oferece nenhum ponto de partida sólido para sua escolha individual", ou seja, a partir de que linguagem o aluno poderá operar essa busca? A resposta: a partir da linguagem técnica e a partir da linguagem oferecida pelo cotidiano e pelo impessoal em que ele encontra-se imerso.

Nessa proposta de ensino, os cânones são relegados a um segundo plano por, teoricamente, não refletirem a visão de mundo dos próprios alunos. Todavia, que visão de mundo seria essa? Seria a visão dos padrões sociais valorizados naquele determinado momento e naquela determinada classe. Parte-se, evidentemente, de um conceito de interpretação de textos literários extremamente equivocado, como se os textos não adquirissem autonomia e presença a qualquer tempo e como se a fusão de horizontes do diálogo com a tradição não se operasse na leitura de um clássico da literatura.

Quando a escola pública de qualidade se consolidou, tentava abranger o maior número de pessoas, objetivando uma formação cidadã abrangendo todas as condições, sexo e idades, ou seja, aqueles que procuravam colocar sua inteligência a serviço da emancipação (MATOS, 2006). Os ideais humanistas de educação, que buscavam o aperfeiçoamento moral e político, para aumentar o bem-estar, aprimorar os sentidos por meio da educação estética, desenvolver a imaginação criadora e a fantasia com o estudo da literatura, das religiões, das artes e da filosofia, estão se perdendo (MATOS, 2006). E, mais do que isso, perde-se o interesse na verdadeira formação do homem, conforme aqui se propõe. Ocupam o espaço deixado vazio a mídia e a indústria cultural. Mesmo porque, nas palavras de Sartre (2006, p. 88), “a facilidade vende mais: é o talento subjugado, voltado contra si mesmo, a arte de tranqüilizar por meio de discursos harmoniosos e previsíveis, de mostrar, num tom educado, que o mundo e o homem são medíocres, transparentes, sem surpresas, sem ameaças e sem interesses".

O que importa ressaltar aqui é que essas diretrizes de ensino da literatura no Brasil são, na verdade, sintoma de um progressivo nivelamento do gosto, das relações e das identidades. Por vivermos em uma época da informação coletiva e rápida, a atividade solitária e lenta da leitura está sendo desprestigiada. Conforme Leyla Perrone-Moisés 
(2006b, p. 27), "respostas simples às grandes questões filosóficas e existenciais passaram a ser buscadas, por aqueles que ainda lêem, em manuais de auto-ajuda, mais reconfortantes do que os textos literários."

Defender quem você é, quando quem você é diverge das expectativas sociais dominantes, é considerado um desvio que o impessoal tentará suprimir. Os próprios homens podem acomodar-se, uma vez que o fardo da existência é bastante pesado. Conseguir prosseguir com este fardo requer uma coragem existencial. Essa é a coragem que possuem os escritores que produzem uma literatura autêntica. Ninguém é obrigado a escolher-se escritor, sendo que a própria origem do escritor está na liberdade: é-se escritor, em primeiro lugar, pelo livre projeto de escrever. E se assim é, melhor que esse projeto seja autêntico.

O conceito de gênio trazido por Kant é fundamental neste ponto. $\mathrm{O}$ gênio pode ser visto aqui como o artista que produz autenticamente, uma vez que sua criação não se vincula a uma base conceitual predeterminada, ultrapassando todo o conceito ${ }^{45}$. Não se trata, contudo, de adicionar adereços aos conceitos, mas verdadeiramente superá-los, admitindo-se que é a imaginação que irá conduzir ao entendimento. $O$ gênio surge do que Kant considerava imprescindível para o gosto estético: da ampliação do jogo vital que nasce da concordância entre imaginação e entendimento e que convida ao repouso ante o belo. $\mathrm{O}$ artista, e mais especificamente o escritor, sempre chega a algo que não se pode descobrir só pelo aprendizado e pelo trabalho metodológico ${ }^{46}$ (GADAMER, 2007a, pp. 95-97).

Assim, o escritor autêntico não prevê nem conjectura, mas sim projeta. Ele sabe que o futuro ainda não está feito e que é ele mesmo quem o fará, sendo que o futuro para ele é uma página em branco que depende de sua ação criativa para acontecer. Assim, para onde quer que ele se volte, o escritor só encontra o seu projeto, a sua imaginação, em suma, a si mesmo. Todavia, o escritor não projeta para si mesmo, mas sim, sempre, para o outro.

A literatura, bem como outras manifestações artísticas, é auto-representativa porque ela possui o modo de ser do jogo que se auto-representa. Dessa maneira, na representação é necessário que se dê uma modificação substancial do representado. A obra adquire, então, uma independência que estende seu efeito sobre a realidade representada. A literatura proporciona um crescimento de plasticidade à realidade e permite que o que é representado realmente se mostre (GADAMER, 2007a, pp. 202-204). Portanto, não pretendemos

\footnotetext{
${ }^{45}$ Os valores sociais, as ideologias e os sistemas de comunicação podem ser tidos como bases conceituais.

${ }^{46}$ Por isso o conceito de gênio só é aplicável ao artista e a ninguém mais, porque somente no caso do artista é que a obra, de acordo com seu próprio ser, continua vinculada ao espírito, tanto ao que cria quanto àquele que usufrui. São invenções que nesse sentido não podem ser imitadas.
} 
afirmar que a literatura social deva ser completamente desinteressada no sentido de não possuir qualquer relação, intencional ou não, com a realidade que representa, mas sim que se configura como um novo processo ontológico, enriquecendo o ser do representado, da sociedade à qual está relacionada, estando, portanto, primordialmente ligada a ele. O crescimento do ser operado pela criação literária, contudo, deve ser, esse sim, desinteressado.

Em algumas sociedades, principalmente as que se expressam por meio da literatura oral, a criação, a apreciação e a circulação das obras dependem imensamente do entrosamento geral dos fatos sociais. As obras, nesse sentido, não dispõem de muita autonomia, pois perdem o sentido à medida que se desligam do contexto; mesmo quando transcritas não são textos decifráveis diretamente. Tal literatura é elaborada para incorporar imediatamente a experiência do grupo e sua visão de mundo e da sociedade, em oposição à literatura escrita, cuja compreensão e o efeito emocional prescindem da participação da coletividade, do desempenho de um cantor e do conhecimento das circunstâncias que motivaram a obra (CANDIDO, 2006b, pp. 51-80).

Candido contrapõe os cantos fúnebres como o roia kurireu (canto grande), dos bororo, com a Nênia de Firmino da Silva, à morte de Francisco Bernardino Ribeiro e com o Adonai, escrito por Percy Bysshe Shelley (1792-1822), para lamentar a morte de John Keats (1795-1821). O roia kurireu possui a finalidade de celebrar experiências coletivas, mas tem lugar em uma dada situação, sendo recriado por cantores e bailarinos a cada execução. A Nênia e o Adonai constituem, por seu turno, um sistema expressional autônomo. Dessa forma coloca o autor: "há um cruzamento de significados, fazendo com que a composição poética, - motivada pela Morte, não pelo morto, - só funcione com relação a cada morto, e não à Morte. Inversamente, na poesia erudita, as nênias motivadas em geral por um determinado morto, acabam por funcionar, não em relação a ele, mas ao fenômeno impessoal da Morte" (CANDIDO, 2006b, p. 60).

Desse exemplo se conclui que algumas espécies de expressões literárias possuem vínculo com um dado contexto e uma menor independência e universalidade. Há, inclusive, quem diga que algumas dessas expressões não poderiam ser denominadas literatura, uma vez que para a sociedade que as concebe e reproduz possuem uma função social muito específica, sendo expressões ocasionais e particularistas.

Para M. P. Natali (2006), por exemplo, existe um preço a ser pago pela tentativa de incluir formas particularistas de expressão em um sistema que se imagina comportar a multiplicidade da experiência humana. O preço seria justamente abdicar da especificidade 
histórica e conceitual de práticas discursivas que passam a ser denominadas literatura. Segundo ele, as reflexões sobre a literatura são em geral universalistas e enfatizam sua falta de contornos e uma aparente a-historicidade (NATALI, 2006, p.32), sendo que a categoria literatura (e mais especificamente seu caráter ficcional) abarcaria todas as manifestações que não podem ser classificadas como representações discursivas objetivas. Todavia, Natali perde a oportunidade de enxergar a literatura não como fruto de um pensamento modernista universalizante e talvez uniformizante - que tolera o multiculturalismo apenas superficialmente para incorporá-lo em um sistema -; mas sim como uma forma de operar a fusão de horizontes e visões de mundo que não sacrifica as particularidades, mas sim permite que elas dialoguem e expressem uma verdade que vincula o escritor e os leitores. A literatura e sua autonomia somente são possíveis, portanto, por seu modo de ser tão histórico quanto o do homem.

Tentamos demonstrar neste ponto que a literatura não é um conceito que rouba as representações de sua função social e contextual, ou como uma categoria na qual encaixamos as obras, mas aproxima-se da denominação de um modo de ser peculiar de determinadas representações. Modo de ser este caracterizado também pela independência da obra com relação às condições de produção. A plurivalência, as diversas possibilidades que guardam a linguagem, a palavra e a composição nada mais são do que o trabalho artístico sobre a palavra, conferindo ao texto uma flexibilidade que lhe permite ajustar-se aos mais diversos contextos.

Em defesa de Candido (2006b, pp. 60-61) suas próprias palavras devem ser suficientes:

[U]ma tragédia grega, composta para ser encenada em dadas ocasiões e de certa maneira pode ser lida hoje e guarda, nesta leitura, impacto suficiente para fazer sentir a pujança de sua 'função total'. (...) Mas, se o estudioso de literatura erra ao tratar as suas formas orais como texto, ajustando-as ao nosso sistema simbólico, transpondo-as para nosso mundo de valores, o erro do folclorista é simétrico. Incapaz, como aquele, de jogar com um certo número de conceitos interpretativos, tende ao registro pura e simples, ou a comparações arbitrárias.(...) $\mathrm{O}$ ideal, como vimos, seria a união dos três pontos de vista [do etnólogo, do sociólogo e do folclorista], levando em conta o quadro sociocultural em que as manifestações literárias se situam, mas procurando captá-las na integridade de seu significado.

Essa proposta interpretativa diz muito a respeito da forma como a literatura relaciona-se com o contexto circunstancial e ao mesmo tempo adquire valência 
ontológica própria e livre, assim como o homem. Segundo Gadamer (2007a, p. 173), "trata-se de um todo significativo, que como tal pode ser interpretado e entendido em seu sentido repetidas vezes".

A gratuidade da literatura, portanto, aparece tanto no momento da criação (concepção e execução) quanto no momento de recepção (sentir e apreciar). Mesmo quando se trata de grupos humanos muito ligados às necessidades de sobrevivência, observa-se que a angústia e a euforia resultantes das atividades diárias para exploração do meio são moldadas em manifestações de caráter estético. Exemplares mais antigos da arte parecem ligados a práticas de magia imitativa, mostrando que o pragmático e o desinteressado, a necessidade de atuar e o desejo de fantasia estão ligados de forma muito estreita na vida dos grupos em diversos momentos.

A literatura não se trata de uma atividade utilitária, que se explicaria meramente pelo conhecimento de sua função social. Esse aspecto desinteressado, a gratuidade, além de ser parte essencial de seu modo de ser, ajuda a rebater teorias que desconsideram a autenticidade do artista e o elemento criador. $\mathrm{O}$ artista, portanto, torna-se um intérprete de todos, por meio do que ele tem de mais seu. Esse conceito é mais aprimorado ainda na literatura escrita, tendo em vista que o autor em geral parte de experiências próprias que acabam por se fazerem presentes nos contextos mais diversos, dos mais variados leitores em todos os tempos. A literatura, ainda nessa perspectiva, pode ser encarada como uma forma de realização da identidade do artista que se incorpora ao patrimônio comum, à tradição ${ }^{47}$. É somente essa a contribuição do escritor, sendo que ele sempre consome e não produz, mesmo que tenha decidido servir com seus escritos aos interesses da comunidade. Suas obras permanecem gratuitas, portanto, inestimáveis.

Mesmo quando se propõe a fornecer a expressão estética do que a elite pensa de si própria, mesmo quando se propõe a ser, em certa medida, um espelho dos valores dominantes, servindo a eles, se a obra for representativa, o espelho que apresenta modestamente a seus leitores é mágico: ele cativa ao mesmo tempo em que compromete. Mesmo que tudo seja feito para lhes oferecer uma imagem aduladora e cúmplice, essa imagem não deixa de ser uma obra de arte, ou seja, tem seu fundamento nas liberdades do escritor e do leitor (SARTRE, 2006, pp. 65-75).

Por fim, não podemos deixar de reconhecer a literatura como forma de atuação humana sobre o mundo e de equilíbrio coletivo e individual; a arte é elemento necessário

${ }^{47}$ Esse aspecto de perenidade, de presença da literatura será mais detalhadamente abordado no quarto capítulo que tratará da literatura no tempo. 
para a sobrevivência de uma sociedade. Ela atua nesse sentido à medida que traduz impulsos e necessidades de expressão, de comunicação e de integração, adquirindo sentido expressivo atuante, necessário à existência do grupo. Ela faz parte do complexo de relações e instituições que intitulamos sociedade. Percebemos que a literatura carrega dentro de si uma dicotomia não excludente, um jogo dialético entre a integração e a diferenciação. A integração seria o conjunto de fatores expressos na obra literária que tendem a acentuar, no indivíduo ou no grupo, a participação nos valores comuns da sociedade ${ }^{48}$, a diferenciação, ao contrário, seria o conjunto dos que tendem a acentuar as peculiaridades, as diferenças que existem em uns e outros ${ }^{49}$ (CANDIDO, 2006b, p. 33).

Apesar de a obra literária expressar, em maior ou menor medida, aspectos derivados de valores sociais e ideologias e possuir um papel social bem delineado em alguns contextos, o escritor deve ser livre para criar uma literatura autêntica que opere um crescimento no ser do mundo representado. Somente assim poderá exercer sua humanidade enquanto condição de liberdade frente ao mundo circundante.

\subsection{O PÚBLICO E A INTERPRETAÇÃO AUTÊNTICA}

O público, por seu turno, consiste em um elemento que pode vincular ou dar asas à literatura, dependendo, dentre outros fatores, como a autenticidade da própria obra, da autenticidade da sua interpretação. Enquanto que para o escritor o futuro é uma página em branco, para o leitor são inúmeras páginas sobrecarregadas de palavras que o separam do final (SARTRE, 2006, p. 36). Aliás, nada depende tanto do espírito imbuído de compreensão como a leitura. Nas palavras de Gadamer (2007a, p. 230):

Em seu deciframento [da escrita] e interpretação dá-se um verdadeiro milagre: a transformação de algo estranho e morto em um ser absolutamente familiar e coetâneo.

\footnotetext{
${ }^{48}$ Os elementos de integração de uma obra literária são inspirados principalmente na experiência coletiva e procuram incorporar-se a um sistema simbólico vigente, utilizando o que já está estabelecido como forma de expressão de determinada sociedade (CANDIDO, 2006b, p. 33).

49 Os elementos de diferenciação preocupam-se em renovar o sistema simbólico, criar novos recursos expressivos (CANDIDO, 2006b, p. 33).
} 
$\mathrm{Na}$ arte da literatura (escrita), o público tem uma característica bastante peculiar: ele é indeterminável ${ }^{50}$. Pode até ser que o autor tenha determinado público em mente quando escreve, todavia, em vista da perenidade e da fluidez da literatura, é impossível precisar em quais mãos a obra chegará. Nas palavras de Candido (2006b, p. 45):

\begin{abstract}
A invenção da escrita (para o caso da literatura) mudou esta situação [de grande proximidade do público com o artista], abrindo uma era em que foram tendendo a predominar os públicos indiretos, de contactos secundários, já referidos, e que adquiriram ímpeto vertiginoso com a invenção da tipografia e o fim do mecenato estamental.
\end{abstract}

Quando tratamos do público, percebemos outro tipo de influência de valores sociais na obra, mais especificamente em sua interpretação. Isso porque a moda, o gosto do público, sempre exprime expectativas sociais que por vezes são tirânicas ao que usufrui da arte. Às vezes o que consideramos uma reação espontânea de nosso juízo frente a uma obra literária nada mais é do que uma conformação aos padrões sociais. Assim como a criação, também a interpretação pode ser influenciada em maior ou menor medida pelo impessoal. Como tendemos a introjetar essas normas sociais, a nossa reação à obra nos parece perfeitamente sincera e nos dá satisfação das verdadeiras descobertas. Discutiremos no próximo capítulo mais do diálogo travado entre a obra e o público, bem como a respeito das influências deste sobre a obra.

Assim, continuando a reflexão acerca da absorção da literatura pela opinião pública (nivelamento) e a ameaça aos hábitos de leitura realmente autênticos, podemos mencionar que, hoje, setenta e cinco por cento (75\%) dos jovens têm algum som ligado enquanto lêem, como o rádio, por exemplo. Isso quando não se trata da televisão que captura a atenção visual que deveria ser dirigida à leitura naquele momento. Semileitores tornam-se também pseudoformadores no pensamento e na vida (MATOS, 2006).

Essa situação deveria, portanto, trazer uma reflexão acerca da leitura e do rompimento com a tradição, visto que as crianças e jovens estão hipnoticamente ligados a equipamento eletrônicos no momento crucial em que deveriam passar pela formação de sua identidade, de seu pensamento, das preferências intelectuais e da sensibilidade. Essa reflexão é integrada no raciocínio empenhado para que se perceba a ameaça à literatura

\footnotetext{
${ }^{50}$ Essa indeterminação pode ser maior ou menor a depender da complexidade da estrutura social. Em algumas comunidades, o pequeno número de componentes e o entrosamento das manifestações artísticas com os demais aspectos da vida social dão lugar a uma participação de todos na execução de um canto ou uma recitação, fazendo com que não seja distinguível o artista do público. Além disso, às vezes o público pode configurar-se em grupos limitados, contudo, seu estado normal é o de "massa abstrata" (CANDIDO, 2006b, pp. 44-45).
} 
autêntica e suas conseqüências, tendo em vista a importância dela para a formação das pessoas e para a preservação da memória da humanidade (MATOS, 2006).

Assim, como pode a literatura proporcionar aos leitores uma experiência autêntica, para além de suas expectativas e conceitos?

Em primeiro lugar, cabe uma breve explicação de como ocorre a transformação em configuração da arte, passando a obra a ser um ente autônomo, isto é, com um ser distinto do autor que a concebeu e que proporciona o a continuidade do leitor consigo mesmo de forma especulativa e dialética.

Sendo a literatura representação, todo representar é um representar para alguém, além do próprio artista, ou seja, o público (GADAMER, 2007a, p. 162). A representação da literatura encontra, na maior parte das vezes, na leitura sua realização. Pode-se dizer que a arte realiza-se enquanto o escritor ultrapassa a si próprio e representa uma totalidade de sentido para o público. Portanto, a obra literária e sua reprodução ${ }^{51}$ são representação. Assim, enquanto não ocorre o ato de leitura, o texto permanece o exílio do ser, enquanto não se faz linguagem (MAMAN, 2003, p. 114).

O fato é que o escritor não cria para si próprio, o ato criador é apenas um momento incompleto e abstrato da produção de uma obra. É, portanto, o esforço conjugado do autor e do leitor que fará surgir esse objeto concreto e imaginário que é a obra do espírito.

Gadamer entende que a consumação da arte se dá na transformação do jogo humano em configuração: nessa transformação, a arte libera-se da atividade representativa do escritor e constitui-se no puro fenômeno daquilo que a literatura representa. Assim: "[f]rente a todos eles [leitores e autor], o jogo possui uma autonomia absoluta, e é justamente o que deve assinalar o conceito de transformação [em configuração]”. (GADAMER, 2007a, p. 165). Portanto, a identidade do autor não continua existindo para ninguém, "os jogadores (ou poetas) não existem mais, existe apenas o que é jogado por eles" (GADAMER, 2007a, p. 167). Passa a haver, portanto, outro mundo que não se mede a partir de nada que esteja fora dele e não se admite mais nenhuma comparação com a realidade como se essa fosse um padrão a ser imitado figurativamente. Pelo menos, a imitação não é o que configura o modo de ser da literatura como arte. Conforme mencionado anteriormente, a literatura autêntica não é mera cópia dos valores sociais e ideologias.

\footnotetext{
${ }^{51}$ Que pode ocorrer tanto no ato silencioso e solitário da leitura, quanto na apresentação teatral, por exemplo.
} 
Evidentemente que isso não significa que a literatura seja alienada do mundo da existência. Muito pelo contrário: o mundo que vem à representação na literatura não se trata nunca de um mundo estranho, mas é sempre o seu próprio mundo, faz parte da tradição comum do escritor e do leitor ${ }^{52}$ (GADAMER, 2007a, pp. 192-193). Marisa Lajolo (2001) afirma que o mundo representado na literatura não é de todo simbólico, tendo em vista que nasce da experiência que o próprio escritor tem de sua realidade histórica e social. Assim, a criação literária nasce de uma imaginação ancorada à realidade e seu compromisso com um mundo possível não desvincula a literatura do presente como ponto de partida ou de chegada.

Desse modo, na leitura de um texto literário, autor e leitor compartilham um universo. Universo este construído a partir da criação do autor e recriação do leitor e único para cada autor e leitor específicos. Ocorre uma síntese no evento da leitura, mesmo que na maioria das vezes, senão em todas elas, os contextos da criação e da recriação para autor e leitor não coincidam. Isso porque a compreensão do texto literário, enquanto desvelamento que é, bem como a compreensão da vida e da existência, se dá a partir da fusão de um com o outro: escritor e leitor. A opinião de Harold Bloom (2001) sobre a leitura, que concorda com a interpretação de Lajolo, seria a seguinte: no ato da leitura se deveria buscar encontrar algo que nos dissesse respeito, que pudesse ser utilizado como base para avaliar, refletir, que parecesse ser fruto de uma natureza semelhante à nossa, que fosse livre da tirania do tempo. Em última análise, para Bloom, a leitura feita dessa forma proporcionaria um fortalecimento do ego, ajudaria na busca dos autênticos interesses do ego, tratando-se de um crescimento que, ao mesmo tempo, nos proporciona prazer.

Assim, fica claro que, a partir da transformação em configuração, o mundo que nos é apresentado na literatura concentra-se em um núcleo de sentido independente. Todavia, o mundo do qual o leitor é arrancado pela literatura é o próprio mundo que lhe é devolvido; porém, aqui ele pode participar verdadeiramente. Na medida em que se opera o autoesquecimento do leitor, ele reconhece a si próprio e os seus próprios valores sendo trazidos de uma forma dialética e especulativa. Dessa forma, ele recobra e aprofunda a continuidade consigo mesmo. Em outras palavras, o abandono do leitor frente à literatura e o seu envolvimento naquele novo mundo que se apresenta proporcionam uma experiência verdadeira de contato profundo com seus valores, de forma a possibilitar a emergência da questão da identidade.

52 A representação na literatura possui uma continuidade de sentido tanto com o mundo (horizonte) do escritor quanto com o mundo (horizonte) do leitor. 
Como toda leitura compreensiva é uma forma de reprodução e interpretação, a implicação da autonomia adquirida pela obra ${ }^{53}$, na leitura e interpretação desta, é que o texto deve ser compreendido em sua idealidade plena, ou seja, o sentido a ser apreendido deve ser desvinculado do escritor. Em suas variadas representações (na leitura), a obra desdobra-se em suas diversas possibilidades de ser. Somente assim é possível ao leitor que compreende defender sua própria pretensão de verdade no que veremos ser o exercício (a aventura) cognitivo autêntico da leitura. A literatura, portanto, possui a espontaneidade do entendimento e do jogo em sua representação para expressar as questões de forma dialética.

A partir do próximo tópico, veremos com maior profundidade como a literatura representa o mundo e os dilemas éticos do homem, contribuindo para a constituição de sua identidade.

\subsection{O EXEMPlo DA FACUldade DE Direito}

Com intuito de explicar melhor como funcionam as interações entre meio social, artista e público, partiremos de um exemplo utilizado também por Candido (2006b, pp. 154-165): o exemplo da Faculdade de Direito do Largo de São Francisco. Esse exemplo parece muito adequado, inclusive, porque a presente dissertação está sendo desenvolvida nessa mesma academia. Evidentemente que não exploraremos todos os autores que floresceram nesta casa, sequer todos os aspectos literários de suas obras, mas somente na medida em que contribuem para a explicitação de alguns pontos importantes da mencionada interação.

Vale ressaltar que partiremos do momento de criação da faculdade para dizer que naquela época tratava-se menos de uma escola de juristas do que de um ambiente propício ao encontro e desenvolvimento dos que se interessavam pelas coisas do espírito e da vida pública. A convivência acadêmica e o espírito de grupo dela decorrente manifestaram-se na esfera literária de forma muito significativa, dando abertura para expressões originais (CANDIDO, 2006b, pp. 154-165).

\footnotetext{
${ }^{53}$ Desde o momento de sua criação.
} 
A partir de uma etapa preliminar em que os estudantes se articulam e adquirem consciência de seu estado enquanto grupo, eles passam a se destacar da população da pequena cidade de São Paulo de outrora. A partir da década de 1840, o grupo passa a consolidar uma expressão própria. Uma cidade tão pequena e provinciana era regida por padrões sociais muito específicos em todos os papéis que seus cidadãos desempenhavam. Assim, a tendência uniformizadora que atraía aquela população para a opinião pública era muito forte. Contudo, veremos que mesmo assim São Paulo foi o cenário para o impulso de liberdade frente ao mundo circundante dos estudantes da Faculdade de Direito (CANDIDO, 2006b, pp. 154-165).

Sobre a força planificadora do impessoal, disserta Candido (2006b, p. 157):

[Os padrões sociais previam o comportamento] daquilo que os rapazes seriam depois do curso, depois de casados, compadres, pais de família, liberais ou conservadores, almoçando às oito, jantando às três, ceando às sete, dormindo às nove. Mas que padrões se ajustariam ao comportamento de dezenas e logo centenas de moços de gravata lavada, ocupados em atividades tão fora do esquadro [a literatura]?

Mas agora olhemos para o perfil desses estudantes: eram jovens, localizados na passagem da adolescência à maturidade que antes foram meninos de família e depois desempenhariam papéis sociais de elite, porém ordinários e adequados à sua classe políticos, intelectuais, proprietários. Todavia, naquele momento esses jovens apresentaram padrões excepcionais de comportamento e arrisca-se afirmar que é pouco provável que tenham passado incólumes por estas experiências literárias: a definição de sua identidade, para além do papel social que viriam a desempenhar, já seria conduzida no flanco de uma compreensão do mundo e de seu ser diferenciada. A literatura, nesse caso, contribuiu tanto para a consolidação quanto para a expressão de sua alteridade. Ela representava propriamente o seu ethos peculiar. Além disso, suas obras literárias passaram a fazer parte da história, integrando-se como tradição ao tempo ${ }^{54}$.

O grupo estudantil que se reunia nas repúblicas e nas agremiações literárias constituía um meio estimulante para a produção literária, seja criando uma atmosfera de exceção, alheia às pressões familiares e sociais, seja integrando os estudantes uns aos outros em um grupo cujo modo de viver passava pela expressão literária. Assim, a partir do intercâmbio das criações ${ }^{55}$, os próprios estudantes constituíam o público de seus colegas,

\footnotetext{
${ }^{54}$ Como veremos no quarto capítulo.

${ }^{55}$ Seja por escrito, seja nos recitativos, discursos e tertúlias.
} 
garantindo a continuidade de sua literatura. É um bom exemplo de como o meio social pode influir na produção literária sem, contudo, regulá-la a ponto de roubar-lhe a espontaneidade e identidade próprias (CANDIDO, 2006b, pp. 154-165).

Além do cenário austero e sombrio que a cidade de São Paulo e a Faculdade de Direito deviam proporcionar, incitando a imaginação dos jovens, o romantismo serviu de ideologia para a constituição autônoma desse agrupamento acadêmico. Na Faculdade de Direito manifestou-se por três vias: o nacionalismo indianista, o sentimentalismo ultraromântico e o satanismo. Cumpre ressaltar que esses três ramos temáticos, estruturais e estilísticos influíram mais ou menos no grau de autenticidade das obras. Sendo que o nacionalismo indianista era o mais afetado por elementos particularistas do contexto de criação e o satanismo o mais independente, possibilitando um enriquecimento maior do representado pela representação (CANDIDO, 2006b, pp. 154-165).

Mesmo o nacionalismo indianista, consolidado por Gonçalves Dias (1823-1864) ${ }^{56}$, presente em todo o Brasil, adquiriu aspectos característicos a partir dos estímulos daquela atmosfera acadêmica. José de Alencar (1829-1877), que foi estudante do Largo São Francisco entre 1846 e 1850, foi um dos expoentes nesse gênero, com romances como $O$ guarani (1857), Iracema (1865) e Ubirajara $(1874)^{57}$. No caso de Alencar, o período estudantil serviu mais como uma etapa preparatória em que ele tomou contato com autores clássicos e passou a conceber uma literatura que fosse "um poema da vida real". Os romances indianistas, no entanto, só viriam a ser escritos mais tarde. Nessa temática, o autor inaugurou a aparição da figura do herói em nosso romantismo, que não fora engendrada pela epopéia neoclássica, sequer pelo próprio Gonçalves Dias (CANDIDO, 2006b, pp. 154-165).

O sentimentalismo ultra-romântico também foi importante para a definição desse grupo de escritores, sendo que seu lirismo era repleto da solidão, incompreensão e infelicidade de que sofriam os estudantes, separados por um abismo da comunidade e dos homens comuns, ou melhor, da opinião pública; confirmando sua diferença e sua posição autárquica (CANDIDO, 2006b, p. 163). Assim, vejamos uma pequena amostra da enunciação poética de Álvares de Azevedo (1831-1852) (1942) a descrever esse abismo e solidão:

\footnotetext{
${ }^{56}$ E precedido pela obra Caramuru, de Santa Rita Durão.

${ }^{57}$ Dentro da temática nacionalista, ele escreveu também o romance $O$ sertanejo (1875), porém, apesar de esse livro ter contribuído para a formação do imaginário sertanejo na literatura brasileira, evidentemente que não integra a trilogia indianista.
} 
De meu pai... de meus únicos amigos, Pouco - bem poucos - e que não zombavam Quando, em noites de febre endoudecido, Minhas pálidas crenças duvidavam.

Só tu à mocidade sonhadora Do pálido poeta deste flores... Se viveu, foi por ti! e de esperança De na vida gozar de teus amores.

Descansem o meu leito solitário $\mathrm{Na}$ floresta dos homens esquecida, À sombra de uma cruz, e escrevam nela:

Foi poeta - sonhou - e amou na vida.

$\mathrm{Na}$ poesia pantagruélica (bestialógico pantagruélico), foram criados modos de expressão e normas próprias dos estudantes, sendo difícil e arbitrária a determinação da tradição que teria contribuído para essa criação. Bernardo Guimarães foi um dos maiores expoentes do bestialógico pantagruélico. No anfiguri, a relação com o mundo circundante é absolutamente intangível e a concordância semântica propositadamente ininteligível. Através desses textos, a representação singular em face da sociedade provinciana atingiu sua idealidade. Não cabe, portanto, ao leitor do anfiguri procurar nele "sentidos coerentes"; deve antes aceitar as regras do jogo e sua insanidade para poder apreciar a força poética das inesperadas associações de palavras (CANDIDO, 1993, pp. 237-239).

Assim, o bestialógico pantagruélico é um exemplo claro da literatura enquanto jogo de que trata Gadamer. Tanto o escritor quanto o seu público precisam entrar no jogo para que o entendimento seja possível, sendo que as regras lhe são próprias e, muitas vezes, bastante distantes da praticidade e objetividade da realidade. Mais adiante veremos como por meio da brincadeira (mais ou menos insólita) da linguagem podem definir-se elementos da identidade e personalidade do escritor e de seus leitores.

Destacou-se como agrupamento de estudantes do Largo São de Francisco a Sociedade Epicuréia, que constituía um "ponto de encontro entre a literatura e a vida onde os jovens procuraram dar realidade às suas imaginações românticas" (CANDIDO, 2006b, p. 160). Essa sociedade, criada em 1845 por Aureliano Lessa, Bernardo Guimarães e Álvares de Azevedo, contribuiu não só para a formação de jovens individualmente autênticos, mas também para a formação de um sentimento de grupo próprio de sua 
identidade. O satanismo e o byronismo foram expressões dos jovens que integravam a Sociedade, sendo que muitos boatos existem sobre eventos envolvendo seus membros, porém, é difícil determinar até onde eles são verídicos. Sintomaticamente, os únicos vestígios que nos alcançam, integrando nossa tradição, são frutos da produção literária.

A partir da década de 1870, no entanto, com o crescimento da cidade de São Paulo e o aumento da diversidade das atividades nela desempenhadas, o grupo de estudantes foi sendo incorporado à comunidade e incorporando-se às parcas possibilidades oferecidas por esta, "dissolvendo-se na vida comum” (CANDIDO, 2006b, p. 158). Essa perda da exceção foi, na realidade, fruto da expansão e predominância de uma situação que sempre existiu em paralelo: a dos estudantes que viviam alheios à efervescência acadêmica - decorando compêndios, almejando bons cargos e, nas palavras de Candido (2006b, p. 158), "antecipando-se à vida". 


\section{A LiTERATURA NA RELAÇÃO DO HOMEM COMO O MUNDO: CONSTRUÇÃO DE UMA} VISÃO DE MUNDO E DE SI PRÓPRIO

Candido observou, em 1988, que em comparação com outros momentos da história humana atingimos um nível máximo de racionalidade técnica e de domínio sobre a natureza, o que poderia permitir a resolução de um grande número de problemas materiais do homem. Contudo, a irracionalidade no comportamento humano e na dominação do outro e da natureza também atingiu seu auge, servida pelos mesmos meios que deveriam realizar os desígnios dessa racionalidade. Tudo isso só pode ser fruto de uma imensa insensibilidade que nega uma das linhas que, segundo o autor, é uma das mais promissoras da história do homem ocidental: "aquela que se nutriu das idéias amadurecidas no correr dos séculos XVIII e XIX, gerando o liberalismo e tendo no socialismo a sua manifestação mais coerente" (CANDIDO, 2004, pp. 169-170).

Todavia, conforme visto no primeiro capítulo, alguns desses pensamentos tomaram caminhos cujo destino eram as mais desenvolvidas formas de dominação. Na realidade, os conceitos de indivíduo e de sujeito, que pressupõem uma divisão do mundo em sujeitos e objetos, sendo que aqueles objetivam estes, podendo conhecê-los e, por conseqüência, dominá-los, sempre carregou esse risco latente.

\subsection{LiteratURA E HUMANIDADE}

A literatura desenvolve em nós a quota de humanidade na medida em que nos torna mais compreensivos e abertos para a natureza, a sociedade, o semelhante (CANDIDO, 2004, p. 180).

A partir do lirismo do teórico literário, que em muitos momentos extrapola a teoria e tangencia a própria literatura, devemos nos perguntar o que repousa sob esta afirmação. Em primeiro lugar, em que medida a literatura aprimora a compreensão humana? Em segundo lugar, o que significa "estar aberto"? Esses significados serão explorados na medida em que tratarmos dessas questões específicas, contudo, é evidente que esse aprimoramento descrito por Candido é fundamental para a humanização. 
Começaremos por fazer uma reflexão introdutória da forma como a literatura contribui para a formação da personalidade e da identidade das pessoas que com ela entram em contato, seja como escritor, seja como leitor. Essa formação da personalidade e da identidade não acontece, aqui, com base nas convenções, mas antes segundo força poderosa e indiscriminada da própria realidade (CANDIDO, 2004, pp.175-176). Assim, compreender e estar aberto significa cultivar uma relação peculiar com o mundo, que possibilita que enxerguemos os caminhos que ele oferece; alguns ocultos ou ainda não desbravados, sequer inventados. Desse modo é necessário que se esteja atento para o extraordinário $^{58}$ que brilha em cada coisa ordinária. A emergência e o encobrimento que moram em todos os entes são o que a experiência necessita admirar: "o admirável é, para os gregos, o simples, o sutil, o próprio ser" (HEIDEGGER, 2008c, p. 148). O ser é o que em todos os entes se mostra a si mesmo e o que a partir dele brilha através deles.

Neste ponto, portanto, é possível ver um dos aspectos pelos quais a palavra possui uma vinculação com o ser: na medida em que o homem entra em contato com o extraordinário e com as possibilidades a partir da linguagem. Isso é a linguagem, esse colocar diante de nós o possível, a idéia do porvir, graças à qual nos encontramos no caminho, desejosos e seletivos (GADAMER, 1993, p. 152).

A realidade, na literatura, sofre uma transfiguração mediada pela imaginação, transformação essa importantíssima para nossa capacidade de inventarmos a nós mesmos, sendo capazes não só de compreendermos a realidade, mas também de estarmos abertos às suas possibilidades de sentido. Assim, não há homem ou povo que possa viver sem o contato com alguma espécie de fabulação (CANDIDO, 2004, p.174). Nas palavras de Jose Ortega y Gasset (1961, p. 203, apud BLATTNER, 2006, pp. 36-37):

Quase sempre se esquece que o homem é impossível sem imaginação, sem a capacidade de inventar para si próprio uma concepção da vida, de idealizar o personagem que ele será (tradução livre da autora).

Desse modo, o empoderamento depende do viver imaginativamente, flexivelmente, mais do que rigorosamente. Isso significa não fazer só o que é apropriado, convencional ao contexto social, mas responder criativa e flexivelmente às situações. Isso porque todo presente finito tem seus limites, o que significa que sempre estamos inseridos em uma situação existencial que limita nossas possibilidades de ver. Contudo, podemos ter uma

${ }^{58} \mathrm{O}$ extra-ordinário é o simples, o sutil, o inacessível para as garras da vontade, o que se subtrai a todos os artifícios do cálculo. 
abertura mais estreita ou ampla com relação ao mundo, o que chamaremos de horizonte. Dependendo da amplitude de nosso horizonte, conseguimos ver além do que está mais próximo e dimensionar adequadamente os elementos de nosso campo de visão.

A abertura do horizonte e, por conseguinte, a visão de nossas possibilidades, está integrada fundamentalmente ao conhecimento que temos de nós próprios, pois dela depende a definição de nosso papel no mundo. Quando nos falta imaginação, possuímos um entendimento superficial do mundo ${ }^{59}$ e de nós mesmos, nos falta imaginação existencial. O nosso pertencimento ao mundo e nossa ética mais originária, contudo, só são determinados à medida que vivemos, e a literatura é uma espécie de vida.

A criação ficcional ou poética está sempre presente em nossas vidas, manifestandose nos sonhos e, durante a vigília, em nossos devaneios imaginativos, na leitura de romances, nas brincadeiras e jogos, nas canções, no carnaval - em seus ritmos e fantasias e na literatura encontra o seu modo mais aperfeiçoado e completo. Não é à toa que Candido refere-se à literatura como "o sonho acordado das civilizações" (CANDIDO, 2004, pp.174-175).

Aqui, percebe-se que a literatura e a fantasia conseguem realizar o resgate de nosso contato com as estruturas inconscientes nas quais o prazer repousa adormecido, sendo que o espaço reservado para elas em nossa vida cotidiana está cada vez mais restrito a "momentos de lazer" pré-determinados por nosso contexto produtivo. A literatura consegue estabelecer o vínculo de nossa consciência com essa instância de nossa mente que é reputada como desordenada e impulsiva, porque, embora tenha a criação ficcional e imaginativa como mola de sua produção, a literatura mantém sempre referência ao mundo que representa, bem como está vinculada, em função da hermenêutica, ao mundo em que é reproduzida. Além disso, a força da literatura constitui-se em sua capacidade de criar formas pertinentes aos conteúdos e temas que trata. Essas formas estilísticas trazem beleza aos textos literários, ao mesmo tempo em que cuidadosamente lhes conferem uma ordem.

Conforme se destacou anteriormente, a temática social não é critério suficiente para estimar a força humanizadora de uma obra; é necessário que o texto tenha certa qualidade representativa e formal. Candido cita o exemplo de duas obras que tratam da mesma temática: A escrava Isaura, de Bernardo Guimarães e Navio negreiro de Castro Alves. Segundo ele, a representação de Castro Alves possui uma força muito maior, porque, ao

\footnotetext{
${ }^{59}$ Quando entendemos algumas coisas superficialmente, não sabemos explorar suas possibilidades.
} 
retratar um contexto social, e estando Castro Alves vinculado a uma determinada situação existencial, é muito mais transcendente, por conta da qualidade de sua elaboração estilística.

Assim, o esvaziamento da linguagem e a decomposição das formas literárias provêm de uma ameaça à essência existencial do homem. A partir do domínio da subjetividade, a linguagem é afastada do ser e abandona-se ao nosso puro querer e à nossa atividade, como um instrumento de dominação sobre o ente (HEIDEGGER, 2005, pp. 1416). Isso torna o auto-aperfeiçoamento a partir da literatura, juntamente com a reconstrução da própria linguagem, um projeto grandioso. Além disso, ao nos tornarmos leitores autênticos os resultados dos nossos esforços nos afirmarão como portadores de luz a outras pessoas. O papel da literatura, nesse sentido, se daria no âmbito espiritual, humano, psicológico, educacional de cada indivíduo (BLOOM, 2001).

A partir daí, tem-se que a literatura não é uma experiência inofensiva, mas uma aventura que pode ter impactos psíquicos e morais, como acontece com a própria vida, da qual é imagem e transfiguração (CANDIDO, 2004, pp.175-176). A literatura pode até mesmo nos trazer a angústia que nos leva à tomada de consciência de nossa condição existencial, o que significa que ao revelar ao homem as possibilidades, ela revela também o peso da escolha de sua identidade no encontro consigo mesmo. Em uma crônica de ano novo, Clarice Lispector (1999, pp. 160-161) discorria acerca do pensamento de H. D. Thoureau; ela escreveu:

Thoureau achava que o medo era a causa da ruína dos nossos momentos presentes. E também as assustadoras opiniões que nós temos de nós mesmos. Dizia ele: "A opinião pública é uma tirana débil, se comparada à opinião que temos de nós mesmos." É verdade: mesmo as pessoas cheias de segurança aparente julgam-se tão mal que no fundo estão alarmadas. E isso, na opinião de Thoureau, é grave, pois "o que o homem pensa a respeito de si mesmo determina, ou melhor, revela seu destino".

O que não é necessariamente o caminho mais cômodo, como por exemplo, o deixarse levar pela correnteza da impessoalidade, mas certamente é o caminho mais humano. 


\subsection{Visão de Mundo E Horizonte}

Como quisemos demonstrar, o mundo é o horizonte da compreensão e um espaço de possibilidades em cujo cenário entendemos nós mesmos. A relação humana com o mundo tem o caráter de linguagem de modo absoluto, sendo, portanto, compreensível de modo absoluto. E, nesse sentido, a linguagem é central para o nosso ser no mundo: para nossa consciência e intencionalidade. A linguagem não é só um dos dons humanos, mas mais do que isso, dela depende o fato de o homem ter um mundo (GADAMER, 2007a, p. 571).

A arte imita o jogo infinito do mundo, sendo que ela continuamente representa e cria o mundo para o homem. Cada palavra de uma obra literária deixa transparecer o conjunto da concepção de mundo que lhe subjaz.

Algumas poesias, por exemplo, elaboradas em um contexto em que a relação do homem com o mundo é determinada pela busca pela sobrevivência, têm como função a organização dessa relação no plano da ilusão, para que esta realidade, que é a realidade do seu mundo, possa ser "inteligível ao espírito". Outras poesias utilizam-se da alusão aos elementos relacionados à sobrevivência fisiológica num plano absolutamente acessório, ou como elemento descritivo (recurso de composição), ou como forma de trazer seu significado simbólico. O plano estético e simbólico é muito mais desenvolvido nessas obras porque assim o permite a visão de mundo subjacente. É estabelecida pela linguagem, portanto, uma mediação significativa entre o plano meramente fisiológico e a expressão artística.

Um dos aspectos do modo de ser da literatura seria a maneira pela qual a obra é construída, aspecto esse fundamental para a constituição de determinada expressão como literatura. $\mathrm{O}$ poeta ou escritor, à medida que elaboram uma estrutura, escolhe e organiza as palavras de modo a surgir um modelo de coerência. Esse modo de ser de coisa organizada da obra literária contribui para que o artista, em um primeiro momento, e o leitor em um segundo momento, ordenem suas próprias mentes e sentimentos, e, por conseguinte, sejam capazes de estruturar sua visão do mundo (CANDIDO, 2004, p. 177). Nas palavras de Candido (2006b, p. 63):

(...) a arte, e portanto a literatura, é uma transposição do real para o ilusório por meio de uma estilização formal, que propõe um tipo arbitrário de ordem para as coisas, os seres, os sentimentos. Nela se combinam um elemento de vinculação à realidade natural ou social, e um elemento de manipulação técnica, indispensável à sua configuração, e implicando uma atitude de gratuidade. 
Assim, o escritor, quando escolhe qual a melhor forma para a sua mensagem, está escolhendo uma dentre as inúmeras possibilidades que a linguagem lhe proporciona, sendo que essa escolha estabelece sua visão de mundo. Assim, não só a literatura possibilita que consigamos ver as possibilidades que o mundo nos reserva ${ }^{60}$, mas também propicia uma diversidade de possibilidades de sentidos do mundo. Segundo Sartre, isso se denomina modificação estética do projeto humano (2006, pp. 48-49):

(...) sentimento de segurança; é ele que impregna de uma calma soberana as emoções estéticas mais fortes, e tem por origem a verificação de uma harmonia rigorosa entre subjetividade e objetividade. Como, de outro lado, o objeto estético é propriamente o mundo, na medida em que é visado através dos imaginários, a alegria estética acompanha a consciência posicional de que o mundo é um valor, isto é, uma tarefa proposta à liberdade humana. A isso chamarei de modificação estética do projeto humano, pois de ordinário o mundo aparece como horizonte da nossa situação, como a distância infinita que nos separa de nós mesmos (sem grifos no original).

Em qualquer linguagem que exploremos as possibilidades, alcançaremos um aspecto cada vez mais amplo, uma visão do mundo. Todavia, vale destacar que essas visões de mundo não são relativas, no sentido de que se lhes oporia um mundo em si. Em cada visão já há o mundo, assim como todas as visões de mundo são próprias, nossas. Só poderia haver uma visão de um mundo em si se encontrássemos o Aleph descrito por Jorge Luiz Borges (2001), todavia, mesmo a descrição do que o escritor viu no Aleph demonstra que aquela visão do que seria o mundo em si na realidade era sua própria visão, que, no entanto, continha o mundo todo:

O diâmetro do Aleph seria de dois ou três centímetros, mas o espaço cósmico estava aí, sem diminuição de tamanho. Cada coisa (o cristal do espelho, digamos) era infinitas coisas, porque eu via claramente de todos os pontos do universo. Vi o populoso mar, vi a aurora e a tarde, vi as multidões da América, vi uma prateada teia de aranha no centro de uma negra pirâmide, vi um labirinto roto (era Londres), vi intermináveis olhos próximos perscrutando-me como num espelho, vi todos os espelhos do planeta e nenhum me refletiu, vi num pátio da rua Soler as mesmas lajotas que, há trinta anos, vi no vestíbulo de uma casa em Fray Bentos, vi cachos de uva, neve, tabaco, veios de metal, vapor de água, vi convexos desertos equatoriais e cada um de seus grãos de areia, vi em Inverness uma mulher que não esquecerei, via a violenta cabeleira, o altivo corpo, vi um câncer no peito, vi um círculo de terra seca numa calçada onde antes existira uma

\footnotetext{
${ }^{60}$ Em toda visão de mundo está o espaço aberto do futuro, que ocupa o livre espaço ao nosso redor. Contudo, estamos sempre a tropeçar nas esquinas da morte, que penetra nesse espaço e é seu próprio limite. A preocupação com nosso caminho, vislumbrar ao mesmo tempo o espaço aberto, planejar com antecedência, ocupar a linguagem com a fala e tropeçar sempre com a esquina final, que é a morte. Esses são os aspectos da finitude humana (GADAMER, 1993, p. 152).
} 
árvore, vi uma chácara de Adrogué, um exemplar da primeira versão inglesa de Plínio, a de Philemon Holland, vi, ao mesmo tempo, cada letra de cada página (em pequeno, eu costumava maravilhar-me com o fato de que as letras de um livro fechado não se misturassem e se perdessem no decorrer da noite), vi a noite e o dia contemporâneo, vi um poente em Quertétaro que parecia refletir a cor de uma rosa em Bengala, vi meu dormitório sem ninguém, vi num gabinete de Alkmaar um globo terrestre entre dois espelhos que o multiplicam indefinidamente, vi cavalos de crinas redemoinhadas numa praia no mar Cáspio, na aurora, vi a delicada ossatura de uma mão, vi os sobreviventes de uma batalha enviando cartões-postais, vi numa vitrina de Mirzarpur um baralho espanhol, vi as sombras oblíquas de algumas samambaias no chão de uma estufa, vi tigres, êmbolos, bisões, marulhos e exércitos, vi todas as formigas que existem na terra, vi um astrolábio persa, vi numa gaveta da escrivaninha (e a letra me fez tremer) cartas obscenas, inacreditáveis, precisas, que Beatriz dirigia a Carlos Argentino, vi um adorado monumento em La Chacarita, via relíquia atroz do que deliciosamente fora Beatriz Viterbo, vi a circulação de meu escuro sangue, vi a engrenagem do amor e a modificação da morte, vi o Aleph, de todos os pontos, vi no Aleph a terra, e na terra outra vez o Aleph, e no Aleph a terra, vi meu rosto e minhas vísceras, vi teu rosto e senti vertigem e chorei, porque meus olhos haviam visto esse objeto secreto e conjetural cujo nome usurpam os homens, mas que nenhum homem olhou: o inconcebível universo (BORGES, 2001, pp. 170-171).

Não há nenhuma abordagem do mundo que o homem possa fazer que consiga abranger todas as visões, como se houvesse um mundo verdadeiro (GADAMER, 2007a, p. 577). No âmbito das ciências, e mais especialmente da física, pode parecer muitas vezes que o cientista tem por objeto o mundo em si e que obteve êxito em suplantar toda relatividade da existência ${ }^{61}$.

Em contrapartida, o comportamento do homem para com o mundo é muito diferente quando se têm em mente as realizações da linguagem. Existe uma diferença fundamental entre a objetividade da linguagem e das ciências: enquanto a ciência domina a experiência a ponto de torná-la disponível para seus fins arbitrários, a linguagem ajuda a compreendermos melhor certa experiência para que possamos colocá-la em perspectiva, adequá-la às devidas proporções (GADAMER, 2007a, pp. 584-585). Evidentemente que a relação que a ciência estabelece com o mundo também é calcada em uma visão de mundo e na linguagem. Contudo, as ciências optam por trabalhar com uma linguagem, na maioria das vezes, não discursiva, mas baseada em códigos e conceitos, o que determina sua visão

\footnotetext{
${ }^{61}$ As ciências jamais podem ter como objeto o ente em sua totalidade e pretender intitularem-se ciências universais. Isso porque não só investigam apenas o ente e não o ser dos entes, mas também possuem uma relatividade da existência que lhes é própria. As ciências conhecem o que é, e isso significa que o conhece tal como está dado no espaço e no tempo e como é objeto da experiência. Tanto a física como a biologia, por exemplo, projetaram previamente a região de seus objetos, e o conhecimento dessa região significa seu domínio (HEIDEGGER, 2008b).
} 
de mundo e, por conseguinte, seu comportamento em relação so mundo. Assim, na medida em que a opinião pública determina o que é ou não é compreensível, está também determinando a visão de mundo com a qual devemos ter contato.

Contudo, essa separação não é estanque. O físico Werner Heisenberg, por exemplo, responsável por descobertas fundamentais da mecânica quântica, como o princípio da incerteza, escreveu diversos livros em que relacionava a física com temas filosóficos ou com temas pouco cotidianos para muitos, mas que definiram não somente suas descobertas, mas momentos importantes de sua vida e de seus pensamentos. Ele descreve conversas longuíssimas que teve com seus colegas e outros físicos importantes, conversas tão longas quanto suas caminhadas. Esses livros demonstram que sua visão de mundo extrapolava os códigos matemáticos, e que ele não tinha a pretensão de objetivar um mundo em si. Curiosamente, um de seus livros é intitulado A parte e o todo, aludindo a seu entendimento de que nas visões parciais do mundo se revela o todo.

As palavras organizadas de um texto literário são mais do que a presença de um código: elas comunicam sempre alguma coisa que nos toca porque obedece a certa ordem. Quando recebemos o impacto de uma produção literária, oral ou escrita, ele é devido à fusão inextricável da mensagem com sua organização. O conteúdo só pode atuar na medida em que tem determinada forma, e a forma opera uma organização mental. Toda obra literária pressupõe algum nível de superação do caos, determinado por um arranjo especial das palavras e fazendo uma proposta de sentido (CANDIDO, 2004, p. 178).

Nesse sentido, a literatura dissolve a barreira entre instâncias caóticas da imaginação e a realidade que seria regida por princípios de organização. $O$ trabalho da forma não é alienante com relação ao mundo real, mas sim assinala outro modo de buscar a verdade: somente a forma dá aquela visão aguçada que abre caminhos através do emaranhado das coisas. Ao selecionar, o escritor atribui valores e sugere uma reordenação do mundo, onde a verdade se dá a ver (PERRONE-MOISÉS, L., 2006a, p. 106).

A própria palavra "texto" remete à materialidade do escrito, atenuando o intangível da palavra "criação". Forma-se, assim uma confluência entre o divino da gênese e o humano do objeto criado. O texto literário com sua forma organizada, portanto, é o fruto miraculoso desse encontro e pretende dar uma visão aguçada ao real, abrindo trilhas e desvendando verdades que não se vêem a olho nu; reordenando o mundo, selecionando, ritmando e fazendo sentido (PERRONE-MOISÉS, L., 2006a, pp. 100-107). 
A partir do momento que conseguimos realizar essa organização e formular uma proposta de sentido para o mundo a nossa volta, estaremos familiarizados com ele de uma forma muito especial; que significa apreender a significação, os significados das coisas que nele estão para nós. Quando fixamos determinados aspectos dos campos ou do mar, ou de nossos sentimentos na forma escrita, introduzindo ordem onde não havia nenhuma, impondo a unidade de espírito à diversidade dos entes, temos a consciência de produzi-los e sentimo-nos essenciais em relação ao mundo (SARTRE, 2006, p. 34).

Os sentimentos e evocações amorosas, por exemplo, são bastante vagos e pouco tangíveis. Exprimindo-os por meio da literatura, o poeta transforma o inexpresso em estrutura organizada. Além disso, essa construção lingüística implica um trabalho de tentar fazer o leitor sentir e pensar o que está representado, o que contribui também para a autonomia da obra. A autonomia dá chance de a obra transcender a emoção do autor: ela pode interpelar um leitor qualquer e servir para que ele possa representar mentalmente as situações amorosas desse tipo em tempos e lugares indeterminados. Os sentimentos passam de um estado de mera emoção para o da forma construída, que assegura a generalidade e a permanência (CANDIDO, 2004, p. 179).

Conforme vimos, o conteúdo atuante graças à forma constitui um par indissolúvel que redunda em certa modalidade de conhecimento. Este pode ser uma aquisição consciente de noções, emoções, sugestões ou se processar nas camadas do subconsciente, incorporandose em profundidade; essa incorporação enriquece a nossa percepção e nossa visão de mundo (CANDIDO, 2004, p. 179). A forma, nesse caso, permite que o conteúdo ganhe maior significado e ambos juntos aumentem nossa capacidade de ver e sentir o mundo.

Concluímos que o rigor do pensar não consiste na exatidão artificial, isto é, técnicoteórica dos conceitos ${ }^{62}$. O rigor repousa no fato de o dizer permanecer de modo puro no elemento do ser, deixando imperar o simples das múltiplas dimensões. Todavia, isso não significa que essas múltiplas dimensões das formulações lingüísticas não possam ser exercidas de forma cuidadosa e salutar, o que é oferecido pela forma escrita e sua organização (HEIDEGGER, 2005, p. 11). Só é preciso que o escritor tenha a cautela de a

\footnotetext{
${ }^{62} \mathrm{O}$ domínio da linguagem sobre o pensamento é tão intenso, que parte da filosofia grega dedicou seu empenho em libertar-se dele. O ser próprio da linguagem era pensado como um extravio que precisava ser banido e dominado pelo pensamento, sendo que o logos seria determinado pelo eidos. Essa abordagem desemboca na moderna teoria instrumentalista da linguagem e de um ideal de um sistema de signos da razão, sendo que à linguagem restou ser nivelada a um puro ser-signo (GADAMER, 2007a, p. 540). Assim, o conceito é uma palavra rígida, recortada da plenitude e largueza de suas relações de significado, o que representa uma violência contra a linguagem, que necessita de certo espaço de jogo (GADAMER: 2007a, p. 536).
} 
formulação lingüística utilizada partir de sua autenticidade e conservar o elemento imaginativo não somente no conteúdo, mas também na forma. Isso para que não se corra o risco de ceder a uma tecnicização da linguagem que rouba justamente sua abertura para possibilidades, engessando a visão de mundo do escritor e do leitor ao invés de ampliar.

Se todo pensar é um dizer-se, a linguagem da qual dispomos determina a forma como pensamos e nossa compreensão do mundo. Nesse sentido, a elaboração das formas estilísticas da literatura contribui para uma complexidade do nosso pensar e compreender, uma vez que os limites de nossa compreensão são estabelecidos pela nossa capacidade lingüística ${ }^{63}$.

A literatura, por conta da relação entre linguagem e o compreender, provoca no leitor a capacidade de compreender, porque a palavra escrita, ao contrário da falada, não possui nenhuma ajuda em sua interpretação. Nela, a palavra fala por si própria e os recursos estilísticos devem nos conduzir a pensar o pensado. Onde a capacidade hermenêutica alcança seu esplendor não é onde os textos estão mal escritos, mas onde a arte da escrita foi exemplar, sem, contudo, ser engessada (GADAMER, 2007a, p. 510). A escrita ressalta de forma muito clara a tarefa da compreensão, porque deve ser compreendida em sua idealidade plena.

\subsection{CONHECIMENTO}

A ciência moderna trouxe, em sua base, uma forma de se relacionar com o mundo que possibilitaria o conhecimento do ser-em-si desse mundo. Esse conhecimento, regido pelas regras do método científico, pressupõe um ideal de objetividade, calcado no homem experimentado como subjetividade.

E como toda relação do homem com o mundo é permeada pela linguagem, não seria diferente com relação ao conhecimento e, mais especificamente, com relação ao conhecimento científico. A linguagem científica regida por códigos, conceitos e enunciados propositivos, e não por uma prática discursiva, opera uma objetivação do

${ }^{63}$ A nossa compreensão nunca apreende em um só golpe do pensar tudo que sabe, somente compreende à medida em que fala. 
mundo. Assim, seria possível o conhecimento do ser em si, que permitiria a posse e o domínio do ente conhecido e o desenvolvimento da técnica ao seu máximo. Esse saber dominador $^{64}$ é o modo próprio das ciências modernas da natureza, não que todo o conhecimento esteja destinado ao domínio do ente ${ }^{65}$ (GADAMER, 2007a, pp. 581-582). A técnica, nesse sentido, possui um papel claro no destino da verdade do ser, todavia um que reside no esquecimento desta. Esse esquecimento, contudo, acarretou a degradação de toda a linguagem e, portanto, da forma como o homem conhece o mundo e a si próprio.

Gadamer procurou libertar do preconceito, imposto pelo ideal de objetividade postulado pela ciência, o modo de ser próprio da arte e da história, componentes fundamentais das ciências humanas, por meio do questionamento acerca de uma hermenêutica universal que define a relação do homem com o mundo (GADAMER, 2007a, p. 614). Procuraremos dar mais um passo nessa direção, ao investigar como a literatura, enquanto elaboração complexa do discurso e da imaginação, pode contribuir para um aguçamento das formas de conhecimento não baseadas na objetivação dos entes, mas na mútua subordinação de homem e mundo.

A primeira questão é: até que ponto se pode procurar a verdade na arte e, mais especificamente na literatura?

No pensar, o ser tem acesso à linguagem e a linguagem é a casa do ser. Nesta habitação do ser mora o homem. Os pensadores e os poetas são os guardas dessa habitação. A guarda que exercem é o ato de consumar a manifestação do ser, na medida em que a levam à linguagem e nela a conservam (HEIDEGGER, 2005, p. 8).

Em outras palavras, a constituição ontológica universal de tudo que se pode compreender é a linguagem. Além disso, o conhecimento é um momento fundamental e inerente ao ser e não um comportamento do indivíduo. Unindo essas duas considerações, o ser da obra literária não é um ser em si, distinto de sua reprodução pela leitura e interpretação, mas sim constituído por ela; somente a partir da leitura e interpretação da obra pelo leitor é que a literatura pode falar e ser compreendida enquanto linguagem, que é seu modo de ser.

\footnotetext{
${ }^{64} \mathrm{O}$ engano é pensado de modo grego como a partir do $\psi \varepsilon v \delta \delta \zeta$ (o dissimulado), ou seja, como dissimular, sobrepor, como esconder, denotando que o engano se dá em virtude de um encobrimento. O falso latino (falsum), pelo contrário, é derivado de fallere, ou seja, de levar à queda, sucumbir, sendo que o modo fundamental dos romanos de relacionar-se com os entes é governando-os pela ordem do imperium, que seria, por seu turno, o comando e a dominação dos entes e de si próprios (HEIDEGGER, 2008c, pp. 71-72). Da acepção romana da verdade é que deriva a verdade alcançada por meio da ciência.

${ }^{65}$ A relação fundamental entre linguagem e mundo não significa que o mundo se torna um objeto da linguagem. O caráter da experiência humana de mundo como tal não tem em mente a objetivação do mundo.
} 
$\mathrm{Na}$ ciência moderna essa idéia não encontra legitimação; seu ideal metodológico garante, a cada um de seus passos, o recuo aos elementos a partir dos quais constrói o conhecimento. Nessa visão, a literatura seria um objeto desvinculado da interpretação pelo leitor, a ser apreendido a partir de uma metodologia distanciada. A hermenêutica vem substituir a consciência estética e histórica, e adquire dimensão de um questionamento universal.

A literatura, constituída também por seu modo de reprodução e entendimento, representa o retorno à mútua subordinação existente entre homem e mundo (GADAMER, 2007a, pp. 590-613). O modo de ser da literatura tem algo de peculiar e incomparável; ela impõe uma tarefa específica para o momento de sua compreensão. Como não há nada de tão estranho e tão exigente à compreensão como a escrita, a compreensão do texto literário repousa em uma segunda criação, como uma reprodução da produção original. Somente com essa recriação é que conseguimos encontrar o significado dessa obra (GADAMER, 2007a, pp. 229-234), ou seja, a partir da fusão de horizontes de escritor e leitor.

Falemos um pouco sobre o compreender como um momento próprio do ser. Compreender não é o ideal último da filosofia, frente à ingenuidade do ir vivendo. Ao contrário, é a forma originária de realização do dasein, na medida em que é possibilidade. A compreensão, dessa forma, é revestida por um caráter de projeto, uma vez que sempre precisamos elaborar um projeto de sentido para o que está sendo compreendido, em relação a nós mesmos. A compreensão alcançada abre novas possibilidades de interpretação, conclusões, decisões que acabamos por tomar. A verdade é que todo compreender acaba sendo um compreender-se, compreender o seu próprio significado no mundo. Aquele que compreende projeta-se rumo às possibilidades de si mesmo (GADAMER, 2007a, p. 349).

O pensamento, que por ventura é um dizer-se, está sempre se renovando e se superando, procurando compreender a partir das mais variadas concepções; trata-se de um caminho rumo às possibilidades em que se exerce a liberdade (GADAMER, 2007a, p. 550). Assim, o próprio pensar é por princípio criativo, assim como a leitura.

O âmbito da verdade do ser é o lugar da liberdade, que se dá em cada qual, porquanto se apóia em uma concepção de verdade compatível com a liberdade do dasein. Gadamer (2007a), em Verdade e Método, contrapõe duas idéias de verdade: a idéia cartesiana, baseada no método, e a idéia do sensus communis, baseado no ideal da eloqüência. $\mathrm{Na}$ antiguidade, a retórica encontrava-se há muito tempo em luta com a filosofia, que pretendia transmitir a verdadeira sabedoria da vida. Evidente que esse 
antagonismo apóia-se também no antagonismo conceitual entre sophia e phronesis, elaborado pela primeira vez em Aristóteles.

O que é importante destacar aqui é que o sensus communis não se alimenta do verdadeiro, mas sim do verossímil ${ }^{66}$ : trata-se de um saber baseado não em razões, mas que permite encontrar o que é plausível, o que poderia acontecer. Representar o que poderia ter acontecido é sugerir o que poderá acontecer e revelar as possibilidades não realizadas do real (PERRONE-MOISÉS, L., 2006a, p. 108). Portanto, somente a imaginação e a memória são capazes de alimentar tal habilidade de desenvolver um sentido para o que é convincente e possível (GADAMER, 2007a, pp. 56-58).

Além disso, o sensus communis teria uma tendência a orientar-se para o amor à comunidade e para a cortesia. Seria muito mais uma virtude social, orientada pelo coração e pela sensibilidade. Assim, enquanto os outros sentidos nos colocam em relação com as coisas, o senso comum presidiria nossa relação com as pessoas. Essa forma de pensar permite que cumpramos a tarefa ética de ajustamento a situações sempre novas exigida pela vida, uma vez que evita o erro dos dogmáticos que estão sempre à busca de leis sociais. Além disso, essa tarefa passa a ser orientada não somente pela racionalidade, mas também por certos sentimentos prévios e inclinações, que se reputam ao coração. Para um conhecimento vivo, portanto, não basta a clareza dos conceitos, é preciso descobrir nas palavras a corrente livre do pensamento. Assim, o sensus communis volta-se contra o puro racionalismo, contra a retaliação da natureza pelo experimento e pelo cálculo, e tem como fundamento a própria vida (GADAMER, 2007a, pp. 62-66). É o que Clarice Lispector (1999, pp. 148-149) chama de sensibilidade inteligente:

E apesar de admirar a inteligência pura, acho mais importante, para viver e entender os outros, essa sensibilidade inteligente. Inteligentes são quase que a maioria das pessoas que conheço. E sensíveis também, capazes de sentir e de se comover. O que, suponho, eu uso quando escrevo, e nas minhas relações com os amigos, é esse tipo de sensibilidade. Uso-a mesmo em ligeiros contatos com pessoas, cuja atmosfera tantas vezes capto imediatamente.

Suponho que este tipo de sensibilidade, uma que não só se comove como por assim dizer pensa sem ser com a cabeça, suponho que seja um dom. E, como um dom, pode ser abafado pela falta de uso ou aperfeiçoar-se com o uso ${ }^{67}$.

\footnotetext{
${ }_{67}^{66}$ Já Aristóteles, em sua teoria da representação poética, defendia não a veracidade, mas a verossimilhança.

67 A literatura exercita, portanto esse dom que chamamos aqui de sensus communis. A visão da literatura como uma forma de diálogo que há de ser abordado num capitulo posterior aprofunda ainda mais essa visão do outro e a forma de se relacionar com ele que descreve Lispector. Isso constitui parte da dimensão ética da experiência literária.
} 
O pensamento desenvolvido na literatura também tem por base a vida, porque ela interpela o leitor como uma experiência. Estar postado na clareira do ser também é vigilância, é o cuidado pelo saber, que significa um pensar num questionar em busca de experiência e que abandona as opiniões correntes da filosofia (HEIDEGGER, 2005, p. 24). A experiência faz parte da essência histórica do homem e não pode ser poupada a ninguém. Segundo Jeannette Maman (2003, p. 54), “nossa existência é temporal, a história é o conteúdo fático feito de acontecimentos que se situam nessa experiência humana, que tem uma memória ou presença do passado e uma projeção para o futuro.” Assim, a literatura imita a própria existência e condensa a experiência do tempo - presente, passado e futuro em virtude de sua autonomia e da forma como ocorre sua interpretação, de forma que compreendamos a nossa existência em sua totalidade. Mesmo porque a vida teórica, que afasta-nos dos instrumentos de trabalho e nos isola a certa distância, alicerça-se no solo da vida prática.

A experiência é fonte de aprendizado e conhecimento na medida em que frustra expectativas. Muitas vezes, o aprendizado fruto da experiência chega a frustrar até mesmo as expectativas mais críveis, às quais nos ligamos por estarmos presos a dogmas (GADAMER, 2007a, pp. 465-467). Nesse sentido, a experiência autêntica é sempre um momento de auto-conhecimento e de desenvolvimento da virtude do sensus communis.

Agora, de que maneira se dá a experiência da vida e da verdade na obra literária?

A verdade não resulta da meditação, da especulação e das razões internas ou dos dados empíricos, da análise lógica ou lingüística do texto, mas da ação compreensiva (MAMAN, 2003, p. 111). Na apreciação de uma obra literária não existe a preocupação em saber se aquilo que se lê é real ou relato fiel da realidade, uma vez que a obra está falando uma verdade superior. A alegria frente à compreensão da obra é a alegria do conhecimento. $\mathrm{Na}$ verdade, a transformação em configuração de que tratáramos antes é transformação no verdadeiro. Assim, na representação literária é possível extrair aquilo que em outras ocasiões está encoberto, emerge o ser. Na representação, o ser das coisas se realça, juntamente com o nosso próprio ser.

A entrega do leitor à verdade da obra possui a liberdade como origem, sendo que toda crença é livremente consentida. O leitor faz-se crédulo e esta credulidade é acompanhada a cada instante pela consciência de ser livre (SARTRE, 2006, pp. 41-42). A palavra interpretadora do texto literário é a palavra do leitor. Assim, o leitor se apropria da obra literária e realiza uma recriação pelo compreender. Sempre, portanto, existe uma 
relação do sentido do texto com o eu que compreende: existe uma unidade entre interpretação e compreensão, sendo que a interpretação faz parte da articulação interna do sentido (GADAMER, 2007a, pp. 610-611).

Interessamo-nos por uma obra literária na medida em que conhecemos e reconhecemos algo de nós mesmos e de nosso mundo na representação. Assim, o sentido cognitivo da representação mora no reconhecimento (GADAMER, 2007a, pp.168-169). Por conseguinte, a obra realça alguns pontos que já conhecemos a respeito de nós mesmos e nos mostra outros que estavam, até então, ocultos: faz-nos compreender como nossos sentimentos e pensamentos são ${ }^{68}$. Fica claro que esse olhar sobre nós mesmos a partir de algo que se encontra fora de nós e que foi criado por outra pessoa tem o duplo papel tanto de esclarecer nossa identidade e nossas perspectivas de decisões futuras, quanto de fazer com que nos aproximemos do outro: tão semelhante a nós.

No caso da literatura o outro é trazido pelo personagem em quem enxergamos muito de nós mesmos ${ }^{69}$, pelo eu lírico da poesia, ou como nas narrativas em primeira pessoa, nas quais narrador e personagem se confundem assemelhando-se muito ao eu lírico, o que torna o reconhecimento ainda mais poderoso. Lispector, por exemplo, tem uma capacidade imensa de descrever as minúcias do que se passa no interior de seus personagens, sendo possível sentir o que eles sentem de forma muito verdadeira; quase confundimos o que está sendo expresso com o que estamos de fato sentindo. Segundo Gadamer (2007a, p. 174), "para o conteúdo da experiência como tal é indiferente se a cena trágica ou cômica que se desenrola diante de alguém está acontecendo no palco ou na vida.”

A representação da ação trágica, por exemplo, atua através de $\operatorname{eleos}^{70}$ e phobos $^{71}$, ocorrências que nos vêm de assalto e nos arrastam consigo. A desolação e o temor são formas de estar fora de si que atestam o efeito daquilo que se representa para nós (GADAMERa, 2007, p. 189). Dessa elevação, contudo o público não volta ao seu verdadeiro ser, mas, ao contrário, encontra esse ser na comoção e carrega essa compreensão mesmo quando o livro ou as cortinas já se fecharam. Além disso, o encontro consigo mesmo é facilitado pelo reconhecimento e compreensão da tradição à qual leitor e obra literária pertencem e pela linguagem que seja compreensível e comovente ao leitor.

\footnotetext{
${ }^{68}$ Com relação principalmente aos sentimentos é importante o fato de que esses são descritos em palavras, na linguagem do entendimento.

${ }^{69}$ Mesmo quando não podemos ver características parecidas com as nossas, capturamos nos personagens, não necessariamente em um único, sentimentos, expectativas e pensamentos nossos.

${ }^{70}$ É a desolação que advém a alguém em face daquilo que chamamos de desolador.

${ }^{71}$ Significa o espanto e o tremor que se apossa de nós quando vemos alguém ir às pressas de encontro a sua ruína.
} 
A tragédia proporciona a experiência, isto é, a quebra de expectativas por meio do sofrer, tanto dos personagens quanto dos expectadores que se entregam à estória. No fundo a tragédia ensina, por meio desse impacto do sofrimento, os limites do ser humano; proporciona, portanto, a experiência da finitude. E esta é a experiência por excelência, porque toda experiência como frustração de expectativas é a tomada de consciência dessa limitação, que é o auto-conhecimento mais importante para uma consciência existencial. Esta consciência da historicidade humana nos torna capazes de reconhecer tanto nossos limites quanto os horizontes nos quais ainda há possibilidades de futuro e de planos. É no amor, no ódio, na cólera, no medo, na indignação, na admiração, na esperança, no desespero que o homem e o mundo revelam-se em sua verdade.

Os dramas Shakespereanos, que neste ponto se assemelham demais às tragédias, quase sempre levantam a questão da identidade, a partir da qual nos perguntamos, juntamente com os personagens: “quem eu (nós) sou (somos)?”. Esta questão se trata de uma questão bastante onerosa e inevitável aos personagens de Shakespeare, uma vez que estes ousam encontrar o acesso ao todo de suas vidas e aos estranhos túneis onde as experiências foram enterradas e aguardam ser revividas (CHUEIRI, 2004, p. 62).

Os dramas, desde as tragédias, trazem em sua estrutura a ação e especialmente o conflito; e nada pode ser mais dramático e conflituoso do que as experiências de ser e tornar-se que permeiam os dramas de Shakespeare. Em O mercador de Veneza, por exemplo, as palavras de Antonio, desde o início da peça até o seu fim, apontam para sua dificuldade em conhecer-se, para o estranho que ele é em relação a si mesmo e para a não pertença a lugar algum, sequer a Veneza. Nesse sentido, a o gênero da peça, que pendula entre a comédia e a tragédia, nesse ponto aproxima-se incrivelmente da tragédia, por trazer o ser e o tornar-se em sua forma e matéria, mesmo porque o tempo da peça não está circunscrito ao tempo da ação, mas obedece à temporalidade subversiva das questões existenciais e da melancolia (CHUEIRI, 2004, pp. 62-65).

O homem experimentado distingue-se daquele que está preso a dogmas. O escritor, para representar seu mundo de forma autêntica e produzir um conhecimento como aqui se pretende esboçar, deve, portanto, suspender tudo o que aprendeu e ver como se tudo isso fosse novo e desconhecido. A soma de todas as experiências, da sua intuição, do pensamento e da sensibilidade aparece como se fosse a primeira vez. O escritor passa a ver tudo em sua surpresa, o que o impede de aceitar qualquer coisa como dada e partir de qualquer ponto positivo. 
A experiência não é inicialmente desprovida de palavras, mas faz parte dela própria encontrar as palavras que a expressem, de modo que a "coisa experimentada" venha à fala (GADAMER, 2007a, p. 539). A literatura é ela mesma uma experiência que já vem à fala a partir de seu modo de ser originário. Ela não só é elaborada pelo escritor que cria e explora a corrente livre do pensamento em suas palavras, como também pelo leitor que recria esse pensamento e vivencia a experiência literária, trazendo-a a fala.

As coisas que conhecemos são todas expressáveis, até mesmo aquelas que só apreendemos pré-conceitualmente. No $§ 34$ de Ser e Tempo, Heidegger define o discurso como a forma de colocar a inteligibilidade ${ }^{72}$ em palavras, ou seja, articulá-la expressivamente. O entendimento pré-conceitual das coisas não é menos importante do que o cognitivo que parte da interpretação que é formulada enunciativamente. Lispector (1999, p. 119) retrata uma experiência do contato entra a mulher e o mar da seguinte forma:

Aí está ele, o mar, a mais ininteligível das existências não humanas. E aqui está a mulher, de pé na praia, o mais ininteligível dos seres vivos. Como o ser humano fez um dia uma pergunta sobre si mesmo, tornou-se o mais ininteligível dos seres vivos. Ela e o mar.

Só poderia haver um encontro de seus mistérios se um se entregasse ao outro: a entrega de dois mundos incognoscíveis feita com a confiança com que se entregariam duas compreensões.

(...) Ela está sozinha. O mar salgado não é sozinho porque é salgado e grande, e isso é uma realização. Nessa hora ela se conhece menos ainda do que conhece o mar. Sua coragem é a de, não se conhecendo, no entanto prosseguir. É fatal não se conhecer, e não se conhecer exige coragem.

Para Lispector, portanto, o mar é ininteligível, mas supomos que o que ela descreve como ininteligibilidade seja na verdade a impossibilidade de uma cognição que gera interpretações e proposições. Contudo, o encontro representado no texto resulta em um conhecimento pleno, todavia pré-conceitual e que exige uma entrega e uma mútua subordinação entre a mulher e o mar. A conclusão desse trecho denota que a mulher não conhece a si própria antes de entrar em contato com o mar e só se conhecerá à medida que entrar em contato com o mundo. Por fim, esse excerto da crônica só demonstra a forma como a compreensão pré-conceitual se dá.

\footnotetext{
${ }^{72} \mathrm{Na}$ segunda frase do $\S 34$, Heidegger esclarece que a inteligibilidade das coisas sempre esteve articulada, antes mesmo de termos feito uma interpretação. Essa inteligibilidade é pré-conceitual e surge a partir da situação holística à qual pertencem os entes. Essa situação holística é desvelada a partir de um entendimento que é mais fundamental que a interpretação conceitual dela. Isso não quer dizer, contudo, que esse entendimento por meio do qual nos aproximamos do mundo seja uma massa indiferenciada. Muito pelo contrário, possui uma estrutura; esta estrutura, todavia, é pré-conceitual.
} 
A cognição é uma forma de interpretação, porque seu conteúdo é propositivo por natureza. Porque é propositivo, pode ser expresso em um enunciado. A pré-cognição é, por seu turno, discursiva. Isso é mais do que dizer que a cognição é mediada pela linguagem. $\mathrm{Na}$ realidade, toda vida humana é mediada pela linguagem, contanto que consideremos uma concepção de linguagem ampla o bastante.

A maior parte de nosso entendimento, e, portanto, de nosso discurso, é superficial, ou seja, esse tipo de conhecimento é o suficiente para navegarmos no mundo, uma vez que é impossível que estejamos familiarizados com o mundo todo. Assim, esse entendimento suficiente e o discurso superficial que o expressa são constitutivos do nosso cotidiano. Entretanto, pode existir uma degradação desse discurso superficial: quando essa fala perde sua relação primária com o ser-junto-ao ente sobre que se fala, ou nunca atingiu essa relação, não comunica de modo que o ente seja apropriado da forma como ele é em si, mas sim na forma de repetição. A superficialidade agrava-se e chega à completa falta de profundidade. Essa superficialidade sugere que o discurso tornou-se completamente desvinculado das experiências que o justificam. Por todo o exposto, quando o discurso se degrada, também o entendimento se degrada, mantendo-se na superficialidade do conhecimento, ou na pura e simples objetivação dos entes.

Nesse sentido, a literatura opera um resgate e uma reconstrução do discurso, trazendo à linguagem e nela mantendo o ser. O pensamento dessa forma chega ao seu ideal de elaboração e pode construir sentidos e explorar os seus caminhos. A literatura é um discurso que se vale de inúmeros recursos lingüísticos que extrapolam, e muito, os conceitos e os enunciados. Alguns deles têm por base a metáfora, que é uma das formas primárias de entendimento do mundo e outros têm por base o próprio jogo do expresso e do não-expresso. A poesia é o gênero literário que realiza essas duas formas de expressão de forma mais exemplar, o que não significa que outras manifestações de toque poético ou ficcional, como a crônica, os contos, os romances e a dramaturgia, não façam uso abundante desses recursos. Em todo caso, são todas construções lingüísticas que escapam ao dogmatismo ${ }^{73}$.

\footnotetext{
${ }^{73}$ Vale ressaltar que na prosa imperam mais os signos do que na poesia, sendo esta mais próxima ao inefável. Assim, segundo Sartre (2006, p. 14): "Mas se o poeta se detém nas palavras, como o pintor nas cores ou o músico nos sons, isso não quer dizer que aos seus olhos elas tenham perdido todo significado; de fato, somente o significado pode conferir às palavras sua unidade verbal; sem eles, os vocábulos se dispersariam em sons ou em traços de pena. Só que também ele se torna natural; (...) é uma propriedade de cada termo, análoga à expressão de um rosto, ao pequeno sentido, triste ou alegre, dos sons e das cores. Fundido à palavra, absorvido pela sua sonoridade ou pelo seu aspecto visual, adensado, degradado, o significado também é coisa, incriada, eterna; para o poeta, a linguagem é uma estrutura do mundo exterior."
} 
Hoje, o conhecimento que não é considerado ciência, como a filosofia, por exemplo, não é priorizado (DERRIDA, 2002, p. 341). Ao mesmo tempo, a arte é relegada ao espaço do lazer, que deve ser fruído nos momentos de total abandono da atividade intelectual, esta reservada aos espaços de produção. A leitura atenta, concentrada, enquanto instrumento para a educação-formadora de tradição humanista, foi decretada inútil por seu anacronismo em uma época voltada ao consumo material e intelectual, bem como ao espetáculo midiático. A leitura deixou de ser referência em diversas instâncias, pois não pode circunscrever-se na contração do tempo do mercado, do consumo e das tecnologias (MATOS, 2006).

Todavia, o conhecimento científico não cumpriu a promessa de segurança e bemestar. Em seu lugar, há a passividade e a angústia existencial da perda de controle da natureza e do mundo e do medo de destruição, relacionando-se ao "delírio" no lugar da ética, que se vincula ao campo da escolha, da compreensão e da liberdade. Desse modo será possível chamar de irracionalismo o ato de conduzir o pensar ao seu elemento?

Como vimos, no discurso se expressa o significado, o sentido dos entes no mundo. A significação, como a totalidade desses significados, é o que é articulada no discurso. Assim, somente por conta dele é que podemos experimentar um mundo estruturalmente articulado. A recondução do pensamento ao ser e o desenvolvimento da linguagem discursiva não são o irracionalismo, mas sim o exercício da racionalidade da forma mais verdadeira e completa, em harmonia com a sensibilidade.

Apesar de a verdade da coisa não se encontrar no próprio nome, isso não significa que o pensamento poderia prescindir de usar o nome. Contudo, as palavras individuais só alcançam seu significado e sua relativa univocidade na unidade do discurso, assim como também o conhecimento verdadeiro só pode ser alcançado nessa estrutura (GADAMER, 2007a, p. 555).

Dessa forma, o poeta, que fala por meio do discurso poético, em vez de conhecer as coisas antes por seus nomes, parece que tem com elas antes um primeiro contato silencioso e, em seguida, voltando-se para as palavras, tocando-as, tateando-as, palpando-as, nelas descobre uma pequena luminosidade própria com os entes: a terra, o céu, a água. E não sabendo servir-se da palavra como signo correspondente ao ente, a imagem verbal que escolhe para expressar essa pré-cognição do mundo não é necessariamente aquela que usualmente se utiliza para denominar o ente, como a palavra salgueiro, para a árvore 
salgueiro, ou a palavra quadrado para determinar a forma geométrica de quatro lados equivalentes, posicionados cada qual em um ângulo reto em relação ao outro. Como o poeta já está fora, ele não necessita de palavras que lhe sirvam de indicadores para lançá-lo para fora de si mesmo, para o meio das coisas. Basta que ele se movimente com naturalidade, sendo a linguagem inteira o espelho do mundo que ele construirá em seu discurso. Assim, a palavra poética é um microcosmo e não resta duvida que a crise da linguagem que eclodiu no início do século XX é uma crise poética e quaisquer que tenham sido seus fatores sociais e históricos ela se manifestou na despersonalização do escritor em face das palavras (SARTRE, 2006, pp. 14-17).

Conforme dizíamos, a metáfora, que é natural da construção lingüística ${ }^{74}$, quando subordinada à gramática e à lógica demonstrativa, passa a ser instrumentalizada como figura retórica, relegada à margem. A literatura recupera o papel central da metáfora na compreensão, frente aos conceitos. Evidentemente que a metáfora continua fazendo parte de nosso discurso cotidiano; assim, mesmo quando a explicação copernicana penetrou em nosso saber, "o sol não deixou de se pôr para nós" (GADAMER, 2007a, p. 579). Contudo, a metáfora aos poucos vai perdendo importância, inclusive nos discursos cotidianos. A literatura é uma expressão que a conserva e desenvolve.

Sendo o que caracteriza a relação do homem com o mundo sua liberdade frente ao mundo circundante, essa liberdade implica também a liberdade frente aos nomes que damos às coisas. A metáfora é uma das formas que mais exercita a capacidade livre para a linguagem, permitindo o exercício de múltiplas e criativas formas de expressar o entendimento e caracterização. A poesia de Homero e Hesíodo, por exemplo, possibilitou a eternização sistematizada das figuras dos deuses gregos, conferindo unidade à consciência religiosa. Todavia, o poético, ao trazer algo à representação, mantém sempre uma nãofixação peculiar que deixa o campo aberto para um preenchimento pela imaginação.

Friedrich Nietzsche (1992) afirmou em sua obra $O$ nascimento da Tragédia ou Helenismo e Pessimismo que as denominações como as extraídas dos mitos gregos, como apolíneo e dionisíaco, por exemplo, tornam perceptíveis à mente perspicaz os profundos ensinamentos secretos de sua visão de mundo. Não, a bem dizer, por meio de conceitos,

\footnotetext{
${ }^{74}$ Conceituação originária e espontânea que parte da identificação da semelhança entre as coisas: vivo caráter metafórico da linguagem. A articulação de palavras e coisas que cada língua empreende à sua maneira representa em todos os momentos uma primeira conceituação natural, distante da científica. Guia-se pelo aspecto humano das coisas, seguindo o sistema de suas necessidades e interesses. A abundância das designações populares para determinados objetos vai sendo nivelada cada vez mais, em parte pela influência da transitoriedade da vida moderna, em parte pela standardização da ciência e da técnica (GADAMER, 2007a, p. 562).
} 
mas por meio das figuras penetrantemente claras de seu mundo dos deuses. Nesse sentido, a literatura, suas figuras de linguagem e suas personagens estão muito próximos dos mitos, que trazem seus ensinamentos por meio de personagens arquetípicos, denominações alegóricas e de narrativas, ao invés de conceitos e enunciados.

O que é dito desse modo é o que primordialmente pode ser dito. É a fala autêntica,

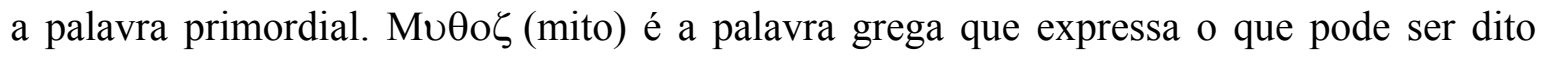
antes de tudo o mais, na pré-concepção, sendo sua essência determinada com base na aletheia. A palavra do mito é, portanto, a que revela, descobre e deixa ser visto; especificamente, ele deixa aparecer o que se mostra a si mesmo, previamente em todas as coisas (HEIDEGGER, 2008c, pp. 92-93).

Em nossa civilização o mito tomou o sentido de algo puramente imaginário, não adequado aos postulados científicos, e, portanto, mentiroso. A veritas e a aletheia significam não só duas concepções diferentes da verdade, mas duas formas de buscá-la, sendo que o modo literário de buscar a verdade continua sendo o modo simbólico do mito (PERRONE-MOISÉS, L., 2006a, p. 106). O que vimos tentando demonstrar neste capítulo é que tudo depende do fato de a verdade do ser atingir a linguagem, estando a essência da palavra fundada na aletheia, onde a poesia e o pensamento são o fundo da relação primordial com o encoberto. Assim, mais do que de outra maneira, o pensar estaria livre do mero pressentimento e do opinar e seria entregue à tarefa da escritura, que se tornou rara. A literatura consegue, em grande medida, aproximar a linguagem dessa verdade.

Evidentemente que somente o homem é capaz de realizar essa tarefa, uma vez que as plantas e os animais estão mergulhados, cada qual no seio de seu ambiente próprio, mas nunca estão inseridos livremente na clareira do ser, por isso falta-lhes linguagem. Em sua essência, a linguagem não é nem exteriorização, nem expressão de um ser vivo, por isso ela não pode ser pensada em seu valor de signo. A linguagem é advento iluminadorvelador do próprio ser (HEIDEGGER, 2005, pp. 27-28). A interpretação metafísicoanimal $^{75}$ da linguagem oculta sua essência ontológico-historial ${ }^{76}$. Trata-se de pensar a essência da linguagem a partir da correspondência ao ser, ou seja, enquanto habitação da essência do homem (HEIDEGGER, 2005, p. 38).

O destino do mundo anuncia-se na poesia, sem que ainda se torne manifesto como a história do ser. Quando a poesia opera uma síntese entre a tradição, o presente e o futuro,

\footnotetext{
${ }^{75}$ Linguagem como unidade de fonema (grafema), melodia e ritmo, e significado.

${ }^{76}$ Será mais profundamente abordada no capítulo 4 . Só nos adiantamos dizendo que o tempo da poesia é o tempo do ser.
} 
entra-se em contato com o tempo do ser, que transcende o tempo humano finito ${ }^{77}$. Dessa maneira, a poesia, além de fazer com que os homens compreendam sua mortalidade, mostra como seu entendimento e conhecimento pode perdurar. Ao se ter consciência da contingência da opinião pública e do mundo circundante é mais fácil superá-los e tornar-se autêntico.

O enunciado, assim como o conceito, não vai ao encontro da experiência humana do mundo. O pensamento permanece na dimensão do que é enunciado e não alcança a dimensão da experiência de mundo que se dá por meio da espontaneidade do discurso. Dizer o que se tem em mente, fazer-se compreender, deixa vir à fala uma relação com o todo do ser: unidade de sentido do que foi dito com o não dito. A escolha de palavras repousa em um número de possibilidades finitas, todavia, a orientação deve ser rumo ao infinito, ao todo de sentido do dito e do não dito (GADAMER, 2007a, p. 605). Nas palavras do escritor de ficção por excelência, que fazia a fantasia delicadamente perpassar a realidade, Borges (2001, p. 169):

Chego, agora, ao inefável centro de meu relato; começa aqui meu desespero de escritor. Toda linguagem é um alfabeto de símbolos cujo exercício pressupõe um passado que os interlocutores compartem; como transmitir aos outros o infinito Aleph, que minha temerosa memória mal e mal abarca? Os místicos, em análogo transe, são pródigos são pródigos em emblemas: para significar a divindade, em persa fala de um pássaro que, de algum modo, é todos os pássaros; Alanus de Insulis, de uma esfera cujo centro está em todas as partes e a circunferência em nenhuma; Ezequiel, de um anjo de quatro faces que, ao mesmo tempo, se dirige ao Oriente e ao Ocidente, ao Norte e ao Sul. (Não em vão rememoro essas inconcebíveis analogias; alguma relação tem com o Aleph.) É possível que os deuses não me negassem o achado de uma imagem equivalente, mas este relato ficaria contaminado de literatura, de falsidade. Mesmo porque o problema central é insolúvel: a enumeração, sequer parcial, de um conjunto infinito.

Neste trabalho são utilizados com freqüência alguns trechos as obra de Borges, porque além de ser um escritor literário autêntico, cuja obra nos arrebata por trazer a experiência literária, seu discurso é repleto de filosofia e de metalinguagem acerca da tarefa da escritura. Assim, nessa passagem ele indica que realmente o ato de escrever implica uma escolha das palavras e da forma como as utilizaremos. Essa escolha deve procurar interpelar o leitor e transmitir-lhe o que queríamos representar, o todo de significado. Todavia, não necessariamente mais palavras nos ajudarão a transmitir um sentido maior, tendo em vista que a representação repousa justamente nessa escolha. Por isso mesmo que as poucas e

\footnotetext{
${ }^{77} \mathrm{O}$ modo de ser temporal da literatura será mais profundamente abordado no capítulo 4.
} 
sempre finitas palavras de um texto literário tendem ao infinito e contém um todo, assim como o Aleph: um todo de significado, exasperando o signo. Repara-se que na descrição do que Borges viu, ele optou por algumas imagens, todavia, aquelas imagens carregam o infinito: em sua "sequer parcial" visão de mundo existe o todo.

Conforme explicação anterior, toda vez que a palavra assume a função de mero signo, o nexo originário entre falar e pensar se transforma numa relação instrumental. Essa transformação forma a base para todos os conceitos de ciência (GADAMER, 2007a, p. 559). A lógica formal e a gramática são formas de domínio do subjetivismo sobre a linguagem. Desse modo, a libertação da linguagem dos grilhões da gramática e a abertura de um espaço essencial mais original está reservado como tarefa para o pensar e o poetizar. Evidentemente que a poesia é a forma mais originária e pura de literatura, contudo o poetizar pode ser mais amplo que a mera poesia. Deve ser considerado poetizar, nesse sentido, toda a literatura que busque essa libertação.

Pensamos que essa libertação deva envolver todas as estruturas da obra literária, tanto as que dizem respeito ao conteúdo e estrutura da obra quanto as que dizem respeito à forma e aos recursos estilísticos. Contudo, isso não significa que sejam abandonadas as formas de organização da mensagem que garantem seu impacto e perenidade, bem como colaboram para a organização dos pensamentos e sentimentos tanto do escritor como do leitor; só se precisam buscar formas que façam uso de recursos que não rumem em direção ao enunciado rígido, mas para o discurso, para a metáfora e para o todo de significado da obra.

De acordo com Heidegger, o discurso compreende não só as palavras e sua gramática, mas a forma como usamos a linguagem para nos comunicarmos. O próprio silêncio (não dito) é uma possibilidade do discurso. Não é à toa que no poema originário de Parmênides, a essência da deusa Aletheia está presente em toda a construção do dito, em cada um de seus versos, mas, antes de tudo, puramente, em sua frase introdutória, a qual justamente é o silêncio do nomẹ Aletheia (HEIGEGGER, 2008c, p. 46):

\section{I, $22-25$}

$22 \mathrm{E}$ a deusa me acolheu com simpatia; ela tomou minha mão direita na sua; então ela falou a palavra e se dirigiu para mim neste modo: "Ó homem, companheiro de imortais condutoras de carro, 
Dentre as formas orais e escritas da literatura, na poesia é onde o silêncio se pronuncia melhor. Essa comunicação envolve bem mais do que semântica em um sentido estrito; envolve tudo que convém no uso da linguagem.

O acontecer lingüístico da palavra poética expressa, de um modo misterioso, uma relação própria com o ser. Friedrich Hölderin mostrou que encontrar a linguagem de um poema pressupõe a dissolução de todas as palavras e modos de falar habituais (GADAMER, 2007a, p. 606). A enunciação poética não copia uma realidade que já é, mas apresenta uma nova visão de um novo mundo no âmbito imaginário da invenção poética. A expressão poética traz um sentido incorporado por completo na enunciação.

Ao escrever um poema magnificamos alguns aspectos do real, desprezando outros; ademais, a forma imprime um ritmo às palavras, como um convite a ritmar o mundo, criar harmonias de som e de sentido que não se percebem na fala corrente. $\mathrm{O}$ poema, como uma dissimulação, encobre e cifra momentaneamente o mundo e seu sentido, todavia convida a desencobrir, por meio de uma captação do particular, a plenitude do mundo (PERRONEMOISÉS, L., 2006a, pp. 105-106).

Conclusivamente, o comportamento científico e a filosofia que tenha por base explicações e fundamentações fazem crer que a verdade do ser também possa ser fundamentada no bojo de um sistema lógico causal, ou, o que dá no mesmo, sobre a impossibilidade de sua apreensão. Dessa forma, Heidegger afirma que caso o homem encontre, algum dia, o caminho para a proximidade do ser deve aprender a existir no inefável.

Assim como Lispector escuta o apelo do mar que não pode apreender, o homem precisa primeiro aprender a escutar o apelo do ser, sempre sob o risco de, dócil a este apelo, pouco ou raramente restar algo a dizer, como na enunciação poética, em que o silêncio traz a completude ao sentido. Aqui também Lispector (1999, p.112) nos presenteia com uma reflexão de escritora autêntica que era:

\footnotetext{
AINDA SEM RESPOSTA

Não sei mais escrever, perdi o jeito. Mas já vi muita coisa no mundo. Uma delas, e não das menos dolorosas, é ter visto bocas se abrirem para dizer ou talvez apenas balbuciar, e simplesmente não conseguirem. Então eu quereria às vezes dizer o que elas não puderam falar. Não sei mais escrever, porém o fato literário tornou-se aos poucos tão desimportante para mim que não saber escrever talvez seja exatamente o que me salvará da literatura.
} 
O que é que se tornou importante para mim? No entanto, o que quer que seja, é através de literatura que poderá talvez se manifestar.

Somente assim será devolvido à palavra o valor de sua essência e o homem será agraciado com a casa do ser, que é a linguagem (palavra) ${ }^{78}$, e, portanto, com o verdadeiro conhecimento (HEIDEGGER, 2005, p. 16). O saber essencial não domina o que lhe é dado saber, mas é tocado por ele, enquanto que cada ciência é um conhecimento de dominação, um sobrepujar e um ultrapassar o ente, realizando-se no modo da objetivação. Em contrapartida, o saber essencial é um retroceder diante do ser. Numa tal atenção ${ }^{79}$ percebemos essencialmente mais, ou seja, algo completamente diferente do produto notável da ciência moderna, pois esta última é sempre um assalto técnico ao ente e uma intervenção orientada para a produção e para a ação operosa e comercial. Nada melhor para ilustrar essas idéias do que um poema:

GUARDAR $^{80}$

Guardar uma coisa não é escondê-la ou trancá-la. Em cofre não se guarda coisa alguma. Em cofre perde-se a coisa à vista.

Guardar uma coisa é olhá-la, fitá-la, mirá-la por admirá-la, isto é, iluminá-la ou ser por ela iluminado.

Guardar uma coisa é vigiá-la, isto é, fazer vigília por ela, isto é, velar por ela, isto é, estar acordado por ela,

isto é, estar por ela ou ser por ela.

Por isso melhor se guarda o vôo de um pássaro

Do que um pássaro sem vôos.

Por isso se escreve, por isso se diz, por isso se publica, por isso se declara e declama um poema:

Para guardá-lo:

Para que ele, por sua vez, guarde o que guarda: Guarde o que quer que guarda um poema:

Por isso o lance do poema:

Por guardar-se o que se quer guardar

(CÍCERO, 1997).

\footnotetext{
${ }_{78}$ Os gregos possuíam diversas palavras para palavra, mas nenhuma para linguagem, uma vez que não pensavam a palavra com base na língua por meio da qual é falada. Portanto, sua determinação da essência do homem não é de um ser vivente que possui uma língua, mas a palavra preserva a relação do ser com o homem, enquanto um ente que se relaciona com os entes enquanto tais. Contudo, essa palavra deve ser originária, seguir a gramática do mito poético, expressar o encobrimento e desencobrimento do ser, e não realizar afirmações assertivas, enunciados verdadeiros (no sentido da veritas romana).

${ }^{79}$ O olhar não é como atividade e ato do "sujeito", mas o vislumbre como emergir do ente e seu ir ao encontro: "ver é automostrar-se e, na verdade, aquele automostrar-se no qual a essência da pessoa que encontra se reúne em si (...)" (HEIDEGGER, 2008c, p. 151)

${ }^{80}$ Guardar significa olhar em italiano.
} 
Contudo, a primazia da lógica racional sobre o pensar originário intangível é tão forte que até mesmo Kant sugere a falsa aparência de que o conceito precede a idéia estética; no entanto, não é o entendimento, mas a imaginação que detém o controle do jogo das capacidades. É ela que põe em movimento, estimula em sua liberdade o entendimento e a capacidade das idéias intelectuais (a razão) (GADAMER, 2007a, p. 95). Desse modo, não há razão sem imaginação. Mesmo assim surge a suspeita infundada de que o pensar e o conhecer da forma como aqui propomos se tornaria vítima da arbitrariedade, tendo em vista que não se pode encontrar apoio no ente. Contudo, a poesia que se aproxima e realiza esse modo de pensar é mais verdadeira do que a investigação do ente pela ciência e pelos enunciados (HEIDEGGER, 2005, p. 83).

Por fim, um último questionamento: pensar a verdade do ser seria, portanto, um representar teórico do ser e do homem, ou é possível retirar, ao mesmo tempo, de tal conhecimento, indicações para a vida ativa? É neste momento que nos encontramos em um ponto limítrofe entre reflexão acerca do conhecimento e a reflexão ética. A resposta de Heidegger é: esse pensamento não é nem teórico nem prático. Como explicado no capítulo anterior, tal pensar não chega a um resultado, isto é, não produz efeito. Trata-se, por esse motivo, de um conhecimento mais livre do que o da verdade das ciências, porque permite que o ser seja. É um pensar que foge à ciência salvando-se na poesia (HEIDEGGER, 2005, pp. 76-77).

\subsection{VALORES E ÉTICA}

De fato, o modo de conhecer proporcionado pela literatura não possui qualquer indicação acerca de quais atitudes são as mais adequadas ou mais corretas para determinada situação em que nos encontramos. Contudo, será que a contribuição da literatura para a reflexão ética não seria justamente essa? A literatura nos faz pensar as questões éticas de forma dialógica ${ }^{81}$, uma vez que a ética não se trata de um código de

\footnotetext{
${ }^{81}$ As situações dramáticas trazidas na literatura não podem escapar à sua natureza conflituosa, mais do que podem escapar à sua estrutura dialógica. Quando os personagens (e os leitores que com eles experimentam seus próprios conflitos) pergunta sobre sua identidade, ele imediatamente enfrenta um conflito e um diálogo é travado quer consigo quer com o outro. Mesmo que o diálogo almeje o estabelecimento de certos consensos, referidos consensos podem ser extremamente antagônicos e conflituosos. Uma das lições mais melancólicas da poesia é de como falamos conosco mesmos (CHUEIRI, 2004, pp. 62-63).
} 
valores a ser seguido, mas sim de caminhos a serem escolhidos em liberdade, que devem, portanto, ser adequadas tanto às situações particulares, quanto à pessoa que as toma.

A leitura é tida como a prática mais nobre da educação humanista por prover uma dimensão ética, uma vez que só se pode saber do amor, do ódio, dos valores e sentimentos éticos se estes já tiverem sido articulados em palavras e a literatura com certeza o faz e os traz à nossa experimentação (MATOS, 2006). Cada sociedade cria as suas manifestações ficcionais, poéticas e dramáticas de acordo como os seus impulsos, as suas crenças, os seus sentimentos, as suas normas, a fim de fortalecer em cada um a presença e atuação deles. Os valores que a sociedade preconiza, ou os que considera prejudiciais, estão presentes nas diversas manifestações da ficção, da poesia e da ação dramática. A literatura fornece assim a possibilidade de vivermos dialeticamente os problemas, visto que confirma e nega, propõe e denuncia, apóia e combate os conceitos e valores por ela trazidos.

O novo e o antigo, o instituinte e o instituído sempre estão presentes nas obras literárias. O movimento entre eles é realizado inclusive do ponto de vista de sua forma, e não somente com relação às matérias tratadas, tendo em vista que existe a literatura de agregação e a literatura de segregação. A primeira procura incorporar-se a um sistema simbólico vigente, utilizando o que está estabelecido como forma de expressão de determinada sociedade. A segunda se preocupa em renovar um sistema simbólico, criar novos recursos expressivos. É claro que os dois processos são complementares e acabam por equilibrar-se, privilegiando em maior ou menor grau a participação no conjunto de valores comuns da sociedade ou dos que tendem a acentuar as peculiaridades. Evidentemente que com a autonomia adquirida pela obra literária esses dois elementos tornam-se ainda mais fluidos e independentes dos valores de determinada sociedade. Contudo, é evidente que os valores passados, caso não sejam mais vigentes no presente momento, certamente que compõem o arcabouço da tradição.

Por conta disso, em vista da ética, a questão colocada anteriormente com relação à gratuidade da literatura e sua liberdade em vista de conceitos se torna mais complexa. Anteriormente, chegáramos a uma conclusão muito semelhante ao consenso atingido por

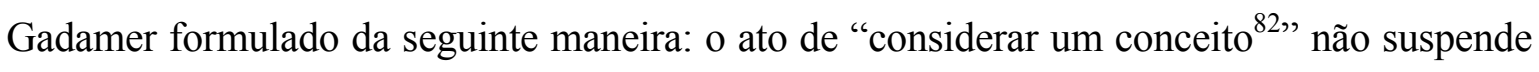
a liberdade da imaginação. Nas palavras de Gadamer (2007a, p. 88) a beleza está em questão “onde a imaginação está em livre concordância com a compreensão, ou seja, onde pode ser

\footnotetext{
${ }^{82}$ Considerados aqui como todos os valores, conceitos e temas.
} 
produtiva". Os conceitos não servem aqui como barreiras que limitem a criação, mas como estímulos para o jogo da imaginação, originando uma unidade compreensiva e produtiva.

A reação do leitor com relação à obra pode ser de admiração e/ou de indignação, sendo que na admiração repousa a promessa de imitar e na indignação a promessa de mudar. É certo que a literatura é uma coisa e a moral é outra bem diferente, sendo que aquela, de modo ético, atua principalmente como um ato de confiança na liberdade dos homens, enquanto que as regras morais se baseiam, justamente, na desconfiança de que os homens não sejam capazes de viver em plena liberdade. Como veremos com maior profundidade no próximo capítulo, aquele que escreve reconhece, pelo próprio fato de se dar ao trabalho de escrever, a liberdade de seus leitores, e aquele que lê, pelo simples fato de abrir o livro, reconhece a liberdade do escritor. Daí decorre que não existe literatura antiética, pois por mais sombrias que sejam as cores com que se pinta o mundo, pinta-se para que homens livres experimentem, diante dele, sua liberdade (SARTRE, 2006, p. 51).

Daí a ambivalência da sociedade em face da literatura, uma vez que ela também veicula noções ou oferece sugestões que a visão convencional gostaria de proscrever. No âmbito da educação escolar, o livro chega a gerar conflitos, porque o seu efeito transcende as normas estabelecidas. De fato, há conflito entre a idéia de uma literatura que eleva e edifica (segundo padrões oficiais) e a sua poderosa força indiscriminada de iniciação na vida, com uma variada complexidade nem sempre desejada pelos educadores. Nas belíssimas palavras de Candido (CANDIDO, 2004, p. 176), "ela não corrompe nem edifica, portanto; mas trazendo livremente em si o que chamamos o bem e o que chamamos o mal, humaniza em sentido profundo porque faz viver”. Essa é uma das formas da experiência que descrevíamos no tópico anterior.

A obra literária sempre expressa algo que diz respeito ao humano, uma vez que o artista, ao formular a representação, não realiza uma cópia, mas atribui uma alma ao representado. Quando cria um personagem caracterizado como humano, contudo, essa expressão é mais direta, porque não é necessário imprimir-lhe um significado obliquamente. A figura humana expressa os valores em seu próprio ser. Além disso, a expressão da ética humana permeia toda a representação artística: quando humana, aquilo que nos fala na representação como conteúdo ético é uno com o ser humano representado; e quando figurativa, a metáfora e a analogia emprestam à figura a expressão do ético do humano. A representação do humano, na arte e na literatura mais explicitamente, expressa as idéias em seu próprio ser, porque o homem é o que é. Mesmo quando se representa uma paisagem, ou 
a natureza morta, está-se expressando os valores humanos, mesmo que obliquamente, porque é colocado o olhar, a sensibilidade e o pensamento do artista sobre eles.

A literatura, como arte representativa que é, passa também pelo crivo da estética. Evidentemente que a composição da obra literária será mais interpeladora quanto maior sua beleza. Mesmo porque ninguém é escritor por ter decidido dizer certas coisas, mas por haver decidido dizê-las de determinado modo. E o estilo, decerto, é em grande medida determinante do valor da escrita. Mas ele deve passar despercebido, sendo que num livro a beleza não explode como em uma tela, mas se esconde, agindo por persuasão, como o charme de uma voz ou de um rosto. Assim, somos solicitados por um encanto que não se vê (SARTRE, 2006, p. 22).

O fato de o escritor buscar a beleza não retira o caráter de gratuidade da obra literária, uma vez que não só a beleza contribui para a elaboração do significado total da obra, como a busca pelo belo não existe em função de uma utilidade; o belo não é buscado por ser útil ou prazeroso. Por outro lado, a apreensão da obra e o arrebatamento e envolvimento do público em seu significado dependerá do juízo do gosto.

O conceito de belo possui uma estreita relação com o conceito de bem. Em primeiro lugar, porque o belo também deve ser escolhido por si mesmo e não por ser útil. $\mathrm{Na}$ filosofia platônica essa relação entre belo e bem é bastante estreita, e ainda mais na filosofia medieval, em que o belo não só é vinculado ao bom, como também integra uma das formas de acesso ao conhecimento do verdadeiro e do divino. A princípio, a base dessa proximidade da idéia do belo com a ordem teleológica do ser encontra sua base no conceito da medida. Para Platão e Aristóteles, a adequação à medida, simetria e proporcionalidade são as condições decisivas do belo, sendo que mesmo a poesia clássica possuía uma métrica rígida, contada em função das sílabas ${ }^{83}$. Na poesia grega muitos nomes emergem, entre eles Homero, Píndaro e Safo (GADAMER, 2007a, pp. 616-620).

Por outro lado, sustentar o belo unicamente sobre o alicerce da medida e da ordem é basear o julgamento estético unicamente na regra do racionalismo, que não é suficiente. Como veremos, o juízo do gosto não depende de um princípio universal ou de uma regra geral a ser seguida. A beleza não é somente simetria, mas a própria aparência que repousa sobre ela.

\footnotetext{
${ }^{83}$ Ao conjunto de sílabas chama-se pé.
} 
A importância dada pela ciência moderna à forma, contudo, não é tão grande. A ciência moderna só se lembrou da valência ontológica autônoma da forma quando chegou aos limites da construtibilidade mecânica ${ }^{84}$, e ainda assim como princípio suplementar, como um caminho mais refinado para se atingir o domínio do ente. A natureza deixa de ser o paradigma da ordem das coisas belas, como era para Platão e passa a ser objeto de domínio e exploração pelo homem. A arte, por seu turno passa a ser vista em separado, como momento de fruição do belo. No entanto, as duas coisas não se misturam, não têm implicações mútuas; a beleza não mais serve de indicação para a ordem teleológica do ser (GADAMER, 2007a, pp. 616-620).

Na leitura de um texto literário, portanto, nos vemos atraídos tanto pela plenitude de sentido e pela vivência que ele proporciona quanto por sua beleza, que ajuda esse sentido a se pronunciar. Por conseguinte, na literatura é onde tanto o belo como os conteúdos inteligíveis podem existir em sua plenitude, podem aparecer: "a luz que faz com que tudo apareça de maneira que seja luminoso e compreensível em si mesmo é a luz da palavra" (GADAMER, 2007a, p. 622).

O belo, nesse sentido, também é uma fonte de entendimento e de conhecimento, ao lado da razão, porque é uma espécie de experiência - autêntica experiência, que amplia o horizonte do que deve ser levado em consideração no entendimento - que se sobressai como um encantamento. Na compreensão que se dá na conjunção da beleza com os conteúdos valorativos, estamos incluídos num acontecer da verdade: somos arrebatados e interpelados. Nesse arrebatamento, é inevitável que o ser próprio do leitor também não entre em jogo. Assim, a invenção livre do escritor é a representação de uma verdade que vincula a ambos: escritor e leitor.

A literatura propicia uma experiência ética por acontecer especificamente no fenômeno da fusão de horizontes. O horizonte de valores trazidos por ela, por meio da experiência que ela é, funde-se com o do leitor, que recria aqueles conceitos livremente e imaginativamente. A partir da literatura, tanto o escritor representa os conceitos e valores de seu contexto de forma a elaborar um crescimento e reflexão crítica desses valores quanto o leitor pode experimentar os conceitos representados por meio de uma recriação desse conteúdo. A interpretação do leitor não somente amplia sua visão de mundo e favorece uma forma de conhecimento do mundo sensível e privilegiada como também

\footnotetext{
${ }^{84}$ Aqui também pode se entender o auge das formas de ordenações, categorização e sistematização.
} 
possibilita o exercício de uma capacidade reflexiva e crítica dos valores a caminho de uma existência autêntica.

Conforme faláramos acerca do sensus communis, ele aparece principalmente nos julgamentos sobre justo e injusto, factível e infactível. Quem possui este juízo está apto a realizar um julgamento de justiça e injustiça tendo em vista uma preocupação com o outro. Portanto, o senso comum é o momento de ser cidadão e ético. O sensus communis, por conseguinte, possui uma estreita ligação com o conceito de juízo. Assim, também o juízo moral e estético não possui o caráter de razão, mas de sensibilidade e gosto (GADAMER, 2007a, pp. 71-78).

Tanto o juízo para a decisão moral quanto o do gosto estético não são processos passíveis de demonstração racional. Dessa forma, perplexos, novamente nos encontramos diante do inefável, em que não há conceitos que possam explicar essa faculdade, assim como os sentidos (GADAMER, 2007a, p. 70). A subsunção do particular ao universal pode ser o modo como o juízo ocorre, mas ele não se limita a isso. Isso porque deve sempre extrapolar a realização individual em seu juízo. Não só deve ser a adequação de uma situação concreta a um todo conceitual e tradicional de forma autêntica e imaginativa quanto deve transbordar as margens do próprio sujeito e projetar-se em direção ao outro. Isso por si só já constitui uma ética que contempla os valores base dos direitos humanos.

Para Kant, contudo, a razão prática nada tem a ver com o senso comum, porque seria apriorística (GADAMER, 2007a, p. 73). Do âmbito que se poderia chamar de sensorial em Kant resta o juízo do gosto estético. Todavia, o gosto tem muita semelhança com o senso comum. O gosto sensível não seria um mero instinto, mas estaria no meio do caminho entre o instinto sensorial e a liberdade espiritual.

O que perfaz a amplitude originária do conceito de gosto é que com ele está designada uma forma própria de conhecimento em vista não de uma resposta correta e única, mas de uma resposta plausível e adequada à situação especial. Todas as decisões éticas exigem gosto e reflexão; isso porque todos os casos concretos são especiais. O juízo do gosto, contudo, está longe de ser a particularização de uma lei universal. O modelo e o padrão detêm, de fato, uma função preferencial, mas não na forma da imitação, mas no seguimento. E a capacidade de realizar esse "seguimento" é própria e pessoal. Evidentemente que aqui o gosto não é a base do juízo ético, que depende em grande medida dos valores que apreendemos como corretos por meio de uma interpretação autêntica da tradição, mas certamente é seu mais importante complemento. Onde o injusto 
conflita com o gosto é onde temos mais segurança de nossas decisões éticas (GADAMER, 2007a, pp. 80-84). Esse processo, como dissemos, não é meramente racional, mas depende incrivelmente da inteligência sensível de descrevíamos.

A literatura, portanto, somente conseguirá tocar verdadeiramente seu leitor quando expressar esse conteúdo ético, ou seja, quando extrapolar o que é meramente agradável aos sentidos. O belo que agrada independentemente de conceituação se fará ainda mais poderoso se atingir significativamente o expectador. Isso porque o juízo acerca da beleza não é mera subsunção, mas exige a aproximação do outro. Somente assim a literatura será capaz de operar o encontro do homem consigo mesmo.

Desse modo, a linguagem da literatura é exigente e interpeladora, e sua única finalidade, se assim podemos chamar, seria nos interpelar e colocar o homem diante de si mesmo e de sua existência moral. Todavia, o significado determinado de uma obra, ao invés de nos vincular a uma verdade determinada ou a um aprendizado que se reduz à "moral da história", abre espaço para o jogo da liberdade lúdica de nossa capacidade de conhecimento. Não há, portanto, coerções regulatórias, sendo que não procuraremos equiparar o conceito representado, ou os valores trazidos, como o que se procurou representar, mas esse "conceito" será ampliado de forma ilimitada, com base tanto na autenticidade quanto no reconhecimento do outro (GADAMER, 2007a, pp. 93-94). 
Capítulo III

EM BuSCA do OUTRO 
Iniciamos com o texto de Lispector (1999, p. 118) do qual foi emprestado o título deste capítulo, que segue assim:

Não é à toa que entendo os que buscam caminho. Como busquei arduamente o meu! E como hoje busco com sofreguidão e aspereza o meu melhor modo de ser, o meu atalho, já que não ouso mais falar em caminho. Eu que tinha querido. O Caminho, com letra maiúscula, hoje me agarro ferozmente à procura de um modo de andar, de um passo certo. Mas o atalho com sombras refrescantes e reflexo de luz entre as árvores, $o$ atalho onde eu seja finalmente eu, isso eu não encontrei. Mas sei de uma coisa: meu caminho não sou eu, é outro, é os outros. Quando eu puder sentir plenamente o outro estarei salva e pensarei: eis o meu porto de chegada.

Hoje, consideramos a escrita e a leitura como direitos do homem - ramificações do direito à educação, à cultura e à autodeterminação dos povos -, e, ao mesmo tempo, como meios de se comunicar com o outro, quase tão naturais e espontâneos quanto a linguagem oral. A partir daí, pretendemos investigar a dimensão da literatura que diz respeito ao seu modo de ser que faz dela uma forma de discurso e de diálogo; como bem se sabe, discurso e diálogo na realidade são duas faces da mesma moeda. Emprestamos aqui uma das descrições da literatura elaborada por Antonio Candido (2006b, p. 147), adequada à sua dimensão social e, portanto, dialógica:

(...) obras e atitudes que exprimem certas relações dos homens entre si, e que, tomadas em conjunto, representam uma socialização dos seus impulsos mais íntimos. Toda obra é pessoal, única e insubstituível, na medida em que brota de uma confidência, um esforço de pensamento, um assomo de intuição, tornando-se uma 'expressão'. A literatura, porém, é coletiva, na medida em que requer uma certa comunhão de meios expressivos (a palavra, a imagem), e mobiliza afinidades profundas que congregam os homens de um lugar e de um momento, para chegar a uma 'comunicação'.

(...) Assim, não há literatura (...) enquanto não houver outros homens aptos a criar ressonância (sem grifos no original).

A literatura, além de ser um vasto laboratório onde experimentamos, com estimativas, avaliações e julgamentos de aprovação e condenação, os caminhos e a ética, também é uma forma de ser com o outro, de compartilhamento do mundo que se dá por meio do reconhecimento, da confiança e de atos de generosidade do escritor e de abertura do leitor, fundamentais à realização do próprio modo de ser literário.

Como se discutiu no segundo capítulo, a linguagem é algo distinto e mais abrangente do que os signos são. Heidegger dá um tratamento diferenciado à linguagem ou 
ao discurso e ao signo, uma vez que a linguagem não consiste em uma ferramenta para comunicação ou descrição, mas sim em um meio expressivo por meio do qual compartilhamos o mundo com o outro. Evidentemente que os seres humanos essencialmente já compartilham o mundo entre si, o que se manifesta no mútuo entendimento que em geral é possível entre duas pessoas ${ }^{85}$. O que é compartilhado na literatura, portanto, é um ser com relação ao mundo, um horizonte, expresso no texto literário, para a construção de um ver em comum. A arte de escrever deve conduzir o leitor a pensar o pensado, de forma a estimular os pensamentos do leitor produtivamente, não no sentido de demonstrar-lhe algo ou argumentar, mas de um acenar que abre os olhos: uma única passagem já pode conter toda a transparência necessária para nossa compreensão (HEIDEGGER, 2008c, p. 53).

${ }^{85}$ Quando o mútuo entendimento não é possível, isso significa que existe um vício na relação entre as duas pessoas, que deveria ser de compartilhamento do mundo. 


\section{A literatura como discurso}

Como dissemos, do ponto de vista do escritor, o discurso é expressão mais ou menos autêntica de sua existência. Além disso, o discurso constitui a ação política por excelência, dando sentido às ações dos homens, inserindo-os no espaço público e no presente. A dimensão política do discurso foi amplamente explorada por Arendt, que solidificou, também, a dimensão ética do pensamento de Heidegger. Seguiremos, assim, seus passos para entender como a literatura é discurso ${ }^{86}$ a ser lançado no espaço político livre.

Resumidamente, tendo em vista que os sistemas de proteção internacional dos direitos humanos têm embasamento e/ou conotação políticos, propõe-se estabelecer uma ligação entre a literatura e a política. O ponto que proporciona essa relação seria o conceito de discurso tendo em vista a teoria da ação e do discurso de Arendt e seu conceito de política. Assim, a partir da obra A condição humana, é possível perceber que a criação e atuação da literatura, conforme descritas por Antonio Candido, contemplam alguns conceitos da autora dentro do âmbito da denominada vita activa, enquanto trabalho ${ }^{87}$ ou ação política, ou como ambos.

Conforme já frisamos, o totalitarismo (nazista e stalinista) configurou-se como um advento sem precedentes, não havendo categorias para classificá-lo. A partir dessa indefinição, a tradição política teve de ser revista e ter seus conceitos resgatados. Esse foi o papel da teoria de Arendt e, nesse sentido, percebe-se que ela utiliza definições que divergem bastante do que se procurou chamar de política ao longo de toda a modernidade. Segundo a autora, política é a solução que se apresenta para esse impasse, uma vez que ela é fonte do inesperado e em seu âmbito poderiam operar-se verdadeiros milagres. A ação política, nesse sentido, seria o instrumento para a atuação na esfera política. Existem algumas instituições e leis que asseguram a existência da esfera política imbuída de liberdade, e que asseguram a igualdade e a pluralidade desse espaço. Assim, o poder apenas poderia ser gerado por agentes políticos que agem com um único sentido: a liberdade (LAFER, 2006).

\footnotetext{
${ }^{86} \mathrm{O}$ discurso é o que supera o conceito, o enunciado puro e simples, sendo que as palavras individuais somente alcançam o significado e sua relativa univocidade na unidade do discurso e no diálogo. Assim também é através do discurso que o verdadeiro conhecimento e entendimento do mundo podem ser compartilhados.

${ }^{87} \mathrm{O}$ trabalho será tratado no capítulo IV.
} 
Arendt é inspirada pela polis grega em seu tratamento do que seria o espaço político em que habitam e agem os homens. A interpretação de Heidegger sobre a polis grega em Parmênides (2008), por sua vez, é bastante adequada à visão de Hannah Arendt; valendo, portanto, discorrer brevemente sobre aquela. A relação entre a res publica romana e a polis grega é a mesma que entre a essência moderna da verdade, a rectitudo romana, e a aletheia grega. Isso porque a essência da polis grega se funda na essência da aletheia.

A polis seria a instância na qual a humanidade teria o seu centro no ser. Seria, deste modo, o pólo ao redor do qual todos os entes se deixariam, no todo, descobrir e encobrir, inclusive, e principalmente, o ser dos homens: seria o lugar, a morada histórica, do desencobrimento do ser dos entes como um todo. Assim, é na polis, que inspira o espaço público, político, de Hannah Arendt, que os homens se revelariam, revelariam o seu ser por meio da palavra, do discurso.

Desse modo, a política para Arendt é aparência, representação, sendo que o conflito não é parte integrante desse espaço, mas o entendimento mútuo e o diálogo. O interesse, dessa forma, pode influenciar a ação do agente, mas não determiná-la. A opinião, revelada por meio do discurso, traduziria o que o agente pensa, como vê e se comporta em relação ao mundo, de forma livre e sem coerção, revelando também a singularidade e autenticidade desse agente. Além disso, embora sempre tenha em vista, em alguma medida, o homem universal, o discurso como ação política coloca em evidência uma dimensão da temporalidade que coloca em questão os muros da eternidade e do passado que sustentam costumes, ideologias e tradições: o presente.

Assim, aquele que discursa está em situação na linguagem, investido pelas palavras, que são o prolongamento de seus sentidos, manipulando as palavras a partir de dentro, sentindo-as como sente seu corpo. Aqui, o discurso constitui a ação política por excelência: a fala é um dado momento particular da ação e não se compreende fora dela. A partir da fala podemos modificar o mundo, uma vez que um ente, quando nomeado, não é completamente o mesmo. Da mesma forma, quando descrevemos uma situação, nós a desvendamos a nós mesmos e aos outros; por meio do discurso eu desvelo a situação por meu próprio projeto de transformá-la e, a partir daí, já tem início a ação de transformação. Nas palavras de Sartre (2006, p. 20): “(...) a cada palavra que digo, engajo-me um pouco mais no mundo e, ao mesmo tempo, passo a emergir dele um pouco mais, já que o ultrapasso na direção do porvir." 
Vale dizer que a literatura nasce da falta. Primeiramente, nasce do não-ser, da falta do que o mundo existente que chamamos de real não é. A frustração de nossas expectativas desde muito cedo na existência já nos faz perceber essa falta. Trata-se de uma percepção que somente acentua-se com o passar do tempo: a percepção de que o real não basta. Mesmo porque, à medida que crescemos, passamos a fazer especulações racionais acerca de como o mundo deveria ser e não é. A falta é um dos reflexos da finitude e contingência humana e se abate sobre todos os homens em todos os tempos. Diante dessa percepção e da angústia gerada existem diversas formas de reagir, dentre as quais figura a imaginação e o modo artístico de exercê-la, que consiste em sua exteriorização para que outras pessoas possam compartilhar dela (PERRONE-MOISÉS, L., 2006a).

A literatura, assim, é uma das práticas de reconstrução do mundo pelas palavras, uma das formas de refazer o real com a ajuda da imaginação. Todavia, como bem sabemos, nem todas as obras compensam positivamente o não-ser do mundo em que vivemos, trazendo uma visão de um mundo mais belo e prazeroso que o real; algumas obras mostram um mundo ainda mais terrível do que esse. Nesses casos, evidenciam-se ainda mais a falta e a fragilidade do homem frente ao mundo circundante. Em todo caso, a literatura aponta sempre para o que falta no mundo e em nós, no sentido de uma superação dessa falta. Ou permite vislumbrar um mundo melhor, ou, acentuando o que está mal, torna a vida tão insuportável que força uma mudança, um novo projeto de futuro: "trágica ou epifânica, negativa ou positiva, ela está sempre dizendo que o real não satisfaz" (PERRONE-MOISÉS, L., 2006a, p. 104).

A angústia e a infelicidade sofrem uma transformação com a literatura, transformação esta que compensa a falta pelo seu próprio modo de ser. Primeiramente, a própria linguagem é insuficiente para retratar o real, sendo que é imprescindível que façamos uma escolha de como vamos representar o real nos valendo de palavras. Sempre, portanto, a literatura propõe uma reinvenção do real. Aí repousam infinitas possibilidades de reinvenção que podem ser escolhidas pelo escritor, ou melhor, que expressam sua própria visão de mundo e sua forma de estar no mundo. Por ser linguagem a literatura nunca pode ser plenamente realista (PERRONE-MOISÉS, L., 2006a).

A verdade trazida pela literatura não é possível de se ver a olho nu, no entanto, quando possibilitada de ser vista pela literatura e sua ordenação formal, nos obriga a reformular o real. Veremos que a simples denúncia do que vai mal no mundo não se compara com o efeito conseguido pelo trabalho da forma da literatura e pelo modo hermenêutico da leitura. Assim, inventar e apresentar o inexistente é só aparentemente uma 
ação alienante do real, pois, quando esse mundo inventado se ergue, ele é um poderoso rival daquilo que aceitávamos como real (PERRONE-MOISÉS, L., 2006a, pp. 103-107).

O homem que escolhe o discurso como modo de agir, escolhe a ação por desencobrimento: se a sociedade se vê e se vê vista, isso enseja um questionamento dos valores estabelecidos, uma vez que o escritor apresenta a imagem da sociedade e a intima a assumi-la ou a transformar-se, mesmo porque a fantasia refere-se constantemente a uma realidade. Admitimos, portanto, que a obra literária significa um tipo de elaboração das sugestões do eu e do mundo e que possui autonomia de significado; "mas que esta autonomia não a desliga das suas fontes de inspiração no real, nem anula sua capacidade de atuar sobre ele" (CANDIDO, 2002, p. 83). É nesse sentido que a literatura pode ser revolucionária, mantendo vida a utopia que muito embora figure no não-ser, é possível, verossímil, não como o imaginário impossível, mas como o imaginável possível (PERRONE-MOISÉS, L., 2006a, p. 108).

Candido (2004, pp. 184-185) menciona o exemplo de Émile Zola (1840-1902), que conseguiu fazer uma verdadeira epopéia do povo oprimido, retratando as conseqüências da miséria, da promiscuidade, da espoliação econômica, o que fez dele um inspirador de atitudes e idéias políticas. Sendo ele próprio inicialmente apolítico, esta conseqüência de sua obra nada tem a ver com seus interesses. Contudo, a força política latente dos seus textos acabou por levá-lo à ação através do discurso. Isso se deu quando ele assumiu posição contra a condenação injusta do capitão Alfred Dreyfus (1859-1935), cujo processo entrou em fase de revisão, terminada pela absolvição final, graças a seu panfleto J'accuse (1898). Como conseqüência de seu manifesto, Zola foi julgado e condenado à prisão por ofensa ao Exército. Um de seus romances mais famosos é o Germinal, em que descreve minuciosamente as condições de vida subumanas de uma comunidade de trabalhadores de uma mina de carvão na França, que culminam em uma greve geral, que é, contudo, violentamente reprimida. Enfim, trata-se de um autor identificado com a visão de mundo de sua obra, que opta por compartilhá-la com a sociedade, reunindo a produção literária à militância política.

No Brasil, a literatura empenhada em uma tarefa política ganhou força real, sobretudo no decênio de 1930, quando o romance de tonalidade social passou da denúncia retórica, ou da mera descrição, a uma crítica que surge do âmago do escritor, que passa a discursar para um público cada vez mais amplo e menos elitizado. Graciliano Ramos (1892-1953) é um dos escritores que compuseram o batalhão de escritores brasileiros empenhados em expor e denunciar a miséria, a exploração econômica e a marginalização. 
Figuram entre suas obras: Vidas Secas (1938) e Memórias do Cárcere (1953). Filiado ao Partido Comunista Brasileiro (PCB), sua atuação política ocorreu especialmente através de suas obras, discursos que passaram a ecoar no espaço político brasileiro e até hoje o compõem. Graciliano reafirma o vínculo da literatura com a vida, tendo em vista que a imaginação, as experiências e sua identidade confundem-se em sua obra.

Graciliano procura, por meio de sua escrita pessoal, transformar as diretrizes e os valores que o processo de modernização brasileira começava a implantar no país nas primeiras décadas do século XX. Regiões sombrias da nova ordem estabelecida atingem o primeiro plano do texto, que torna visível a violência contra os excluídos, então revelados em sua alteridade e desolação. Por meio de sua memória, o artista libertou-se do encarceramento que o impedia de participar do presente.

De qualquer forma, a função do discurso político, em especial literário, é quebrar o equilíbrio que a ignorância proporciona, introduzindo um novo olhar. Assim, a literatura está sempre jogando com o ser e com o não ser, com a negatividade; todavia, o escritor deve ter cautela para não transformar sua obra em uma negação absoluta e abstrata, sob o risco de a sociedade passar a desqualificá-la como "mera literatura", não mais a levando a sério como projeto de transformação social.

Da ação discursiva decorre, ainda, uma potencial imprevisibilidade, pois o discurso na esfera pública deve ocorrer livre de qualquer elemento que determine a finalidade da ação, uma vez que a ação política seria desinteressada por princípio. Assim, a causa defendida nos discursos deve ser sempre sua finalidade aparente, uma vez que a finalidade profunda deve ser entregar-se. A literatura é o ser mais profundo do escritor e seu horizonte, inefável, muitas vezes ilógico, que se entrega de um modo articulado e generoso.

O discurso do escritor pode ser extraído da vida que as pessoas levam no dia-a-dia e que suportam sem encontrar palavras para articular e, portanto, compreender seus sofrimentos; porém, deve ser sempre seu. O escritor retoma essa situação existencial de forma reflexiva e crítica, constituindo o seu discurso, mas representativo de toda uma classe, um país, um tempo. Todos que não vivenciaram essa mesma situação existencial representam o outro com quem a obra vai procurar dialogar ${ }^{88} 89$.

\footnotetext{
${ }^{88}$ Nesse ponto, quando se trata do outro na obra, também é preciso realizar um esforço de compreensão de um contexto diferente, no intuito de atingir o outro, comprometê-lo. Assim, nesse caso, cada palavra remete a dois contextos (dualidade do público): do próprio escritor e do outro (público virtual).

${ }^{89}$ No movimento de idéias que ocorreu tanto na Europa quanto no Brasil entre 1830 e 1848 , alguns autores das zonas marginais da burguesia tentam criar a dualidade do público, imaginando um público virtual, que chamam de povo. Não há dúvida de que a entrada do pobre no temário do romance, no tempo do Romantismo, e o fato de ser tratado nele com a devida dignidade, tenha sido um momento relevante dos direitos humanos por meio da
} 
Abraçar a imprevisibilidade e a espontaneidade, negando o caráter instrumental da política, implica afastar soluções autoritárias e totalitárias, o que faz muito sentido no contexto em que a teoria de Arendt foi pensada. Mas se pode concluir que, independentemente de qualquer finalidade, o homem que discursa decide desvendar o mundo para os outros homens, a fim de que estes assumam, em relação ao que está sendo desvendado, responsabilidade. Assim, ninguém poderá ignorar o mundo e considerar-se inocente diante dele, não podendo abster-se da escolha ética em relação ao mundo (LAFER, 2006).

Expandindo um pouco a classificação realizada por Arendt: da literatura como arte e produto do trabalho humano; pretendemos discutir se os conceitos de ação e de discurso comportam também a produção literária como ação política.

O palco teatral é uma instituição política de natureza única, uma vez que carrega a imprevisibilidade e a espontaneidade da ação política. Cada execução da obra de dramaturgia é um acontecimento que deixa transparecer o que há em jogo, além de ninguém saber de antemão qual será o impacto da obra no espectador. Como cada interpretação da obra dramatúrgica é única, essa é de natureza ocasional, assim como a ação política. Porém, essa ocasionalidade não significa que a obra literária original esteja sendo adulterada ou erroneamente interpretada. Muito pelo contrário, é a cada interpretação é que ela se realiza por completo (GADAMER, 2007a, p. 209). Além disso, a efeméride que se concretiza na interpretação da obra teatral não obsta a sua perenidade, que se constitui justamente pela capacidade de aproveitar, a cada nova interpretação, a oportunidade de renovar-se.

A poesia, por seu turno, que possui uma estrutura especulativa intrínseca, trata com excelência de assuntos que usualmente têm lugar no falar cotidiano. Evidentemente que a enunciação poética não o faz como faria um relatório ou um discurso no palanque, mas de uma forma misteriosa o todo da conversação se faz presente ali. Assim como na fala cotidiana e no discurso, as palavras poéticas ${ }^{90}$ são especulativas, estimulando o interlocutor

literatura: os escritores criaram em torno do povo uma aura mística, porém, embora o amassem, não o conheciam, sequer emanavam dele. Victor Hugo, embora tenha tido a rara felicidade de penetrar em todas as camadas, é filho de um general do Império; Castro Alves, apesar de conhecido como o poeta dos escravos, nasceu na fazenda Cabaceiras e era filho do Dr. Antônio José Alves e D. Clélia Brasília da Silva Castro, tendo concluído os estudos na Faculdade de Direito de São Paulo. Todavia, outros escritores que se valem da mesma temática, que escrevem para esse mesmo público virtual, não foram tão felizes em atingi-lo, como por exemplo, Bernardo Guimarães com sua obra A escrava Isaura.

${ }_{90}$ Quando falamos em enunciação poética, não nos referimos em absoluto ao enunciado, como tal, que um personagem fala na poesia. Referimo-nos ao enunciado que é a própria poesia enquanto palavra poética (GADAMER, 2007, p. 606). 
a questionar e a buscar o sentido no que não foi dito, mas que pode desvelar-se para o interlocutor a depender de seu comportamento, sua audição, especulativa, aberta e dialógica $^{91}$.

O que distingue a poesia é o fato de estar sempre no horizonte do indizível, ou do simplesmente não dito, como vimos no capítulo anterior. Sempre é a totalidade o que queremos compreender ou dizer, mas nunca somos capazes de dizê-la. Dessa maneira, o poema é sempre um diálogo, porque mantém sempre a conversação com ele mesmo. $\mathrm{O}$ poema não cai do céu nem ao poeta e nem ao leitor, não os é dado de bandeja. É como um diálogo, e nossa relação de leitura com o poema deve produzir um sentido participando nele.

A literatura em suas diversas formas cumpriria, portanto, o papel de discurso, revelando o autor da obra, o herói da História maior, uma vez que a arte pressupõe um indivíduo que assuma a iniciativa da obra. Conforme o que é explicado no segundo capítulo, a literatura é uma representação do mundo real que opera um crescimento neste, a partir de algo de particular do autor e de sua visão de mundo. Partimos do pressuposto de que o discurso pode extrapolar a fala, assim como a peça de teatro extrapola a atuação dos atores e abarca também os textos de dramaturgia. Nesse sentido, o discurso poderia ser produzido também na forma escrita e, apesar de dirigido a uma ou mais pessoas, disseminar-se em um público de leitores indetermináveis a princípio. É natural, portanto que se reflita a respeito do papel da literatura enquanto reveladora dos homens e agentes políticos e de seu discurso, quer ele se pretenda completamente ficcional, quer se pretenda social, portador de uma ideologia.

Segundo Sartre, a literatura se distingue das outras artes enquanto discurso político porque de fato consegue expressar discursivamente uma determinada visão de mundo, um horizonte compreensivo. Quando existimos, em geral já compartilhamos o mundo com o outro; porém, o que compartilhamos no discurso, mais particularmente, é nosso ser com relação ao que está sendo apontado, para que o nosso interlocutor possa ver o mundo por meio de uma fusão de horizontes. O exemplo utilizado por Sartre (2006, p. 12) para ilustrar no caso o comportamento político que se pode ser expresso em relação ao mundo é o que segue: "o escritor pode dirigir o leitor e, se descreve um casebre, mostrar nele o símbolo

\footnotetext{
${ }^{91}$ Assim, pouco a pouco começa nosso diálogo com o poema e isso exige tempo, uma vez que não se pode entender um poema se o lermos uma única vez. Quem pensa assim nunca experimentou um poema. O poema nos convida a uma audição abrangente e a um intercâmbio de palavras no qual se consuma a compreensão. $\mathrm{O}$ poema, porém, não dialoga somente com o leitor, sendo em si mesmo um diálogo, um auto-diálogo no jogo do dito com o não dito, que é um convite ao perguntar e à conciliação na produção de sentido (GADAMER, 1993, p. 150).
} 
das injustiças sociais, provocar nossa indignação. Já o pintor é mudo: ele nos apresenta um casebre, só isso; você pode ver nele o que quiser."

Para Sartre, é possível que a indignação, a cólera e a caridade possam produzir outras artes que não a literatura, mas nelas "ficarão atoladas na mesma forma; perderão o seu significado, restarão apenas coisas habitadas por uma alma obscura" (SARTRE, 2006, p. 12), não serão passadas adiante, não adquirirão uma existência autônoma como a da literatura. Assim, é na escrita que a linguagem atinge sua verdadeira independência ${ }^{92}$, uma vez que o discurso adquire, no texto, completa autonomia. Não é por acaso que o conceito da filologia, do amor aos discursos, com o aparecimento da cultura literária se transformou na arte oni-abrangente da leitura, perdendo sua relação originária com o falar e argumentar. Nas belas palavras de Gadamer (2007a, p. 506): “é só a tradição escrita que pode desligarse da mera persistência de resíduos de uma vida passada, a partir dos quais é possível à existência (dasein) remontar a outra existência completando-a".

A partir do momento que o escritor opta por colocar sua visão do mundo articulada em um texto escrito, ele pretende algo mais do que realizar algumas anotações no papel que registrem de alguma forma sua intuição; forma esta que será entendida sem dúvida por ele próprio, mas não necessariamente pelos outros. Na medida em que ele articula as palavras em frases, com alguma preocupação pela clareza, é preciso que ocorra uma decisão estranha àquela intuição: a decisão de comunicar aos outros o horizonte da sua compreensão (SARTRE, 2006, pp. 19-20).

A escrita carrega, portanto, a vontade de preservação do discurso, de disseminação da mensagem no tempo e no espaço; sendo determinante o fato de que há uma vontade de sobrevivência que criou sua própria forma de conservação, que chamamos de literatura. Ao final da época histórica do pensar grego originário, isto é, em Platão, a fala plena do pensar de realiza na forma do diálogo. Era como se antes do fim do pensar grego originário, este quisesse atestar a dignidade essencial da palavra quando o homem está em uma relação imediata com a aletheia. Platão permite que a Sócrates interrompam seus interlocutores e enquanto Sócrates segue o logos do pensamento e esta empenhado no diálogo com o outro,

\footnotetext{
${ }^{92}$ Vale ressaltar neste ponto que o discurso literário não é distinto somente por vir à fala por meio da escrita, mas por todo o seu modo de ser peculiar, que traz à tona a verdade discursiva e poética, conforme discutido no segundo capítulo. Muitas vezes a forma de esse desvelamento ocorrer é a emoção provocada pela obra, o que não torna o discurso literário menos legítimo e verdadeiro. A tendência literária marcada pelo nacionalismo brasileiro, por exemplo, produziu obras com tom verbal, que tendiam a despertar a emoção. O escritor brasileiro conservou sempre algo daquela vocação patriótico-sentimental, que veio a afetar todas as demais artes posteriores no Brasil. Sem mencionar um exemplo tão distante no tempo, quanto atual: as tragédias, que atuavam em momentos catárticos, tornando possível a mais profunda compreensão e envolvimento com a obra.
} 
aqueles que o acompanham ofereçam um suporte único para que nada se confunda ou se perca. Assim como qualquer outro falante, a única coisa buscada pelo escritor e pelo poeta é que o acompanhem.

Platão reconhece em Fedro a prioridade da palavra falada sobre a escrita; contudo, havemos de admitir que não teríamos qualquer acesso aos diálogos platônicos caso estes não tivessem sido escritos, caso a arte de formular e evocar, com recursos literários, uma realidade viva (HEIDEGGER, 2008c, p. 131), sem contar que a própria obra escrita, introduz o leitor como um interlocutor em um diálogo literário. É descabido pretender que a compreensão acompanhante a que aspira toda escrita e sua interpretação seja algo assim como uma construção de sentido que reside supostamente no texto. Não se trata, portanto, da reconstrução de um sentido existente, muito menos de encontrar aquilo que o escritor havia pensado. Trata-se de participar no íntimo diálogo com a linguagem (GADAMER, 1993, p. 153).

Graças à escrita, o discurso adquire uma existência autônoma, de modo que ela o eleva aos olhos de todos, para uma esfera de sentido da qual pode participar qualquer leitor, independentemente de sua localização espaço-temporal (GADAMER, 2007a, pp. 506-507). Entretanto, por mais que cobice os louros eternos, o escritor fala a seus contemporâneos, a seus compatriotas, a seus irmãos de raça ou de classe, ou então ao outro que deseja atingir, comprometer. O escritor não fala ao leitor universal, porque não estaria atingindo ninguém ${ }^{93}$, dirigindo-se a nenhum valor. Ele discursa ao espaço político do qual participa, ao mundo em que vive, embora saiba que sua literatura poderá extrapolar essa situação existencial, ter sua própria existência ${ }^{94}$. O escritor está em situação como todos os outros homens. Por esse mesmo motivo, não é concebível que se possa exercer a liberdade de manifestação, escrevendo para um público mais amplo do que a coletividade dos especialistas e, ao mesmo tempo, limitar a literatura a conteúdos eternos e intangíveis.

\footnotetext{
${ }^{93} \mathrm{Na}$ realidade, o escritor sabe que fala a liberdades mascaradas, atoladas. A sua própria autenticidade não é assim tão pura e também para limpá-la ele escreve. Seria perigosamente fácil tratar de valores universais e eternos. Todavia, não seriam valores humanos, compreendidos na perspectiva da finitude humana, na complexidade que ela representa. Os obstáculos e limites de cada tempo e lugar dão feição à liberdade e ao reconhecimento. A superação daquela situação existencial é que delineia sua aparência, promove seu desvelamento. A liberdade não é, ela se conquista numa situação existencial: cada livro propõe uma libertação concreta a partir de uma alienação particular. Nas próprias palavras do escritor Graciliano Ramos (1953): "liberdade completa ninguém desfruta: começamos oprimidos pela sintaxe e acabamos às voltas com a delegacia de ordem política e social, mas, nos estreitos limites a que nos coagem a gramática e a lei, ainda nos podemos mexer". Por isso, o satanismo ultra-romântico da Faculdade de Direito do Largo São Francisco no século XIX é tão emancipador e engajado quanto a poesia abolicionista de Castro Alves. Ambos são apelos à liberdade nos contextos onde surgiram e até hoje: quer seja a libertação da imaginação ou dos escravos.

${ }_{94}$ Não que ele não pretenda atingir, através destes leitores, todos os homens: a universalidade do gênero humano está no horizonte do grupo concreto e histórico dos seus leitores, assim como a liberdade eterna se deixa entrever no horizonte da libertação concreta.
} 
Evidentemente que o grau de dependência de uma obra do contexto social para o qual foi criada pode ser maior ou menor, a depender da função social exercida pela obra naquele contexto. Assim, algumas obras, especialmente as de tradição oral, dependem da pessoa que as interpreta, do ato de interpretar e, sobretudo, da situação de vida e convivência, em função da qual foram elaboradas e são executadas. As obras de função social de caráter ocasional e restrito são feitas para serem incorporadas imediatamente à experiência do grupo, à sua visão de mundo e da sociedade. Assim, pouco significam separadas da circunstância, uma vez que possuem uma autonomia menor. Talvez seja necessária uma maior elasticidade na elaboração, que é conferida à obra pela composição artística sobre a palavra escrita, e em sua interpretação, para que o texto adquira autonomia e guarde em diversos contextos algum significado e o impacto, adquirindo assim uma função total (CANDIDO, 2006b, pp. 60-61).

Também as técnicas de comunicação de determinada época influem na possibilidade de determinado discurso atingir o público prefigurado e o indeterminado. No âmbito literário, essas técnicas podem ser imateriais ${ }^{95}$, como também associarem-se a objetos materiais, como o livro, um instrumento musical, o rádio ou a tela. A poesia é um exemplo claro de como técnicas de comunicação são utilizadas na literatura: o refrão, a recapitulação, a medida do verso, estão ligados ao fato de a poesia haver se originado em contextos onde não havia a escrita, devendo-se atender às exigências de audição e memorização (CANDIDO, 2006b, p. 42). Todavia, com o triunfo da escrita ${ }^{96}$ como meio de comunicação, o panorama necessariamente se transforma. A poesia, por exemplo, deixa de depender exclusivamente da audição e pode concentrar-se em valores intelectuais, bem como dirigir-se preferencialmente à vista. Nas palavras de Candido (2006b, p. 43), "a poesia pura do nosso tempo esqueceu o auditor e visa principalmente a um leitor atento e reflexivo, capaz de viver no silêncio e na meditação o sentido do seu canto mudo."

\footnotetext{
${ }^{95}$ Como o estribilho das canções.

${ }^{96}$ A esse respeito, Heidegger (2008c, p. 119 e 120) observa uma transformação no modo de o homem agir no mundo ao longo da "história" dos modos da escrita. Segundo ele, o homem age através da sua mão, tendo em vista ser a mão, em conjunto com a palavra, a distinção essencial do homem. Por intermédio da mão é que se dá o encobrimento e o desencobrimento, onde ela é linguagem. Assim, nem mesmo a mão em desespero é equivalente a uma garra; ela é também linguagem. A palavra, portanto, é o âmbito essencial da mão. A palavra que se deixa cunhar e assim se mostra ao olhar é a palavra escrita.

Para Heidegger, contudo, a transformação da escrita à mão em escrita por meio da máquina é uma das mais importantes razões da crescente degradação da palavra, visto que a máquina de escrever, e modernamente o computador, arranca a escrita do âmbito essencial da mão: o que antes ela uma palavra desenhada e estruturada, agora é datilografada, digitada. Assim, na escrita à máquina, todos os homens pareceriam iguais. Deste modo, a tecnologia influi na comunicação tanto na escrita quanto na recepção do texto, para muito além da transposição da oralidade para a escrita, mas também no âmbito das próprias técnicas de escrita.
} 
É dito por Gadamer (1993, pp. 145-149) que é muito difícil encontrar o tom para a declamação de um poema a ser transportado corretamente ao ouvido. Ele entende que, na verdade, esse tom já deve estar no ouvido de todos, para quem o recita poder, de certo modo, dizer em voz alta o que todos ouvem interiormente, tendo em vista que o poema é um estribilho da alma, e, como o estribilho, fala em coro. Como uma canção festiva que todos cantam em coro e na qual todos são a mesma alma.

O poema, tanto quando escrito como quando inscrito na memória a partir do texto exato que se deve ter previamente no ouvido, adquire existência como literatura, ao passo que o diálogo vive a favor do instante. Contudo, em ambos se consuma o mesmo fenômeno: a produção de sentido. Todavia, como visto, não se trata de um sentido que parte supostamente do poema, mas de um encontro, um acompanhamento por parte do leitor. Este somente busca sinais que indiquem para onde deve dirigir seu olhar. Por isso mesmo, a única interpretação correta de um poema é aquela que desaparece toda vez que voltamos a abordá-lo. Uma interpretação que se mantém presente em toda leitura do poema ou em cada vez que o recitamos é superficial e estranha (GADAMER, 1993, pp. 153-154).

Por todo o exposto, o discurso silencioso da literatura mantém sua capacidade de surpreender e impactar, trazendo algo novo ao mundo, porque a experiência hermenêutica do compreender também é um acontecer espontâneo e imprevisível. Quem compreende pode ser surpreendido ao ter os seus preconceitos negados pela proposta de sentido do texto; no entanto, para que a surpresa seja autêntica, assim como a novidade do texto a cada leitura, é necessário que o leitor exercite a escuta, e, posteriormente, aproprie-se do sentido do texto.

\subsection{A Tragédia}

Talvez o exemplo mais significativo do discurso político no sentido aqui proposto sejam as tragédias ${ }^{97}$. O conteúdo específico, bem como o significado geral da ação, pode tomar forma de diversos modos, todavia, o caráter de revelação da ação e do discurso é

${ }^{97}$ A tragédia simboliza o sacrifício humano vicarial praticado pelos povos "primitivos", posteriormente substituído pelo sacrifício dos animais, do bode. Na medida em que o sacrifício vicarial é substituído pela simbologia trágica, o homem grego se humaniza. 
expresso com excelência por intermédio da reprodução ou mimesis. Esta tem lugar em todas as artes, mas, segundo Aristóteles, é realmente adequada ao drama, à representação teatral (ARENDT, 2001). Essa seria a razão pela qual o teatro é a arte política por excelência (ARENDT, 2001). Além disso, a estrutura cênica em semicírculo, que ao invés de ser composta apenas por um palco, apresentava um espaço para ação onde ficaram os atores e outro claramente delimitado para o coro ou orquestra, estabelecia uma relação entre o coro ${ }^{98}$ e ação. Todavia, trata-se da ação enquanto práxis, ação política e pública, e não como poiesis, como a descoberta do indivíduo. Aliás, esse é o conflito base da tragédia: como os cidadãos podem exercer a práxis e não serem livres?

As tragédias gregas eram também discursos que ecoavam no espaço público da polis. Devemos compreender a polis, porém, não como "Cidade-Estado", tendo em vista que esta é uma concepção moderna, adulterada. Ela é, antes, a abóbada histórica em que se reúne a humanidade, a unidade de cada coisa que, desvelada, advém ao homem. Todavia, não devemos dar uma visão parcial da aletheia; vale mostrar que ela possui uma essência conflitante, que aparece também na forma da dissimulação, da obliteração e do encobrimento, ou seja, o não-ser na multiplicidade de sua essência contrária, que empresta à polis o seu caráter cruel e atroz. Desse modo, essa revelação e encobrimento do ser ocorrem com base na palavra e, muito especialmente, são retratados no âmbito da tragédia. A máscara trágica, que a torna tão diferente das artes dramáticas posteriores, é um símbolo da dualidade da aletheia que vigorava na polis.

A ascensão e queda do homem na sua histórica abóbada essencial são mostradas pela tragédia, pois provêm desse singular enraizamento na essência conflitante da aletheia. A forma como os gregos habitavam o mundo e expressavam-se literariamente e poeticamente nesse âmbito originário da política era a tragédia, fazendo uso da linguagem mitológica ${ }^{99}$ para expressar o encobrimento e desencobrimento do ser, discutindo a problemática da luta histórica do homem contra seu destino. O verdadeiro sentido da tragédia é este.

O jogo do encobrimento e desencobrimento dos entes se dá no âmbito da polis por meio da ação e do discurso humanos, sendo que a tragédia procura imitar a ação, delineando os limites da liberdade. A tragédia grega trata essencialmente da liberdade humana contra o destino guiado pelos daimons. Édipo por exemplo, só desempenha um ato de liberdade em toda a peça Oedipus tiranos, que é um gesto de sofrimento atroz: o ato de cegar-se.

\footnotetext{
${ }^{98} \mathrm{O}$ coro é composto de cidadãos livres, que têm o dom da palavra e do discurso.

${ }^{99}$ Modo de fala reflexiva que discursa no interior da aletheia, tocada e circundada por ela.
} 
Vale ressaltar, contudo, que os autores trágicos divergiam entre si acerca da possibilidade de os homens que desafiavam as determinações divinas ${ }^{100}$ obterem ou não êxito em suas ações. Porém, todos tinham em comum uma visão da realidade atenta ao ser, originária e essencial. A essência da tragédia, portanto, é o homem político em plena ação, todavia não na ação política moderna, mas sim na originária, que se aproxima do entendimento de Arendt.

Explica-se, assim, como a função social e política das obras do homem grego originário se dá com base no ser. Os verdadeiros representantes da paidéia grega não são os artistas mudos - escultores, pintores, arquitetos -, mas os poetas e os músicos, os filósofos, os retóricos e os oradores. No pensamento grego, o legislador, por exemplo, encontra-se muito mais próximo do poeta do que do artista plástico. A palavra e o som, o ritmo e a harmonia, na medida em que atuam pela palavra, pelo som ou por ambos, são as forças formadoras da alma. O epos heróico, do qual dimana a força para o resto da poesia, lança as raízes no mais profundo do solo social e político (JAEGER, 1986, pp. 12-13).

Na poesia pós-homérica, as formas poéticas começam a separar-se do mito que, ou é completamente abandonado ou é introduzido na forma de exemplos isolados no decurso do pensamento alheio ao mito. Por isso, grande parte dessa poesia consiste em preceitos e avisos de ordem geral; o resto é constituído por reflexões mais ou menos filosóficas. Assim, a tragédia vem resgatar na poesia grega a linguagem mitológica autêntica. A tragédia ática vive um século inteiro de hegemonia, coincidente com o crescimento, auge e decadência da polis como a concebemos (JAEGER, 1986, pp. 197-218).

Ao longo do século da tragédia ática, existe uma evolução no sentido da exposição ao público das justificativas das ações dos heróis trágicos, preocupação esta que evolui juntamente com a retórica. Nos dramas de Eurípedes, por exemplo, há uma maior exposição das próprias razões, comparativamente aos gramas de Ésquilo. Evidentemente que essa preocupação é vinculada à exposição da individualidade do homem grego que começava a se delinear. Dessa maneira, o discurso trágico é reflexo e expressão do modo de ser do homem grego em relação ao espaço público e privado. Sua matéria predominantemente épica revela o caráter cívico nacional, assim como a transformação da liberdade e individualidade do cidadão grego, da liberdade pública, política, do povo, para a liberdade individual também é refletida nesse discurso.

\footnotetext{
${ }^{100}$ Hybris é um termo grego que significa o desafio, o crime do excesso e do ultraje. Traduz-se num comportamento de provocação aos deuses e à ordem estabelecida. A hybris revela um sentimento de que leva os heróis da tragédia à insubmissão e à violação das leis dos deuses, da polis, da família ou da natureza.
} 
Conclui-se que a natureza e influência da tragédia não devem ser consideradas de um ponto de vista exclusivamente estético, mesmo porque não havia uma divisão entre a ética, a política e a estética, tendo a tragédia uma pretensão global. Ela era uma forma de expressão a tal ponto hegemônica na polis que chegava a ser responsável por todo o espírito da comunidade, sendo que os trágicos não eram só criadores, mas representantes desse espírito, portadores do discurso e da ação.

A cada primavera, três poetas previamente escolhidos tinham a oportunidade de apresentar três tragédias, que eram julgadas pelos cidadãos e o vencedor escolhido (SOLON, 2010). O público era capaz de sentir a força da psicagogia ${ }^{101}$, de emocionar-se, tamanho o poder das palavras e da dramaturgia sobre o público. Entretanto, a força desta poesia não derivava da sua referência à realidade cotidiana dos gregos, mas sim dos dramas míticos ${ }^{102}$, da verdadeira linguagem do ser. A tragédia conseguia abalar a comodidade da existência cotidiana, por meio de uma fantasia poética extremamente dinâmica, audaciosa e elevada: transcendia e superava a realidade. O expectador era elevado acima de si próprio, criando um mundo comum, uma verdade comum a todos e transformadora.

O poder imediato da tragédia sobre o público é ainda maior do que o da epopéia homérica, tornando seu discurso ainda mais poderoso, por conta, dentre outros elementos, da concentração de um destino humano inteiro no breve curso dos acontecimentos dramáticos, que se desenrolam ante os olhos e ouvidos dos espectadores. A representação cênica era capaz de traduzir os próprios sentimentos do poeta para o eu estanho do ator e do público. No caso de Ésquilo, a polis é o espaço ideal e não acidental de seus poemas, sendo que os personagens falam politicamente, como nas grandiosas palavras que encerram As Eumênides (ÉSQUILO, 458 a.C.):

\footnotetext{
${ }^{101}$ Psykhagogia (psykhe + ago = alma + condução), que em uma primeira aproximação poderíamos traduzir por "condução da alma". Em relação à tragédia, tal termo era usado para designar a força persuasiva de uma peça, a força de comoção. As tragédias não eram representadas para divertir, mas sim para converter a uma maneira de ver o mundo (PINHEIRO, 2004, pp. 20-21)

${ }^{102}$ A representação do mito na tragédia não é um recurso meramente estilístico, ou um tema qualquer, mas possui uma profundidade inimaginável. Tampouco, limita-se à dramatização exterior que torna a narração uma ação participada, mas penetra no que as pessoas têm de mais profundo, em todos os envolvidos.
} 


\section{CORO}

Marchai à frente, divindades fortes, filhas sem filhos da fecunda Noite, sedentas de homenagens, ombreando com um cortejo composto de amigos até chegar à gruta subterrânea.

- Pronunciai bons votos, habitantes! -

Lá vos esperam santas oferendas e sereis cultuadas como deusas. - Pronunciai bons votos, habitantes! Propícias e leais a esta terra, segui vosso caminho, augustas deusas;

rejubilai-vos com a luz das tochas que, afogueadas, indicam a rota.

- Gritai agora, obedecendo aos ritos, numa resposta ao nosso canto estrídulo! O povo preferido por Atena acaba de ganhar a paz aqui para a felicidade de seus lares, e assim vemos selar-se a união entre as Parcas e Zeus onividente!

- Gritai agora, obedecendo aos ritos, numa resposta ao nosso canto estrídulo!

A tragédia de Ésquilo seria, assim, a ressurreição do homem heróico dentro do espírito da liberdade, como portador do destino, que é o verdadeiro protagonista da tragédia. A tragédia de Sófocles, por seu turno, busca demonstrar a fragilidade do agir. Ésquilo e Sófocles são os verdadeiros trágicos, ao passo que Eurípedes inicia uma deturpação do mito na tragédia, prefigurando a filosofia como ciência e o mundo da techne, mundo este que anuncia o encobrimento e esquecimento do ser. 


\section{A FUNÇÃO SOCIAL DA OBRA LITERÁRIA E DO ESCRITOR}

Neste ponto, considerando a discussão perpetrada no segundo capítulo acerca da obra literária de cunho social e humanitário, deve-se destacar que o discurso literário autêntico precisa ser de caráter espontâneo e revelar a alteridade de seu autor; principalmente, por meio da visão de mundo dele que a coloca à disposição dos leitores no espaço público. O texto literário, em sua faceta discursiva, não necessariamente carrega uma perspectiva ideológica determinada, mas mesmo quando o faz, deve trazê-la de uma forma especial, de modo que não surja um panfleto político, e sim uma representação reveladora da alteridade do agente e de superação do mundo. Veremos, portanto, que acima de tudo a obra literária é um ato libertador.

Já tratamos da obra literária autêntica como expressão autêntica do artista e a importância dela para a promoção e efetivação da liberdade dos homens, sendo que a idéia de que a obra literária é algo incondicionado, repousa na hipótese de uma virtude criadora do escritor, misteriosamente pessoal. Esse mistério sobreviverá, inclusive, à mais profunda análise, tendo em vista que o ato da leitura espontânea não pretenderá traçar os limites da virtude criadora do escritor. Mesmo quando tentamos delinear esses fatores, percebemos que os mais significativos são internos, "que costeiam a zonas indefiníveis da criação, além das quais, intacto e inabordável, persiste o mistério" (CANDIDO, 2006b, p. 83). Os fatores externos que influenciam a criação existem e são determináveis sociologicamente, porém, são claramente secundários. Sua determinação é, sobretudo, importante não à sondagem profunda das obras e dos criadores, mas à compreensão dos períodos e correntes literárias; o que não é interessante ao diálogo literário e ao verdadeiro conhecimento da literatura, mas sim à pretensão de tornar o estudo da literatura uma ciência.

A literatura é expressão do artista e de suas vivências; todavia, não se limita ao momento da criação, confiando sua consumação ao público. É inevitável, portanto, a começar pela linguagem, que o artista não faça uso, na criação, do arsenal comum da tradição. Além disso, sua obra necessariamente passará a compor esse arsenal comum, que será compartilhado por escritores e leitores futuros. Desse modo, a criação surge também de uma relação entre o grupo criador e o receptor. Autor e leitor compartilham um mundo comum: é esse mundo que o autor impregna com sua liberdade e a partir do qual o leitor deve realizar sua libertação concreta. E, como as liberdades do autor e do leitor se 
procuram e se afetam por meio de um mundo criado por eles, a escolha do autor por determinada visão de mundo que se deseja retratar é determinante na escolha do leitor da obra; e, reciprocamente, é escolhendo seu leitor que o escritor opta por determinado tema (SARTRE, 2006, p. 58).

O escritor, além de ser um indivíduo capaz de exprimir sua autenticidade, desempenha em muitos contextos também um papel social definido, que passa a compor a tensão existente entre as veleidades profundas de sua individualidade e a consonância ao meio e às expectativas do público. É evidente que como nos interessa também a literatura como experiência humana, não apenas como produção de obras consideradas transformações de modelos literários profundos, a literatura desperta inevitavelmente o interesse pelos elementos contextuais: somos levados a eles pela preocupação com nossa identidade e com nosso destino. Assim, nos interessa saber como o texto se forma a partir do contexto, até constituir uma independência dependente (CANDIDO, 2002, p. 79).

A literatura surge como uma síntese de tendências universalistas e particularistas; não só como um modo de expressão, que adquire uma existência própria, mas também como sistema simbólico por meio do qual as fantasias profundas do indivíduo se transformam em elementos de contato entre os homens e de interpretação das diferentes esferas da realidade, cumprindo um papel social. Vale ressaltar neste ponto que existe uma grande diferença entre as explicações que definem o papel social do escritor, de um lado, pelo meio e, de outro, pelo público. A explicação de que o papel social da obra e do escritor se define pelo meio em que este vive é extremamente pobre e determinista, posto que nesta explicação o meio produziria o escritor; enquanto que o público, ao contrário, interroga sua liberdade ${ }^{103}$. Se quisermos ver nas obras o reflexo dos fatores iniciais, achando que elas valem na medida em que os representam estaremos errados: as obras valem porque inventam uma vida nova, segundo a organização formal, tanto quanto possível nova, que a imaginação imprime ao meio (CANDIDO, 2006b, pp. 35-37). Dessa forma, não há quebra da autenticidade do escritor quando pensamos na relação deste com o público, mas sim quando ele é um mero produto do meio, tendo em vista que o projeto de escrever deve ser justamente a superação dessa situação dada.

${ }^{103} \mathrm{O}$ público é uma expectativa, um vazio a ser preenchido, uma aspiração. O público intervém, com seus costumes, sua visão de mundo sua concepção da sociedade e da literatura; cerca o escritor, investe-o (SARTRE, 2006, pp. 60-61). 
O exemplo da Independência brasileira e da literatura posterior à ela; que tentava desprender-se e diferenciar-se da literatura portuguesa, por outros traços que não a língua, comum a ambas; é bastante ilustrativo para que se perceba como a dinâmica existente entre escritor, meio e ideologias dominantes podem afetar o papel social da literatura em dado momento, bem como a autenticidade das obras (CANDIDO, 2006b, p. 88).

Silva Alvarenga (1749-1814) foi provavelmente o primeiro escritor brasileiro que procurou harmonizar a criação e a militância intelectual, graças ao senso quase didático do seu papel. Em torno dele formou-se a Sociedade Literária, que se prolongou pelos alunos por ele formados, sendo, alguns partidários da Independência. Alvarenga, em virtude do clima de desconfiança gerado pela Inconfidência Mineira, foi detido em 1794 e permaneceu preso por mais de dois anos. O vice-rei enxergava na Sociedade Literária, que reunia estudiosos e homens de letras, sinistros projetos de conjura contra o poder real. Evidentemente que as associações literárias representavam espaços políticos importantes, ameaçando o status quo: com base em sua experiência como Mestre de Retórica e Poética, Silva Alvarenga difundiu a concepção do homem de letras como agente na vida civil, animando um movimento que teve continuidade, criando pequenos públicos que se ampliariam pela ação cívica e intelectual, culminando com as reivindicações de autonomia política e literária (CANDIDO, 2006b, p. 88). Colaborou, ainda, n'O Patriota de Manuel Ferreira de Araújo Guimarães, uma revista literária que fomentou o movimento intelectual anterior à Independência.

A literatura teve um papel decisivo, ainda, na determinação do Brasil enquanto povo independente e autêntico. O Indianismo constituiu uma elaboração ideológica do grupo intelectual em resposta às necessidades do momento histórico posterior à Independência, exercendo uma função social importante, conquistando a aprovação do público disponível, atuando ativamente sobre ele. Todavia, essa tendência literária não possuía raízes populares, mas sim eruditas, tendo os intelectuais reconhecido, no índio, o protótipo da virtude natural.

O Arcadismo no século XVIII foi uma espécie de identificação com o mundo europeu por meio do seu homem rústico idealizado na tradição clássica, ao passo que, já no século XIX, o Indianismo foi identificação com o mundo não europeu pela busca de um homem rústico americano igualmente idealizado. O Regionalismo, que o sucedeu, foi uma busca do tipicamente brasileiro por meio das formas de encontro, surgidas do contato entre o europeu e o meio americano. O que nos compete mencionar é que sua função social foi ao mesmo tempo humanizadora e alienadora, conforme o autor e a obra considerados em sua autenticidade. 
A expressão nacionalista da época, em seu aspecto humanizador, contribuiu para a auto-valorização da sociedade do novo Brasil. O curioso é que o público não se limitou ao público dos leitores, tendo em vista que o temário nacionalista e sentimental operou também na canção, no discurso, na anedota, nas artes plásticas, propiciando a formação de um público incalculável, possivelmente o maior complexo de influência literária junto ao público que já houve entre nós (CANDIDO, 2006b, p. 92). Assim, a influência do movimento literário desse período dialogou com públicos diversos, extrapolando os habilitados para a leitura compreensiva. O espaço político desencadeado pelo movimento literário da época foi além da própria literatura em sentido estrito.

Vale ressaltar que o nacionalismo artístico não deve ser condenado ou louvado em abstrato, sendo fruto de uma condição histórica e existencial de um povo ${ }^{104}$. Esse processo leva à realização de um esforço dos setores da vida mental e artística de glorificação dos valores locais, dando lastro, tema e significado a formas polidas, mas incaracterísticas. Compromete, contudo, em certa medida, a universalidade da obra, que acaba fixando-se no dado momento histórico (CANDIDO, 2006a, pp. 25-30).

Não há dúvida, no entanto, que, no Brasil, a necessidade de adequação aos padrões do grupo custou a independência ideológica dos artistas, que dependiam das instituições governamentais $^{105} \mathrm{e}$, portanto, da ideologia dominante para ter a atividade literária acolhida como função digna. Evidentemente que a legitimação do papel político do escritor era muito maior em virtude da vinculação à administração; todavia, isso comprometia sua expressão autêntica. Poucos os escritores indianistas que conseguiram garantir a sua liberdade, a despeito da defesa da ideologia nacionalista. A ação política, nesse sentido, perdia sua novidade e sua espontaneidade necessárias ao espaço político livre. Esses escritores possuíam, portanto, pouco da gratuidade que dá asas à obra de arte e muito da fidelidade documentária ou sentimental. Aliás, a espontaneidade do gratuito, que seria uma prova de amadurecimento do escritor e do povo, ao jovem povo brasileiro, parecia traição e fraqueza (CANDIDO, 2006a, pp. 25-30).

O que acabou por ocorrer, ao longo do século XIX, foi uma reação por parte dos boêmios e dos estudantes das faculdades de direito, que muitas vezes eram os escritores

\footnotetext{
${ }^{104}$ Quase imposição nos momentos em que o Estado se forma e adquire fisionomia nos povos antes desprovidos de autonomia e unidade, como uma estratégia de autodeterminação.

${ }^{105}$ Os escritores que se conformassem à ideologia, além de terem seu trabalho reconhecido - em vista do nacionalismo constituir um critério que atestava a própria "qualidade" da obra e estabelecia uma esfera comum na qual ocorria a comunicação - eram oficialmente amparados pelo Imperador D. Pedro II, pelo Instituto Histórico, bem como pelas Faculdades de Direito (Olinda-Recife e São Paulo). Uma padronização era imposta ao comportamento do escritor, podando suas demasias; em contrapartida, este era funcionário pensionado, agraciado e apoiado de qualquer modo, como em um mecenato que vinculava as letras e o literato à administração e à política.
} 
antes da idade burocrática, antes de terem o papel cívico e construtivo da nacionalidade justificando sua atividade perante o Estado ${ }^{106}$. Evidentemente que mesmo esse elemento renovador e dinamizador acabou por ser parcialmente racionalizado pelas ideologias dominantes, uma vez que, quando os jovens escritores cresciam, passavam a receber o apoio do Império encartolado:

(...) a atitude paternal do Governo, numa sociedade em que o escritor esperava acomodar-se nas carreiras paralelas e respeitáveis, que lhe permitiriam viver com aprovação pública, redimindo ou compensando a originalidade e a rebeldia. Por isso mesmo, talvez tenha sido uma felicidade a morte de tantos escritores de talento antes da servidão burocrática (CANDIDO, 2006b, p. 93).

Finalmente, ao longo do século XX, o escritor foi se consolidando como legítimo portador do discurso. De um lado isso se deveu à profissionalização, que acentuou a participação na vida social, o refinamento e a autenticidade; de outro, à diversificação dos públicos e diferenciação entre as elites intelectuais e as administrativas e econômicas.

Dessa forma, a literatura dita autêntica é capaz de constituir, ela própria, um espaço político livre, uma expressão da vita activa. Contudo, é muito difícil escapar à inautenticidade quando o papel social do escritor demanda certo reconhecimento institucional para que sua obra venha a cumprir um papel social. O impessoal também submete a criação literária a uma tonalidade média, enquadrando a expressão nas bitolas de gosto. Muitos dos maiores escritores brasileiros foram homens ajustados às superestruturas administrativas, como Gonçalves Dias e Machado de Assis. Contudo, mesmo quando o escritor é parte de uma classe opressora, não é seu cúmplice; sua obra continua sendo libertadora, tendo em vista que tem como efeito, mesmo que no interior dessa classe, libertar o homem de si mesmo (SARTRE, 2006, p. 77).

Assim, seria preciso ver além da mera ocasião política para compreender o papel da literatura em relação ao seu público, derivado principalmente da compreensão e do diálogo, que, em sua forma mais pura, supera a ideologia que predomina e ofusca a representação da obra. Esse papel de abertura dos indivíduos para a diversidade, a sociedade, o semelhante e para a compreensão do mundo é o ganho político e humano mais importante que se poderia ter.

\footnotetext{
${ }^{106}$ Esse movimento, em especial o dos estudantes da Faculdade de Direito do Largo São Francisco, foi descrito com mais detalhamento no segundo capítulo.
} 


\section{O ESCRITOR E O PÚBLICO}

A arte e a literatura enquanto arte produzem sobre os leitores um efeito prático, modificando sua conduta e concepção do mundo, ou reforçando o sentimento e os valores sociais já professados por eles. Esse efeito mais ou menos transformador da literatura é uma etapa fundamental da constituição de seu modo de ser, tendo em vista que a literatura só está acabada no momento em que repercute e atua. Sua existência precisa ser consumada na leitura e na interpretação. A literatura também se constitui como um processo comunicativo, que é integrador e bitransitivo por excelência:

(...) o objeto literário é um estranho pião, que só existe em movimento. Para fazê-lo surgir é necessário um ato concreto que se chama leitura, e ele só dura enquanto essa leitura durar. Fora daí há apenas traços negros sobre o papel. Ora, o escritor não pode ler o que escreve, ao passo que o sapateiro pode calçar os sapatos que acabou de fazer, caso estes the sirvam, e o arquiteto pode habitar a casa que construiu (SARTRE, 2006, p. 35).

O movimento é dinâmico e fluido como um jogo, sendo que a obra possui uma ação sobre o público, na época da criação e na posteridade. O momento da leitura recria a obra, que é reiluminada por um novo olhar e recebe novas luzes e contornos sobre as palavras. Assim, também o escritor passa a verdadeiramente ouvir e conhecer seu próprio discurso e a si próprio, uma vez que o vê pelo prisma da interpretação dos leitores, adquirindo plena consciência da obra e do impacto desta. O público para quem se dirige o escritor serve como ponto de referência ao escritor, na medida em que a interpretação dos leitores constitui um diálogo vivo com a obra, uma fusão de horizontes. A resposta do leitor à obra é, portanto, a definição do próprio escritor, que, no momento da leitura, existe no mundo com o outro, e por meio dele se determina:

Quando se diz que escrever é imprescindível ao verdadeiro escritor, quer isto dizer que ele é psiquicamente organizado de tal modo que a reação do outro, necessária para a autoconsciência, é por ele motivada através da criação. Escrever é propiciar a manifestação alheia, em que nossa imagem se revela a nós mesmos (CANDIDO, 2006b, p. 86).

É possível que esse entendimento que se dá no ato da leitura, originado, evidentemente, pela novidade do discurso e da criação, ajude a compreender a citação de Lispector que inicia o presente capítulo: a busca de si próprio do escritor que se dá por 
intermédio do outro, do contato intangível com o leitor; e a busca do leitor por meio da obra e da visão de mundo do outro.

Assim como a criação só pode encontrar sua realização final na leitura, também somente por meio da consciência de outrem o escritor pode perceber-se essencial à sua obra: toda obra literária constitui o reconhecimento do outro ${ }^{107}$, na medida em que é um apelo. Escrever é "apelar ao leitor para que este faça passar à existência objetiva o desvendamento que empreendi por meio da linguagem" (SARTRE, 2006, p. 39). E mais: não se trata de um apelo abstrato, o escritor apela para que o leitor se valha de sua liberdade na recriação de sua obra. Para atingir a liberdade do leitor é preciso reconhecê-la e confiar nela, abrindo-se e entregando-se ao exercício da liberdade do outro, que toma, por seu turno, total responsabilidade. O livro não é uma ferramenta para a liberdade, mas ele se propõe como fim para a liberdade do leitor.

Assim, "se recorro a meu leitor para que ele leve a bom termo a tarefa que iniciei, é evidente que o considero como liberdade pura, puro poder criador" (SARTRE, 2006, p. 41). O escritor, quando escreve, elabora um apelo ao leitor, reconhecendo sua liberdade, tão grande e criadora quanto à dele própria, determinando sua obra e ele próprio por meio do caminho que passa pela liberdade do outro. A relação que se estabelece com o outro, portanto, não é de dominação da passividade alheia por meio da literatura, mas de determinação dos indivíduos que agem e se transformam mutuamente, tendo por fim a construção da obra, de um universo comum.

Um conceito importante em Sartre, para além do reconhecimento, é o conceito de generosidade. Quando o objeto não domina as afeições do leitor, mas estas encontram sua fonte permanente e seu fim na liberdade, elas podem ser chamadas de generosas. Assim, de ambos os lados, a literatura é um exercício de generosidade. O escritor não pede ao leitor que faça uso de uma liberdade abstrata, mas a doação de toda a sua pessoa, com suas paixões, suas prevenções, suas simpatias e sua escala de valores. A entrega do leitor deve ser generosa, sendo atravessado de lado a lado pela liberdade. O escritor que deposita sua confiança no leitor exige ter essa confiança retribuída, ou seja, que o leitor reconheça sua liberdade criadora e a solicite, reciprocamente. Trata-se de um pacto de generosidade. Assim, em um processo dialético, quanto mais experimentamos a nossa liberdade, mais

\footnotetext{
${ }^{107} \mathrm{Na}$ medida em que pensar em direitos humanos tem como pressuposto reconhecer que aquilo que consideramos indispensável para nós também é indispensável para o próximo, é parte absolutamente indispensável desse pressuposto o reconhecimento do outro como um próximo, compartilhando com ele os mesmos direitos que reivindicamos.
} 
devemos reconhecer a liberdade do outro; quanto mais depositamos confiança no outro, mais o outro conta conosco, para que a literatura possa ser.

Um ato de generosidade muito claro é o que ocorre quando o autor, imbuído de paixão, toma a decisão de escrever. Essa decisão implica que ele deve tornar suas emoções explícitas e claras para que o leitor possa entendê-las e deve confiar no leitor para que ele as interprete e as traga à vida. Por outro lado, o leitor amargo e embrutecido pela vida exerce um ato de generosidade quando aceita ser invadido pelas paixões que a literatura carrega de lugares e tempos distantes.

Assim, não só a escrita, mas também a leitura é ato: a passividade transformada em ato. Também a leitura é uma forma de manifestação do ser, de discurso silencioso. No momento da leitura, o leitor pode tornar-se aquilo que seria se não tivesse passado a vida mascarando sua liberdade (SARTRE, 2006, pp. 42-46).

Não obstante ninguém poder obrigar o escritor a crer que o leitor fará uso de sua liberdade, ou o leitor a pensar que o escritor tenha feito uso da sua - trata-se de uma decisão livre que ambos tomam independentemente -, quanto mais manifestas, enquanto escritor, minha generosidade e confiança, mais exigirei do leitor e mais o incitarei a manifestar as suas.

A literatura não se constitui somente pelo conjunto das obras literárias, mas também pelo movimento do sistema vivo que essas obras são. Como qualquer espaço político e comunicativo, o modo de ser literário é vivo, de forma que as obras agem uma sobre as outras e sobre os leitores, e só vive na medida em que estes as vivem, decifrandoas, aceitando-as, transformando-as (CANDIDO, p. 84).

O caminho para a criação de um espaço político literário passa, evidentemente, pela existência do público de leitores. No Brasil, essa relação do escritor como seu público imediato sempre foi bastante delicada. Em um primeiro momento passava pela intermediação do Estado, que, independentemente da apreciação do público, garantia ao escritor uma posição social definida e confortável. Todavia, o público de leitores no Brasil sempre foi reduzido. $\mathrm{O}$ escritor nunca conseguiu atingir amplamente as massas, tendo em vista a imensa quantidade de iletrados que sempre existiu e ainda existe no país, a despeito de a taxa de analfabetismo estar reduzindo ${ }^{108}$. Por conseguinte, desvencilhar-se do apoio

\footnotetext{
${ }^{108}$ Taxa de analfabetismo*: entre 1986 e 1997 a taxa de analfabetismo da população de 15 anos e mais de idade passou de 20,0\% para 14,7\%. Os valores para os anos de 1987, 1988, 1989, 1990, 1991, 1992, 1993 e 1995 foram, respectivamente, $20,0 \% ; 17,0 \% ; 19,7 \% ; 19,0 \% ; 19,0 \% ; 18,3 \% ; 16,3 \%$ e $15,5 \%$.
} 
das elites representa uma coragem existencial ainda mais significativa. $\mathrm{O}$ escritor corre o risco, mesmo quando rejeita o apoio das elites, de cair em uma dissimulação da relação real com o grande público, bem como na reconstituição de um público de especialistas, isolando-se em uma espécie de clericato, não conseguindo sequer extrair prazer de seus próprios livros.

Para Sartre (2006, pp. 92-99), o escritor que pretende escrever para um público virtual, ou seja, para um público do qual não se origina, deveria determinar sua arte a partir de exigências exteriores à sua essência, renunciando a diversas formas da narrativa, da poesia, do próprio raciocínio, pelo simples motivo de que não seriam acessíveis aos leitores menos próximos ao mundo das letras. Reconhece, contudo, que essa renúncia poderia jogar a literatura na alienação, alienação tão forte quanto a dos escritores elitistas que realisticamente repetem o meio em que vivem ${ }^{109}$. O que acaba por ocorrer, frente a essa constatação, é que os escritores recusam-se a sujeitar suas obras ao público mais iletrado, o que significa, no entanto, um divórcio da transformação concreta, condenando sua ruptura a permanecer simbólica. Assim, qualquer pretensa revolução literária, centrada no refinamento técnico, serviria ao conservadorismo social. Contudo, é importante que enxerguemos outros caminhos, que não passam pela renúncia à qualidade, mas sim pela promoção dos direitos à cultura e à educação; de forma que os potenciais leitores possam tornar-se leitores de fato.

(IBGE, Censo Demográfico 1991 e Pesquisa nacional por amostra de domicílios 1986-1990, 1992-1993, 1995, dados não publicados).

\begin{tabular}{|c|c|c|c|c|c|c|}
\hline \multirow{2}{*}{$\begin{array}{l}\text { Brasil e Grandes } \\
\text { Regiões }\end{array}$} & \multicolumn{3}{|c|}{$\begin{array}{l}\text { Taxa de analfabetismo das pessoas de } 15 \text { anos } \\
\text { ou mais de idade }\end{array}$} & \multicolumn{3}{|c|}{$\begin{array}{l}\text { Taxa de escolarização das crianças de } 7 \text { a } 14 \\
\text { anos de idade }\end{array}$} \\
\hline & Total & Homens & Mulheres & Total & Homens & Mulheres \\
\hline Brasil (1) & 13,3 & 13,3 & 13,3 & 95,7 & 95,3 & 96,1 \\
\hline Norte (2) & 11,6 & 11,7 & 11,5 & 95,5 & 95,3 & 95,7 \\
\hline Nordeste & 26,6 & 28,7 & 24,6 & 94,1 & 93,2 & 95,0 \\
\hline Sudeste & 7,8 & 6,8 & 8,7 & 96,7 & 96,6 & 96,9 \\
\hline Sul & 7,8 & 7,1 & 8,4 & 96,5 & 96,7 & 96,3 \\
\hline Centro-Oeste & 10,8 & 10,5 & 11,0 & 96,0 & 95,6 & 96,4 \\
\hline
\end{tabular}

Fonte: Pesquisa nacional por amostra de domicílios 1999 [CD-ROM]. Microdados. Rio de Janeiro: IBGE, 2000.

(1) Exclusive a população rural de Rondônia, Acre, Amazonas, Roraima, Pará e Amapá.

(2) Exclusive a população rural.

* Taxa de analfabetismo: percentagem das pessoas analfabetas $\left(^{*}\right)$ de um grupo etário, em relação ao total de pessoas do mesmo grupo etário.

(*) Analfabeta: pessoa que não sabe ler e escrever um bilhete simples no idioma que conhece.

Taxa de escolarização: percentagem dos estudantes de um grupo etário em relação ao total de pessoas do mesmo grupo etário.

${ }_{109}$ Alguns escritores constituem-se como testemunhas imparciais de sua época, todavia, "não testemunham aos olhos de ninguém; elevam ao absoluto o testemunho e as testemunhas, apresentando ao céu vazio o panorama da sociedade que os rodeia. Ludibriados, transpostos, unificados, prisioneiros na armadilha de um estilo artista, os eventos do universo são neutralizados e, por assim dizer, colocados entre parênteses; o realismo é uma 'epoché"” (SARTRE, 2006, p. 99). Vale argumentar, contudo, que a literatura realista não é necessariamente uma cópia vazia da realidade. Muitas vezes, ela traz uma crítica que "assume o cunho da verdadeira investigação orientada da sociedade" (CANDIDO, 2004, p. 185). 
Na opinião de Mario de Andrade, hoje já dominante, todos os níveis de cultura são dignos, sendo que ele entendia que as criações populares seriam as fontes das eruditas, e que, de modo geral, a arte vinha do povo (CANDIDO, 2004, p. 188). Há uma corrente em dois sentidos, uma troca de influências constante entre as esferas erudita e popular, fazendo da criação artística um fenômeno intercomunicativo. Assim sendo, esses dois modos de expressão do mundo bastante diversos devem ser capazes de estabelecer um diálogo para que esse movimento possa ocorrer de forma a alimentar e transformar as criações em ambos os sentidos, o que, contudo, não pode representar uma queda na qualidade e perda de autenticidade das manifestações.

$\mathrm{Na}$ análise que Antonio Candido realiza da penetração da literatura nas camadas sociais, ele considera que, envolvendo o problema da desigualdade social e econômica, está o problema da intercomunicação dos modos de ser da cultura: popular e erudito. Assim, "nas sociedades que procuram estabelecer regimes igualitários, o pressuposto é que todos devem ter a possibilidade de passar dos níveis populares para os níveis eruditos (...)" (CANDIDO, 2004, p. 188); no entanto, nas sociedades em que impera a desigualdade, devem ocorrer movimentos, públicos ou privados, para que o povo possa ter contato com os produtos eruditos. O principal obstáculo para esse diálogo entre os modos de ser da cultura pode ser, portanto, a falta de oportunidade (CANDIDO, 2004, p. 188).

Por todo o exposto, é importante que consideremos que a existência de uma literatura que dialogue com as massas não deve significar a produção de obras de baixa qualidade e pobreza cultural, sob pena de se provar dos efeitos mutiladores da segregação cultural segundo as classes. Quer a obra pode nascer autêntica na própria esfera da cultura popular, quer pode dialogar com esta cultura. Nesse sentido, tratando do acesso dos iletrados à literatura escrita, Antonio Candido (2004, p. 190) narra um episódio de sua juventude bastante simbólico esclarecedor:

Se for permitida outra lembrança pessoal, contarei que quando eu tinha doze anos, na mesma cidade de Poços de Caldas, um jardineiro português e sua esposa brasileira, ambos analfabetos, me pediram para lhes ler o Amor de perdição, de Camilo Castelo Branco, que já tinham ouvido de uma professora da fazenda onde trabalhavam antes e que os havia fascinado. Eu atendi e verifiquei como assimilavam bem, com emoção inteligente.

Entretanto, vem ocorrendo com os escritores que pretendem atingir grandes públicos algo ainda pior do que a produção de obras que se limitam a veicular um discurso político, sem qualquer originalidade do artista: eles acabam por sucumbir sua literatura ao 
impessoal, às possibilidades já existentes e já apresentadas pelo gosto de um público inautêntico. Além disso, acabam por produzir um discurso absolutamente artificial, não espontâneo. Esse movimento jamais conseguirá expressar qualquer discurso que não os já existentes, senão os que mostrem aos leitores os horizontes e as perspectivas que eles já conhecem, sem o nascimento de qualquer nova vida ou possibilidade. Dessa forma, não se realiza um diálogo a partir da experiência literária, mas o discurso uníssono da massa indiferenciada. A igualdade não se consuma na homogeneidade, mas sim a partir da abertura e do reconhecimento produzidos a partir da experiência dialógica.

Principalmente em nosso tempo, o público indireto proporcionado pela literatura escrita, derivado de contatos secundários, passa a não mais constituir um grupo, mas um conjunto informe, isto é, sem estrutura, de onde podem ou não desprender-se agrupamentos configurados. Existem, na sociedade contemporânea, várias dessas coleções informes de pessoas, espalhadas por toda parte, formando os vários públicos das artes. Essas coleções aumentam e se fragmentam à medida que cresce a complexidade da estrutura social. A ação do público sobre o artista sempre foi grande; porém, hoje, essa influência adquire proporções tão gigantescas quanto o público consumidor das literaturas cada vez menos autênticas. Cada vez menos a literatura vem cumprindo o seu papel de exercício espontâneo da autenticidade e da liberdade, e, portanto, de efetivação dos direitos humanos através da vida dos indivíduos. Entretanto, a literatura ainda oferece esse serviço àqueles que se aventurarem a conservarem-se autênticos e não se renderem à comodidade do impessoal. Deve-se perceber que mesmo a literatura vinculada a um contexto social atinge públicos de proporções infinitas, multiplicados pela perspectiva mercadológica. Isso multiplica o risco da diluição dos ideais outrora autênticos e espontâneos em tentativas, cada vez mais eficientes, de obtenção de lucro e de poder político sem propósito autêntico e sincero.

Existem algumas formas adquiridas pela literatura, que conservam relativa autonomia, às margens do mercado, que procuram construir um campo de linguagem comum entre a obra literária e o leitor, para que nesse espaço comum o jogo do diálogo possa ocorrer. O teatro, por exemplo, é a forma de interpretação que dá vida à obra literária, recriando-a. A interpretação teatral não é distinta da obra, mas se torna uma com ela. A obra passa a falar por meio da interpretação, que é a primeira etapa do diálogo; uma etapa que intermedia a obra de dramaturgia, ininteligível, e o público que não pode compreender a linguagem escrita. O cinema, mais recentemente, tem conseguido realizar essa construção; de uma forma um pouco diferente, buscando um público ainda maior que o teatro, e cada vez mais criando espaços livres das determinações do consumo e do gosto do impessoal. Referidas interpretações, quando conseguem fazer-se em um diálogo não 
dominador, mas sim a partir da genuína compreensão, não distorcem a obra literária, mas são formas por intermédio das quais ela pode vir à fala.

No Brasil, a tradição de auditório, por exemplo, prosseguiu por todo o século XIX, até o início do século XX, não somente graças à grande voga do discurso em todos os setores da vida, mas também graças à interpretação recitativa e à musicalização dos poemas. Foram estas as principais formas de se veicular a poesia em públicos mais amplos. Românticos e pós-românticos penetraram melhor na sociedade graças a públicos receptivos de auditores. Antonio Candido (2006b, p. 94) não nos deixa esquecer que para o homem do povo, a encarnação suprema da inteligência e da literatura foi um orador, Rui Barbosa (1849-1923), que quase ninguém lê fora de algumas páginas de antologia. Havia, ainda, serões em que as revistas e jornais familiares eram lidos em voz alta. Nesses casos, os autores se voltavam para um público majoritariamente feminino, penetrando no espaço familiar e atingindo indivíduos que raramente possuíam contato com as idéias no espaço público.

Na primeira metade do século XX houve alterações importantes no panorama da literatura brasileira ${ }^{110}$, principalmente no que diz respeito à ampliação relativa dos públicos, ao desenvolvimento da indústria editorial e às possibilidades de remuneração específica dos escritores. Dessa forma, a literatura passou a se desoficializar e adquirir certa independência ideológica; a partir de 1922 o escritor desafogou, passou a ter um papel mais liberto, mesmo que continuasse a participar da vida e das aspirações nacionais. Quanto aos públicos, houve uma diferenciação, surgindo alguns mais receptivos para a vida literária, suscitando maiores aventuras e um maior nível de inconformismo nas obras. Outra importante mudança é que no século XX, diferentemente do que ocorria no século XIX, as elites intelectuais não coincidiram sempre com as elites administrativas e políticas, constituindo um público refinado, independente dos quadros governamentais (CANDIDO, 2006b, p. 97)

Ao final do século XX e início do XXI, a evolução da acessibilidade da literatura ocorreu paralelamente nesses dois campos: (i) no desenvolvimento da literatura voltado para a oratória, que viria a tomar amplas proporções com o desenvolvimento tecnológico ${ }^{111}$; (ii) no desenvolvimento de uma literatura que vem à fala por meio da leitura, com o enriquecimento da escrita e da leitura.

\footnotetext{
${ }^{110} \mathrm{O}$ século XIX foi para o escritor a época do erro e da queda, tendo em vista que grande parte dos escritores não aceitou o rebaixamento social, não se dirigindo, de fato, a um público dividido, perdendo a chance de ampliar ainda mais a generosidade que dá origem à literatura. Se os escritores da época fossem mais acessíveis e tivessem encontrado audiência junto às classes mais oprimidas, talvez seus escritos tivessem colaborado para constituir um movimento de idéias, com uma ideologia aberta, contraditória, dialética e dialógica, como resultado claro de um espaço político amplo e livre, acessível a todos.

${ }^{111} \mathrm{O}$ rádio reinstalou a literatura oral quando do seu surgimento e desenvolvimento. Um sentimento de missão social também surgiu em alguns romancistas, poetas e ensaístas, que não raro escrevem como quem fala para convencer ou comover. A televisão teria o poder de ampliar o movimento de acessibilidade à literatura, porém, a baixa qualidade dos programas frustra qualquer tentativa de se veicular uma literatura autêntica e emancipadora aos públicos mais iletrados; ao contrário do cinema que continua a criar formas para de interpretar e trazer a literatura à fala (CANDIDO, 2006b, p. 98).
} 
Assim, tanto o público de iletrados vem diminuindo, como também tem se investido de algumas estratégias que tendem a manter a literatura nos caminhos da facilidade e da comunicabilidade imediata, de literatura que tem muitas características de produção falada para ser ouvida, mas principalmente tem se investido na introdução da literatura escrita nas camadas sociais economicamente menos favorecidas. Temos como exemplo o Projeto PraLer - Prazeres da Leitura, que procura promover atividades de incentivo à leitura em várias regiões da cidade de São Paulo, com o objetivo de propiciar o intercâmbio cultural e eliminar barreiras sociais e geográficas entre grupos vulneráveis (jovens em situação de risco e idosos) e os pólos de cultura da capital: "por meio de passeios e visitas monitoradas, a população se apropria dos locais públicos que a cidade oferece, como parques, museus, bibliotecas e livrarias, onde são realizadas atividades como oficinas de leitura e escrita, contação de histórias, apresentações teatrais e musicais e criação literária” (ESTADO DE SÃO PAULO, 2010).

Quando se trata do papel da literatura descrito no presente trabalho e se ressalta o seu potencial de adquirir autonomia e fluidez por sua forma escrita e por meio da recriação pela leitura, evidentemente que a criação literária voltada para a interpretação oral interpõe um intermediário. Essa mediação pode constituir um obstáculo maior ou menor a depender da qualidade e autenticidade da interpretação. O ideal seria, portanto, que a promoção da acessibilidade à literatura se desenvolvesse no segundo caminho proposto.

Também em termos culturais, o Brasil continua se distinguindo pela alta taxa de iniqüidade, confinando o povo a apenas uma parte da cultura, a dita popular. Essa diferenciação e segregação geram um preconceito fortíssimo segundo o qual as classes sociais mais pobres não saberiam apreciar e, portanto, não poderiam participar das formas chamadas "mais requintadas" de cultura. A privação de bens culturais infringida com base nesse falso argumento, muitas vezes travestido de benevolência, visa sempre à manutenção velada dos abismos sociais; de forma que o povo não possa ter acesso a uma liberdade que ultrapassa a barreira sócio-econômica, ou não possa ser alvo do reconhecimento proporcionado pela literatura. Quanto à oportunidade de ser o autor dessa forma de discurso e de atuar no espaço político, esta se torna ainda mais distante. 


\section{LITERATURA ENGAJADA}

Sartre considera o engajamento da obra como elemento essencial e determinante de sua possibilidade de promover a liberdade e o reconhecimento, uma vez que seu engajamento repousa essencialmente no apelo à liberdade e na generosidade; seria o que inunda e preenche toda literatura autêntica que pode vir a emancipar e promover os direitos humanos. Tendo em vista que a existência da obra depende de liberdades confluentes: do artista e do leitor, o único aspecto sob o qual o mundo poderia ser apresentado é o de um mundo a ser impregnado cada vez mais por liberdade:

Não seria concebível que esse desencadeamento de generosidade que o escritor provoca fosse empregado em consagrar uma injustiça e que o leitor desfrutasse da sua liberdade lendo uma obra que aprova ou aceita ou simplesmente se abstém de condenar a opressão do homem pelo homem.

(...)

Pois não se pode exigir de mim, no momento em que percebo que minha liberdade está indissoluvelmente ligada à de todos os outros homens, que eu a empregue para aprovar a servidão de alguns dentre eles. Assim, (...) quer fale somente das paixões individuais ou se lance contra o regime social, o escritor, homem livre que se dirige a homens livres, tem apenas o único tema: a liberdade (SARTRE, 2006, pp. 51-2).

$\mathrm{O}$ engajamento, que tem por fundamento o apelo à liberdade humana e sua promoção, realiza-se na medida em que o escritor é um mediador por excelência e faz sua espontaneidade passar do plano imediato ao refletido para si e para outros, com liberdade e generosidade. Isso não se define de forma simplificada pela temática da obra, mas no próprio fato literário, no modo de ser do escritor e da literatura: no modo dialógico e dialético. Muitas vezes, a temática tratada não é humanitária, mas na medida em que suscita e confia na liberdade alheia para a determinação da própria obra, já se realiza um apelo à liberdade humana. Esse engajamento se manifesta de maneira sutil, sem que o próprio escritor se dê conta $^{112}$, no próprio fato de que a liberdade de escrever implica a liberdade dos indivíduos, o reconhecimento recíproco, independentemente da ideologia professada na obra. $\mathrm{O}$ escritor somente pode ser essencial porque a existência e a liberdade o são.

\footnotetext{
${ }^{112}$ Se for verdade que o modo de ser da obra literária se dá pela liberdade que se descobre; e a literatura deseja ser um apelo à liberdade dos outros homens, é verdade também que as diferentes formas de opressão, escondendo dos homens sua liberdade, encobriram também a liberdade dos escritores para eles próprios (SARTRE, 2006, p.114).
} 
A literatura pode ser dita engajada e revolucionária não por emitir mensagens revolucionárias, mas por reordenar o real e reinventá-lo a partir da imaginação, fazendo se abater sobre a fatalidade do real uma dúvida radical, ousando supor que uma alternativa àquele seria possível. Assim também suscita a liberdade do escritor e do leitor, incidindo sobre o mundo de maneira indireta, ampliando a compreensão do leitor sobre ele e mostrando caminhos possíveis à sua liberdade (PERRONE-MOISÉS, L., 2006a, p. 108).

Muitas vezes, a literatura comumente dita não engajada representa uma fase preliminar necessária, trazendo uma visão de mundo transposta em fantasia, a uma práxis socialmente condicionada. Mas isso somente é possível em virtude da gratuidade, do teoricamente incondicionado, que introduz o leitor no mundo ilusório que vem a transformar-se dialeticamente em algo engajado (CANDIDO, 2006b, p. 65).

Considerar os temas sobre os quais trata a literatura uma questão em aberto, como solicitações, expectativas; não havendo temas que se situem a priori fora da arte literária; é um primeiro passo para ver o engajamento não como uma perda ou um ganho, mas uma escolha composta pela determinação de sobre o que se escreverá e como se escreverá ${ }^{113}$. Muitas vezes ocorre que as duas escolhas sejam uma só, mas devem ser sempre interdependentes, determinando-se uma pela outra; além disso, trata-se de uma escolha que depende das circunstâncias e de uma livre decisão do artista.

Podemos mencionar o exemplo do Regionalismo brasileiro, que estabelece uma curiosa tensão entre tema e linguagem. O tema rústico acaba por influenciar a linguagem no sentido de ser "inculta" e cheia de peculiaridades locais, enquanto a convenção da literatura erudita, baseada no postulado de uma inteligibilidade universal, influencia no sentido de uma linguagem culta ou mesmo acadêmica. O Regionalismo, portanto, deve procurar estabelecer uma relação adequada entre esses dois aspectos (tema e linguagem), tornando-se uma forma poderosa de transformação da língua e de revelação e autoconsciência do povo. Tomemos como exemplo dois autores de uma mesma fase: Coelho Neto (1864-1934) e Simões Lopes Neto (1815-1916) (CANDIDO, 2002, p. 87).

Ambos escreveram em um momento de grande voga da literatura regionalista, quando ela parecia mais autêntica do que outras modalidades. Cabe mencionar, contudo, que esta foi uma falsa tendência, correspondendo a modalidades superficiais de

113 É preciso que o escritor tenha a capacidade de criar uma organização literária adequada. O que na literatura age como força humanizadora é também a capacidade de criar formas pertinentes, todavia, isso não quer dizer que só serve a obra perfeita: em geral, um movimento literário é constituído por textos de qualidade alta e de qualidade modesta, formando no conjunto uma massa de significados que influi em nosso conhecimento e em nossos sentimentos (CANDIDO, 2004, p. 182). 
nacionalismo, tendo se constituído um abismo insuperável entre o escritor e seus personagens, que ficava reduzido ao nível do curioso e do exótico. Não obstante, alguns escritores conseguiram superar essa barreira.

A escrita de Coelho Neto demonstra claramente a dualidade estilística dos regionalistas, retratada no jogo dos discursos indireto e direto: o primeiro seguindo o estilo dos homens "cultos" e o segundo reproduzindo o vocabulário, sintaxe e aspecto fônico da linguagem do homem "rústico". Esse híbrido esquizofrênico estilístico somente fazia demonstrar o grau máximo de distanciamento entre o escritor e seus personagens, que ocupam, no texto, duas posições apartadas e distintas. Essa dualidade do discurso é alienadora e não pode ser justificada, senão por motivos puramente ideológicos. O personagem é confinado, "por meio de um ridículo patuá pseudo-realista" (CANDIDO, 2002, p. 89), no nível infra-humano dos objetos pitorescos e exóticos para o homem urbano. O discurso marcado pelo desvio da norma do homem rural previne, inclusive, que o leitor possa dialogar com os personagens, mesmo porque sequer o escritor se propôs a fazê-lo, não admitindo o homem rural verdadeiramente em seu universo ético e estético, nem se abrindo para a transformação que ele poderia causar.

Infelizmente, obras tão alienantes quanto essa freqüentemente apresentaram-se como uma recuperação do homem posto à margem, e, de fato, pode ser assim quanto à escolha temática; contudo, essa escolha deveria ser seguida de uma adequação lingüística que evitasse o tratamento alienante dos personagens. Caso contrário, o regionalismo ou outras tentativas de retratar as pessoas colocadas à margem da sociedade pode incidir em uma representação desumanizada do outro.

Por outro lado, Lopes Neto assegura uma grande identificação com o universo da cultura que pretende retratar, adotando, inclusive, o enfoque narrativo da primeira pessoa, do velho cabo Blau Nunes, que está inserido na matéria narrada. Assim, ele se esforça em atenuar ao máximo o hiato entre escritor e personagens, entre a linguagem e tema, operando uma fusão de horizontes em seu próprio discurso, que já incorporou o modo de falar de seus personagens em sua escrita, modificando sua própria visão de mundo. Dessa maneira, ele não pretende elaborar um retrato afastado de seu objeto, mas sim dialogar com um interlocutor com o qual compartilha o mundo, compartilhando também o seu modo de abordá-lo pela linguagem. Desse modo, no contato com essa visão transformada e compartilhada humaniza o leitor, provoca sua própria visão a transformar-se, incorporando também o outro, quer seja ele da elite intelectual, quer seja ele de uma classe marginalizada (CANDIDO, 2002, pp. 77-92). 
José Saramago (1922-2010) é um exemplo de literatura engajada e autêntica na análise de Leyla Perrone-Moisés (2010). Além de dedicar-se a "levantar do chão, por meio da palavra, os homens oprimidos e esquecidos por Deus pai ou pelos outros humanos mais favorecidos", ele "sempre tratou a história e a realidade com mão leve, num registro imaginário, por vezes fantástico, que levantando o leitor do chão, a este o devolvia mais lúcido". Na ocasião do falecimento do escritor, a literata escreveu (PERRONE-MOISÉS, L., 2010):

Qualquer que seja a posição dos leitores com relação às opiniões políticas do homem Saramago, ninguém pode acusá-lo de ter feito literatura partidária ou militante. $\mathrm{O}$ romancista defendeu suas idéias, não com pregação política ou lições de moral, mas por meio da melhor literatura de ficção, aquela que, nos prendendo com histórias envolventes e nos embalando numa linguagem musical, nos faz refletir sobre a história passada e a sociedade atual. Apesar da firmeza de suas idéias, em seus romances Saramago sempre tratou a história e a realidade com mão leve, num registro imaginário, por vezes fantástico, que levantando o leitor do chão, a este o devolvia mais lúcido.

\section{(...)}

Em sua evocação do passado ou em sua visão do presente, as obras de Saramago se abrem para um futuro que não seja mero destino ou fatalidade, mas que preserve os valores humanos, dentre os quais o da arte literária.

Dessa forma, o escritor autêntico deve desvendar o mundo e propô-lo como uma tarefa à generosidade do leitor. $\mathrm{O}$ escritor não pode sentir-se no mundo a menos que o supere para transformá-lo ${ }^{114}$, a menos que aja artisticamente e discursivamente. Assim, é preciso que o desvendamento-criação carregue uma vontade de transformar o mundo, e, quanto maior essa vontade, mais viva a obra será; e essa vontade de transformação traz em si a liberdade e o reconhecimento do outro. Isso sim pode ser considerado o engajamento autêntico. A justiça realizada pela literatura consiste na destruição e reconstrução do real, como pretendiam as formas primordiais de justiça, todavia, no plano da compreensão do mundo e dos projetos para ele (SOLON, 2010).

O equívoco do realismo que se propunha a simplesmente relatar, portanto, foi crer que era possível fazer do real uma pintura imparcial. Como isso seria possível se a própria percepção já é parcial?

${ }^{114}$ Transformação em configuração. 
A fuga do real, ou seu oposto, o realismo, nunca se efetuam totalmente na literatura, pois, sempre têm o real como horizonte ${ }^{115}$ e a linguagem como mediação. Se a linguagem é obstáculo no caminho do real uma vez que há algumas coisas que simplesmente não podem ser ditas, devendo ser escolhidas as palavras finitas, é também a possibilidade de fundá-lo. Tanto a fuga como o mergulho no real nos obrigam a vê-lo (PERRONEMOISÉS, L., 2006a, p. 109).

Isso não significa, contudo, que o artista criador deva se identificar a tal ponto com as aspirações e valores do seu tempo, que nelas se dissolva. Sobretudo levando-se em conta que a obra literária deve ser a priori o brado da autenticidade do artista para que seja um discurso desse indivíduo único e expresse sua alteridade, a novidade. Caso contrário, a obra literária tornar-se-ia um reflexo do impessoal, uma fala inautêntica, e perder-se-ia a identidade do criador-protótipo. Desse modo, a obra literária não é nem fruto da iniciativa individual, exclusivamente, nem de condições sociais, mas surge da confluência de ambas, indissoluvelmente ligadas.

Não somente na escrita a obra literária pode manifestar o engajamento; também a leitura pode ser engajada, mesmo porque o fenômeno literário não se limita ao primeiro momento, mas consuma-se no segundo, assim como o engajamento da literatura. Assim, se o escritor cria um mundo injusto, o leitor, ao recriá-lo tem a oportunidade de transformá-lo quando não o contempla com frieza, mas o anima com suas indignações, quando o reconhece como injusto. Dessa maneira, a dimensão ética do discurso literário aflora para e por meio da admiração e indignação do leitor.

Escritor e leitor compartilham, portanto, a responsabilidade pelo mundo que criam em colaboração e generosidade mútua. Esse mundo que não deve ser fechado, considerado e apresentado como uma massa esmagadora que pesa sobre nós, mas sim um mundo sustentado pela liberdade humana.

${ }^{115}$ A literatura nunca está afastada do real: "trabalhar o imaginário pela linguagem não é ser capturado pelo imaginário, mas capturar, através do imaginário, verdades do real que não se dão a ver fora de uma ordem simbólica" (PERRONE-MOISÉS, L., 2006a, p. 109). 
Castro Alves desponta entre os românticos como "o bardo que fulmina a escravidão e a injustiça, de cabeleira ao vento" (CANDIDO, 2006a, p. 583). De seus poemas emanam a energia de poeta humanitário. Castro Alves, o poeta dos escravos e, portanto, dos oprimidos, os amou realmente, com sentimento de justiça. E de outra forma não poderia ser, porque sua poesia era a transcendência desse sentimento do eu sobre o mundo, o resultado de uma identificação profunda entre a psicologia do poeta criador e o ritmo da vida social. Assim, por meio de sua poesia, Castro Alves revelava a si próprio e sua visão sobre os dramas do mundo. É difícil no caso de Castro Alves pôr de lado os problemas individuais e sociais que deram lastro às obras e as amarraram ao mundo vivido (CANDIDO, 2002, p. 79).

A desarmonia era resultante de lutas externas entre o homem e a sociedade, o oprimido e o opressor. Esse conflito, contudo, tomava proporções universalistas na medida em que se tratava de um episódio de um drama mais amplo: o do próprio destino humano. Assim como nas tragédias, sua poesia servia ao desencobrimento do próprio ser sob a abóbada da sociedade. A vida e espírito do poeta são um permanente agitar-se, um conflito de forças e contradições. O escravo, para ele, não é somente um caso ocasional a ser solucionado, mas o símbolo de uma questão existencial permanente, de alienação do homem de sua existência, de privação das possibilidades. A poesia de Castro Alves dialoga, então, com o mistério do destino do homem e da humanidade.

Ao mesmo tempo, sua poesia tem a força histórica do discurso, incorporando a ênfase oratória à sua magia. A retórica é um de seus recursos que opera para além da musicalidade, sendo que muitos de seus poemas denotam a incontinência verbal brasileira típica, expressando o gosto ambiente e dando à poesia poder excepcional de comunicabilidade. Todavia, a oratória em seu caso cobrou um preço, uma vez que o poeta nem sempre se contentou com a sutileza, a sugestão, a eloqüência do não dizer tão própria do discurso poético. Sobretudo no discurso humanitário ele sentiu a necessidade de ir até as últimas conseqüências, como no Epílogo do poema Lúcia, que é escancarado e pesado, exemplo do que Candido (2006a, p. 589) chama de "discurseira retumbante". Assim, para que o discurso alcance a sensibilidade de seu público, às vezes é necessário o recuo da 
própria discursividade, confiando na força encantatória e inefável do traçado poético, e na interpretação a ser construída a partir da liberdade do leitor.

Por outro lado, Castro Alves era um homem de cuja inspiração podiam surgir tiradas da maior beleza, dando ao seu discurso um toque do sublime. Deve ser dito, também, que a poesia assume um compromisso com a vida ao inserir-se em determinado tempo presente. O Navio negreiro consegue ressoar no espaço público a partir do discurso poético: “apesar de toda energia condensada nele, há uma margem inexpressa de ressonância, que precisa ser pressentida para compreendermos a sua aspiração ambiciosa" (CANDIDO, 2006a, p. 589).

É na poesia abolicionista que os aspectos positivo e negativo de sua obra atingem o grau máximo. É ela o maior expoente de sua expressão discursiva como poesia pública e privada: expressão da sociedade e do eu. O índio já havia se tornado uma das pedras de toque do orgulho patriótico brasileiro, por meio da glorificação do autóctone operada na literatura; já o negro, escravizado e misturado à vida cotidiana em posição de inferioridade, não podia facilmente ser elevado a objeto estético; sobretudo em um momento em que a arte era a expressão das elites de um Brasil idealizado e sublime. Desse modo, o abolicionismo surge como literatura de temática humanitária por excelência, sendo Castro Alves o primeiro a tratar o negro em toda a sua dimensão humana: como herói, amante; o que pode ser tomado como um ato de generosidade e de compreensão, que rompe com as barreiras sociais, psíquicas e estéticas da época ${ }^{116}$. Candido ressalta, ainda, que, para o rompimento dessa barreira, não foi necessária a penetração simpática na alma do negro, não foi necessário colocar-se em seu lugar, mas somente compartilhar um ideal de justiça pelo qual a poesia negra lutava, dialogar e entrar em acordo com o outro.

Por menos realista que fosse, a idealização do negro, pela qual o índio passara anteriormente, tornou possível a abertura da sensibilidade burguesa para a escuta da poesia e do clamor social, para o reconhecimento do negro como igual aos demais no amor, no pranto, na cólera, na ternura. Juntamente à idealização, atuou a atmosfera de dignidade lírica e a oratória; a primeira mais presente em A cachoeira de Paulo Afonso e a segunda no Navio negreiro.

\footnotetext{
${ }^{116}$ Muitas vezes os negros eram retratados fisicamente em descrições que atenuavam suas características raciais e os aproximavam dos brancos, sem qualquer toque de realismo.
} 
Evidentemente que o discurso político de Castro Alves deu-se de forma engajada, por meio de um apelo à liberdade tanto na temática quanto na forma eloqüente. Apesar de o público direto de suas obras ser a burguesia e não os escravos de quem tratava, seu esforço para que essa classe pudesse enxergar o negro com a merecida dignidade e o clamor por sua liberdade foi de extrema importância no processo de reconhecimento dessa população. Sem dúvida que o horizonte compreensivo das elites foi ampliado de forma que esta foi provocada a envolver-se na realidade opressiva e a tomar responsabilidade por ela, além de exercitar sua própria liberdade e generosidade. 


\section{O MODO DE SER DIALÓGICO DA LITERATURA}

Vendo as questões sob uma dupla perspectiva - do escritor e do público -, percebemos o movimento dialético que engloba a literatura e a sociedade num vasto sistema solidário de influências recíprocas (CANDIDO, 2006b, p. 34). A constituição do espaço político literário livre não seria possível sem o diálogo, e, portanto, sem o público, os leitores, pois é a partir de sua existência (do interlocutor) que a literatura se torna dialógica.

Conforme é discutido no segundo capítulo, a configuração da literatura enquanto representação só se consuma definitivamente na leitura e na compreensão do texto. E é nessa compreensão que se faz o diálogo, porque a única forma de compreender o texto é dialogando com ele. Evidentemente, aqui, que não se dialoga diretamente com o escritor, mas sim com o texto, uma vez que este adquire autonomia após a sua escritura que garante sua fluidez e perenidade. Por outro lado, é evidente que, quanto melhor o texto, mais expressivo do horizonte do escritor ele será. Contudo, a recriação do texto pelo leitor comporta também a exploração das possibilidades de sentido trazidas pelo texto que somente se fixarão em um sentido determinado a partir da fusão de horizontes que se opera no diálogo.

Somente na conversação, no entendimento com o outro, é que a linguagem consuma o seu autêntico ser. Todavia, o entendimento, o diálogo, assim como a literatura em si, não é uma atividade com um objetivo definido, com certa utilidade, mas antes um "processo de vida, onde se representa uma comunidade de vida" (GADAMER, 2007a, p. 575), o ser-com-o-outro intrínseco à existência humana. $\mathrm{O}$ entendimento coloca aquilo sobre o que se discorre diante dos olhos dos que participam da conversa, que passam a compartilhar a visão de um mundo. No fundo, a questão que Hannah Arendt pretende compreender e expor quando trata do discurso e da vita activa é que todas as formas de comunidade da vida humana são formas de linguagem, sendo o mundo o solo comum reconhecido por todos os interlocutores do espaço dialógico. Evidentemente que pessoas criadas em tradições diferentes vêem o mundo de maneira diferente e o articulam de forma diversa, todavia, o que se representa no discurso literário é sempre um mundo humano, isto é, estruturado na linguagem. Dessa forma, a linguagem deixa de ser mero instrumento de expressão e comunicação e torna-se o próprio ser-no-mundo-com-o-outro. Trata-se de um encontro entre dois mundos, duas visões e imagens de mundo, e não a mesma visão, acerca do mesmo mundo. É como se o princípio da verdade somente se colocasse e tivesse força 
vinculante quando o pensamento viesse acompanhado do pensamento do outro. No ponto de vista intransferível de um indivíduo espelha-se a totalidade do mundo, sendo que a multiplicidade de espelhos do universo, representada pelos indivíduos, na sua singularidade, une-se para formar o todo de um único universo (GADAMER, 2007b, p. 246).

Cada uma dessas visões do mundo está aberta à ampliação, à reiluminação e à fusão com outras concepções, tornando-se acessível a outros. Cada uma das visões de mundo que tem por base a linguagem contém potencialmente todas as demais, ou seja, pode ser ampliada pelas outras. Assim, o modo de ser literário, que é compreendido a partir de um exercício dialógico, faz da obra não meramente um ente por si subsistente, ou um ente à mão. Sua existência extrapola a mera utilidade, fazendo com que esta tome as vezes de um interlocutor, de um outro. Na literatura, em comparação com as outras artes, isso é ainda mais forte porque ela traz a presença viva de personagens, narradores e eu líricos que nos falam em primeira pessoa, como se de fato estivessem presentes a dialogar conosco. Assim, se duas pessoas estão lendo a peça de Shakespeare Hamlet, elas estão lendo o mesmo livro, ou livros distintos? Pode-se dizer que se tratam de dois livros diferentes, mas do mesmo drama, uma vez que o drama que essas pessoas lêem e a partir do qual, de certa forma, compartilham uma visão de mundo não são entes à mão, ou algum tipo de parafernália.

A leitura de um livro não representa somente o estar junto a um ente por si subsistente, mas também à presença fática do outro. Ela certamente promove o ser-com-ooutro, porque o desencobrimento do mundo é compartilhado pelo escritor e pelo leitor, mesmo ambos estando sozinhos no momento da escrita e da leitura. O comportamento do leitor é justamente o de deixar o ente advir a ele, construindo um horizonte com base em um conhecimento dialógico ao invés de monológico.

Vale ressaltar, ainda, que o diálogo da leitura não pode ser descaracterizado como diálogo com base no silêncio do escritor e do leitor, uma vez que a escuta e o silêncio são possibilidades no âmbito discursivo ${ }^{117}$. A articulação expressiva abarca mais do que o uso das palavras para dizer o que queremos, mas também a forma como usamos a linguagem, a entonação, o tempo da fala e a modulação. Assim é também com o texto escrito para ser lido ou interpretado, sendo que existem diferenças entre o uso costumeiro da linguagem e o uso que se dá no texto a por meio dele.

\footnotetext{
${ }^{117}$ O silêncio ainda é um momento da linguagem; calar-se não é ficar mudo, mas sim recusar-se a falar. Portanto, se um escritor decidiu calar-se diante de determinado aspecto do mundo, convém perguntá-lo por que decidiu passar em silêncio. Ainda, a interpretação da obra realizada pelo leitor é que a traz à fala e, portanto, o leitor também fala por meio dela.
} 
Em um primeiro momento, enquanto leitores, pressupomos que um texto traga a opinião particular de seu autor, e não a nossa, da qual podemos tomar conhecimento, sem precisar partilhá-la. Todavia, essa pressuposição não facilita em nada a compreensão, tendo em vista que é uma forma de distanciar o leitor do texto e da manter separadas e despercebidas as pré-compreensões do leitor em face do texto. Essa postura de distanciamento do texto não pode ser sustentada por muito tempo sem que se destrua o sentido do todo e tampouco se podem manter, às cegas, intactas as próprias opiniões prévias sobre o mundo quando se busca compreender a opinião de outro (GADAMER, 2007a, pp. 357-358).

Dessa forma, a literatura, como arte, provoca também a abertura do leitor para o outro, estabelecendo o fio do diálogo, na medida em que faz com que aquele se abandone e se deixe envolver pela trama das palavras. O encontro consigo mesmo propiciado por esse abandono e envolvimento passa também pela dimensão da confiança e compreensão do outro. Por conta disso, a literatura faz com que a constituição de nossa autenticidade e de nossa liberdade seja realizada por meio do reconhecimento e abertura para o outro, para o diferente. Dessa forma, para respondermos à pergunta de quem somos, precisamos estar inseridos em um contexto dialógico. O que se exige na leitura não é que se esqueçam todas as opiniões próprias, mas simplesmente a abertura para a opinião do outro, para a opinião do texto. Assim, quando conseguimos superar os preconceitos e barreiras da nossa experiência atual de mundo, ampliando-a por meio do horizonte de outrem, penetrando no universo e linguagem estranhos, isso não significa que abandonamos ou negamos nosso próprio mundo, mas voltamos a ele transformados e o transformamos. Nas palavras de Gadamer (2007a, p. 578), "como viajantes, sempre voltados para casa com novas experiências. Como andarilhos, que jamais retornam, jamais mergulharemos num total esquecimento". Desse modo, realizamos a apropriação do sentido do texto e nos apropriamos do estranho, extraindo o texto literário de sua estranheza.

Evidentemente que o texto literário, especialmente a literatura comumente dita engajada, em grande parte dos casos fala a uma situação determinada, em que a opinião pública e os preconceitos já são previstos. Em contrapartida, quando a literatura extrapola aquele contexto, a compreensão não é prejudicada, uma vez que o hiato entre o contexto original do texto e o atual é uma condição da própria interpretação. Assim, aquele que procura compreender está sempre pautado pelo texto a ser compreendido, ele deve estar disposto a deixar que este lhe diga alguma coisa. Por isso, a consciência hermenêutica, de 
compreensão de um texto literário, deve mostrar-se receptiva à alteridade do texto, exercitando também a compreensão da própria alteridade e pluralidade. Todavia, para que essa compreensão seja autêntica e livre, não se pressupõe nenhuma anulação do leitor, apenas a apropriação de si próprio e a tomada de consciência de sua identidade e de suas opiniões prévias.

Dessa forma se opera a fusão de horizontes da visão de mundo prévia do leitor com a visão de mundo trazida pela obra literária, como um diálogo, uma transformação e apropriação. Em princípio, a atividade da leitura assemelha-se um pouco à formação teórica, segundo a qual comportar-se teoricamente já é, como tal, um alheamento, ou seja, uma exigência de se ocupar com o não-imediato, com algo de natureza estranha, que pertence à memória e ao pensamento (GADAMER, 2007a, p. 49). Apesar de a vida determinar-se pelo fato de o ser vivo distinguir-se do mundo em que vive, sua autoconservação tem por princípio o nutrir-se do que lhe é alheio, de modo que este integra em si o estranho. Sua situação fundamental, portanto, é a assimilação. A distinção torna-se, portanto, uma não-distinção. (GADAMER, 2007a, p. 339)

Desse modo, o dar-se conta da vida e de si significa, em última instância, compreender e incorporar o outro, transformando-se por ele. Disso decorre uma conclusão: somente a partir da abertura para o outro e de seu reconhecimento é que podemos pensar a igualdade, o reconhecimento do diferente como semelhante. Contudo, o reconhecimento aqui proposto não é de um conhecimento dominador, mas, partindo da generosidade e da fusão de horizontes, possibilita que o outro compartilhe o seu mundo e sua liberdade conosco e vice versa. O que ocorre no diálogo, fundamentalmente, é esse compartilhamento de visões de mundo, sendo todas elas verdadeiras e completas.

Desse ponto de vista, a linguagem não é um conjunto de sinais, mas sim um meio de expressão pelo qual compartilhamos o mundo com o outro; seria o tabuleiro (medium) no qual se dá o acordo e o entendimento entre os interlocutores. Por conta disso que o colocar-se no lugar do outro não constitui um verdadeiro diálogo, tendo em vista que o único propósito seria conhecê-lo, mas sem se abrir para que a visão dele penetre também em nosso mundo. No diálogo não se procura meramente o entendimento sobre um tema, sobre a opinião do outro, por meio da descoberta de sua posição e horizonte, uma vez que, para tanto, não precisamos nos entender com o interlocutor. Antes, no diálogo, estamos sujeitos à transformação de nosso próprio horizonte pelo outro e à constituição de uma imagem comum. Nas palavras de Gadamer (2007a, p. 401): 
(...) aquele que procura compreender se coloca a si mesmo fora da situação do entendimento. Ele próprio não é atingível. Na medida em que se inclui de antemão também o ponto de partida do outro naquilo que ele procura nos dizer, estamos colocando nosso próprio ponto de partida na segurança de não poder ser atingido. (...) Este reconhecimento da alteridade do outro, que a converte em objeto de conhecimento objetivo, é, no fundo, uma suspensão de nossa própria pretensão.

A pretensão de que trata Gadamer é a pretensão de encontrar uma verdade compreensível que possa ser válida para nós mesmos, e para o nosso encontro conosco mesmos. É a partir da descoberta dessa verdade que deve travar-se o reconhecimento do outro e das diferenças; em um diálogo que trace um horizonte comum, em que haja uma ascensão do eu e do outro a uma universalidade transcendente tanto à nossa própria particularidade quanto à do outro. Nesse caso, nenhuma das duas partes submete-se ao conhecimento da outra $^{118}$, e tornamo-nos conscientes da alteridade e até da individualidade irredutível do outro.

Assim, quando se lê um texto literário não nos deslocamos até a constituição psíquica do autor, uma vez que nos movemos em uma dimensão de sentido que é compreensível em si mesma, participando-se em um sentido comum e em uma verdade comum. Todavia, o que é interessante é que essa verdade comum expressa pelo sentido extraído do texto não é imposta pelo autor ou pelo leitor; ela parte de uma representação originária do autor, da perspectiva que levou o autor a fazer aquela representação, para se consumar na interpretação produtiva do leitor ${ }^{119}$, que sempre parte de sua base de expectativas de sentido extraídas de sua relação precedente com o assunto.

Visto que o deslocamento à constituição psíquica do autor não é adequado à compreensão literária, temos uma forma de ser com o outro, que parte da participação em um sentido comum, que não é física. Essa forma de participação não se assemelha à forma como estamos junto aos entes por si subsistentes, mas é extremamente intensa e comprova como se pode ser-com-o-outro, compartilhar o mundo, mesmo na distância e, no limite, na solidão.

Quando falamos de compartilhamento e de fusão de horizontes no diálogo literário, tratamos de uma forma especial de ser com o outro. No ato de leitura mais ingênuo essa

\footnotetext{
${ }^{118}$ É evidente que a situação e perspectiva do outro estão em jogo, todavia, não sob o domínio de nosso conhecimento unilateral.

${ }^{119} \mathrm{O}$ sentido de um texto supera seu autor e o aspecto ocasional representado pelo autor e seu público originário não eventualmente, mas sempre. Por isso, a compreensão nunca é um comportamento meramente reprodutivo, mas também sempre produtivo de sentido (GADAMER, 2007a, p. 392)
} 
fusão é mais inextricável, uma vez que o leitor não chega a distinguir o próprio mundo do que é do outro. Na literatura isso é muito presente, uma vez que o envolvimento do leitor com o texto é imenso, assim como o abandono de si próprio.

Com isso, a compreensão do texto dá-se a partir de uma relação do leitor com o texto análoga à conversação. Todavia, como não nos deslocamos à constituição psíquica do autor, o texto não nos fala como faria um tu em um diálogo. O significado do texto deve ser extraído da fala do texto, que trazemos à vida a partir de nós mesmos. Evidentemente que não se trata de uma intervenção arbitrária nas palavras do texto, uma vez que a obra carrega respostas latentes às perguntas que realizamos. No momento em que travamos essa dialética da pergunta e da resposta no âmbito da leitura, estamos a dialogar com o texto.

O diálogo com o texto, especialmente o literário, não se dá de uma forma clara. Não se tem consciência de estar dialogando, inquirindo a obra. A situação hermenêutica frente ao texto literário, portanto, não é idêntica à que se dá entre duas pessoas. Sendo o parceiro da conversação hermenêutica o texto, este somente pode falar por intermédio do leitor e intérprete:

Somente por ele os signos escritos se reconvertem novamente em sentido. Ao mesmo tempo, em virtude dessa recondução à compreensão, o próprio tema de que fala o texto vem à linguagem. Assim como acontece nas conversações reais, é o tema comum que une as partes entre si, nesse caso o texto e o intérprete.

\section{(...)}

Mas isso significa que, no redespertar o sentido do texto já se encontram sempre implicados os pensamentos próprios do intérprete. Nesse sentido, o próprio horizonte do intérprete é determinante, mas também ele não como um ponto de vista próprio que se mantém ou se impõe, mas como uma opinião e possibilidade que se aciona e coloca em jogo e que ajuda a apropriar-se verdadeiramente do que diz o texto (GADAMER, 2007a, p. 502).

No texto literário, a conversação com o texto se dá de forma ainda mais peculiar, sendo que o diálogo ocorre muito mais na forma de envolvimento na trama literária, como se esta fosse uma experiência própria do leitor, o que de fato é. Assim, dialoga-se com os personagens, com o eu-lírico do poema, com o narrador. A compreensão ocorre no âmbito dessa nova realidade criada pelo autor e recriada pelo leitor e pelo intérprete, na medida em que todos esses partícipes do fenômeno literário, que participam da realização da literatura no seu autêntico modo de ser, passam a compartilhar um mundo. Nada mais adequado para 
o reconhecimento do outro nos direitos humanos do que a construção de um mundo compartilhado, não a despeito da diversidade, mas a partir dela.

Evidentemente que o autor não desaparece completamente da cena da leitura: a sua representação é que é trazida à fala; todavia a compreensão se dá em um jogo com múltiplos participantes e instâncias, cada qual recriando o texto com base no diálogo, que tem a linguagem e o texto como tabuleiro de encontro dos horizontes. Segundo Antonio Candido (2006b, pp. 47-48), "na medida em que a arte é um sistema de comunicação interhumana, ela pressupõe o jogo permanente de relações entre os três [autor, obra e público], que formam uma tríade indissolúvel”.

Como vimos, o público (leitor) é o que dá sentido e realidade à obra, sendo que o autor dele depende para consumar sua expressão. Os artistas incompreendidos ou desconhecidos em seu tempo passam realmente a viver quando a posteridade define qual o seu valor. Desse modo "o público é fator de ligação entre o autor e a sua própria obra" (CANDIDO, 2006b, p. 48). A obra, por seu turno, é o que vincula ao autor o leitor, uma vez que este só estende seu interesse à personalidade daquele após tomar contato indispensável com sua obra. O autor, por fim, é o que desencadeia todo o processo, o que faz surgir algo novo e exerce a capacidade humana de criar e atuar no espaço público.

Assim como toda conversação, também a leitura pressupõe uma linguagem comum, alguma coisa interposta entre os interlocutores sobre a qual ambos alternam-se, como em um tabuleiro $^{120}$. Todavia, a linguagem comum da compreensão não se trata de algo posto à disposição do leitor, mas sim de algo construído no processo da fusão de horizontes, como um acordo. Nas palavras de Gadamer (2007a, p. 493), "à medida que consegue dar-se a conversação, ambos se submetem à verdade do assunto em questão, que os une em uma nova comunidade." O acordo da compreensão é algo que se realiza em nós e nos transforma, surgindo naquele momento. Dessa maneira, toda verdadeira conversação implica nossa reação frente ao outro, implica deixar realmente espaço para seus pontos de vista e colocarse no seu lugar, não no sentido de querer compreendê-lo em sua individualidade, mas compreender aquilo que ele diz. O pressuposto para que compreendamos a visão de mundo do outro, trazida pelo texto literário, e, portanto, para o acordo, é que estejamos dispostos a isso, acolhendo o estranho e o adverso com generosidade.

\footnotetext{
${ }^{120}$ Todo processo da compreensão e do acordo é um processo de linguagem, uma vez que a linguagem é o meio universal em que se realizam o acordo dos interlocutores e o entendimento sobre a coisa em questão. $\mathrm{O}$ problema hermenêutico não é, pois, um problema de domínio correto da língua, mas de correto acordo sobre um assunto, que se dá no medium da linguagem.
} 
Todavia, existe uma situação específica em que a produção do acordo entre leitor e escritor é complicada, justamente porque existe um desacordo prévio na linguagem: a situação na qual uma conversa é realizada entre interlocutores que não falam a mesma língua. Não nos enganemos com relação à linguagem, pressupondo que esta se trata de um mero instrumento, que deve ser adaptado para que ambos os interlocutores possam utilizálo. Muito pelo contrário, a linguagem contém a própria visão de mundo dos interlocutores e constitui a principal forma de desencobrimento do mundo de que o homem dispõe. Assim, compreender um texto em uma língua diferente da nossa, significa não só extrair o significado das palavras, mas a transposição daquela visão de mundo para a nossa própria. O fato de um texto literário estar em uma língua estrangeira somente agrava a dificuldade hermenêutica, agrava a estranheza do texto e, portanto, representa um desafio ainda maior para a compreensão daquilo que se nos apresenta. Contudo, sendo essa dificuldade superada, o ganho em relação à compreensão e ao reconhecimento do outro é ainda maior. O leitor que se aprofunda numa literatura estrangeira mantém, a todo tempo, a liberdade de voltar novamente a si mesmo, e assim está ao mesmo tempo aqui e acolá. Evidentemente que o voltar a si mesmo é sempre um voltar a si mesmo transformado e que não há o movimento do ir e vir: os seres humanos já estão sempre projetados para o outro.

Desse modo, considerando a fluidez da literatura e a escala espaço-temporal bastante ampla que ela percorre, não podemos deixar de considerar uma figura intermediária, que torna possível que o espaço dialógico e os interlocutores sejam ampliados: a figura do tradutor. A tradução demanda a compreensão do texto pelo tradutor e interpõe uma etapa, também dialógica - uma mediação expressa - entre escritor e leitor no intuito de se criar uma linguagem comum a ambos. Evidentemente que existe uma distância insuperável entre a literalidade originária da obra e a tradução, motivo pelo qual o tradutor deve ser hábil na transposição do sentido a ser compreendido para o contexto lingüístico em que vive o outro interlocutor ${ }^{121}$. Por conseguinte, apesar de a tradução reduplicar o problema hermenêutico, ela é necessária para que um diálogo mais universal ocorra, ampliando o espaço público de que faláramos ${ }^{122}$.

\footnotetext{
${ }^{121}$ De certo que quem foi criado numa determinada tradição cultural e de linguagem vê o mundo de maneira diferente daquele que pertence a outras tradições. Todavia, o que se representa na literatura é sempre um mundo humano, estruturado na linguagem.

${ }^{122}$ Assim, quando a tradução é necessária, é porque não há outra forma de o leitor compreender o texto por si só. O acordo não se processa entre os companheiros de diálogo (autor e leitor), mas sim entre dois intérpretes: tradutor e leitor. Onde há acordo entre leitor e escritor, não se traduz, mas se fala; a palavra falada é desvelada e vem à fala de pronto.
} 
Heidegger (2008c, p. 28) chama a atenção para o fato de que inicialmente apreendemos o processo da tradução como algo externo, técnico-filológico. Entretanto, temos dificuldade de entender que, constantemente, já estamos traduzindo nossa própria língua, a língua materna, para sua palavra própria. Em cada diálogo ou monólogo vige um traduzir originário: a escolha de palavras já é um resultado da transposição para nossa visão de mundo, para verdade e clareza próprias. A respeito da tradução de nós mesmos escreve Ferreira Gullar:

Traduzir-se

Uma parte de mim é todo mundo: outra parte é ninguém: fundo sem fundo.

Uma parte de mim é multidão: outra parte estranheza e solidão.

Uma parte de mim pesa, pondera: outra parte delira.

Uma parte de mim almoça e janta: outra parte se espanta.

Uma parte de mim é permanente: outra parte se sabe de repente.

Uma parte de mim é só vertigem: outra parte, linguagem.

Traduzir uma parte na outra parte — que é uma questão de vida ou morte será arte?

(GULLAR, 2004) 
Assim é que a compreensão de nós mesmos, a transposição de nossos próprios desígnios para nossos atos e palavras, é arte e é tradução. No texto, em sua compreensão mais corriqueira, esse transpor realiza-se sem que o idioma se altere. Cada escritor produz sua obra em sua própria palavra, singular, obrigando-nos a perceber essa palavra como se fosse a primeira vez que a ouvíssemos.

No século XVIII, sob a égide da universalidade da razão que condicionaria, inclusive, a linguagem, preconizava-se a tradução como operação de transcodificação, voltada somente à adequação de um pensamento às peculiaridades formais que caracterizam cada língua nacional (AZENHA JUNIOR, 2006). Entretanto, já nesse mesmo século, a tradução das metáforas denunciava, contudo, que a tradução extrapola as peculiaridades meramente formais e adentra o campo da interpretação, apontando para redes associativas estabelecidas de forma diferente entre as linguagens envolvidas no processo. Isso coloca em dúvida a estabilidade de uma noção linguagem associada à universalidade da razão e ao modo, não coincidente, como cada povo enxerga e interpreta o mundo.

Johann Gottfried von Herder (1744-1803) é que lança definitivamente as bases para que o paradigma racionalista da linguagem seja revertido. Para ele, a diversidade é característica intrínseca da linguagem, evidenciada no uso lingüístico condicionado por diferentes situações e, principalmente, na tradução. A linguagem não seria, portanto, matéria estável, mas um ente em movimento de ser, que se transforma.

É importante lembrar algumas considerações de Goethe em Notas ao divã, que são muito úteis ainda hoje para a compreensão de questões ligadas ao intercâmbio de línguas e culturas.

Quando o autor original da obra depara-se com uma boa tradução, a obra que tem diante de si é sua e, ao mesmo tempo, não é. O autor original irá surpreender-se com a vida própria que sua obra adquiriu em outra língua. Essa é a impressão de Goethe ao deparar-se com a tradução para o latim de sua obra Hermano e Dorotéia. Ele descreve a tradução como um espelho, que possui a capacidade de irradiar uma força própria e mágica, que condensava o idêntico e o modificado, vendo confirmadas suas próprias pretensões. $\mathrm{O}$ poeta não nega, portanto, a autonomia ao texto traduzido, ao contrário de avaliações negativas da tradução como obra de segunda mão (AZENHA JUNIOR, 2006).

Para que a tradução possa realizar essa mediação com excelência e autenticidade, o sentido que o texto possui na linguagem original precisa ser mantido; a transposição da 
palavra deve nos colocar no âmbito e no modo da experiência a partir da qual a cultura originária fala a palavra. Mas como esse sentido deve ser compreendido por falantes de outra língua, em outro universo lingüístico, ganha validez de outra forma. Assim, a tradução consiste em atividade hermenêutica pura, e seu produto é o resultado da interpretação que o tradutor deu à palavra que lhe foi proposta (GADAMER, 2007a, p. 498). Desse modo, projeta-se no texto uma nova luz, procedente da nova língua e destinada ao leitor da mesma. Assim como toda interpretação, a tradução é uma recriação, uma reiluminação.

A leitura diretamente em línguas estrangeiras depende do conhecimento que se possui dessa língua, mas, quando pode ser realizada, amplia e enriquece o mundo do leitor por meio do universo da língua estrangeira. O desafio do tradutor, portanto, é trazer a literatura estrangeira para o entendimento do leitor que não compreende aquela língua. Todavia, é melhor que essa intermediação seja realizada conservando-se o impacto e o estranhamento que aquele mundo estranho possui. Caso contrário, a visão do outro fica empobrecida e reduzida, perde o que lhe é próprio e transformador.

O traduzir, portanto, é um dos recursos que garante a continuidade da vida de uma obra. A tradução estabelece um fluxo que rompe também as barreiras do tempo, podendo a obra ser traduzida em línguas antigas, como o latim, e nas línguas a porvir. O fluxo da tradução cria, portanto, a possibilidade de muitas realizações.

Como falamos em certo momento do segundo capítulo, a literatura, como arte, alcança sua plenitude em sua transformação em configuração, isto é, no jogo do diálogo entre leitor e escritor, por meio da obra. $\mathrm{O}$ ato do escritor nesse jogo é um ato de generosidade para com seu leitor, uma vez que ele precisa trabalhar seu texto tendo em vista o conjunto da obra que deverá ser compreendido pelo público. É evidente que isso não quer dizer que o escritor não poderá experimentar o sentido do todo de sua obra, em que ele, representando, desempenha o seu papel. Nas palavras de Gadamer (2007a, p. 164), isso significa que o "espectador tem somente uma primazia metodológica: pelo fato de o jogo ser realizado para ele, torna-se patente que possui um conteúdo de sentido que deve ser entendido". Quando existe, além dos jogadores autor e leitor, o intérprete, que exerce o papel do intermediário, o jogo continua a existir; porém, mais um jogador entra em cena e deve voltar a sua interpretação da obra para o leitor ou espectador. O intérprete pode ser considerado desde o ator de teatro, o orador de um texto, até o tradutor de uma obra.

Em relação ao leitor, o seu papel, o seu modo de ser é definido pela atividade da leitura, da assistência, que extrapola um mero estar ali concomitantemente à obra, mas 
implica o participar verdadeiro, muito além da mera relação subjetiva com o objeto (GADAMER, 2007a, p. 181). Isso porque ler, assistir, é uma forma de estar-fora-de-si, de esquecer a si próprio e projetar-se para o outro, transcendendo a si próprio. Desse modo, a privatividade é superada por um ato de entrega e de liberdade, que constitui a contribuição positiva do espectador que se abre para deixar o ente advir a ele.

Contudo, como se ressaltou no segundo capítulo, o auto-esquecimento do leitor corresponde, na realidade, a uma continuidade dele consigo próprio. A distância que ele toma de seu próprio mundo é que permite a sua abertura para a compreensão da representação e para a construção do significado da obra. Assim, o leitor, que participa de certa forma da construção de sentido da obra literária, é um momento daquilo que denominamos o estético: assim, “a reconversão de um traço morto em sentido vivo, só se dá ao ser compreendido" (GADAMER, 2007a, p. 230).

A partir do diálogo, a literatura ascende tanto escritor quanto leitor a uma universalidade: a universalidade da qual ela própria participa. 


\section{A INCAPACIDADE PARA O DIÁlOGO E $O$ TÚNEL}

A incapacidade para o diálogo, que se traduz na falta de abertura para o outro e de generosidade, é algo que tem contribuído fortemente para o não reconhecimento do outro, do diferente, como parte da mesma categoria humana que auferimos a nós mesmos. Assim sendo, a esse outro também não são outorgados os mesmos direitos humanos que reivindicamos e pretendemos efetivar para nós mesmos.

A monologização crescente acompanha o modo de pensar técnico-científico, o discurso científico que cada vez mais se afasta do poético. O comportamento científico estimula uma auto-alienação, um discurso voltado para o domínio do outro, anterior à sua aceitação e à escuta mútua. Todavia, essa auto-alienação implica a recusa ao entendimento verdadeiro, e a aceitação do pseudo-entendimento presente na vida pública em geral.

Ernesto Sabato (1911-) (2004, pp. 149-151), físico que conseguiu ir muito além do discurso enunciativo, elaborou uma metáfora, em seu romance El túnel, da solidão gerada pela não predisposição ao diálogo, pelo fechamento para o outro, e pela impressão irreal de se estar conhecendo o outro:

E foi como se os dois estivéssemos vivendo em caminhos ou túneis paralelos, sem saber que estávamos um ao lado do outro, como almas semelhantes em tempos semelhantes, para nos encontrarmos no fim desses caminhos, diante de uma cena pintada por mim como a chave destinada somente a ela, como um sinal secreto de que eu já estava ali e as passagens, por fim, haviam se unido e a hora do encontro havia chegado.

A hora do encontro havia chegado! Mas, realmente os (nossos) caminhos se uniram e nossas almas realmente se comunicaram? Que ilusão estúpida foi tudo isso! Não, os caminhos seguiam paralelos como antes, ainda que agora o muro que os separava era como de vidro e eu podia ver a Maria como uma figura silenciosa e intocável... Não, nem sequer esse muro era sempre assim: às vezes voltava a ser de pedra negra e nesses momentos eu não sabia o que se passava do outro lado, o que era dela nesses intervalos anônimos, que estranhos acontecimentos aconteciam; eu até pensava que nesses momentos seu rosto mudava e que uma careta o deformava e que talvez houvesse risos trocados com outro e que toda a história dos caminhos (que se encontram) era uma ridícula invenção ou crença minha e que em toda a história só havia um único túnel, escuro e solitário: o meu, o túnel em que eu passei minha infância, minha juventude e toda a minha vida. (...) $E$ então sentia que meu destino era infinitamente mais solitário do que eu imaginara (tradução livre) (sem grifos no original). 
A capacidade para o diálogo, que deveria ser um atributo essencial do homem, tem sido subvertida em uma recusa do outro, na recusa de sermos também transformados pelo encontro com o outro, ao invés de apenas transformá-lo impondo nossa cultura e opinião. A literatura aparece nesse cenário, como um resgate, um exercício dessa capacidade elementar de comunicação, de construção de um horizonte e de uma verdade comum.

A literatura autêntica não somente propicia a espontaneidade do discurso, como realiza um apelo à liberdade do escritor e do leitor. Liberdade esta exercida na troca hermenêutica, no diálogo da leitura e da interpretação. E à medida que o escritor exercita sua liberdade, ele a exerce, ele se abre generosamente ao leitor, que também aceita ser transformado por aquela leitura. E assim dever-se-ia operar todo o verdadeiro discurso, toda a autêntica política e liberdade. Na liberdade discursiva que atravessa a liberdade de outrem, e somente é válida a partir dela.

Porém, a incapacidade para o diálogo não se reconhece como tal e necessita de uma forma sutil de sensibilização, de quebra das barreiras da autêntica comunicação e aceitação. 
Capítulo IV

A Literatura no Tempo 
O que se foi

$\mathrm{O}$ que se foi se foi.

Se algo ainda perdura

é só a amarga marca

na paisagem escura.

Se o que se foi regressa, traz um erro fatal: falta-lhe simplesmente ser real.

Portanto, o que se foi, se volta, é feito morte.

Então por que me faz o coração bater tão forte?

(GULLAR, 2010, p. 45)

A idéia de Heidegger de que o passado caminha à nossa frente indica um caminho para a possibilidade de projetar o futuro de forma livre e autêntica: o caminho da compreensão e significação do passado que nos precede. Para Heidegger, estar atento ao ser significa estar atento à mobilidade e ao tempo. Por conseguinte, as raízes da liberdade devem ser buscadas na tradição que fala por meio de nós e no entendimento que temos dela. A nossa relação com o atual é marcada pelo fato de nos encontrarmos, simultaneamente, sob o potente eco de nossa origem. Essa origem não só é nosso presente como também nossa própria história, senão, toda a vida e atividade humana. E não é certo que principalmente a arte é capaz de nos mostrar o que permanece? (GADAMER, 1993, p. 143).

De acordo com Werner Jaeger (1986, pp. 6-7), vivemos um momento histórico em que a vida humana encolheu-se na rigidez de sua carapaça, necessitando o homem mergulhar "nas camadas profundas do ser histórico"123. De fato, o mistério e alumbramento originários cercam as primeiras criações de estímulos de eterna renovação,

${ }^{123} \mathrm{O}$ que, para Jaeger, significa um debruçar-se sobre o espírito grego, que seria estreitamente vinculado ao nosso, dando forma à vida palpitante que em nossos dias se mantém com dificuldade. 
sendo o resgate do ser histórico um movimento de repetição renovadora. A literatura possibilita, portanto, o contato com a tradição através da renovação do impulso original por meio de outro impulso criador.

Assim, no bojo da discussão que opõe o engajamento ativo nas coisas deste mundo e o pensamento puro que culmina na contemplação ${ }^{124}$, sendo que essas duas "atividades" correspondem a preocupações humanas inteiramente diferentes, Arendt ilustra tal dicotomia com a diferença entre a imortalidade e a eternidade. A imortalidade coloca-se dentro da linha temporal, como continuidade no tempo, vida sem morte nesta terra e nesse mundo, ao passo que a eternidade está fora da linha temporal, além dela, transcendendo o tempo, a vida e o universo (ARENDT, 2001, pp. 26-30), servindo para a caracterização da atemporalidade de um Deus transcendente. Sobre o tempo poetiza Ferreira Gullar (2010, p. 82):

O tempo cósmico ente minúsculo num braço da galáxia, ouço dizer que ela demora 250 milhões de anos para fazer um giro completo em torno de seu eixo

e penso: o homem existe há pouco mais de 100 mil anos é como se o giro da galáxia jamais de completasse

é como se ela não girasse e que o diria esta mosca - que na toalha da mesa pousa agoracuja existência talvez dure pouco mais de uma hora?

\footnotetext{
${ }^{124}$ A vita contemplativa dos antigos tem como pressuposto um conceito abstrato e anti-histórico, que considera o espírito uma região de verdade e de beleza eternas, acima das vicissitudes dos povos (JAEGER, 1986, p. 11).
} 
Inserida em um cosmo, no tempo cósmico, onde tudo era imortal, a mortalidade tornou-se o emblema da existência humana, até mesmo em relação aos animais, que podem ser considerados imortais, uma vez que sua vida imortal é garantida pela procriação da espécie indiferenciada da qual são membros. Cada ser humano, contudo, é único e mortal. A vida individual é identificável e difere das outras desde o nascimento até a morte. Possui um curso retilíneo que intercepta o curso imortal e cíclico da vida biológica das espécies.

A finitude humana implica, também, sua relação com a essência da verdade, que não pode ser conhecida como um ente eterno a conheceria, tendo em vista que "não somente a essência da verdade, mas de cada coisa essencial tem, cada vez, sua própria riqueza, a partir da qual uma época histórica pode colher somente uma pequena parte de sua porção de cada vez" (HEIDEGGER, 2008c, p. 26). A história nada mais é do que a transformação da forma como os homens relacionam-se com a verdade, concebem sua essência. Os entes históricos e temporais, como os seres humanos, recebem seu ser dessa transformação, e a história é, portanto, a história do destino do ser, o movimento de encobrimento e desencobrimento do ser que advém aos seres humanos. Se existe algo de imperecível na existência humana é o sentido universal do destino e da verdade do ser.

Entretanto, aos mortais é atribuída uma função e uma dádiva que seria a capacidade de produzir obras, feitos e palavras, que mereceriam pertencer à eternidade e, pelo menos até certo ponto, pertencem à imortalidade. Por meio dessas obras, os homens alcançam certo tipo próprio de imortalidade, deixando vestígios imorredouros; em contraposição aos animais que se satisfazem com os prazeres que a natureza lhes oferece, vivem e morrem dessa mesma forma (ARENDT, 2001, pp. 26-30). Ora, não seria esse conceito de imortalidade "própria do homem" através de uma obra, o trazido pela função total da obra literária descrita por Antonio Candido?

Segundo Antonio Candido, a função total da literatura seria a mais importante para se determinar a relevância de uma obra. De fato, o que ele denomina função total extrapola a finalidade ideológica da obra pretendida pelo autor e não pode ser determinada no momento da criação e a partir do primeiro contato com o público. A dimensão total ${ }^{125} \mathrm{de}$

\footnotetext{
${ }^{125}$ Um dos exemplos mais claros de desempenho pleno da função total da literatura é a épica homérica, que, além de exercer um papel fundamental na formação dos povos gregos e no desvelamento da verdade do ser, constituiu uma ação ampla e permanente. A influência da épica homérica estendeu-se, sem interrupção, por milhares de anos, ao passo que épica medieval não teve sua ação estendida com muita ênfase ao longo da história. A divina comédia, de Dante, foge a esta lógica e possui um papel análogo à poesia homérica. Tanto na vida de sua própria nação quanto de toda a humanidade. Não à toa, que o poema de Dante traz também a discussão existencial e do destino humano em sua estrutura (JAEGER, 1986, pp. 45-46).
} 
uma obra literária só pode ser percebida depois de longo tempo, porque só então é possível compreender o conteúdo humano e humanizador que ela conserva e dissemina.

Mesmo porque, a princípio, a transformação em configuração da arte liberta-a da representatividade do jogador e a constitui no puro fenômeno daquilo que eles jogam (representam). Como tal, a arte é, por princípio, repetível e, por isso mesmo, duradoura (GADAMER, 2007a, p. 165). Todavia, somente o tempo dirá se ela de fato alcançou a transcendência à tradição, ou não. Uma particularidade da criação literária, que a diferencia de outras formas de manifestação artística, seria sua capacidade de disseminação e sobrevivência: relativamente adaptável às transformações tecnológicas e livre de seu lócus originário, ela percorre o tempo e o espaço com fluidez.

No conto de Borges $O$ imortal, ele descreve uma cidade de imortais cuja construção é nefanda e desesperadora por não guardar qualquer significado, sendo interminável, atroz e complexamente insensata. $\mathrm{O}$ visitante de tal cidade chega até mesmo a especular que tivesse sido edificada por deuses eternos. A explicação é que sua fundação teria marcado uma etapa em que, julgando vã qualquer obra, os imortais determinaram viver no pensamento, na pura especulação.

Não se admira que os imortais, passados infindáveis séculos, tivessem chegado à conclusão da irrelevância de suas obras, tendo em vista que poderiam reproduzir seus pensamentos em eterna repetição, quantas vezes se fizesse necessário. Sem contar que os homens imortais seriam indistintos, por um motivo deveras simples: “(...) em um prazo infinito ocorrem a todo homem todas as coisas. Por suas passadas ou futuras virtudes, todo homem é credor de toda bondade, mas também de toda traição, por suas infâmias do passado ou do futuro. (...) Ninguém é alguém, um só homem imortal é todos os homens" (BORGES, 2001, p. 28). Tal fenômeno não ocorre com os seres mortais, que possuem uma finitude intrínseca, determinante de sua existência. Assim escreve Borges (2001, p. 29):

A morte (ou sua alusão) torna preciosos e patéticos os homens. Estes comovem por sua condição de fantasmas; cada ato que executam pode ser o último; não há rosto que não esteja por dissolver-se como o rosto de um sonho. Tudo, entre os mortais, tem o valor do irrecuperável e do inditoso. Entre os imortais, ao contrário, cada ato (e cada pensamento) é o eco de outros que no passado o antecederam, sem princípio visível, ou fiel presságio de outros que no futuro se repetirão até a vertigem. Não há coisa que não esteja como que perdida entre infatigáveis espelhos. Nada pode ocorrer uma só vez, nada é preciosamente precário (sem grifos no original). 
Desse modo, a permanência para a qual tende a literatura é uma das formas de liberdade frente ao mundo circundante e frente à própria existência humana, tornando possível a transcendência do imediatismo da existência, bem como a transcendência pela obra da situação existencial em que ela foi criada. O ente pode até falecer, mas a memória de seu ser perdura. Assim, tanto o belo quanto o acontecer hermenêutico, que se conjugam na experiência literária, pressupõem a finitude da existência e do espírito humanos. Um espírito infinito não poderia experimentar o belo como experimentamos, tendo em vista que não poderia ver além da beleza do todo, do Aleph (GADAMER, 2007a, p. 626).

Contudo, o que havemos de refletir com relação à memória e à tradição proporcionadas pelo encontro com a literatura é como o homem pode enxergar o seu próprio sentido e encontrar sua própria determinação pela história; que é a história da transformação da relação do homem com o ser e com a verdade. O que as visões modernas da história, desde o século XIX, vêm distorcendo, tendo em vista que almejam, de forma pretensiosa, "emprestar" à história um "sentido" através de balanços historiográficos; como se a "história em si" fosse sem sentido.

Antonio Candido (2006a, p. 31) possui a convicção de que o ponto de vista histórico é um modo legítimo de estudar literatura, pressupondo que as obras se articulam no tempo. No entanto, entende que um equívoco no que se entende por histórico tem sido cometido: "um esteticismo mal compreendido procurou, nos últimos decênios, negar validade a esta proposição - o que em parte se explica como réplica aos exageros do velho método histórico, que reduziu a literatura a episódio da investigação sobre a sociedade, ao tomar indevidamente as obras como meros documentos."

A história, portanto, é fruto da própria temporalidade do $\mathrm{ser}$ do homem e a literatura é ente e ser fruto de sua criação. Conforme nossas reflexões anteriores, somente a finitude humana tornaria possível a literatura, o que faz dela temporal. Somente pela finitude humana é possível também a história e o que se chama de tradição, tendo em vista que somente a efemeridade da existência faz a transformação e renovação possíveis, bem como o esquecimento ${ }^{126}$ do ser, "mas o que o homem pode em relação à história é estar

\footnotetext{
${ }^{126}$ A obliteração, o esquecimento, é um encobrimento que subtrai algo essencial e aliena o próprio homem a si mesmo, isto é, o faz estranho à possibilidade de morar em sua essência. Para Heidegger, as palavras herdadas por nós pelos gregos mereceriam uma interpretação mais originária de seus significados. A palavra "esquecer", em grego $\lambda \alpha v \theta \alpha \nu o \mu \alpha$, perde sua essência em sua tradução moderna. Em seu significado original é trazida como uma espécie de ocultamento, no qual o ente está submerso no velamento de tal modo que neste velamento do ente permaneço velado de mim mesmo. Essa é a essência do esquecer, oposta, portanto, mais fundamentalmente à essência da verdade, $\alpha \lambda \eta \theta \varepsilon ı \alpha$, que é desencobrimento (HEIDEGGER, 2008c, pp. 106-108).
} 
atento e cuidar de tal modo que a história não encubra e não recuse ao homem o seu sentido" (HEIDEGGER, 2008c, p. 87).

Ora, é inerente à história e à tradição transformar-se, mas nem por isso podem ou devem ser esquecidas ou rejeitadas. O que resta, ainda, é que o modo de andar "prenhe de morte" na abóbada essencial da história não esgota a "marca" e a "viagem", isto é, o ser do homem como tal. Talvez uma das formas de interpretar essa idéia trazida da Politéia (cf. X, 617 d 7) não seja a da permanência do ser por meio da alma, mas a perenidade do ser na medida em que este é emprestado à arte e à literatura e sobrevive sempre renovado por meio dela e de seus leitores e intérpretes. 


\section{TEMPORALIDADE DA ARTE E DA Literatura}

Assim, nos deparamos com a tarefa de uma interpretação temporal da obra de arte. Em geral essa simultaneidade, essa presença do ser estético, nós denominamos de atemporalidade. A princípio, a atemporalidade não é nada mais do que uma oposição à temporalidade. Todavia, denominação torna-se extremamente incabível quando pensamos na temporalidade existencial, que não é supra-histórica, mas determina-se pelo cuidado, pela finitude humana. A temporalidade é o próprio modo de ser da compreensão humana e a experiência da arte é humano-finita, ou seja, insere-se no tempo. A arte, portanto, não deve ser inserida em um tempo sagrado, subtraindo-se ao tempo, sendo que a verdadeira questão é de como se insere no tempo e na história.

As tentativas de furtar-se à temporalidade da literatura serão vãs, na medida em que, por mais que o escritor pretenda recorrer a uma liberdade abstrata, exigindo que os leitores rompam com seus vínculos históricos e o encontrem na universalidade do tempo, estará negando uma suposta razão abstrata à história e unindo-se, justamente, a um determinado modo de relacionar-se com a verdade do ser, determinante daquele dado momento histórico.

$\mathrm{O}$ verdadeiro modo de ser temporal da arte constitui-se de uma viagem no tempo, de um partir de determinada época e contexto social e de diversos portos de chegada, que acontecem nos momentos de sua representação e leitura, que têm o caráter, a princípio, de repetição do mesmo. Todavia, como vimos, isso não significa que algo seja reconduzido ao original. Muito pelo contrário, além de o original ter se conduzido em um longo caminho, a própria repetição é um reiluminar tão original quanto a própria obra, é um presente sui generis. Dessa forma, a literatura pode ser considerada um ente temporal em um sentido radical, uma vez que só possui seu ser no devir e no retornar.

A literatura, enquanto linguagem ${ }^{127}$ carrega, mais especificamente, todas as mudanças da humanidade, toda a relação dos homens com o ser ao longo do tempo, caracterizando a verdadeira história. A partir da linguagem conseguimos, enquanto seres finitos, estarmos sempre vindo de muito longe e também indo, transformando a efemeridade da nossa situação de mundo, encontrado lugar não somente a persistência,

\footnotetext{
${ }^{127}$ Também a tradição que chega a nós, assim como a experiência do mundo, é reconduzida à linguagem, na medida em que a compreendemos e interpretamos.
} 
mas também o devir e a transformação. Podemos perceber pela linguagem e pela literatura, enquanto linguagem e arte, por exemplo, a mudança dos costumes e valores, a mudança da relação do homem com o ser, a aletheia.

A simultaneidade da literatura não é, portanto, a atemporalidade correspondente à eternidade, mas sim o caminho percorrido e a atualidade alcançada com a linguagem na representação, na leitura, o estar no tempo presente, mesmo que sua origem seja muito remota (GADAMER, 2007a, pp. 178-186).

De fato, a obra de arte do passado e, mais especificamente, a literatura são frutos arrancados de uma árvore, despojados de seu contexto original, do clima, da árvore, da terra, nenhum dos elementos que dominavam o processo de seu devir original. Todavia, em sua queda, o fruto despojado encontrou outras formas de movimentar-se, e é importante ressaltar que não se deve tentar reconstruir esse mundo original; primeiramente porque seria em vão, não é nada mais do que uma lembrança e a investigação acerca daquela ocasião não está em condição de reconstruir a obra de arte em seu ser. A relação com o contexto histórico original permanece, portanto, imaginativa. A atualidade da obra, não é a atualidade de seu contexto original, mas a do horizonte ${ }^{128}$ em movimento, que constitui também a tradição em movimento. A tarefa hermenêutica que tanto discutimos passa por uma dialética originária, do diálogo originário, e não pela reconstituição do passado, que se foca em um processo estático e rígido, de um horizonte como fronteira rígida.

${ }^{128}$ O horizonte, representando o fluxo do anterior e do posterior em movimento, no contínuo da vida, não é uma fronteira rígida, mas algo que se desloca com o leitor, ou com a obra literária, que possui uma valência ontológica própria $(*)$, e convida a que se continue a caminhar.

(*) Tudo que está dado como ente que possui um devir e leva consigo o horizonte do mundo. 


\section{LITERATURA E ESCRITA COMO CONSTRUÇÃO E REIFICAÇÃO}

A literatura é uma das mais distintas formas de reificação ${ }^{129}$, segundo Arendt, porque pede um grau mínimo de reificação e, portanto, de amortecimento, uma vez que seu nível de materialismo é pequeno. Nesse sentido, também, a técnica do artista que compõe um poema ou uma peça de literatura não precisa ser muito aprimorada para que ele alcance excelência em sua obra. Basta que ele esteja familiarizado com a linguagem com a qual pretende trabalhar, o que é imprescindível para a comunicação em geral dos seres humanos e a configuração uma formação humanizadora (ARENDT, 2001, pp. 182-183).

Para Antonio Candido, a literatura, é, antes de mais nada, um objeto construído de grande poder humanizador, enquanto construção, enquanto organização de uma visão de mundo em palavras coerentes: "se fosse possível abstrair o sentido e pensar nas palavras como tijolos de uma construção, eu diria que esses tijolos representam um modo de organizar a matéria, e que enquanto organização eles exercem papel ordenador sobre nossa mente" (CANDIDO, 2004, p. 177).

No momento em que o autor organiza suas idéias, impulsos e emoções no papel, destaca-se do imediato, coloca-se acima do tempo presente, sendo que sua representação generosa passa a servir para os leitores representarem mentalmente suas próprias emoções e situações. A forma construída, portanto, promove uma elevação à universalidade, à generalidade, que assegura a permanência (CANDIDO, 2004, pp. 175-189). Nesse sentido, a literatura enquanto um objeto fruto do trabalho e construção do escritor é também formação: enquanto adquire uma habilidade e a exerce, o escritor adquire um sentido próprio que ultrapassa a si próprio, o imediatismo de sua existência, rumo à universalidade. Além do mais, a obra produzida adquire uma consistência autônoma, sendo também formada por quem a cria, e na criação a consciência reencontra a si própria (GADAMER, 2007a, pp. 47-55). Com a criação literária, um gesto efêmero e, por vezes, banal adquire transcendência, ganha sentido próprio.

\footnotetext{
${ }^{129}$ Vale ressaltar que a literatura como reificação no sentido aqui proposto, como fruto do trabalho humano, não é mero produto do mundo industrial, muito embora modernamente a produção editorial tenha conferido a ela este papel; mesmo porque a produção neste sentido está bastante vinculada ao tempo presente, estando sujeita a ser substituída por outra mais engenhosa ou mais moderna e está submetida ao princípio do desempenho.
} 
A escrita, enquanto trabalho escrito, e a literatura, enquanto participa da escrita, possui um caráter espiritual muito puro e depende amplamente do espírito que a compreenda. No deciframento e compreensão opera-se um milagre: a transformação de um objeto reificado no ser, vivo e coetâneo, da literatura.

Todavia, a literatura, enquanto materializa-se nas letras impressas no papel, no ente por si subsistente livro, ou em outras formas que a tecnologia pode vir a propiciar, deixa de ser uma relíquia, vive somente a partir do ato da leitura: da participação no leitor e intérprete em sua existência, na apropriação de seu significado na história e nas vidas humanas como formação, caso contrário, é letra morta:

Deus sabe o quanto os cemitérios são tranqüilos: não existem mais ridentes que uma biblioteca. Os mortos lá estão: nada mais fizeram senão escrever, há muito tempo estão lavados do pecado de viver, e, de resto, só conhecemos as suas vidas através de outros livros que outros mortos escreveram a seu respeito. (...) $\mathrm{O}$ crítico vive mal; sua mulher não o aprecia como seria de se desejar, seus filhos são ingratos, os fins de mês são difíceis. Mas ele ainda pode entrar em sua biblioteca, apanhar um livro na estante e abri-lo. Do livro escapa um leve odor de porão, e tem início então uma estranha operação que ele decidiu chamar de leitura. Por um lado, é uma possessão; empresta-se o corpo aos mortos para que possam reviver. Por outro, é um contato com o além. De fato, o livro não é um objeto, tampouco um ato, nem sequer um pensamento ${ }^{130}$ (SARTRE, 2006, p. 24).

A invenção da escrita operou uma verdadeira transformação, não uma mera adição à oralidade, mas mudou completamente a forma dos seres humanos viverem a tradição e a permanência. O indivíduo que compreende é liberado da transmissão oral ganha uma possibilidade de ampliação dos horizontes, apropriando-se da tradição literária. O texto manuscrito ou impresso não é uma relíquia, mas representa a continuidade de uma memória, do horizonte da tradição em movimento.

\footnotetext{
${ }^{130}$ Na realidade, Sartre não enxerga essa ressurreição da literatura após um longo tempo de sua escrita com bons olhos. Ele possui uma concepção da literatura bastante ocasional, sendo que os livros escritos por pessoas mortas, não têm mais lugar nesta terra, fala de coisas mortas. Como se os sentimentos expressos em um livro falassem não mais de sentimentos que podemos sentir, mas unicamente de afeições exemplares, ou seja, de valores. Todavia, ele não concebe a existência da literatura como autônoma, sequer a temporalidade de seu modo de ser, valorando-a somente por sua ocasionalidade, no contexto em que foi criada, como denúncia e discurso político fugaz. Veremos, contudo, que, em diversos momentos da obra Que é a literatura?, ele se contradiz nesse ponto, passando a reconhecer que as obras que têm sucesso em transmitir as pequenas obstinações pessoais de um homem que foi de carne e osso, ou quando expõe as virtudes, os vícios, e a grande dor que os homens têm de viver, sua "mensagem" extrapola a ocasionalidade. No fundo, percebemos que sua intenção não é criticar a temporalidade da literatura, mas criticar o modo de interpretação da consciência histórica do qual se valem alguns críticos literários, cujo objetivo, "não é tornar Pascal e Montaigne mais vivos, mas sim Malraux e Gide mais mortos" (SARTRE, 2006, p. 29).
} 
Nenhum outro objeto ou manifestação artística que traz à fala a tradição se parece com a escrita, visto que sofrem mais intensamente a erosão do tempo, e seu significado não vem à tona com a leitura, como um feitiço que liberta e cria o entendimento. As teorias que se propõem a decifrar uma dada relíquia não se criam a partir da própria relíquia, mas operam como a recordação ${ }^{131}$ e, necessariamente, a partir dos fatos passados, ao passo que a escrita realiza por si só a pura atualidade do passado (GADAMER, 2007a, p. 230): "é só a tradição escrita que pode desligar-se da mera persistência de resíduos de uma vida passada, a partir dos quais é possível à existência (dasein) remontar a outra existência completando-a" (GADAMER, 2007a, p. 506).

Nem sempre a escrita e a literatura formaram um conjunto, sendo a escrita a expressão material do modo de ser literário. Muito antes disso, as inscrições foram utilizadas para registros de transações econômicas; contudo, é evidente que o que chamamos de literatura procurou e vem encontrando formas de permanência cada vez mais eficientes, extrapolando os meros monumentos e signos. A literatura escrita, portanto, se eleva aos olhos de todos, para uma esfera de sentido na qual pode participar qualquer leitor.

Em última análise, para Arendt, os homens atuam para que o produto de suas atividades e seu discurso possam sobreviver, imortalizando-os ${ }^{132}$ e imortalizando os personagens e situações de seu tempo. Algo de individual alcança plena atualidade na sua representação, por mais remota que seja a sua origem. Até mesmo o mais modesto escritor possui essa pretensão ao escrever, qual seja, de construir sua obra para que essa venha a alcançar a máxima ressonância. Nas palavras de Sartre (2006, p. 21): “quando fala, ele [o escritor] atira. Pode calar-se, mas uma vez que decidiu atirar é preciso que o faça como um homem, visando o alvo, e não como uma criança, ao acaso, fechando os olhos, só pelo prazer de ouvir os tiros."

O escritor deve engajar-se inteiramente na empreitada da escrita como em uma escolha, com o total empenho de viver. Muitas vezes, a sobrevivência da literatura serve ao escritor que não atende as expectativas de seu tempo ou se vê preterido pelas instituições contemporâneas, mas que não perdeu o desejo de exercer uma ação direta no mundo, no contexto de uma coletividade. Não sendo essa ação possível no presente, projeta para um futuro indeterminado a conciliação com o público e até o prestígio

\footnotetext{
${ }^{131}$ Como sinal, que cria uma referência, remete a um acontecimento passado.

${ }^{132}$ Contudo, considerando mesmo a função ideológica conferida às obras por seus autores e por seu contexto, poucos espíritos são conscientes da função histórica de suas obras em sentido amplo.
} 
póstumo (SARTRE, 2006, p. 97). O autor postula a eterna repetição de sua obra, em um futuro indefinido e infinito, que compensaria o malogro no presente.

A literatura, como considerada por Antonio Candido, não se trata somente de manifestações literárias isoladas, mas também de um sistema de obras ligadas por denominadores comuns, compostos de características internas (língua, temas, imagens), além de sociais e psíquicas, que se manifestam historicamente e fazem da literatura aspecto orgânico da civilização. Quando, portanto, a atividade dos escritores integra-se em tal sistema, ocorre a formação da continuidade literária, que assegura no tempo um movimento conjunto e a linearidade do todo da tradição literária ou de determinado movimento literário. Seria, portanto, nas palavras de Candido (2006a, pp. 25-26):

uma tradição, no sentido completo do termo, isto é, transmissão de algo entre os homens, e o conjunto de elementos transmitidos, formando padrões que se impõem ao pensamento ou ao comportamento, e aos quais somos obrigados a nos referir, para aceitar ou rejeitar. Sem esta tradição não há literatura, como fenômeno de civilização.

Assim, a partir do discurso, da palavra, que alcança perenidade e presença na literatura, ela passa a integrar a tradição comum da humanidade e/ou específica de um determinado povo ou indivíduo. A obra literária que consegue adquirir autonomia e extrapolar os limites do contexto de sua criação, como os clássicos, por exemplo, passa a integrar um todo. Essa obra passa a pertencer ao mundo e, a partir disso, ganha o status de literatura universal. O clássico, portanto, conserva-se porque diz algo a cada presente como se fosse dirigido a ele; não é o mero testemunho ou resquício de algo desaparecido. Algo em sua representação permanece vivo. 


\section{O CLÁSSICO}

Toda a preservação e transmissão dos chamados clássicos constituem uma tradição cultural viva, que não se limita a conservar o que existe, mas também procura seu reconhecimento e transmissão como modelo, quer de valores, quer de forma e criação literária. Todavia, hoje não se pode mais interpretar o conceito de clássico ${ }^{133}$, surgido na Antiguidade $^{134}$ e atuante na canonização de determinados escritores, como se o mesmo pudesse exprimir um ideal, quer de valores, quer de estilo ${ }^{135}$. O conceito de clássico designa, antes, uma fase temporal e não mais um valor supra-histórico. Por outro lado, será que o que chamamos de "os clássicos" não pode ainda ser identificado com obras que passaram a compor a literatura universal ${ }^{136}$ ?

De qualquer forma, o sentido normativo do clássico jamais foi abandonado por completo, quer no uso terminológico antigo quanto no moderno ${ }^{137}$; porém, na medida em que é referida retrospectivamente a uma magnitude única do passado que a apresentou, essa norma contém um tom temporal, um tom de autoridade da tradição, que a articula como parte da história. Ainda, no que diz respeito à literatura grega clássica, esta se eleva

\footnotetext{
${ }^{133}$ Definições extraídas do Dicionário Houaiss da Língua Portuguesa (2001): "2 relativo à literatura, às artes ou à cultura da Antiguidade greco-latina; 3 que é fiel à tradição da Antiguidade greco-latina ou a seus autores; 4 que serve como modelo; exemplar; 5 abonado ou autorizado por autores tidos como paradigmas; 6 que segue ou está de acordo com os cânones ou usos estabelecidos ou que é conforme com um ideal; tradicional."

${ }^{134}$ Como se na Antiguidade, uma determinada fase evolutiva do devir histórico da humanidade houvesse produzido uma conformação do humano madura e completa, insuperável, que servisse de modelo. Evidentemente que os gregos sempre almejaram alcançar com suas obras mais do que o ser humano individual, mas "acima do homem como ser gregário ou como suposto eu autônomo, (...) o Homem como idéia" (JAEGER, 1986, pp. 10-11); no entanto, não consideramos aqui a idéia de um modelo que homem, de um modo de ser humano adequado à sua humanidade, um esquema vazio, independente do espaço e do tempo. O ideal de homem a ser transmitido, seria, antes, uma forma viva que se desenvolve e persiste através das mudanças históricas, incorporando e aceitando todas as transformações de seu destino. O humanismo e o classicismo de outros tempos ignoraram este fato ao falarem da "humanidade", da "cultura", do "espírito" dos gregos ou dos antigos como expressão de uma humanidade atemporal e absoluta.

${ }^{135}$ Com relação ao estilo, o que passou a denominar-se "clássico" sequer era unívoco: o conceito foi sofrendo transformações e distanciando-se da sua concepção antiga (GADAMER, 2007a, pp. 379-388).

${ }^{136}$ Vale mencionar que a nomenclatura "literatura universal" pode causar estranhamento, tendo em vista que a universalidade pode vir a ser interpretada como um conceito que leva a permanência e presença da literatura a caminhar para um espaço e tempo abstratos e eternos: à atemporalidade e ao não espaço, sem vinculação à liberdade concreta e às situações existenciais dos indivíduos e dos povos, bem como ao tempo e espaço percorridos pela literatura, que vêm agregar a ela sentido. Por esse motivo, a expressão clássico será aqui preferida. Quando utilizada a expressão universal, contudo, será no sentido da dimensão humana, com uma tendência a percorrer o todo da humanidade, contemplando as especificidades de suas partes a partir da hermenêutica literária.

${ }^{137}$ No pensamento moderno, o conceito de clássico acabou sendo empregado para toda a Antiguidade Clássica, no momento em que o classicismo e o humanismo proclamam novamente e equivocadamente o caráter modelar dessa Antiguidade, sem qualquer atenção a sua historicidade. O povo grego transmitiu à posteridade, de forma imorredoura, um tesouro de conhecimentos, porém, seria um erro fatal ver nesse legado uma norma rígida e definitiva.
} 
acima da esfera do puramente estético, onde a pretenderam em vão encerrar, exercendo um influxo incomensurável através dos séculos.

A consciência histórica propõe-se, antes de tudo, ao conhecimento do que realmente foi e como foi. No seu apaixonado intento de ver claramente o passado, considerou os clássicos como um mero fragmento da história - embora um fragmento da maior importância, a ser considerado como modelo ${ }^{138}$-, sem, contudo, atentar para sua contingência, expressa por meio de sua influência no mundo através dos tempos, independentemente de sua normatividade estética e formal.

A respeito dessa influência, dir-se-á que "os clássicos são livros que exercem uma influência particular quando se impõem como inesquecíveis e também quando se ocultam nas dobras da memória, mimetizando-se como inconsciente coletivo ou individual" (CALVINO, 2007, pp. 10-11). Os clássicos passam a integrar um sistema articulado, influindo também sobre a elaboração de outras obras e formando, no tempo, uma tradição (CANDIDO, 2006a, p. 26).

Com o tempo foi sendo criada uma grande desconfiança dos cânones, devida, principalmente, ao seu caráter normativo. No entanto, é importante que se lembre que a vida literária dentro da história cultural de um povo não erige padrões eternos e imutáveis, porém, não é possível uma tradição existir sem tais padrões (FREDERICO; OSAKABE, 2010). Assim: vivemos a época da informação coletiva e rápida, e a leitura literária é solitária e lenta; o relativismo cultural dominante coloca em cheque as antigas tabelas de valores, sem, no entanto, as substituir por outras; passam a ser buscadas respostas simples às grandes questões filosóficas e existenciais em manuais de auto-ajuda (PERRONEMOISÉS, L., 2006b, p. 27).

Existe, contudo, uma abordagem não normativa na leitura e no ensino dos clássicos, que atenta à sua temporalidade:

Assim, a noção de cânone guarda relação com a transitoriedade, com a época e sua fugacidade, mas, também, com a permanência. Por isso, embora nada se possa considerar definitivo em matéria de excelência

\footnotetext{
${ }^{138} \mathrm{O}$ enfoque estrutural dado à literatura, portanto, não se concentra tanto na obra em si mesma, mas principalmente em relacioná-la a um modelo virtual abstrato. Antonio Candido explica que referidos modelos não seriam a-históricos, mas talvez trans-históricos, porque possuem generalidade e permanência muito maiores em relação às manifestações particulares, permanecendo como princípios de organização. Dessa forma, escapam até certo ponto à história, na medida em que são modelos, ao mesmo tempo em que se integram a ela, quando vistos em suas manifestações particulares. O ponto de vista estrutural esforça-se, portanto, por eliminar em sua análise os elementos que acentuam o caráter de produto contingente, mergulhado na história, da obra (CANDIDO, 2002, pp. 78-79).
} 
estética, dificilmente se poderá considerar como gratuito o efeito de permanência de obras que mantêm, mesmo com o passar dos séculos, o vigor do momento de seu aparecimento (FREDERICO; OSAKABE, 2010).

De certa forma, os clássicos carregam consigo a capacidade de causar certo estranhamento no leitor, convidando-o a deslocar-se de sua percepção cotidiana e, em geral, impessoal do mundo, tendo em vista que nos convidam a dialogar com um momento histórico alheio, mas que integra nossa própria tradição. Evidentemente que a leitura de um clássico, porque linguisticamente mais afastada, exige de nós mais do que a leitura de uma obra de fácil acesso e interpretação, todavia também é mais surpreendente.

Deste modo, se abordarmos os clássicos em vista da temporalidade da literatura, chegaremos a uma definição bem mais interessante do que os conceitos de clássico propostos. Nela, o clássico permanece uma categoria histórica, mas não porque designa o conceito de uma época, ou o conceito histórico de um estilo, mas porque é mais do que isso, mais do que uma qualidade a ser atribuída a determinadas obras e períodos. Seria, antes, o modo de ser do próprio ser histórico literário, caracterizado pela conservação e confirmação renovada a cada presente: "no fundo, o clássico é algo muito diverso do que um acordo descritivo em poder de uma consciência histórica objetivadora" (GADAMER, 2007a, p. 381).

Assim, os clássicos sempre trazem consigo as marcas de suas leituras e interpretações ao longo do tempo e os traços que deixaram nas culturas pelas quais passaram e ajudaram a compor, marcados na linguagem e nos costumes. Desse modo, o clássico é caminhar na temporalidade do horizonte histórico em movimento e em constante renovação. Inclusive, é bastante difícil de distinguir na leitura, e talvez nem se deva pretender, qual o significado originário da obra e as incrustações, "deformações" e dilatações às quais foi submetida ao longo de sua jornada.

Chamar uma dada obra literária de clássico, por conseguinte, é reconhecer seu significado imorredouro, sua conservação e permanência, sua função total ${ }^{139}$. A obra literária que está entre os clássicos é aquela que não é um mero testemunho de outra época, mas conserva um sentido atual em todas as épocas e realiza, por seu próprio sentido, a constante mediação com o passado. No entanto, o que chamaríamos de atemporalidade do clássico, que é a universalidade no tempo, seria, na verdade, o seu modo de ser histórico, temporal.

\footnotetext{
139 Aquilo que distingue o clássico talvez seja só um efeito de ressonância que vale tanto para uma obra antiga quanto para uma moderna, mas já com um lugar próprio na tradição (CALVINO, 2007, pp. 9-16), a sua função total.
} 
O clássico ocupa um lugar na consciência de todos, participa do todo da tradição, pertence ao mundo, mesmo que o mundo ao qual pertença esteja muito distante e afastado do mundo original ao qual a obra falou. O que é claro, contudo, é que essas obras continuam falando, mesmo que seu contexto original seja remoto ${ }^{140}$. Todavia, não se pode estabelecer uma distinção entre o modo de ser de uma obra segundo sua determinação original e o modo de ser posterior, pelo menos no que diz respeito ao tempo, pois a literatura possui um modo de ser histórico a qualquer tempo, sendo isso, justamente, o que permite que uma obra passe a integrar a literatura universal e galgar a posição de clássico (GADAMER, 2007a, pp. 227-228).

Mesmo quando se procura avaliar uma determinada obra a partir de uma consciência histórica ${ }^{141}$, sempre haverá algo a mais do que a mera reconstrução do mundo passado e do significado da obra àquela época, porque é necessário, no mínimo, que se reconheça a vinculação daquela obra com o nosso próprio mundo, como uma co-pertença. A filiação ao passado à qual remete a palavra clássico não exclui a força de expressão imediata que a obra conservou, e que garante sua validez e pertença à tradição e ao presente.

Por sua constante renovação, tem-se que o clássico se renova também a cada leitura que fazemos dele. Cada leitura carrega uma surpresa, imprime um novo significado à obra e a nós mesmos. As letras no papel da obra podem ter se mantido as mesmas, mas com certeza nós nos alteramos, e o novo encontro é um acontecimento completamente novo.

Assim, o modo de ser temporal e a presença que se faz por meio de seu próprio sentido fazem da literatura jamais passada. Com isso, além de pertencer sempre ao mundo, à história, e não pairar acima deles, como pretende a distinção estética, a literatura é sempre presente, por mais que esteja despojada do seu sentido original.

\footnotetext{
${ }^{140}$ A tradução de algumas obras para diversas línguas também é uma comprovação de sua validez perene.

${ }^{141}$ Consciente do distanciamento histórico, que procura compreender a obra a partir da época de criação.
} 


\section{Literatura E TradiÇÃo}

O todo da tradição pode adquirir uma dimensão maior ou menor, se considerarmos os diferentes povos e suas culturas, todavia, sempre tende a fazer parte de um arcabouço comum a toda humanidade, de acordo com a própria tendência à amplidão da literatura. Algo que a literatura também traz consigo são os elementos de um sistema de valores que vai sendo agregado à tradição:

De fato, as leituras da juventude podem ser pouco profícuas pela impaciência, distração, inexperiência das instruções para o uso, inexperiência da vida. Podem ser (talvez ao mesmo tempo) formativas no sentido de que dão uma forma às experiências futuras, fornecendo modelos, recipientes, termos de comparação, esquemas de classificação, escalas de valores, paradigmas de beleza: todas, coisas que continuam a valer mesmo que nos recordemos pouco ou nada do livro lido na juventude. Relendo o livro na idade madura, acontece reencontrar aquelas constantes que já fazem parte de nossos mecanismos interiores e cuja origem havíamos esquecido. Existe uma força particular da obra que consegue fazer-se esquecer enquanto tal, mas que deixa sua semente (CALVINO, 2007, p. 10) (grifos nossos).

Todavia, esses valores são, em um momento de maior amadurecimento - em que o indivíduo passa a fazer suas próprias escolhas -, repensados livremente e podem ou não ser incorporados pelo leitor a partir de seu entendimento, tendo em vista que a história, do ponto de vista ontológico, não pode ser reduzida ou calculada em valores.

A tradição não nos consagra valores eternos, visto que estes são uma forma de desvencilhar-se da verdadeira história sem tê-la de fato, compreendido; sem ter compreendido o sentido da tradição e do diálogo (HEIDEGGER, 2008c, p. 163). Veremos que o diálogo permite que a autoridade da tradição seja repensada criativamente, possibilitando o reconhecimento dos próprios efeitos da história efeitual em toda nossa compreensão do mundo em que fomos lançados, bem como a compreensão da ética a partir da existência humana.

O que é consagrado pela tradição como herança histórica possui uma autoridade que se tornou anônima, possuindo uma validez que independe e prescinde de fundamentos evidentes, tendo poder sobre nossa compreensão, ação e comportamento. Inclusive, essa é a base de toda educação. Mesmo quando superamos o momento da vida em que a educação é tutelar, ou seja, quando passamos a assumir nossas próprias decisões, antes detidas em 
grande medida pela autoridade do educador, mesmo então não nos libertamos da herança histórica e da tradição. A literatura é uma das formas pelas quais a tradição nos interpela. $\mathrm{O}$ fundamental para a liberdade e autenticidade é que a educação e a tradição sejam pensadas de forma emancipadora e ética. No sentido em que a ética é a própria morada do ser e de nossa liberdade.

Sendo Homero um expoente representante da cultura grega da Antiguidade, já reconhecemos seu valor enquanto fonte de nosso conhecimento histórico da sociedade grega antiga. Além de fonte histórica, o pathos do sublime destino heróico do homem, que constitui o espírito da Ilíada e da Odisséia, traz consigo uma reflexão ética imorredoura, que era a própria matéria da educação helênica conduzida por meio do traço poético.

A reflexão ética é travada, de forma imediata, a partir do próprio ethos de uma moral aristocrática, cuja sociedade que produziu tal forma de vida desapareceu. Contudo, referida educação não se dava por meio de problemas pedagógicos nem passagens de efeito moral: muito além de uma atitude que revela um propósito pedagógico objetivo, repousa outro tipo de educação derivada da própria essência do canto épico, que se destina a possibilitar manter viva a glória dos homens e dos deuses na memória do mundo. Partindo do mito, que permanece, secreto, em toda poesia, a épica tem uma função formadora e reveladora porque trata do ser e do destino humano, discutindo a ética em sua essência, para além da instância normativa do mito (JAEGER, 1986, pp. 46-47).

Vale mencionar que Homero não é um mero naturalista ou moralista. Para ele, como para os gregos em geral, as últimas fronteiras da ética não são convenções do mero dever, mas leis do ser que se realizam no desenvolvimento íntimo e necessário das ações, que se sucedem passo a passo, numa inviolável conexão de causas e efeitos. Assim, não há a simples aceitação passiva das tradições, mas sempre a luta em face do destino dos homens (JAEGER, 1986, p. 54).

A Ilíada supera, por meio da figura de Aquiles, a descrição do espírito guerreiro, constituindo um monumento imortal para o conhecimento da vida e da dor humanas. Assim, esse sofrimento é que será conhecido e arrebatará os leitores para sempre, muito além dos valores de uma sociedade aristocrática que não mais existe concretamente. Os dilemas e os problemas da vida, a luta em face dos deuses e do destino, é isso o que faz a 
Ilíada transcender o tempo. Aquiles, ao despertar a consciência aos problemas da vida colabora para o impacto que produz o conteúdo ético ${ }^{142}$.

A literatura, além de trazer a discussão e o conteúdo ético inerentes à representação do ser do homem, deixa um espaço para a criação livre dos valores, com base também na experiência dos povos. Homero e Hesíodo teriam criado literariamente os deuses para os gregos, tendo em vista que trouxeram para a complexa pluralidade da tradição religiosa dos gregos a sistemática teológica de uma família e fixaram pela primeira vez, através de sua literatura, figuras que se distinguem por sua forma e função. Imensurável foi essa contribuição da literatura para a tradição grega. Sua literatura promove, também, a universalidade da consciência religiosa, superando os cultos locais, sem, contudo, engessar as representações, tendo em vista que a palavra poética beira o inefável e o indizível. Deixou um campo aberto, portanto, para o preenchimento pela imaginação e pela fixação pelas artes plásticas locais, estas sim, fixadoras (GADAMER, 2007a, p. 204).

Hoje, no entanto, já não vivemos em um mundo em que uma lenda comum, um mito, a história sagrada de uma tradição surgida da memória coletiva rodeie nosso horizonte existencial com imagens que reconhecemos indistintamente nas palavras (GADAMER, 1993, p. 147). A formação do todo da tradição é um processo infinito e em constante expansão: o horizonte da tradição é móvel e perfaz a continuidade da memória do mundo. Os textos literários, cada uma das obras, trazem à fala esse todo da tradição, tendo em vista que sua interpretação se dá sempre considerando esse todo do qual a obra faz parte. Na leitura da obra, a autoridade anônima da tradição orienta em maior ou menor medida o intérprete. Assim, não só o texto literário é parte de um todo como também seu entendimento é influenciado por ele.

Apesar de a tradição ser, à primeira vista, o contrário abstrato da autodeterminação livre, já que sua legitimidade não necessita de fundamentos racionais, parece-nos que entre tradição e razão não há uma oposição tão incondicional, tendo em vista que a tradição melhor estabelecida também precisa ser cultivada, assumida; dependendo a tradição não da inércia, mas de um ato de conservação, que, no entanto, não se evidencia desse modo, permanecendo oculto, mas existente.

\footnotetext{
${ }^{142}$ A respeito da hipótese de a Ilíada ter sido escrita por mais de um autor, quer a arquitetura do poema seja ligada à concepção original ou a um autor posterior, deve ser considerada em sua forma atual e em seu todo, o que é de fundamental importância para o seu intento e seu efeito, resultado emblemático da história e do discurso construído conjuntamente por uma miríade de leitores e intérpretes.
} 
Em uma perspectiva mais particularista e menos universalista, estamos inseridos na tradição e somos por ela interpelados, não como algo alheio a nós, mas como algo próprio, parte de nossas vivências como parte constitutiva de quem somos. Os livros que passaram a compor a tradição nem sempre ensinam algo que desconhecíamos, mas, em grande medida, surpreendem por nos mostrar algo que sempre soubemos, como o desvendamento de uma origem, de uma relação prévia com aquela obra enquanto formadora de nós mesmos (CALVINO, 2007, pp. 9-16).

No momento em que o leitor entra em contato com a obra, está sendo introduzida a ele sua história oculta, bem como a de todo aquele presente que o rodeia. Não existe nenhuma consciência possível e finita que consiga apreender o todo da tradição; assim, toda apropriação da tradição é historicamente distinta das outras, não falsa, mas antes aberta à recriação, ao olhar do intérprete.

Toda vivência implica os horizontes ${ }^{143}$ do anterior e do posterior, que vêm formar uma unidade no fluxo da vida. Dessa forma, quando nossa história oculta nos é apresentada, ampliamos nosso horizonte do passado, que se apresenta como tradição, do presente e do futuro, permitindo-nos ver outras possibilidades, outras formas de nos projetarmos existencialmente no mundo com mais autenticidade.

Contudo, a tradição que conta a história oculta de um indivíduo não é uma voz uníssona, uma vez que, quando olhamos o passado, embora nosso interesse oriente-se para ele, este só adquire vida na luz sob a qual ele nos é mostrado. E esse prisma não deve ser suprimido no olhar ao passado, pois é assim que a tradição deve falar, como uma pluralidade de vozes nas quais ressoa o passado e que vêm se unir no leitor. Mesmo porque, hoje, já não vivemos em um mundo em que uma lenda comum, um mito, a história sagrada de uma tradição surgida da memória coletiva rodeie nosso horizonte existencial com imagens que reconhecemos indistintamente nas palavras. Não restam dúvidas de que vivemos em um mundo de fragmentos e dispersão e em uma fragmentada realidade lingüística; contrariando cada vez mais o pré-conceito norteador da filosofia moderna de que o pensamento e a razão, como características comuns a todos os homens, acabam por unir a todos (GADAMER, 1993, pp. 147-148). A literatura e a linguagem são semanticamente plurais e somente encontram uma unidade na interpretação do leitor.

\footnotetext{
143 Todo presente finito, humano, tem seus limites. A situação existencial, conseqüência da derrelicção, justamente caracteriza-se por representar uma posição que limita a visão das possibilidades do futuro, do passado etc. A cada situação corresponde, portanto, um horizonte, ou seja, "o âmbito de visão que abarca e encerra tudo o que pode ser visto a partir de um determinado ponto” (GADAMER, 2007, p. 399).
} 
Assim, a literatura traz a oportunidade de conhecermos melhor o nosso passado e os valores que ele carrega, na medida em que foram preservados pelas obras e suas vozes. Podemos perceber também a extensão de nossa inserção na tradição e influência desse todo sobre a compreensão particular de uma obra que, evidentemente, é parte desse todo. A leitura, portanto, deve proporcionar uma compreensão que se dá como um jogo no qual o movimento da tradição e do leitor fazem um intercâmbio. Não um intercâmbio entre sujeitos, posto que o próprio leitor e a própria obra estão inseridos no todo, mas um jogo em que o movimento da parte (obra, intérprete) ao todo da tradição e do todo à parte alcance sua realização mais autêntica.

Contudo, como falam as vozes da tradição? Como ela interpela o indivíduo? Ao contrário do que possa parecer, ela não é um simples acontecer, mas sim linguagem que fala por si mesma, inclusive por meio de nós mesmos. Porém, não se pode confundir a tradição com a opinião de um tu verdadeiro, como expressão de sua vida, mas sim como um conteúdo de sentido; que pode vir por meio da fala de um pai, de um livro de literatura, de um filme antigo, de uma cerimônia, da própria língua de um povo etc. Não ser a tradição a expressão de um tu real não significa que a experiência do intercâmbio e jogo com a tradição não possa ser hermenêutica, uma experiência do tu (GADAMER, 2007a, pp. 467-468).

No momento da leitura, da reprodução da obra literária, como visto, a tradição se torna um interlocutor que nos fala por meio da literatura e de nós mesmos. Estabelece-se uma relação como em um diálogo, que perfaz toda compreensão. Todavia, para que esse diálogo seja uma verdadeira fonte de conhecimento e de liberdade não pode pretender dominar e antecipar o outro reflexivamente, por meio de uma aparência dialética ${ }^{144}$, mas sim se colocando dentro da relação vital com a tradição. Nesse sentido, não nos tornamos senhores do passado, mas passamos a reconhecer nossa própria historicidade, que não é limite ao conhecimento, mas sua própria condição. Dessa maneira, "aquele que sai reflexivamente da reciprocidade de uma tal relação modifica-a e destrói sua vinculatividade moral” (GADAMER, 2007a, p. 471). Assim como no diálogo com o outro, precisamos nos abrir à tradição, permitindo-nos também ser transformados por ela, experimentando-a de fato como um tu, permitindo que nos diga algo.

\footnotetext{
${ }^{144}$ Quando procuramos nos elevar acima do nosso próprio condicionamento, retirando-nos reflexivamente da relação com o outro, perde-se toda a espontaneidade com que se orienta para o outro, não se estabelecendo uma relação imediata, mas reflexiva.
} 
Aquele que está aberto para que se lhe diga algo está aberto de maneira fundamental. Mas é claro que a abertura para a tradição resulta em uma pertença mútua, o que significa que toda apropriação da tradição é única e distinta. Isso porque todo sentido da tradição alcança aquela concreção em que é compreendido na relação com um eu que interpreta, ou seja, que está aberto, mas não lhe é submisso. 


\section{OCASiOnalidade Versus PermanênCia: O IMEdiato E O MEdiato}

A interpretação de uma obra cujo momento de criação original é remoto não deve partir das vivências ou fontes do escritor, a obra não deve ser lida com o método histórico, método este usual na pesquisa da história das fontes ou na pesquisa biográfica. A leitura deve partir da hermenêutica e da compreensão conforme as concebemos nos capítulos anteriores, permitindo que nosso saber possa ser colocado em xeque pela literatura, ou nela encontre sua própria confirmação e origem (GADAMER, 2007a, pp. 469-472).

Isso é mais evidente ainda quando tratamos da função total da obra literária em contraposição à ideológica e à social, tendo em vista que o elemento de ocasionalidade dessas é muito mais forte; partindo da pretensão de sentido do próprio escritor com sua obra e da pretensão de sentido emprestada da sociedade em dado contexto. No entanto, como o sentido do texto apresenta-se a seu intérprete, leitor, seu verdadeiro sentido não depende do aspecto ocasional do autor e de seu público originário.

Por outro lado, algumas obras estão ligadas a um momento ocasional, independentemente da interpretação que se possa realizar, como um portrait, cuja ocasionalidade pertence ao conteúdo central do significado da obra, quer isso seja explícito ou não. Aqui, a ocasionalidade tornou-se um significado unívoco e permanente que, embora implícito, colabora com o sentido do conjunto. Nesses casos, a referência histórica que se possa acrescentar para a compreensão da literatura é redundante e secundária, tendo em vista que o sentido já está lá (GADAMER, 2007a, pp. 207-208).

Ademais, a obra literária está ligada àquilo que faz referência a tal ponto que enriquece aquela ocasião e desencadeia um novo processo ontológico que transcende o imediato e passa a emprestar aquelas emoções e pensamentos aos leitores de outros tempos e contextos. A valência ontológica inclui também o momento ocasional, mas ele potencializado, projetado ao futuro, representado: “a 'ocasião' de seu vir à representação faz com que sua significação experimente um aumento de determinação" (GADAMER, 2007a, p. 209).

A obra literária é a fala da tradição, mais do que do passado, da tradição que envolve o presente. Por meio da leitura, a literatura deixa de ser a sobrevivência morta de um ser alienado e introduz em cada presente sua história oculta, como se um portal para a tradição se tivesse aberto. Desse modo, o fato de a literatura possuir um mundo originário, 
em que, muito provavelmente, exercia uma função social, não significa que, uma vez deslocada desse mundo, não possa ter realidade a não ser em uma consciência estética ${ }^{145}$ 146. Assim, quando a obra literária adquire autonomia e transcende seu mundo e de seu tempo, despoja-se de seu sentido original e demanda um espírito interpretador ${ }^{147}$, para muito além de uma consciência estética.

Apesar de a tradição possuir uma presença e autoridade relevantes em nossa educação formal, ela deve atuar para além da educação, como formação: não absolutamente normativa e dogmática, mas a partir da experiência livre do estranhamento, da criação e da apropriação. Por meio da formação, o homem rompe com o imediato e supera o mundo, deixando o passado tocá-lo com profundidade e projetando o futuro de forma enraizada:

(...) a escola deve fazer com que você conheça bem ou mal um certo número de clássicos dentre os quais (ou em relação aos quais) você poderá depois reconhecer os "seus" clássicos. A escola é obrigada a darlhe instrumentos para efetuar uma opção: mas as escolhas que contam são aquelas que ocorrem fora e depois de cada escola. É só nas leituras desinteressadas que pode acontecer deparar-se com aquele que se torna o "seu" livro (CALVINO, 2007, pp. 12-13).

A leitura desinteressada é formadora também porque provoca certo alheamento do mundo cotidiano. Ocupar-se com o não imediato é por si só um alheamento, o ocupar-se com algo que a princípio é de natureza estranha. Aprende-se, com a formação, que o diferente tem sua validade. Por isso mesmo, a formação naturalmente conduz a interesses teóricos, visto que estes nos levam para além do que se sabe e vivencia de imediato, como algo da reminiscência, pertencente à memória e ao que se oculta no pensamento, em geral se mantém calado. Aos poucos o estranho vai sendo incorporado e assumido em nosso ser, causando uma transformação. Até que passamos a nos determinar pelo estranho que escolhemos como "nosso": "o 'seu' clássico é aquele que não pode ser-lhe indiferente e que serve para definir a você próprio em relação e talvez em contraste com ele" (CALVINO, 2007, p. 13).

\footnotetext{
${ }^{145}$ Segundo a consciência estética, a verdadeira obra de arte seria aquilo que, abstraído de todo tempo e espaço, representa o objeto de uma vivência estética na presença do vivenciar (GADAMER, 2007, p. 223).

${ }^{146}$ Isso é algo sobre que a arquitetura pode nos ensinar, tendo em vista que, como obra de arte, sua pertença a um mundo é uma marca indelével (GADAMER, 2007, p. 221).

${ }^{147}$ Tudo que não está imediatamente em seu mundo original, como toda a tradição, a arte e demais criações espirituais, está despojado do sentido original, dependendo de intermediação, interpretação.
} 
A apropriação do mundo e da linguagem de passados remotos o suficiente para produzir uma separação necessária que nos aparte de nós mesmos ao mesmo tempo contém os pontos de partida ao retorno a nós mesmo, ao reencontro de nossas próprias possibilidades. O princípio é sempre o da criação e participação em um universo comum com o outro, todavia, agora, essa participação ocorre no todo da tradição.

A memória também precisa ser formada, reconhecendo-a como um traço essencial do homem histórico e finito. A memória trata-se de uma relação entre reter e lembrar, isto é, algumas coisas queremos guardar na memória e outras banir, sendo que só pelo esquecimento pode o espírito renovar-se completamente e ver tudo com novos olhos. Por outro lado, o esquecimento, a ruptura com passado, traz conseqüências bastante drásticas para nossa liberdade, visto que passamos a não compreender a influência da tradição em nossas ações e no mundo em que fomos lançados (GADAMER, 2007a, pp. 47-53):

Como é feliz a sina das inocentes vestais! $\mathrm{O}$ mundo esquecendo, pelo mundo esquecido. Brilho eterno de uma mente sem lembranças!

Não, que eu voe, que eu voe, longe como de pólo a pólo; Ergam-se Alpes entre nós! E revolvam-se oceanos inteiros! Ah, não venha, não escreva, não pense uma vez sequer em mim, Nem compartilhe sequer um tormento do que eu sentia por ti. De tuas juras desisto, a tuas memórias resigno; Esqueça, renuncie a mim, odeie o que quer que fosse meu! (tradução livre da autora) $^{148}$

(POPE, 1717)

Nesse sentido, o diálogo com a tradição não se acontece com uma mera recordação ${ }^{149}$, mas sim a partir do acontecimento do encontro e do desvelamento de uma obra, uma imagem na qual podemos nos demorar, com a qual podemos dialogar, e que participa do próprio ser do representado, que se faz presente naquela imagem. Assim, a

\footnotetext{
${ }^{148}$ Do poema original Eloisa to Abelard: "How happy is the blameless vestal's lot!/ The world forgetting, by the world forgot./ Eternal sunshine of the spotless mind!/ (...)/ No, fly me, fly me, far as pole from pole;/ Rise Alps between us! and whole oceans roll!/ Ah, come not, write not, think not once of me,/ Nor share one pang of all I felt for thee./ Thy oaths I quit, thy memory resign;/ Forget, renounce me, hate whate'er was mine.” (POPE, 1717)

${ }^{149}$ A recordação só tem valor para quem mantém um laço com o próprio passado, ou seja, perdem seu valor quando o passado que recordam não tem mais importância. Funciona como um sinal, como referência, sem conter nada do ser do referenciado. Na imagem literária, ao contrário, a referência ao representado parte de seu próprio conteúdo, e quanto mais nos aprofundamos nele, mais nos aproximamos do representado.
} 
obra literária não se esgota na função de referência ao passado, mas seu próprio ser participa da tradição que ela representa ${ }^{150}$.

A abertura para a tradição, portanto, é um momento de compreensão, de liberdade e de autoconhecimento, que coloca o ser humano novamente em face da tarefa existencial com a qual deve confrontar-se para definir sua existência. Quando nos inserimos nos valores da tradição de forma a conservá-los, realizamos uma conduta tão livre quanto a ruptura e a inovação. Assim, a ruptura de Sartre não seria o único caminho possível para a liberdade e para as possibilidades. Entretanto, a relação de liberdade com a tradição não consiste em reconhecê-la como um objeto, alheio a nós mesmos, com uma fé ingênua no método da objetividade, mas sim reconhecer nossa pertença a ela e dela a nós, como parte do mundo, bem como sua realidade histórica. Portanto, a liberdade e a autodeterminação devem ser buscadas na tradição que fala por meio de nós e no entendimento que temos dela.

A compreensão da obra literária, da maneira como queremos aqui colocar, não parte da compreensão de textos legados por civilizações antigas, por meio da filologia, a partir de seu próprio horizonte histórico; mas sim de um diálogo com um tu, como um jogo no qual se dá a interação entre a compreensão que o intérprete adquire da tradição, do mundo e de si mesmo. A distância do tempo, portanto, não afasta o texto de seu intérprete, muito pelo contrário, deve ser reconhecida como uma possibilidade produtiva do compreender.

A literatura, conseqüentemente, é fundamental para a situação finita de todos os homens, tanto porque leva a memória de cada época, de cada artista ou de cada herói que a compõem a cada atualidade em que se faz presente; mas também porque sua própria viagem ao longo da história promove o diálogo constante com a tradição e com os valores, fundamental para a formação ética dos homens:

Como as pessoas, os valores, que são idéias, nascem, padecem sorte vária e morrem. Sua raiz é modesta e comum. As necessidades elementares da vida individual, projetando-se na vida coletiva, se sublimam em normas. Essas, desfeita a placenta que as nutre, se apresentam como valores autônomos, eternos, universais. Em torno deles se constroem as ideologias, proliferam-se outros valores, forma-se o tecido das ilusões caras à existência (CANDIDO, 2006c, p. 270).

Embora as normas e valores sejam pretensamente eternos e universais, as relações entre os homens mudam, a relação do homem com a verdade muda, à medida que se

${ }^{150}$ Algumas recordações, contudo, conseguem extrapolar a mera função de símbolo, de referência, e adquirem sentido próprio e autônomo de representação. Como a literatura que em certa medida parte das experiências e das recordações do próprio autor. 
transformam suas técnicas e sua atividade econômica, política e de trabalho, perdendo-se, com isso, o fundamento e funcionalidade de alguns valores. Permanecem, porém, carregados de conteúdo afetivo, chocando-se a todo tempo com a vida, que os vence e ultrapassa. Devem, portanto, ser vistos como quando trazidos pela literatura e valorizados porquanto caminho que vem conduzindo os homens e sua relação com o passado, inclusive a nós mesmos; ao mesmo tempo, devem ser abordados sempre com fundamental liberdade.

Aqui, a questão do abismo do tempo sequer se coloca, da mesma forma que não se coloca a questão do abismo subjetivo, estando o homem inserido na tradição. A herança dos homens não cai no esquecimento e se relaciona com cada momento e com cada intérprete de forma diferente, como parte do mundo e da questão existencial.

Para os direitos humanos existe, ainda, um proveito específico que se tira do modo de ser temporal da literatura: o de relembrar acontecimentos bárbaros que jamais devem ser esquecidos, mesmo porque interferem no projeto de futuro dos povos e dos indivíduos que compartilham este mundo. Como discutido, a literatura não só relembra como uma cópia, ou como um objeto de recordação, mas sim como uma representação que traz sempre um conteúdo ético e humano pelo próprio significado que carrega. Nesse sentido, é evidente que o movimento dos direitos humanos dá força e atualidade às obras de caráter humanitário e, reciprocamente, a literatura pode provocar em cada um de nós o sentimento de urgência para tais questões, com implicações éticas e na grande tarefa existencial a ser enfrentada por todos. Assim, a investigação das condições ontológicas da vida deve reverter em nosso modo de vivê-la.

$\mathrm{O}$ arcabouço de valores apanhado pelos direitos humanos a partir dos escombros da modernidade ajuda a conservar o sabor amargo da literatura que evidencia as violações à dignidade humana, conferindo a essa literatura uma força insuspeitada em nossa própria determinação e realização dos direitos humanos por meio dela. Quando observamos as literaturas passadas, podemos nos surpreender com o fato de que, nelas, a história e a tradição que serve de suporte aos direitos humanos é tão antiga quanto a própria literatura que trata do problema do destino humano. Os direitos humanos enquanto um novo elemento, um evento no curso dos acontecimentos, apenas confere às obras um novo prisma por meio do qual sua verdade pode vir à tona na compreensão.

Desse modo, o tempo para a literatura é contínuo e produtivo ao compreender, agregando significado e possibilidades de significação. 


\section{UMA CRÍTICA AO ESQUECIMENTO: O DIREITO À MEMÓRIA NO BRASIL}

Considerando a toda discussão empreendida acerca da temporalidade da literatura e da importância da compreensão da tradição para que possamos viver em liberdade, cremos que seja interessante nos valermos de um exemplo para ilustrar tal questão.

Para a consolidação do Estado democrático brasileiro, consagrado com a Constituição Federal de 1988, seria fundamental compreender a tradição ditatorial, marcada pela violência e pela barbárie, que foi gradualmente dissolvida para dar origem ao regime democrático atual. Somos impelidos, por nossa existência temporal, a conferir à tradição algum significado a partir do horizonte em que vivemos; ou seja, é preciso que dialoguemos com a tradição no intuito de chegar a uma compreensão que servirá de base para os projetos de futuro (MAMAN, 2003, p. 54), tanto individuais como de toda a comunidade. Nesse sentido, como criar um projeto futuro da sociedade brasileira ignorando seu passado?

O processo de redemocratização do Estado brasileiro impôs à comunidade em geral, e aos familiares dos mortos e desaparecidos no regime militar em particular, um fardo ainda mais pesado do que o do perdão: o ônus do esquecimento. Naquele momento, a realização de um acordo para que o processo de redemocratização fosse realizado de forma "pacífica" passava pelo entendimento político de que os crimes cometidos pelos agentes do regime ditatorial seriam de alguma forma encobertos pelo esquecimento. Coroou esse pacto a Lei da Anistia (Lei $n^{0}$ 6.683/1979), sob cuja negociação havia possivelmente a consciência de que a menção a "crimes conexos" representava um perdão aos torturadores, sendo que essa menção extremamente dúbia resguardaria também todos os militares responsáveis por uma série de graves crimes e irregularidades (CONDE, 2010). Além disso, logo após a concessão da anistia, percebendo os militares a ameaça de irem a juízo em virtude dos crimes cometidos, passaram a intervir nos meios de comunicação que efetuavam o acompanhamento das investigações sobre as desaparições e mortes (SANTANDER, 2008). O passado foi sendo, desse modo, encoberto e desconstituído nos moldes de 1984 de George Orwell, em que as notícias de jornal e outros documentos eram retificados ou destruídos pelo Ministério da Verdade na medida dos interesses do Partido. Não se percebeu, contudo, que, com o véu que se colocava sobre a memória, estava-se realizando um aviltamento ainda maior dos seres humanos, porquanto uma violência que cerceava a própria possibilidade de cuidado com a existência humana enquanto liberdade mais fundamental. 
A aparente gradual transição do regime autoritário para o democrático ocultou uma ruptura do pior tipo, uma ruptura que custou o silêncio de toda uma tradição e, portanto, do passado que fala por meio dos homens. Essa ruptura pode ser lida como aquele alvo das investigações filosóficas de Arendt (LAFER, 1995, pp. 49-51): como um hiato entre o passado e o futuro que obsta a compreensão. O que chamamos aqui de esquecimento representou o aparecimento de uma brecha entre passado e futuro, cisão que impede que se lide de maneira apropriada com o passado a partir da memória e do entendimento. Assim, somente com o conhecimento e compreensão da intromissão da violência criminosa em larga escala no Estado brasileiro é que se poderia construir um novo modelo de Estado: que negasse com bases sólidas essa violência e criasse formas dialógicas de ação política.

Desde pelo menos 1995, Comparato (1995) (NASCIMENTO; MAIEROVITCH, 2010) conserva a mesma visão acerca do tema, que tangencia em muitos pontos essa reflexão. Em 1995, ele escreveu que em resoluções da Assembléia da Geral da ONU e em julgados das Cortes de Justiça se impõe aos Estados em cujo território ocorreu o desaparecimento forçado de opositores políticos três deveres fundamentais: (i) de apurar a verdade dos fatos, constituindo uma comissão de investigação; (ii) de indenizar as vítimas ou suas famílias; e (iii) de sancionar penalmente os autores desses crimes. Agora, quinze anos depois da publicação de referido artigo, as negociações entre o Poder Público, a sociedade civil e os familiares das vítimas possibilitaram que o Estado assumisse a responsabilidade pelos crimes, reconhecesse oficialmente grande parte das mortes e indenizasse as vítimas e as famílias. Contudo, a assunção da responsabilidade pelo Estado, contribuiu para que o passado não fosse desvelado, e, portanto, permanecesse no esquecimento.

Do direito à memória e à verdade decorre que, sendo os fatos desencobertos, com eles seríamos confrontados e lhes seria conferido significado. Ainda que as possibilidades de ação somente alcançassem a condenação social, da compreensão surgiriam outras possibilidades de compensação, punição ou até de perdão individual (FRONTALINI, 1991): a partir daí, a relação com a tradição se constituiria como um momento de liberdade e não de cega subordinação.

À luz dessa reflexão deve-se pensar a decisão a ser proferida pela Corte Interamericana de Direitos Humanos (caso $\mathrm{n}^{\mathrm{o}}$ 11.552) relativamente aos mortos e desaparecidos no Araguaia e à Lei da Anistia de 1979. Essa decisão deve ser conduzida por uma hermenêutica que se esforce por escutar o passado e o presente compartilhados por nossa comunidade. É preciso que se esteja sensível também aos discursos que clamam pela 
verdade e à diferenciação entre a anistia e o perdão, escolha íntima e pessoal de cada um. O perdão não deve estar a serviço de um fim, seja ele nobre ou espiritual, como a redenção ou a reconciliação, isto é, toda vez que se pretende restabelecer uma normalidade social, nacional, política ou psicológica por meio do sofrimento ou do perdão, ele não é puro. $\mathrm{O}$ ato de perdoar deve continuar a ser excepcional e extraordinário, colocando o impossível à prova, como se interrompesse o curso normal da temporalidade humana. O perdão, assim, tanto para Derrida como para Arendt tem o poder de interromper o curso dos eventos (PERRONE-MOISÉS, C., 2006)

Sem dúvida que a abertura dos arquivos da ditadura, enquanto fontes documentais do período, irá colaborar para a reconstituição dos fatos ocorridos à época. Esses documentos serão alvo da apreciação e análise pelo método histórico. Contudo, a compreensão do período ditatorial não depende somente dos fatos a serem descobertos, mas também de sua interpretação. E com isso a literatura pode colaborar bastante, carregando consigo uma representação do contexto repleta de expectativa e sentido, aguardando, somente, o espírito aberto e criativo do leitor. Um famoso poema do período pode ilustrar a forma como a literatura pode produzir essa compreensão:

No Caminho, com Maikóvski Assim como a criança humildemente afaga a imagem do herói, assim me aproximo de ti, Maiakóvski. Não importa o que me possa acontecer por andar ombro a ombro com um poeta soviético.

Lendo teus versos, aprendi a ter coragem.

Tu sabes, conheces melhor do que eu a velha história.

Na primeira noite eles se aproximam e roubam uma flor do nosso jardim. E não dizemos nada. Na segunda noite, já não se escondem: pisam as flores, 
matam nosso cão, e não dizemos nada.

Até que um dia, o mais frágil deles entra sozinho em nossa casa, rouba-nos a luz, e, conhecendo nosso medo, arranca-nos a voz da garganta. E já não podemos dizer nada.

Nos dias que correm a ninguém é dado repousar a cabeça alheia ao terror.

Os humildes baixam a cerviz; e nós, que não temos pacto algum com os senhores do mundo, por temor nos calamos. No silêncio de me quarto a ousadia me afogueia as faces e eu fantasio um levante; mas manhã, diante do juiz, talvez meus lábios calem a verdade como um foco de germes capaz de me destruir.

Olho ao redor e o que vejo e acabo por repetir são mentiras.

Mal sabe a criança dizer mãe e a propaganda lhe destrói a consciência.

A mim, quase me arrastam pela gola do paletó à porta do templo e me pedem que aguarde até que a Democracia se digne aparecer no balcão. 
Mas eu sei,

porque não estou amedrontado a ponto de cegar, que ela tem uma espada a lhe espetar as costelas e o riso que nos mostra é uma tênue cortina lançada sobre os arsenais.

Vamos ao campo e não os vemos ao nosso lado, no plantio. Mas ao tempo da colheita lá estão e acabam por nos roubar até o último grão de trigo.

Dizem-nos que de nós emana o poder mas sempre o temos contra nós.

Dizem-nos que é preciso defender nossos lares mas se nos rebelamos contra a opressão é sobre nós que marcham os soldados.

E por temor eu me calo, por temor aceito a condição de falso democrata e rotulo meus gestos com a palavra liberdade, procurando, num sorriso, esconder minha dor diante de meus superiores. Mas dentro de mim, com a potência de um milhão de vozes, o coração grita - MENTIRA! (COSTA, 2003, pp. 47-49)

A autoria desse poema, publicado originalmente no livro O Tocador de Atabaque, que reúne os poemas do autor escritos entre 1962 e 1969, é de Eduardo Alves da Costa. Porém, por trinta anos o poema foi tido por muitos como sendo de autoria de Vladmir 
Maiakovski (1893-1930), poeta, dramaturgo e teórico russo, freqüentemente citado como um dos maiores poetas do século XX. O poema foi divulgado em jornais, nos anos 70, com o crédito para Maiakovski; além disso, o psicanalista Roberto Freire incluiu o poema em um de seus livros e deu crédito ao escritor russo, colocando Eduardo como tradutor.

O fato é que o poema virou símbolo da luta contra o regime militar e seu significado nos fala até hoje. Porém a compreensão do poema pode ser estendida para além da luta contra aquele regime específico, mas como a expressão de uma luta transformadora de todas as realidades opressoras, cerceadores da liberdade humana. $\mathrm{O}$ engano acerca de sua autoria acaba colaborando para ilustrar muito bem a transcendência conquistada pelo poema, tendo em vista que não importa sua autoria, sequer seu contexto original, mas o significado que dialoga com cada presente e que pode vir a significar os fatos ocorridos durante o regime militar. Não porque foi escrito naquele período, mas pela própria mensagem imorredoura que carrega. O poema evita ao máximo falar com todas as letras, provocando o intérprete a desvelar e libertar seu significado por meio do não dito, do silêncio, resultante, nesse contexto, da própria opressão e de uma tentativa de libertar-se dela por meio da literatura.

O poeta, ao fazer referência a Maiakovski, demonstra, inclusive, que está aberto à tradição literária transformadora que o precede, não só aberto, mas caminha lado a lado com ela, está-no-mundo-com-Maikovski, a dialogar com ele. E seu caminho é longo, mais importante ainda que o destino. É o caminho da liberdade e da igualdade, que só se faz caminhando.

Arendt tinha uma enorme preocupação com a memória do totalitarismo, pois essa memória e sua compreensão evitariam que um evento das proporções do holocausto ocorresse novamente. Há de se pensar, portanto, no contexto presente, que a indiferença para com o outro é tão grande que se chega a permitir que a barbárie nos visite cotidianamente. Nesse contexto, qual seria o lugar da memória e da compreensão que são compartilhadas por toda a sociedade? Seu lugar é o caminho da formação ética, onde o espaço público seja também compartido e protegido. Dessa forma, a natalidade e a esperança do novo, que provêm da criatividade do início da ação conjunta que anima a vita activa poderão consolidar-se como categorias centrais, projetando-se este rumo às suas possibilidades mais autênticas. 
CONCLUSÃO

O Papel da Literatura na Promoção e EfetivaÇão Dos Direitos Humanos 
Como vimos, o presente trabalho procurou acompanhar o desafio da filosofia do direito de compreender os direitos não exclusivamente com base em sua relação normativa, mas também em seu conteúdo valorativo. A partir do conteúdo axiológico é que poderíamos começar a pensar a promoção e efetivação dos direitos humanos.

A partir do questionamento de como o entendimento acerca dos direitos humanos positivados pode influir em sua promoção, propusemos, sem a pretensão de alcançar qualquer conclusão definitiva, mesmo porque não existe tal coisa no campo da filosofia, uma reflexão acerca da interpretação da liberdade e da igualdade a partir da filosofia da existência e da sua visão do ser humano existente (dasein). Tal reflexão se pretendia uma tentativa de ressignificação desses direitos, e dos demais direitos humanos erigidos com base na liberdade e na igualdade, a partir de uma hermenêutica que atentasse para a transformação da relação do homem com o mundo e com a verdade ao longo do tempo.

Extraímos dessa tentativa a liberdade como autenticidade, reflexo da existência e da busca essencial da identidade dos homens, tentativa de superação da medianidade e do impessoal; e a igualdade como um reflexo do estar-no-mundo-com-o-outro, devendo os seres humanos preocuparem-se com o outro para que possam ser capazes de definir seu próprio caminho de forma autêntica.

Sempre atentando para a interpretação dos direitos humanos sob o prisma do ser humano existente, nos questionamos quais as formas de promoção e efetivação dos direitos humanos atentam de fato para a preservação ou resgate da humanidade dos homens e não para a propagação de uma doutrina. Nesse sentido, nos lembramos de que a Declaração Universal dos Direitos Humanos não é dirigida primordialmente aos Estados, mas a todos os indivíduos e entidades da sociedade, rompendo com a clássica divisão entre Estado e sociedade civil estabelecida principalmente a partir da revolução francesa, conferindo a todos os homens um pouco da responsabilidade pela efetivação dos direitos humanos em suas próprias vidas.

De fato, a Declaração Universal dos Direitos Humanos aponta para a promoção dos direitos humanos por meio da educação dos indivíduos e da formação da personalidade, em vista do fortalecimento do respeito aos direitos humanos e às liberdades fundamentais. Todavia, para que a educação proposta humanize em sentido profundo e seja integrada à existência de cada homem, deveria se propor a ser mais do que a educação em sentido meramente formal, mas sim a autêntica formação. 
A formação, desde a Paidéia grega, pretendia a educação por meio da ética dos homens, não no sentido estrito do ensinamento de valores, mas colocando em questão sua identidade e seu modo de ser que viriam a definir os objetivos e caminhos traçados por todos. Isso porque não existe maior convicção do que aquela forjada com base na ética e na liberdade.

Evidentemente que o conceito de formação teve muito a ganhar com as teorias existencialistas, uma vez que a educação abandona seu caráter de conhecimento como uma relação de subjetivação-objetivação, com vistas à dominação da natureza, da verdade e do outro, ao passo que se torna um resgate da pré-ocupação com a existência, recobrando a relação essencial do homem com a palavra e com o ser. Assim, o homem volta a encontrar uma visão mais primordial do mundo, que fora substituída pela visão técnica-científica.

Nesse sentido, a discussão ética sobe ao primeiro plano, passando o homem a cuidar de sua identidade, de quem é enquanto lançado ao mundo que compartilha com o outro. Os direitos humanos colocam em pauta, em primeiro lugar, a questão ética, e nesse sentido é que o papel da literatura é fundamental.

Os capítulos II, III e IV buscaram oferecer uma visão sobre o modo de ser da literatura que pode influir na forma como os homens estão no mundo e na forma como estão com os outros, sendo elas indissociáveis.

Primeiramente, a literatura nos coloca em contato profundo com uma linguagem mais próxima da linguagem do mito poético, recuperando um pouco da relação essencial do homem com a palavra. Assim, nos proporciona um desvelamento do mundo diverso do proposto pelo método e pelo enunciado científico, que visa à dominação. Ela nos apresenta para uma verdade no sentido da aletheia (encobrimento/desencobrimento do ser) e não no sentido da veritas romana, que tem por base o imperium e a adequação; quer pela palavra discursiva, que amplia o horizonte de possibilidades, superando o mundo circundante por meio da representação, quer pela poesia, que trava um jogo entre o dito e o não dito, trabalhando, portanto, com uma verdade inefável.

A literatura nos devolve um olhar originário para o mundo, possibilitando que nos deparemos com a questão da identidade e de nossa relação com o outro de forma mais autêntica, escapando à impessoalidade e à medianidade, porque descobrimos um olhar para o mundo que não ambiciona dominá-lo, ou ao outro.

Em segundo lugar, a literatura atua como uma forma de discurso, de atuação no espaço político livre, e de ampliação deste. O escritor discursa e revela ali quem ele, autenticamente, é e o que traz de novo ao mundo na medida em que expressa seu ser. A 
literatura, ainda, percorre espaços e possibilita a propagação do discurso em um espaço público muito mais amplo do que os leitores prefigurados.

Por outro lado, não podemos nos esquecer de que a outra face do discurso é o diálogo. Como a literatura só se consuma com a leitura e compreensão da obra, ela possibilita um diálogo hermenêutico entre o leitor e a obra, com a fusão dos horizontes de ambos e o compartilhamento da visão de mundo que trazem consigo, podendo o leitor vir a transformar-se, caso mantenha-se aberto às palavras que o falam.

Nesse sentido, quando Sartre parte em defesa da obra literária engajada, no início estranhamos que ele confira um viés claramente interessado à literatura. Depois compreendemos que o engajamento não é nada mais do que a generosidade do escritor para com seu leitor, na medida em que confia em sua liberdade para interpretar sua obra, reconhecendo, assim, sua liberdade. O inverso também ocorre, na medida em que o leitor permite-se se ser transformado pela obra quando se trava o diálogo da compreensão.

Por fim, exploramos a possibilidade de a literatura ser uma forma importante de estabelecermos um diálogo com a tradição que fala através dela. Somente podemos pensar em liberdade quando não ignoramos a importância da influência que o passado, que nos chega na forma da tradição, exerce sobre nossa existência.

De certa forma, todo escritor é um apanhador no campo de centeio, conservando certa visão e sua existência no significado de suas palavras, ao mesmo tempo em que o leitor também o é, pois resgata a juventude desse significado, tornando-o vivo em cada presente. A partir do diálogo com a tradição proporcionado pela literatura, o direito à memória ganha um novo significado, extrapolando o olhar da consciência histórica, e apontando sempre para uma compreensão do passado que possibilite que se usufrua de uma liberdade enraizada.

Esclarecido o papel da literatura na promoção e efetivação dos direitos humanos, resta-nos ainda um ponto a ser abordado para a conclusão desta dissertação. Trata-se da ameaça crônica que vem sofrendo a tradição literária nos últimos tempos. Desde a modernidade tecnológica e científica, modernidade esta contra-humanista com a sua cultura inflacionária da mente, a sobrecarga de imagens e ruídos no cotidiano têm sido crescente. Semelhante ao contexto descrito pela obra 1984, de George Orwell, em que a "teletela", além do papel de observadora, desempenhava outro: o de bombardeadora de imagens publicitárias e de um burburinho constante, uma vez que "o volume do instrumento podia ser regulado, mas não havia como desligá-lo completamente.” (ORWELL, 2009, p. 12). Sem 
mencionar os "Dois Minutos de Ódio", que se assemelham a alguns programas que podemos encontrar com certa regularidade nos horários nobres da televisão.

De acordo com Matos (2006), pesquisas mostram que, hoje, setenta e cinco por cento dos jovens (75 \%) têm algum som ligado enquanto lêem, como o rádio, por exemplo. Isso quando não têm a televisão ligada, que captura a atenção visual que deveria ser dirigida à leitura naquele momento. Semi-leitores tornam-se também pseudo-formados no pensamento e na vida. Assim, as crianças e jovens estão hipnoticamente ligados a equipamento eletrônicos no momento crucial em que deveriam passar pela formação ética, de sua forma de conhecer e estar no mundo, das preferências intelectuais e da sensibilidade. Essa reflexão é integrada no raciocínio empenhado para que se perceba a ameaça à literatura e suas conseqüências.

A leitura atenta, concentrada foi decretada inútil por seu anacronismo em uma época voltada ao consumo material e intelectual, bem como ao espetáculo midiático. A leitura e, com ela, a escrita deixaram de ser referência em diversas instâncias, pois não podem circunscrever-se na contração do tempo do mercado, do consumo e das tecnologias. Não que textos literários não sejam produzidos em abundância e que o mercado editorial não se empenhe em absorver essa exótica relíquia da humanidade, uma vez que até agora não foi possível suprimi-la; todavia, falta autenticidade nas obras e estas são produzidas, novamente citando Orwell (2009, p. 20), como que em "máquinas romanceadoras". A literatura é absorvida pelo impessoal e pela opinião pública e perde toda a sua luz própria sobre o mundo, distanciando-se do ser e das formas de enunciação poética, em que o não dito é tão ou mais eloqüente do que o dito.

O ensino da literatura no Brasil reflete essa fantasmagórica realidade, conforme mostramos a partir do texto de Leyla Perrone-Moisés (2006b), no Capítulo II. Ela observa que entre 2001 e 2002 houve o "desaparecimento" da disciplina literatura no ensino médio de diversos estabelecimentos de ensino brasileiros, tendo em vista que, segundo os documentos do Ministério da Educação brasileiro, a área antes denominada "Língua e Literatura" passava a se chamar "Linguagens, Códigos e suas Tecnologias". Desse modo, o aprendizado da língua portuguesa não se dá mais por maio da literatura, uma vez que aquela foi reduzida a um mero código, equiparável aos códigos de trânsito. $\mathrm{O}$ domínio desses códigos não mais é considerado como sendo da ordem do conhecimento, mas da tecnologia. A literatura foi absorvida, no âmbito da educação formal, pela técnica como instrumento de objetivação e controle da sociedade e da natureza. 
Por outro lado, o incentivo ao aluno para a constituição de sua identidade é completamente equivocado, uma vez que nessa proposta de ensino, os cânones são relegados a um segundo plano por, teoricamente, não refletirem a visão de mundo dos próprios alunos, que devem apoiar-se exclusivamente no presente e na linguagem a que estão habituados. Não se percebe, contudo, que com isso o aluno somente poderá buscar sua identidade a partir das próprias possibilidades oferecidas pela linguagem cotidiana e impessoal em que o aluno encontra-se imerso. $\mathrm{O}$ horizonte proporcionado por esse encontro limitado com a literatura é também deveras restrito, incluindo somente a visão dos padrões sociais valorizados naquele determinado momento e naquela determinada classe.

A partir desse diagnóstico, este estudo, que se propôs a fazer uma defesa da importância da literatura no processo de formação e humanização dos indivíduos e de sua autenticidade e reconhecimento, adquire especial relevo, uma vez que traz um apelo ao incentivo da literatura em suas formas mais diversificadas: não abolindo os chamados clássicos, mas integrando-os à produção e horizonte atuais, sempre em busca de obras, artistas e leitores autênticos e preocupados com o mundo e com seus semelhantes.

Nesse sentido, conclui-se esta dissertação com uma crítica à recente minuta de Declaração sobre educação e treinamento em direitos humanos da Organização das Nações Unidas $^{151}$ (NAÇÕES UNIDAS, 2010).

Educação e treinamento em direitos humanos compreende, segundo a minuta, "todas as atividades educacionais, de treinamento, informação e aprendizado com o objetivo de promover a cultura universal dos direitos humanos" (tradução livre da autora). Nesta definição já podemos encontrar uma colocação potencialmente problemática: qual seria a cultura universal dos direitos humanos, se tratamos de direitos, justamente, humanos e, pelo próprio modo de ser do humano, inseridos no tempo e no espaço? Talvez a única coisa universal sobre o humano seja a sua relação com o ser a partir da palavra, sua existência. A partir disso, alcançamos inúmeras conclusões especialmente no primeiro capítulo do presente trabalho. Todavia, os direitos humanos positivados devem, para alcançarem sua universalidade serem submetidos a uma atividade hermenêutica e dialógica constante, sendo interpretados como parte da tradição, como estranhos e ao mesmo tempo próprios a todos os povos.

${ }^{151}$ Draft United Nations declaration on human rights education and training. 
Assim, é muito difícil se falar em uma cultura dos direitos humanos, válida universalmente, que possa ser ensinada em todas as instituições de ensino. Mais tarde na minuta da Declaração sobre educação e treinamento em direitos humanos da Organização das Nações Unidas (2010) (item 5), podemos verificar o que se considera, nesse contexto, a cultura universal dos direitos humanos, qual seja, a cultura "na qual todos estão cientes de seus direitos e deveres em respeito aos direitos dos outros" (nossa tradução). Observa-se que se trata de uma definição bastante superficial, que, como era de se esperar, não consegue alcançar o objetivo de definir referida cultura.

As formas de educação em direitos humanos, para atingirem o modo de ser de uma formação, que se incorpore à vida dos indivíduos e se coloque em sua constituição ética, devem, como visto anteriormente, extrapolar e muito as atividades de educação formal. Isso é de certa forma contemplado pela minuta, tendo esta incluído as atividades educacionais informais dentre as que pretende regular; porém, ao longo da minuta fica mais claro que as atividades de educação e treinamento objeto da declaração abrangem majoritariamente atividades diretamente e explicitamente orientadas para o ensino dos direitos humanos como uma disciplina.

Somente no item 31 da minuta da Declaração sobre educação e treinamento em direitos humanos da Organização das Nações Unidas as artes são mencionadas como uma forma de orientar a educação em direitos humanos para as "riquezas" dos diferentes países, além de serem consideradas meios de treinar e aumentar a sensibilidade no campo dos direitos humanos. Todavia, a literatura, ao contrário do teatro, da música, das artes plásticas e dos trabalhos áudio visuais não é sequer mencionada. Evidentemente que por trás de algumas dentre as artes mencionadas se oculta um texto literário. Porém, talvez a literatura tenha sido tristemente suprimida por não integrar-se tão bem ao modo de ser da mídia e da indústria cultural, instrumentos inautênticos, mas que possuem um grande apelo a quem não quer se deixar perturbar pela questão da existência.

Não obstante a obliteração sofrida pela literatura em muitos momentos, ainda há exemplos de atos e discursos em sua defesa, que ressaltam sua importância na vida dos homens. O discurso de Mário Vargas Llosa (2010) para o Prêmio Nobel é um desses exemplos:

Se eu mencionasse neste discurso todos os escritores aos quais devo um pouco ou muito as suas sombras nos deixariam na escuridão. São inumeráveis. Além de me revelarem os segredos do ofício de contar, eles me fizeram explorar os abismos do humano, admirar seus feitos e 
horrorizar-me com os seus desvarios. Foram os amigos mais serviçais, os estimuladores da minha vocação, em cujos livros descobri que, mesmo nas piores circunstâncias, há esperança, e que vale a pena viver, nem que seja só porque sem a vida não poderíamos ler nem fantasiar histórias.

(...) graças à literatura, às consciências que ela formou, aos desejos e anseios que inspirou, ao desencanto do real com que retornamos da viagem a uma bela fantasia, a civilização é agora menos cruel do que quando os contadores de contos começaram a humanizar a vida com suas fábulas. Seríamos piores do que somos sem os bons livros que lemos, mais conformistas, menos inquietos e insubmissos, e o espírito crítico, o motor do progresso, nem sequer existiria. A exemplo de escrever, ler é protestar contra as insuficiências da vida. Quem procura na ficção o que não tem, diz, sem necessidade de dizer, e nem de saber, que a vida tal como é não nos basta para apagar a nossa sede de absoluto, fundamento da condição humana, e que deveria ser melhor. Inventamos as ficções para podermos viver de, alguma maneira, as muitas vidas que queríamos ter, quando apenas dispomos de uma só. Sem as ficções seríamos menos conscientes da importância da liberdade para que a vida seja suportável e do inferno em que ela se converte quando dominada por um tirano, uma ideologia ou uma religião (sem grifos no original).

Dessa forma, concluímos o presente trabalho alertando para o fato de que a formação em direitos humanos não deve buscar adequar-se ao impessoal e a uma visão inautêntica do mundo, atuando como uma doutrina. Deve sim alcançar as raízes de cada indivíduo na liberdade e em sua relação essencial com o ser, com o outro e com a palavra, de modo que os direitos humanos se tornem próprios a cada um, de forma a fazer sentido em suas vidas e em sua existência, como parte de seu ethos. 
REFERÊNCIAS BIBLIOGRÁFICAS 
AGAMBEN, G., Homo sacer: o poder soberano e a vida nua. Belo Horizonte: Ed. UFMG, 2007.

ALVES, J. A. L. Os direitos humanos como tema global. São Paulo: Perspectiva, 1994.

ARENDT, H. A Condição humana. 10. ed. Rio de Janeiro: Forense Universitária, 2001.

ARENDT, H. Eichmann em Jerusalém: Um relato sobre a banalidade do mal. São Paulo: Companhia das Letras, 2007a .

ARENDT, H. As origens do totalitarismo. São Paulo: Companhia das Letras, 2007b.

ARISTÓTELES. Ética a Nicômaco. 4. ed., São Paulo: Martin Claret, 2008.

AZENHA JUNIOR, J. Goethe e a tradução: a construção da identidade na dinâmica da diferença. Literatura e Sociedade, São Paulo, n. 9, p. 45-59, 2006.

AZEVEDO, M. A. A. Lembrança de morrer. In: Obras completas. 8. ed. São Paulo: Cia. Ed. Nacional, 1942. p. 1. Disponível em:

$<$ http://www.portalsaofrancisco.com.br/alfa/alvares-de-azevedo/lembranca-demorrer.php>. Acesso em: 14 jan. 2010.

BAUMAN, Z. O mal-estar da pós-modernidade. Rio de Janeiro: Jorge Zahar, 1998.

BLATTNER, W. Heidegger's being and time. London: Continuum, 2006.

BLOOM, H. Como e por que ler. Rio de Janeiro: Objetiva, 2001.

BOBBIO, N. A Era dos direitos. Rio de Janeiro: Elsevier, 2004.

BOBBIO, N. Da estrutura à função: novos estudos de teoria do direito. Barueri: Manole, 2007.

BORGES, J. L. O Aleph. Globo: São Paulo, 2001.

CALVINO, I. Porque ler os clássicos. São Paulo: Companhia das Letras, 2007.

CANDIDO, A. O discurso e a cidade. São Paulo: Duas Cidades, 1993.

CANDIDO, A. A literatura e a formação do homem. In: Textos de intervenção.

São Paulo: Duas Cidades, 2002. p. 77-92.

CANDIDO, A. O direito à literatura. In: Vários escritos. São Paulo: Duas Cidades, 2004. p. 169-191.

CANDIDO, A. Formação da literatura brasileira. 10. ed., Rio de Janeiro: Ouro sobre Azul, 2006a .

CANDIDO, A. Literatura e Sociedade: estudo de teoria e história literária. 9. ed. Rio de Janeiro: Ouro sobre Azul, 2006b. 
CANDIDO, A. Paixão dos valores. Literatura e Sociedade, São Paulo, n. 9, p. 270-275, 2006c.

CASARES, A. B. A invenção de Morel. São Paulo: Cosac Naify, 2006.

CHUEIRI, V. K. Shakespeare e o direito. Revista da Faculdade de Direito da

Universidade Federal do Paraná, Curitiba, n. 41, p.59-83, 2004.

CÍCERO, A. Guardar. In: Guardar. Rio de Janeiro: Record, 1997. Disponível em: $<$ http://www.antoniomiranda.com.br/poesia_brasis/rio_de_janeiro/antonio_cicero.html $>$. Acesso em: 12 dez. 2010.

COMPARATO, F. K. Que fizeste de teu irmão? Folha de S.Paulo, São Paulo, 13 Ago. 1995. Caderno 1, p. 3.

COMPARATO, F. K. Ética: direito moral e religião no mundo moderno. São Paulo: Companhia das Letras, 2006

CONDE, M. Historiadores discutem revogação da Lei da Anistia. Globo, blogs, prosa online, [Rio de Janeiro], 1 jan. 2010. 1p. Disponível em:

$<$ http://oglobo.globo.com/blogs/prosa/posts/2010/01/09/historiadores-discutem-revogacaoda-lei-de-anistia-255996.asp>. Acesso em: 11 jan. 2010.

COSTA, E. A. No Caminho Com Maiakovski. São Paulo: Geração Editorial, 2003.

DERRIDA, J. The right to philosophy from a cosmopolitan point of view. In:

Negotiations: interventions and interviews. Stanford: Stanford University Press, 2002. pp. 329-342.

DICIONÁRIO HOUAISS DA LÍNGUA PORTUGUESA. Rio de Janeiro: Objetiva, 2001.

ÉSQUILO. Eumênides. [S. 1]: [S. n], 458 a.C.. Disponível em

$<$ http://www.scribd.com/doc/6581264/Esquilo-Eumenides> Acesso em: 11 dez. 2010.

ESTADO DE SÃO PAULO. Governo do Estado de São Paulo; Organização Poiesis Social de Cultura. Projeto PraLer: Prazeres da Leitura. Disponível em:

$<$ http://www.praler.org.br/>. Acesso em: 16 dez. 2010.

FREDERICO, E. Y.; OSAKABE, H. [S. 1]: [S. n], [S. d.]. Literatura. Disponível em $<$ http://www.moodle.ufba.br/file.php/10602/A_importancia_do_ensino_da_literatura_hoje. /yatsuda_e_haquira.pdf > Acesso em: 28 set. 2010.

FRONTALINI, D. Documentacion contra la impunidad. Dossiê NEV. São Paulo; Buenos Aires: NEV; CELS, n. 7, 1991.

GADAMER, H. G. Poema y diálogo. In: Poema y dialogo. Barcelona: Gedisa, 1993. pp. 142-158.

GADAMER, H. G. Verdade e método I. 8. ed. Petrópolis, Bragança Paulista: Vozes, Ed. Univ. São Francisco, 2007a . 
GADAMER, H. G. Verdade e método II. 8. ed. Petrópolis, Bragança Paulista: Vozes, Ed. Univ. São Francisco, 2007b.

GRAVES, R. A Deusa branca: uma gramática histórica do mito poético. Rio de Janeiro: Bertrand Brasil, 2003.

GULLAR, F. Traduzir-se. In: . Na vertigem do dia. Rio de Janeiro: Jose Olympio, 2004. Disponível em: < http://www.revista.agulha.nom.br/gula.html\#traduzir/>. Acesso em: 20 out. 2010.

GULLAR, F. Em alguma parte alguma. Rio de Janeiro: José Olympio, 2010.

HANDKE, P. Song of childhood. [S. 1]: [S. n], 1987. Disponível em <http://www.wimwenders.com/movies/movies_spec/wingsofdesire/wod-song-of-childhood.htm $>$ Acesso em: 07 nov. 2010.

HEIDEGGER, M. Carta sobre o humanismo. São Paulo: Centauro, 2005.

HEIDEGGER, M. Being and time. New York: Harper Perennial Modern Thought, 2008a.

HEIDEGGER, M. Introdução à filosofia. São Paulo: Martins Fontes, 2008 b.

HEIDEGGER, M. Parmênides. Petrópolis: Vozes, 2008c.

HEIDEGGER, M. Ser e tempo. 3. ed. Petrópolis: Vozes, 2008d .

HEISENBERG, W. A Parte e o todo. Rio de Janeiro: Contraponto, 1996.

JAEGER, W. Paidéia: a formação do homem grego. São Paulo: Martins Fontes, 1986.

LAFER, C. A reconstrução dos direitos humanos: um diálogo com o pensamento de Hannah Arendt. São Paulo: Cia. Das Letras, 1988.

LAFER, C. Desafios: ética e política. São Paulo: Editora Siciliano, 1995.

LAFER, C. Notas de palestra sobre Hannah Arendt. Faculdade de Direito da Universidade de São Paulo, 2006. (manuscrito).

LAJOLO, M. Literatura: leitores e leitura. São Paulo: Moderna, 2001.

LISPECTOR, C. A descoberta do mundo. Rio de Janeiro: Rocco, 1999.

LLOSA, M. V. Discurso proferido ao receber o Prêmio Nobel de Literatura. Estocolmo, 2010.

MAMAN, J. A. Fenomenologia existencial do direito: crítica do pensamento jurídico brasileiro. 2 ed. São Paulo: Quartier Latin, 2003.

MARCUSE, H. Eros e civilização: uma interpretação filosófica do pensamento de Freud. Rio de Janeiro: Zahar Editores, 1968. 
MARX, K. A questão judaica. [S. 1.]: Lusosofia, 1975. Disponível em:

$<$ http://www.lusosofia.net/textos/marx_questao_judaica.pdf $>$. Acesso em: 04 abr. 2009.

MATOS, O. C. F. Democracia midiática e república cultural. In: Discretas esperanças: reflexões filosóficas sobre o mundo contemporâneo. São Paulo: Nova Alexandria, 2006. pp. 7-34.

MORSINK, J. The universal declaration of human rights: origins, drafting, and intent. Philadelphia: University of Pennsylvania Press, 1999.

NAÇÕES UNIDAS. Declaração Universal dos Direitos Humanos. 10 dez. 1948. Disponível em $<$ http://www.onu-brasil.org.br/documentos_direitoshumanos.php $>$ Acesso em: 14 nov. 2010.

NAÇÕES UNIDAS. Human Rights Council Advisory Committee. Recomendation 4/2: Draft United Nations declaration on human rights education and training. 29 jan. 2010. Disponível em:

$<$ http://www2.ohchr.org/english/bodies/hrcouncil/advisorycommittee/HR_education_traini ng.htm> Acesso em: 20 out. 2010.

NASCIMENTO, G.; MAIEROVITCH, W. F. 'No Brasil, não existe 'nem República, nem democracia, nem Estado de Direito’. Carta Capital, São Paulo, [S. n.], p.1, 08 jan. 2010. Disponível em: $<$ http://www.cartacapital.com.br/app/materia.jsp?a $=2 \& a 2=8 \& \mathrm{i}=5800>$. Acesso em: 11 jan. 2010.

NATALI, M. P. Além da literatura. Literatura e Sociedade, São Paulo, n. 9, p.30-43, 2006.

NIETZSCHE, F. O nascimento da tragédia ou helenismo e pessimismo. 2. ed. São Paulo: Companhia das Letras, 1992.

ORWELL, G. 1984. São Paulo: Companhia das Letras, 2009.

PERRONE-MOISÉS, C. Forgiveness and crimes against humanity: a dialogue between Hannah Arendt and Jacques Derrida. Hannaharendt.net, n. 2, p.1, 2006. Disponível em: $<$ http://hannaharendt.net/research/perroneII.html>. Acesso em: 13 dez. 2010.

PERRONE-MOISÉS, L. A criação do texto literário. In. . Flores da escrivaninha. São Paulo: Companhia das Letras, 2006a. pp. 100-110.

PERRONE-MOISÉS, L. Literatura para todos. Literatura e Sociedade, São Paulo, n. 9, p.16-29, 2006b.

PERRONE-MOISÉS, L. Saramago conseguiu a proeza de ser um grande romancista moderno. Folha de S. Paulo, São Paulo, 18 jun. 2010. p. 1. Disponível em:

$<$ http://www1.folha.uol.com.br/ilustrada/753390-saramago-conseguiu-a-proeza-de-ser-umgrande-romancista-moderno.shtml>. Acesso em: 04 jul. 2010.

PINHEIRO, M. R. Experiência Vital e Filosofia Platônica. 2004. 189 f. Tese (Doutorado) - Pontifícia Universidade Católica, Rio de Janeiro, 2004. Disponível em: $<$ http://www2.dbd.puc-rio.br/pergamum/tesesabertas/0016082_04_cap_02.pdf $>$. Acesso em: 19 dez. 2010. 
POPE, A. Eloisa and Abelard. In: Works. London: W. Bowyer for Bernard Lintott, 1717. Disponível em: $<$ http://rpo.library.utoronto.ca/poem/1630.html $>$. Acesso em: 13 dez. 2010.

RAMOS, G. Memórias do cárcere. Rio de Janeiro: José Olympio, 1953.

SABATO, E. El túnel. 3. ed. Buenos Aires: Booket, 2004.

SANTANDER, C. U. A Sociedade Civil nos processos de transição política em Brasil e Peru: Cronologia e Comparação. In: Estudos sobre Direitos Humanos, Sociedade e Democracia. São Paulo: Imprensa Oficial, 2008.

SARTRE, J-P. Que é a literatura? 3. ed. São Paulo: Ática, 2006.

SARTRE, J-P. O ser e o nada: ensaio de ontologia fenomenológica. Petrópolis: Vozes, 2008.

SOLON, A. Notas de aulas do curso Filosofia do Direito I da Faculdade de Direitos da Universidade de São Paulo. 2010. (manuscrito). 


\section{Bibliografia Consultada}

COMPARATO, F. K. Afirmação Histórica dos Direitos Humanos. São Paulo: Saraiva, 2005.

FISCHER, S. R. A History of Language. London: Reaktion Books, 1999.

PLATÃO. A República. 8. ed. Lisboa: Fundação Calouste Gulbenkian, 1996.

SARTRE, J-P. Esboço de uma teoria das emoções. Rio de Janeiro: Zahar, 1965.

TUCÍDIDES. História da Guerra do Peloponeso - Livro I. São Paulo: Martins Fontes, 2008 .

ALEXY, R. Teoría del discurso y derechos humanos. Universidad Externado de Colombia.

LAFER, C. Antonio Candido Um humanista. JL - Jornal de Letras, Artes e Idéias, Paço de Arcos, p. 36, 10 maio 2006.

LAFER, C. A atividade sem sossego. Folha de S. Paulo, São Paulo, 19 jul. 1998.

LLOSA, M. V. A verdade das mentiras. In: Arx, 2004. pp. 15-30.

A verdade das mentiras. São Paulo: 